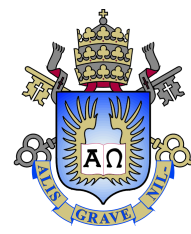

Mariana Vela Silveira

\title{
Análise do Comportamento Mecânico e da Durabilidade em Compósitos de Areia Reforçada com Fibras Naturais de Curauá e
}

Sisal

Tese de Doutorado

Tese apresentada como requisito parcial para obtenção do grau de Doutor pelo Programa de Pós-graduação em Engenharia Civil da PUC-Rio.

Orientadora : Profa ${ }^{2}$. Raquel Quadros Velloso

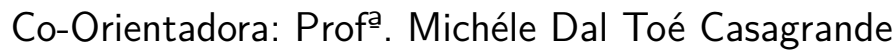




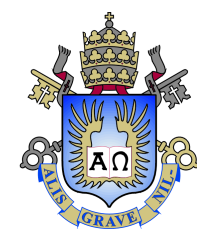

Mariana Vela Silveira

\title{
Análise do Comportamento Mecânico e da Durabilidade em Compósitos de Areia Reforçada com Fibras Naturais de Curauá e \\ Sisal
}

Tese apresentada como requisito parcial para obtenção do grau de Doutor pelo Programa de Pós-graduação em Engenharia Civil da PUC-Rio. Aprovada pela Comissão Examinadora abaixo assinada.

\author{
Profa. Raquel Quadros Velloso \\ Orientadora \\ Departamento de Engenharia Civil e Ambiental - PUC-Rio \\ Profa. Michéle Dal Toé Casagrande \\ Co-Orientadora \\ Universidade de Brasília - UnB \\ Prof. Celso Romanel \\ Departamento de Engenharia Civil e Ambiental - PUC-Rio
}

Prof ${ }^{a}$ Maria Isabel Pais da Silva Departamento de Química - PUC-Rio

Prof. Romildo Dias Toledo Filho Universidade Federal do Rio de Janeiro - UFRJ

Prof. Silvrano Adonias Dantas Neto Universidade Federal do Ceará - UFC

Prof. Márcio da Silveira Carvalho Coordenador Setorial do Centro Técnico Científico - PUC-Rio 
Todos os direitos reservados. É proibida a reprodução total ou parcial do trabalho sem autorização da universidade, do autor e do orientador.

\section{Mariana Vela Silveira}

Graduou-se em Engenharia Civil na Universidade Estadual Vale do Acaraú - UVA, em 2012. Obteve o título de mestre em Engenharia Civil - Geotecnia pela Universidade Federal do Ceará - UFC, em 2014. Principais áreas de interesse e linhas de pesquisas: Mecânica dos Solos, Geotecnia Experimental e Novos Materiais Geotécnicos

Ficha Catalográfica

Silveira, Mariana Vela

Análise do Comportamento Mecânico e da Durabilidade em Compósitos de Areia Reforçada com Fibras Naturais de Curauá e Sisal / Mariana Vela Silveira; orientadora: Raquel Quadros Velloso; co-orientadora: Michéle Dal Toé Casagrande. - Rio de janeiro: PUC-Rio, Departamento de Engenharia Civil e Ambiental, 2018.

v., 148 f: il. color. ; $30 \mathrm{~cm}$

Tese (doutorado) - Pontifícia Universidade Católica do Rio de Janeiro, Departamento de Engenharia Civil e Ambiental.

Inclui bibliografia

1. Geotecnia - Teses. 2. Engenharia Civil - Teses. 3. Solo Reforçado;. 4. Fibras Vegetais;. 5. Envelhecimento Natural;. 6. Degradação.. I. Velloso, Raquel Quadros. II. Casagrande, Michéle Dal Toé. III. Pontifícia Universidade Católica do Rio de Janeiro. Departamento de Engenharia Civil e Ambiental. IV. Título. 


\section{Agradecimentos}

Primeiramente agradeço a Deus, pela vida, pelas oportunidades, e pelas pessoas incríveis que me permitiu conhecer.

À minha família, minha base, meu porto-seguro. Em especial aos meus pais, Carlos e Cristina, e aos meus irmãos, Adriana e Renato, pelo apoio e amor incondicional. Eu amo vocês!

À minha orientadora Prof ${ }^{a}$. Michéle Casagrande, pela confiança, ensinamentos, e constantes incentivos. Obrigada por me guiar em todos os momentos, pela amizade, pela paciência e por me acalmar nos meus desesperos. Obrigada por ser "parceira até o fim", isso faz toda a diferença. Meu imenso obrigado!

Aos professores do Departamento de Engenharia Civil da PUC-Rio, por todo o conhecimento transmitido. Muito obrigada!

Aos membros da banca examinadora, pela disposição em avaliar e contribuir para a melhoria desta tese. Muito obrigada!

Ao Prof. Silvrano Dantas Neto, por ter me apoiado e incentivado a seguir o caminho do doutorado. Obrigada pela confiança!

À Prof ${ }^{\text {a }}$ Maria Isabel da Silva, pela disponibilização do Laboratório de Caracterização de Combustíveis, pela viabilização das análises químicas, e por estar sempre disposta a me ajudar e ensinar. Agradeço também à Gisele Barbosa, Laísa Azevedo e Henrique da Silva, por conduzirem as análises, pela paciência, atenção e amizade. Muito obrigada!

Ao Prof. Romildo Toledo Filho, pela disponibilização do Laboratório de Estruturas e Materiais Prof. Lobo Carneiro e viabilização dos trabalhos experimentais. Ao Saulo Ferreira, Tina Fidelis, Renata Santos e à Rosangela Leonardo, pela orientação, ensinamentos, pelas imagens incríveis de MEV e por toda atenção com que sempre me receberam. Muito obrigada!

Impossível realizar um trabalho experimental sem a ajuda dos funcionários dos Laboratórios: Amauri, Carlos (Geotecnia), Edson, Josué, Euclides, Rogério, Carlos (Estruturas), José Nilson e Marques. Aproveito para agradecer à Sandra e à Guaraciara, por alegrarem os meus dias no laboratório. Muito obrigada!

Ao Yuri Nascimento do Laboratório de Microscopia Eletrônica do Departamento de Engenharia Química dos Materiais, pelas incríveis imagens de MEV 
e pela paciência quando eu não sabia ao certo o que é que eu estava procurando. Muito obrigada!

À Thais Abreu, pela disposição em realizar as muitas análises de pH. Muito obrigada!

Ao Jean Santarelli, pela ajuda e empolgação em realizar a caracterização mineralógica da areia trabalhada. Muito obrigada!

Aos alunos de iniciação científica da Prof $^{a}$. Michéle e aos estagiários do Laboratório de Geotecnia, pela ajuda durante o desenvolvimento deste trabalho, em especial: Amanda, Bianca, João Pedro e Pedro. Muito obrigada!

Aos funcionários do Departamento de Engenharia Civil: Rita, Marcel, Fátima, Lenilson e Rafael. Muito obrigada!

A todos os amigos que fiz na PUC-Rio, em especial: Natália Tavares, Fernanda Bernardina, Juan Sotomayor, Adriano Malko, Arthur Amaral, Mieka Arao, Manoela Neves, Nathalia Louzada, Natalia Durán, Ana Maria Valverde, e Gabrielle Assumpção, pelas risadas, companheirismo e apoio.

À minha amiga Sheila, que me permitiu fazer de sua casa meu lar no Rio. Muito obrigada pelo carinho, conversas, incentivo, preocupação, ensinamentos, enfim, por tudo! Agradeço também a todos que por ali passaram... muitas histórias, muitos aprendizados.

Aos amigos que fiz no Rio de Janeiro, em especial à Família CEAK, pela amizade e carinho.

Aos amigos de longa data desta minha vida de nômade, que mesmo longe estão sempre presentes. Amo vocês!

Ao CNPq, pela concessão da bolsa de estudo. À PUC-Rio, por ter possibilitado a realização desta pesquisa.

Por fim, agradeço a todos que, de alguma forma, contribuíram em minha formação. 


\section{Resumo}

Silveira, Mariana Vela; Velloso, Raquel Quadros; Casagrande, Michéle Dal Toé. Análise do Comportamento Mecânico e da Durabilidade em Compósitos de Areia Reforçada com Fibras Naturais de Curauá e Sisal. Rio de Janeiro, 2018. 148p. Tese de Doutorado - Departamento de Engenharia Civil e Ambiental, Pontifícia Universidade Católica do Rio de Janeiro.

O presente trabalho tem como objetivo estudar o comportamento e a durabilidade de solos reforçados com fibras de vegetais (sisal e curauá) aleatoriamente distribuídas, submetidos ao envelhecimento natural por exposição às condições ambientais diversas, visando mostrar o seu potencial de utilização em obras de terra. O programa experimental consistiu na realização de ensaios triaxiais convencionais em amostras de areia e areiafibras no tempo zero (de controle) e em compósitos expostos aos agentes do ambiente externo por até 8 meses. Visando melhorar a durabilidade desses compósitos, foi avaliado também o comportamento mecânico destes com as fibras vegetais tratadas por impermeabilização superficial, com sílica coloidal e com polímero estireno butadieno. Para buscar explicar a variação nos resultados obtidos, ensaios de tração direta, microscopia eletrônica de varredura, espectroscopia na região do infravermelho e análise de perda de massa foram realizados nas fibras após cada período de exposição $(0,60,120$ e 240 dias). A análise global dos resultados permitiu identificar que os efeitos do envelhecimento natural afetaram consideravelmente o comportamento mecânico das fibras vegetais, o que consequentemente vieram a afetar o comportamento mecânico dos compósitos areia-fibra vegetal. As perdas de resistência ao cisalhamento foram mais relevantes e acentuadas nos compósitos com fibras de curauá, indicando que estas fibras, mesmo apresentando maior resistência à tração sem exposição, são mais susceptíveis à degradação em ambientes naturais do que as fibras de sisal. O tratamento superficial das fibras por impregnação com sílica coloidal resultou em melhorias no comportamento mecânico deste compósito, proporcionando também uma maior vida útil das fibras com relação à degradação. Mesmo com a perda do comportamento mecânico das fibras, após 8 meses de exposição aos agentes climáticos, estas continuaram contribuindo como elemento de reforço na matriz arenosa, visto que um dos parâmetros de resistência permaneceu maior quando comparado ao solo arenoso sem reforço.

\section{Palavras-chave}

Solo Reforçado; Fibras Vegetais; Envelhecimento Natural; Degradação. 


\section{Abstract}

Silveira, Mariana Vela; Velloso, Raquel Quadros (Advisor); Casagrande, Michéle Dal Toé (Co-Advisor). Mechanical Behavior and Durability Analysis of Reinforced Sand Composites with Curauá and Sisal Natural Fibers. Rio de Janeiro, 2018. 148p. Tese de doutorado - Departamento de Engenharia Civil e Ambiental, Pontifícia Universidade Católica do Rio de Janeiro.

The objective of this work is to study the behavior and durability of soils reinforced with randomly distributed vegetal fibers (sisal and curauá) submitted to natural aging by their exposure to diverse environmental conditions, aiming to boost its use in earthworks. The experimental program consisted of conventional triaxial tests on sand and sand-fibers samples at zero time (sample control) and on composites exposed to agents from the external environment for up to 8 months. In order to improve the durability of these composites, it was also evaluated the mechanical behavior of these with vegetal fibers treated by surface waterproofing, with colloidal silica and styrene butadiene polymer. In order to explain the variation in the obtained results, direct tensile tests, scanning electron microscopy, infrared spectroscopy and mass loss analysis were performed on the fibers after each exposure period (0, 60, 120 and 240 days). The overall analysis of the results allowed to identify that the effects of natural aging had a significant effect on the mechanical behavior of the vegetable fibers, which consequently affected the mechanical behavior of the sand-fiber composites. Shear strength losses were more relevant and accentuated in composites with curauá fibers, indicating that these fibers, even with higher tensile strength without exposure, are more susceptible to degradation in natural environments than sisal fibers. Surface treatment of the fibers by impregnation with colloidal silica resulted in improvements in the mechanical behavior of this composite, also providing a longer fiber life with respect to degradation. Even with the loss of mechanical behavior of the fibers, after 8 months of exposure to the climatic agents, they continued to contribute as a reinforcing element in the sandy matrix, since one of the resistance parameters remained higher when compared to the sandy soil without reinforcement.

\section{Keywords}

Reinforced Soil; Vegetal fibers; Natural Aging; Degradation. 


\section{Sumário}

$\begin{array}{lll}1 & \text { Introdução } & 17\end{array}$

$\begin{array}{lll}1.1 & \text { Relevância e justificativa da pesquisa } & 17\end{array}$

$\begin{array}{lll}1.2 & \text { Objetivos } & 18\end{array}$

$\begin{array}{lll}1.3 & \text { Organização da tese } & 19\end{array}$

2 Revisão bibliográfica $\quad 21$

2.1 Solos reforçados $\quad 21$

2.1.1 Histórico, melhoria, estabilização e reforço de solos 21

2.2 Fibras como reforço de solos 23

2.2.1 Alterações nas propriedades dos solos pela inclusão de fibras 24

2.2.1.1 Compactação 24

2.2.1.2 Resistência ao cisalhamento de pico 26

2.2.1.3 Resistência ao cisalhamento pós-pico 28

2.2.1.4 Comportamento carga-recalque 28

2.2.1.5 Propagação de fissuras 29

2.2.1.6 Deformabilidade 30

2.2.1.7 Modo de ruptura 30

2.2.1.8 Variação volumétrica 31

2.2.1.9 Rigidez inicial 32

2.2.1.10 Condutividade hidráulica e outras propriedades 32

2.2.2 Influência dos principais fatores no comportamento de solos reforçados 33

2.2.2.1 Comprimento da fibra (L) 34

2.2.2.2 Diâmetro da fibra (D) 35

$\begin{array}{lll}2.2 .2 .3 & \text { Fator de forma (L/D) } & 35\end{array}$

2.2.2.4 Teor de fibra 36

2.2.2.5 Orientação das fibras 36

2.2.2.6 Módulo de elasticidade da fibra 37

$\begin{array}{ll}\text { 2.2.2.7 Aderência fibra-matriz } & 37\end{array}$

$\begin{array}{lll}2.2 .2 .8 & \text { Resistência da fibra } & 38\end{array}$

2.2.2.9 Tensão confinante 38

2.2.2.10 Densidade relativa (Dr) 38

2.2.2.11 Diâmetro das partículas do solo 39

$\begin{array}{lll}2.3 & \text { Fibras vegetais } & 39\end{array}$

2.3.1 Fibra de Curauá (Ananas erectifolius) 41

2.3.2 Fibra de Sisal (Agave Sisalana) 44

2.3.3 Influência dos principais fatores no comportamento mecânico das fibras vegetais 46

2.3.3.1 Diâmetro da fibra (D) 47

2.3.3.2 Comprimento da fibra (L) 47

2.3.3.3 Ângulo microfibrilar 47

$\begin{array}{ll}\text { 2.3.3.4 Estrutura da fibra } & 48\end{array}$

2.3.3.5 Índice de cristalinidade 48

2.4 Reforço de solos com fibras vegetais 48

2.5 Durabilidade das fibras vegetais - estudos experimentais 49 
3 Caracterização do solo (matriz do compósito) 58

3.1 Materiais e métodos $\quad 58$

3.1.1 Solo arenoso 58

$\begin{array}{lll}3.1 .2 & \text { Caracterização física } & 59\end{array}$

3.1.3 Caracterização química $\quad 59$

$\begin{array}{lll}3.1 .4 & \text { Caracterização mineralógica } & 59\end{array}$

3.1.5 Caracterização mecânica 60

3.1.5.1 A prensa triaxial 60

3.1.5.2 Parâmetros de moldagem dos corpos de prova 61

3.1.5.3 Preparo das amostras para o ensaio triaxial 62

3.1.5.4 Ensaio triaxial convencional $\quad 62$

3.2 Apresentação e análise dos resultados de caracterização do solo 64

3.2.1 Caracterização física 64

3.2.2 Caracterização química 65

3.2.3 Caracterização mineralógica 66

3.2.4 Caracterização mecânica 66

4 Caracterização das fibras vegetais (elemento de reforço do compósito) $\quad 69$

4.1 Materiais e métodos $\quad 69$

4.1.1 Fibras de sisal e curauá $\quad 69$

4.1.2 Tratamentos por impregnação $\quad 71$

$\begin{array}{ll}\text { 4.1.3 Capacidade de absorção em água } & 72\end{array}$

$\begin{array}{lll}\text { 4.1.4 Análise microestrutural } & 73\end{array}$

4.1.5 Espectroscopia no Infravermelho por Transformada de Fourier (FTIR) 73

4.1.6 Espectrometria de Fluorescência de Raios-X (FRX) 73

4.1.7 Ensaio de Difração de Raios-X (DRX)

4.1.8 Ensaio de tração direta 74

4.2 Apresentação e análise dos resultados de caracterização dos reforços estudados 74

4.2.1 Tratamentos por impregnação $\quad 75$

4.2.2 Capacidade de absorção em água $\quad 75$

4.2.3 Análise microestrutural 76

4.2.4 Espectroscopia no Infravermelho por Transformada de Fourier (FTIR) 78

4.2.5 Espectrometria de Fluorescência de Raios-X (FRX) 81

4.2.6 Ensaio de Difração de Raios-X (DRX) 81

4.2.7 Ensaio de tração direta 82

5 Caracterização mecânica dos compósitos sem exposição $\quad 86$

5.1 Materiais e métodos $\quad 86$

5.1.1 Materiais 86

5.1.2 Moldagem das amostras de compósito solo-fibra 86

5.2 Apresentação e avaliação dos resultados $\quad 87$

5.2.1 Compósitos sem o tratamento das fibras $\quad 87$

5.2.2 Compósitos com o tratamento das fibras 91

6 Durabilidade das fibras submetidas ao envelhecimento natural $\quad 97$

6.1 Materiais e Métodos 97

6.1.1 Moldagem das amostras de compósito solo-fibra expostas às condições ambientais ao longo do tempo 
6.1.2 Preparo das amostras expostas às condições ambientais ao longo do tempo para ensaios e análises

6.2 Apresentação e análise dos resultados de caracterização dos reforços expostos

6.2.1 Aspecto dos compósitos expostos ao envelhecimento natural 101

$\begin{array}{ll}6.2 .2 \mathrm{pH} & 102\end{array}$

$\begin{array}{ll}\text { 6.2.3 Perda de massa das fibras } & 103\end{array}$

6.2.4 Análise microestrutural 106

6.2.5 Espectroscopia no Infravermelho por Transformada de Fourier (FTIR) 109

6.2.6 Espectrometria de Fluorescência de Raios-X (FRX) 110

6.2.7 Ensaio de tração direta 110

6.2.8 Micrografias de varredura em compósito exposto ao tempo 113

7 Durabilidade dos compósitos submetidos ao envelhecimento natural $\quad 115$

7.1 Materiais e métodos 115

7.1.1 Moldagem das amostras de compósito expostas as condições ambientais ao longo do tempo para o ensaio triaxial $\quad 115$

7.2 Apresentação e avaliação dos resultados 116

7.2.1 Compósitos expostos sem o tratamento das fibras 116

7.2.2 Compósitos expostos com as fibras tratadas superficialmente 123

8 Conclusões 134

8.1 Sugestões para trabalhos futuros 136

9 Referências bibliográficas $\quad 138$ 


\section{Lista de figuras}

Figura 2.1 Estrutura hierárquica de uma fibra de sisal (Melo Filho, 2012).

Figura 2.2 Plantação e fruto de curauá (Santiago, 2011; Pinto, 2007) 42

Figura 2.3 Plantação de sisal (Santiago, 2011) 44

Figura 3.1 Solo arenoso utilizado como matriz do compósito 58

Figura 3.2 Equipamento triaxial 61

Figura 3.3 Moldagem do corpo de prova no equipamento triaxial 62

Figura 3.4 Curva granulométrica da areia de Itaboraí 65

Figura 3.5 Aspecto macroscópico da amostra de solo: (a) fração retida na peneira $n^{\circ} 40$ e (b) fração de areia passante na peneira de $n^{\circ} 40$ e retida na peneira de $n^{\circ} 200$.

$\begin{array}{lll}\text { Figura 3.6 Resultado dos ensaios triaxiais do solo arenoso } & 67\end{array}$

$\begin{array}{lll}\text { Figura 4.1 Fibras vegetais de Sisal e Curauá } & 70\end{array}$

Figura 4.2 Estrutura molecular do estireno butadieno carboxilado (XSBR)

Figura 4.3 Ganho de massa das fibras vegetais com e sem tratamento em água

Figura 4.4 Morfologia da seção transversal e superfície das fibras vegetais sem tratamento: (a) sisal e b) curauá

Figura 4.5 Morfologia da seção transversal e superfície das fibras vegetais tratadas superficialmente: (a) sisal-sílica, (b) sisalpolímero, (c) curauá-sílica e (d) curauá-polímero

Figura 4.6 Espectro FTIR das fibras vegetais com e sem tratamento 80

$\begin{array}{lll}\text { Figura 4.7 } & \text { Difratogramas das fibras de sisal e curauá. } & 82\end{array}$

Figura 4.8 Representação gráfica dos 15 resultados dos ensaios de tração e média calculada para as fibras vegetais sem exposição:

(a) sisal e (b) curauá

Figura 4.9 Representação gráfica dos resultados dos ensaios de tração e média calculada para as fibras vegetais tratadas superficialmente: (a) sisal-sílica, (b) sisal-polímero, (c) curauá-sílica e (d) curauá-polímero

Figura 5.1 Resultados dos ensaios triaxiais convencionais nas amostras de controle

Figura 5.2 Resultados dos ensaios triaxiais convencionais nos compósitos de areia reforçada com fibras de sisal tratadas com sílica e polímero

Figura 5.3 Resultados dos ensaios triaxiais convencionais nos compósitos de areia reforçada com fibras de curauá tratadas com sílica e polímero

Figura 6.1 Local escolhido para expor as amostras aos agentes climáticos 
Figura 6.2 Moldagem das amostras de compósito solo-fibra expostas às condições ambientais

Figura 6.3 Parâmetros meteorológicos do ano de 2017: temperatura média, umidade relativa média do ar e precipitação

Figura 6.4 Preparo das amostras expostas para as análises de durabilidade

Figura 6.5 Amostras de solo reforçados com fibras expostos às condições climáticas ao longo do tempo: (a), (b) e (c) sisal 2, 4 e 8 meses, respectivamente e (d), (e) e (f) Curauá 2, 4 e 8 meses, respectivamente.

Figura 6.6 pH dos compósitos expostos ao tempo

Figura 6.7 Massa remanescente das fibras expostas ao solo, aos agentes climáticos e ao tempo

Figura 6.8 Morfologia da seção transversal e superfície das fibras vegetais sem tratamento ao longo do tempo: (a), (b) e (c) sisal 2, 4 e 8 meses, respectivamente e (d), (e) e (f) curauá 2, 4 e 8 meses, respectivamente.

Figura 6.9 Morfologia da seção transversal e superfície das fibras vegetais tratadas após 8 meses de exposição: (a) sisal-sílica, (b)sisal-polímero, (c) curauá-sílica e (d) curauá-polímero

Figura 6.10 Espectros FTIR das fibras vegetais sem tratamento expostas ao envelhecimento natural

Figura 6.11 Representação gráfica dos resultados e média calculada das fibras vegetais após exposicao ao clima: (a), (b) e (c) sisal nos tempos 2, 4 e 8 meses, respectivamente e (d), (e) e (f) curauá nos tempos 2, 4 e 8 meses, respectivamente

Figura 6.12 Resistência à tração e capacidade de deformação das fibras vegetais sem tratamento expostas ao tempo

Figura 6.13 Imagens de varredura eletrônica realizadas no compósito areia-curauá exposto por 8 meses

Figura 7.1 Resultado dos ensaios triaxiais convencionais nos compósitos areia-sisal sem tratamento expostos ao intemperismo e ao tempo

Figura 7.2 Resultado dos ensaios triaxiais convencionais nos compósitos areia-curauá sem tratamento expostos ao intemperismo e ao tempo

Figura 7.3 Propriedades mecânicas da areia e dos compósitos areia-fibras vegetais sem tratamento expostos ao intemperismo: (a)Máxima tensão desviadora e (b)Capacidade de absorção de energia $\left(E_{d e f}\right)$

Figura 7.4 Parâmetros de resistência da areia e dos compósitos areia-fibras vegetais sem tratamento expostos ao intemperismo

Figura 7.5 Resultado dos ensaios triaxiais convencionais nos compósitos areia-sisal tratada com sílica expostos ao intemperismo e ao tempo

Figura 7.6 Resultado dos ensaios triaxiais convencionais nos compósitos areia-sisal tratada com polímero expostos ao intemperismo e ao tempo 
Figura 7.7 Propriedades mecânicas da areia e dos compósitos areiafibra de sisal tratada expostos ao intemperismo: (a) Máxima tensão desviadora e (b) Capacidade de absorção de energia $\left(E_{\text {def }}\right) 127$

Figura 7.8 Parâmetros de resistência da areia e dos compósitos areia-fibra de sisal tratada expostos ao intemperismo

Figura 7.9 Resultado dos ensaios triaxiais convencionais nos compósitos areia-curauá tratada com sílica expostos ao intemperismo e ao tempo

Figura 7.10 Resultado dos ensaios triaxiais convencionais nos compósitos areia-curauá tratada com polímero expostos ao intemperismo e ao tempo

Figura 7.11 Propriedades mecânicas da areia e dos compósitos areiafibra de curauá tratada expostos ao intemperismo: (a) Máxima tensão desviadora e (b) Capacidade de absorção de energia $\left(E_{\text {def }}\right) 132$

Figura 7.12 Parâmetros de resistência da areia e dos compósitos areia-fibra de curauá tratada expostos ao intemperismo 


\section{Lista de tabelas}

Tabela 2.1 Propriedades físicas da fibra de curauá 43

Tabela 2.2 Características de absorção de água da fibra de curauá 43

Tabela 2.3 Propriedades químicas da fibra de curauá 43

Tabela 2.4 Propriedades mecânicas da fibra de curauá 43

$\begin{array}{lll}\text { Tabela 2.5 } & \text { Propriedades físicas da fibra de sisal } & 46\end{array}$

Tabela 2.6 Características de absorção de água da fibra de sisal 46

Tabela 2.7 Propriedades químicas da fibra de sisal 46

Tabela 2.8 Propriedades mecânicas da fibra de sisal 46

Tabela 3.1 Índices físicos da areia de Itaboraí 65

Tabela 3.2 Composição química da areia de Itaboraí 66

Tabela 3.3 Índices físicos após o adensamento e no final do ensaio, dos corpos de prova de solo arenoso sem reforço 67

Tabela 3.4 Valores das propriedades mecânicas e dos parâmetros de resistência para a amostra de solo arenoso sem reforço 68

Tabela 4.1 Propriedades físicas e químicas dos tratamentos superfíciais estudados

Tabela 4.2 Consumo de solução e ganho de massa das fibras após tratamento 75

Tabela 4.3 Composição química das fibras vegetais com e sem tratamento

Tabela 4.4 Resultados médios e desvios-padrões dos ensaios de tração nas fibras vegetais sem tratamento superficial

Tabela 4.5 Resultados médios e desvios-padrões dos ensaios de tração nas fibras vegetais tratadas superficialmente

Tabela 5.1 Índices físicos após o adensamento e no final do ensaio, dos corpos de prova de compósitos areia-fibras vegetais sem tratamento no tempo zero

Tabela 5.2 Valores das propriedades mecânicas e dos parâmetros de resistência para os compósitos areia-fibras (amostra de controle) 90

Tabela 5.3 Índices físicos após o adensamento e no final do ensaio, dos corpos de prova de compósitos de areia reforçada com fibras de sisal tratadas com sílica e polímero

Tabela 5.4 Índices físicos após o adensamento e no final do ensaio, dos corpos de prova de compósitos de areia reforçada com fibras de curauá tratadas com sílica e polímero

Tabela 5.5 Valores das propriedades mecânicas e dos parâmetros de resistência para os compósitos areia-fibras tratadas no tempo zero 96

Tabela 6.1 Composição química das fibras vegetais sem tratamento após 8 meses de exposição 
Tabela 6.2 Resultados médios e desvios-padrões dos ensaios de tração nas fibras vegetais sem tratamento superficial expostas ao envelhecimento natural

Tabela 7.1 Índices físicos após o adensamento e no final do ensaio, dos corpos de prova de compósitos areia-sisal sem tratamento expostos ao intemperismo e ao tempo

Tabela 7.2 Valores das propriedades mecânicas e dos parâmetros de resistência para os compósitos areia-fibras vegetais sem tratamento expostos ao intemperismo

Tabela 7.3 Índices físicos após o adensamento e no final do ensaio, dos corpos de prova de compósitos areia-sisal tratada expostos ao intemperismo e ao tempo

Tabela 7.4 Valores das propriedades mecânicas e dos parâmetros de resistência para os compósitos areia-fibras de sisal tratadas expostos ao intemperismo.

Tabela 7.5 Índices físicos após o adensamento e no final do ensaio, dos corpos de prova de compósitos areia-sisal tratada expostos ao intemperismo e ao tempo

Tabela 7.6 Valores das propriedades mecânicas e dos parâmetros de resistência para os compósitos areia-fibras de curauá tratadas expostos ao intemperismo. 


\section{Lista de Abreviaturas}

ABNT - Associação Brasileira de Normas Técnicas

c' - Intercepto coesivo

$C_{c}$ - Coeficiente de curvatura

CID - Consolidado isotropicamente drenado

$C_{u}$ - Coeficiente de uniformidade

D - Diâmetro da fibra

$D_{10}$ - Diâmetro efetivo

$D_{50}$ - Diâmetro médio

Dr - Densidade relativa

DRX - Difração de Raios-X

$\mathrm{e}$ - Índice de vazios

$e_{\max }$ - Índice de vazios máximo

$e_{\text {min }}$ - Índice de vazios mínimo

$\varepsilon_{a}-$ Deformação axial

$E_{d e f}$ - Capacidade de absorção de energia deformação ou tenacidade

$\varepsilon_{v}$ - Deformação volumétrica

FRX - Fluorescência de Raios-X

FTIR - Espectroscopia na Região do Infravermelho

$G_{s}$ - Densidade real dos grãos

IC - Índice de cristalinidade

L - Comprimento da fibra

L/D - Fator de forma (relação entre o comprimento e o diâmetro da fibra)

MEV - Microscopia Eletrônica de Varredura

NBR - Norma Brasileira

p' - Tensão efetiva média $\left(\left(\sigma_{1}^{\prime}+2 . \sigma_{3}^{\prime}\right) / 3\right)$

$\mathrm{pH}$ - Potencial hidrogeniônico

$\phi^{\prime}$ - Ângulo de atrito interno

$q$ - Tensão desviadora $\left(\sigma_{1}^{\prime}-\sigma_{3}^{\prime}\right)$

$\mathrm{SP}$ - Areia mal graduada

SUCS - Sistema Unificado de Classificação de Solos

$\sigma_{1}$ e $\sigma_{3}-$ Tensão principal maior e menor

XSBR - Copolímero de butadieno e estireno modificado com ácido carboxílico 


\section{Introdução}

\section{1}

\section{Relevância e justificativa da pesquisa}

A técnica de empregar fibras como reforço de materiais de construção para melhorar suas propriedades mecânicas é, há muito tempo, conhecida e empregada pela humanidade. No entanto, apenas a partir da segunda metade do século XX é que os princípios relativos ao seu uso começaram a ser compreendidos.

Amplamente pesquisado, é consenso que o melhoramento ou alteração das propriedades mecânicas dos solos reforçados com fibras depende das características das fibras, do solo, da tensão de confinamento e do modo de carregamento, e que o maior potencial dos materiais compósitos fibrosos está no estado pós-pico, onde as fibras contribuem de forma mais efetiva na resistência do material, aumentando assim a sua capacidade de absorção de energia.

A maioria dos reforços e produtos afins que são utilizados em aplicações de engenharia são realizados a partir de materiais sintéticos. No entanto, devido aos problemas de eliminação de resíduos e ao esgotamento dos recursos petroquímicos aliados à uma maior conscientização ambiental por parte da sociedade buscou-se alternativas sustentáveis motivando o desenvolvimento de materiais compósitos reforçados por fibras de origem vegetal.

As fibras vegetais, comparadas às fibras sintéticas, são de baixo custo, de fácil obtenção, fartamente disponíveis, mais fáceis de manusear, têm boas propriedades mecânicas, não geram quantidades excessivas de resíduos, empregam tecnologias relativamente simples e requerem menos energia no processo de produção, além de serem de fontes renováveis (Dittenber \& GangaRao, 2012).

No entanto, as fibras vegetais, comparadas às fibras sintéticas apresentam grande variabilidade das propriedades físicas e mecânicas (cerca de 40\%), susceptibilidade de degradação em ambientes naturais e variações dimensionais por mudanças de teor de umidade e/ou temperatura (Ghavami et al., 1999). Estes pontos são apontados como motivos de recusa para o emprego destas fibras como elemento de reforço em obras de terra. 
Porém, há em engenharia geotécnica um significativo número de situações onde o caso crítico para a estabilização ou funcionalidade da obra é imediatamente após a construção, como uma estrada de acesso construído sobre argila mole saturada, onde a função primária de qualquer reforço é permitir que a estrada seja construída. Para estes casos, as fibras vegetais podem ser usadas se a variação temporal das funções e características necessárias para superar um determinado problema for identificada e em seguida fabricar o produto em conformidade.

Embora a importância de avaliar a durabilidade das fibras vegetais tenha sido reconhecida, não foi encontrado na literatura nenhum estudo que tenha avaliado o comportamento mecânico do compósito solo-fibras vegetais aleatoriamente distribuídas após exposição aos agentes climáticos diversos e ao tempo, principalmente em climas tropicais.

Muitos foram os estudos encontrados que avaliavam a durabilidade das fibras vegetais, nas mais diferentes matrizes e nos mais diversos tipos de condições de envelhecimento, mas sempre o elemento de reforço é analisado isoladamente.

A durabilidade de compósitos cimentícios reforçados com fibras vegetais vem sendo amplamente pesquisada. Nestes estudos é consenso que o meio alcalino da matriz, proporcionado pelos produtos de hidratação do cimento, é prejudicial às fibras afetando, consequentemente, a durabilidade do compósito. Este tipo de ataque às fibras vegetais não seria o mesmo que aconteceria em uma matriz de solo.

Neste contexto, o presente trabalho busca contribuir para uma melhor interpretação e compreensão do comportamento do solo reforçado com fibras vegetais aleatoriamente distribuídas, podendo potencializar o uso de misturas solo-fibra vegetal em obras de terra.

\section{2}

\section{Objetivos}

O objetivo principal desta pesquisa consiste em estudar o comportamento mecânico e a durabilidade de solos reforçados com fibras vegetais de sisal e curauá aleatoriamente distribuídas expostos aos agentes climáticos diversos e à passagem do tempo.

Este objetivo será alcançado através da avaliação do comportamento tensão vs deformação das misturas com e sem exposição ao envelhecimento natural, estabelecendo padrões de comportamento que possam explicar a influência da adição de fibras, relacionando-a com os parâmetros de resistência ao cisalhamento e deformação do solo. 
A partir do objetivo geral, os seguintes objetivos específicos foram estabelecidos:

- Estudar as propriedades físico-químicas e mecânicas das fibras vegetais de sisal e curauá com e sem tratamento de impermeabilização superficial com sílica coloidal e com copolímero de butadieno e estireno carboxilado no tempo zero, ou seja, sem contato com o solo e os agentes climáticos;

- Avaliar a influência da adição de fibras vegetais com e sem tratamento superficial no comportamento mecânico de um solo arenoso através da realização de ensaios triaxiais drenados, com carregamento axial a taxa de deformação constante;

- Verificar a influência da exposição ao solo, aos agentes climáticos e ao tempo (8 meses) nas propriedades físico-químicas e mecânicas das fibras vegetais de sisal e curauá com e sem tratamento de impermeabilização superficial;

- Avaliar os efeitos de 60, 120 e 240 dias de envelhecimento natural no comportamento tensão vs deformação de um solo arenoso reforçado com fibras vegetais com e sem tratamento superficial, através da realização de ensaios triaxiais drenados, com carregamento axial e taxa de deformação constante.

\section{3}

\section{Organização da tese}

Para o melhor entendimento deste trabalho, o mesmo é apresentado em oito capítulos, incluindo esta introdução, sendo descritos a seguir, resumidamente, o conteúdo de cada um deles.

O Capítulo 2 abrange uma revisão bibliográfica sobre os temas relacionados ao objetivo da pesquisa, dando uma noção básica sobre solos reforçados, fibras vegetais, bem como seu comportamento mecânico e durabilidade de compósitos solo-fibras vegetais.

No Capítulo 3 são apresentados e analisados os resultados dos ensaios de caraterização geotécnica e do ensaio triaxial convencional executados no solo adotado como matriz do compósito.

O Capítulo 4 apresenta a caracterização química, mecânica e morfológica das fibras de sisal e curauá com e sem tratamento superficial com sílica e polímero.

No Capítulo 5 é apresentada a caracterização mecânica dos compósitos de solo reforçados com fibras vegetais com e sem tratamento superficial sem exposição aos agentes climáticos diversos e ao tempo. 
O Capítulo 6 apresenta o estudo da durabilidade química, mecânica e morfológica das fibras de sisal e curauá com e sem tratamento superficial com sílica e polímero expostas à matriz arenosa e agentes climáticos por 8 (oito) meses.

No Capítulo 7 são apresentados e analisados os resultados dos ensaios triaxiais convencionais executados nos compósitos solo-fibras vegetais com e sem tratamento submetidos a 8 meses de envelhecimento natural.

No Capítulo 8 são apresentadas as principais conclusões e sugestões para futuros trabalhos.

No final da tese encontram-se as Referências Bibliográficas 


\section{2}

\section{Revisão bibliográfica}

\section{1}

\section{Solos reforçados}

Entende-se por melhoria ou reforço de solos a utilização de processos físicos e/ou químicos que visem o melhoramento das propriedades mecânicas dos solos. Procura-se o aumento da resistência do solo tratado e a diminuição de sua compressibilidade e de sua permeabilidade. O termo melhoria de solos está associado ao tratamento através de processos químicos, enquanto que o termo reforço está associado à utilização de inclusões em aterros ou taludes (Casagrande, 2005).

Opta-se pelo uso do processo de reforço quando o solo do local da obra de construção civil não apresenta as propriedades geotécnicas exigidas pelo projeto, possibilitando melhorar determinadas propriedades, dispensando assim, os custos provenientes de distâncias de transporte elevadas das jazidas com material adequado e bota fora (Pessoa, 2004).

\subsection{1}

\section{Histórico, melhoria, estabilização e reforço de solos}

A técnica de melhorar as propriedades mecânicas dos solos é há muito tempo conhecida e empregada pela humanidade (Palmeira, 1992). Segundo Van Impe (1989), do ponto de vista técnico, o melhoramento do solo é, provavelmente, a técnica mais antiga, comparando os métodos executivos comuns em Engenharia Civil.

Desde a antiguidade, o homem entendeu que há um sentido de praticidade em utilizar o solo existente no local em que se constrói, mesmo que as características deste não sejam as melhores. Assim, para aperfeiçoar suas características, começou a realizar a adição de diferentes materiais, em sua maioria orgânicos, a fim de conseguir uma estrutura resistente e durável, ao longo do tempo (Sotomayor, 2014).

Fruto dessa necessidade, abundantes técnicas de melhoramento das características do solo e de seu comportamento foram desenvolvidas pelo homem. 
Existem registros de materiais vegetais serem usados para dar maior resistência aos tijolos de argila que datam de eras antes de Cristo (Palmeira, 1992).

Outros indícios são apresentados por Silva (2009), onde por volta de 5.000 a 2.500 anos atrás, durante a construção de grandes templos religiosos, como o Ziggurats, pelos babilônios, eram utilizadas esteiras de cana como elementos de reforço. Em alguns Ziggurats, utilizavam-se como reforço adicional cordas com $0.05 \mathrm{~m}$ de diâmetro, inseridas perpendicularmente ao talude e regularmente espaçadas nas direções vertical e horizontal.

Em algumas das estradas que conectavam o Império Romano, foram encontrados vestígios de tecidos e peles utilizadas para propósitos de reforço. Indícios do emprego dessa técnica são, ainda, encontrados em partes da Grande Muralha da China (Sotomayor, 2014).

No Peru, os incas construíram as estradas no Palácio do Sol e da Lua reforçadas com misturas de lã de lhama e argila. Muralhas de adobe reforçadas com bambu podem ser encontradas na cidade histórica de ChanChan, existentes há mais de 600 anos, feitas pela civilização anterior aos incas, numa zona de grande atividade sísmica (Sotomayor, 2014).

Entretanto, a técnica do reforço de solos com fibras, nos moldes que se tem hoje, foi resgatada na segunda metade do século XX. Diversos artigos foram publicados com o intuito de avaliar o efeito de raízes de plantas na resistência ao cisalhamento dos solos. Kaul (1965), Endo \& Tsuruta (1969), Gray \& Ohashi (1983) evidenciaram a contribuição positiva de raízes de plantas para a resistência ao cisalhamento dos solos além de comprovarem que estas contribuíam também para a estabilidade dos taludes.

Baseando-se nos princípios de reforço que as raízes de plantas introduziam ao solo, foram desenvolvidas técnicas que atuassem da mesma maneira. Vidal (1969) patenteou a técnica denominada "Terra Armada", na qual o reforço foi alcançado através da introdução de tiras metálicas e painéis de concreto que constituíam a face do maciço.

Atualmente, reforços em forma de tiras de aço, telas metálicas e vários tipos de materiais sintéticos têm sido amplamente utilizados na construção de obras geotécnicas. Tais aplicações vão desde as estruturas convencionais à estabilização de aterros sobre solos moles, passando por reforços de taludes, aumento da capacidade de suporte de fundações e reforço de pavimentos. Obras executadas a partir de solos reforçados apresentam inúmeras vantagens técnicas, construtivas e econômicas, quando comparadas aos métodos tradicionais, contribuindo, desta forma, para o grande aumento de sua utilização em diversos tipos de obra (Palacios, 2012).

Segundo Chen (2010), solos reforçados com fibras estão atualmente sendo 
usados ou considerados para aplicações que incluem estabilização de rupturas de taludes, construção de novos aterros com solos marginais, redução das fissuras de contração em liners de argila compactadas, e para reforçar subbases rodoviárias. Hejazi et al. (2012) mostra que o uso de fibras naturais e/ou sintéticas em engenharia geotécnica é viável em seis campos, incluindo camadas de pavimento (construção de estradas), muros de contenção, aterros ferroviários, proteção de encostas, engenharia sísmica e fundação de solos.

\section{2}

\section{Fibras como reforço de solos}

A técnica de reforçar solos com fibras encontra-se inserida na tecnologia dos materiais compósitos. Segundo Budinski (1996), um material compósito é a combinação de dois ou mais materiais que possue propriedade que os materiais componentes não possuem por si próprios. Portanto, estes são constituídos por uma fase chamada matriz (solo, concreto, silicone, argamassa, etc.) e pelo elemento de reforço (fibras, papéis, aço, fragmentos de borracha, isopor, etc.), sendo que ambos são desenvolvidos para otimizar (ou complementar) as características inerentes de cada um destes dois componentes.

Um grande número de novos materiais tem sido desenvolvido atualmente, geralmente baseado em materiais tradicionais, mas incorporando de alguma forma elementos de reforço. Para tanto é necessário que se conheçam as propriedades mecânicas, físicas e químicas dos materiais de constituição e como eles podem ser combinados (Palacios, 2012).

Existe ampla variedade de fibras disponíveis no mercado para serem empregadas como reforço de solos. Segundo o material de origem da fibras elas podem ser minerais (carbono, vidro e amianto), vegetais (coco, sisal, curauá, juta, piassava, pupunha, etc.), poliméricas (polipropileno, polietileno, poliéster e poliamida), e metálicas (aço).

As características de comportamento de cada uma delas, as propriedades físicas, químicas e mecânicas, que por sua vez irão afetar o comportamento do material compósito, estão intimamente relacionadas ao material do qual são compostas e ao seu processo de fabricação.

Portanto, a compreensão do mecanismo de interação matriz-reforço e da parcela de contribuição de cada uma das fases no comportamento do material compósito como um todo é fundamental para a definição do tipo de fibra a ser empregado. Esta definição dependerá fundamentalmente das características da matriz a ser reforçada e das características desejadas do material compósito resultante. 


\subsection{1}

\section{Alterações nas propriedades dos solos pela inclusão de fibras}

A maioria dos estudos realizados em materiais compósitos concentraram seus esforços em comparar o comportamento de solos reforçados com o de solos não reforçados através dos respectivos parâmetros de resistência ou deformabilidade.

Como são inúmeras as combinações de variáveis que alteram de forma significativa os mecanismos de interação, é possível afirmar que existe uma grande complexidade nos fatores que afetam o comportamento do compósito solo-fibra. Para uma dada combinação de variáveis, o resultado obtido pode ser o desejado para uma dada aplicação do compósito, porém, pode não ser para outra. Conhecendo-se as mudanças na estrutura do material reforçado com fibras em relação ao solo sem fibras tem-se base para avaliar até que ponto o comportamento mecânico dos solos reforçados pode ser explicado pelas mudanças nos parâmetros usuais empregados para solos não reforçados (Casagrande, 2005).

As características almejadas com a inclusão de fibras vão depender do tipo de aplicação do compósito, e não necessariamente serão de ganho de resistência. Em um projeto de material sismo-resistente, por exemplo, a ênfase será no aumento da capacidade de absorção de energia e ductilidade, assim como diminuição da queda de resistência pós-pico (Martins, 2014).

Diversos autores relataram em seus trabalhos algumas mudanças que ocorrem no comportamento mecânico dos solos reforçados com fibras. Estas mudanças são relacionadas à compactação, resistência ao cisalhamento, deformabilidade, modo de ruptura, variação volumétrica, rigidez inicial e condutividade hidráulica. Na sequência são descritas algumas alterações que ocorrem no solo devido à inclusão de fibras.

\subsubsection{1}

\section{Compactação}

Hoare (1979) estudou a influência da adição de fibras de polipropileno na compactação de um cascalho com areia. Observou que as fibras conferem certa resistência à compactação, resultando em porosidades maiores da mistura para as mesmas energias de compactação, sendo este um aumento linear em relação à quantidade de fibra e independente do tipo de compactação empregada. Resultados de ensaios empregando-se dois tipos de reforços diferentes sugeriram ainda que a influência na compactação é comandada pela interação entre solo e reforço, atentando para aspectos como a granulometria do solo, forma das partículas, textura e área superficial do reforço. 
Pinto (2007) também observou que as amostras com adição de fibras vegetais necessitaram de um maior esforço para a compactação em comparação aos espécimes sem fibras, comprovando a atuação das fibras durante a confecção dos corpos de prova, indicando que as fibras atuam durante a compactação absorvendo parte da energia imposta.

Al Wahab \& Al-Qurna (1995) avaliaram os efeitos da inclusão de vários teores de fibra na curva de compactação de uma argila. Os resultados encontrados demonstraram um decréscimo da massa específica aparente seca máxima e um acréscimo na umidade ótima para a adição de $2 \%$ de fibra, considerados não muito significativos.

Tal comportamento de aumento da umidade e diminuição da massa específica aparente seca máxima quando fibras vegetais são adicionadas ao solo também foi constatado por Prabakar \& Sridhar (2002), Mirzababaei et al. (2013) e Sarbaz et al. (2014). Mirzababaei et al. (2013) atribui a diminuição do peso específico seco máximo à diferença entre a densidade das partículas do solo em comparação com a das fibras.

Já Leocádio (2005) observou que o aumento do teor de fibras vegetais adicionado ao solo aumentou a massa específica aparente seca máxima até certo limite e depois a diminuiu mantendo o valor próximo ao do solo natural e, evidenciou também o aumento da umidade ótima.

Bueno et al. (1996) observaram o mesmo comportamento com relação à umidade para um solo arenoso, ao contrário do solo argiloso, onde não foi observada nenhuma alteração na umidade ótima. Em ambos os casos, a massa específica aparente seca máxima não sofreu alterações com a inclusão de fibras.

Vários outros autores relataram não ter encontrado nenhuma alteração significativa com a inclusão de fibras (Maher \& Ho, 1994; Nataraj et al., 1996; Ulbrich, 1997; Consoli et al., 1999; Casagrande, 2001; Heineck, 2002).

Diab et al. (2018) avaliou o efeito de dois métodos de compactação (de impacto e de amassamento) no comportamento mecânico não drenado de argilas reforçadas com fibras. Os resultados indicam que a melhoria na resistência é altamente dependente do método de compactação, com amostras preparadas usando compactação de impacto (método empregado em laboratório) produzindo melhorias até três vezes maiores do que amostras preparadas por amassamento (método empregado em campo). Essa discrepância no comportamento foi atribuída à diferenças nas distribuições de orientação das fibras entre as amostras que foram compactados por impacto e amassamento. 


\subsubsection{2}

\section{Resistência ao cisalhamento de pico}

Acréscimos na resistência ao cisalhamento de pico pela inclusão de fibras ao solo foram relatados por vários autores (e.g. Gray \& Ohashi, 1983; Maher \& Gray, 1990; Bueno et al., 1996; Michalowski \& Čermák, 2003; Heineck et al., 2005; Consoli et al., 2007; Ahmad et al., 2010; Jamei et al., 2013; Diambra \& Ibraim, 2015; Senez, 2016; Diab et al., 2018).

Plé et al. (2009) observaram que a adição de fibra aumenta a resistência ao cisalhamento do solo, mas dependendo do tipo de fibra o aumento será do ângulo de atrito ou da coesão. O aumento do ângulo de atrito e do intercepto coesivo com a inclusão de fibras e com o aumento do teor de fibras também foi relatado por diversos pesquisadores (e.g. Hoare, 1979; Gray \& Ohashi, 1983; Bueno et al., 1996; Nataraj et al., 1996; Stauffer \& Holtz, 1995).

Vários autores relataram apenas o aumento do intercepto coesivo com a inclusão de fibras (e.g. Bueno et al., 1996; Nataraj et al., 1996; Teodoro, 1999; Casagrande, 2001; Heineck, 2002; Prabakar \& Sridhar, 2002; Leocádio, 2005; Santiago, 2011; Bolaños, 2013). Porém, outros autores relataram apenas o aumento do ângulo de atrito com a inclusão de fibras (e.g. Andersland \& Kattak, 1979; Al Wahab \& Al-Qurna, 1995; Teodoro, 1999; Heineck, 2002).

Shewbridge \& Sitar (1990) concluíram que o aumento da resistência de um solo granular é função das propriedades da areia (graduação, tamanho e forma das partículas) e da fibra (teor, relação L/D e módulo). A resistência diminui com o aumento do tamanho médio e da esfericidade das partículas de areia, por outro lado, há um acréscimo da resistência com o aumento do coeficiente de uniformidade da areia, do teor de fibras, do módulo das fibras e da relação L/D.

Segundo Maher \& Ho (1994) a inclusão de fibras tem uma influência significativa nas propriedades mecânicas de argilas cauliníticas. Os autores constataram que o aumento do teor de fibras aumenta a resistência à tração e à compressão, porém, o aumento do comprimento das fibras diminui a contribuição destas para a resistência, tanto à compressão como à tração. Enquanto que Bueno et al. (1996) observaram que os solos coesivos são menos sensíveis ao aumento do comprimento das fibras. Análises baseadas em ensaios triaxiais revelaram um acréscimo no ângulo de atrito com a adição do reforço, sendo este maior quanto maior for o teor de fibras.

Taylor (1994) acredita que para haver um acréscimo de resistência préfissuração do compósito, é necessária a utilização de uma fibra mais rígida que a matriz, bem como a aderência do reforço com a matriz deve ser tal que impeça movimentos relativos entre as partes. 
Casagrande (2001) e Casagrande \& Consoli (2002) avaliaram o comportamento de areia siltosa reforçada com fibras de polipropileno. Seus resultados mostram que as fibras passaram a contribuir de forma mais significativa para o acréscimo da resistência a partir de $2.5 \%$ de deformação axial.

As fibras passam a exercer uma ação efetiva dentro da massa de solo quando esta é submetida a esforços externos, ou seja, quando sofre deformações. Os carregamentos externos de compressão ou alívio de tensões agem na massa de solo provocando deformações internas que acabam por transferir esforços para os elementos de reforço. As fibras ao serem submetidas a esforços de tração transferem esforços para o solo, provocando uma redistribuição de tensões e, portanto, de deformações na matriz de solo. Assim, o comportamento das fibras é comandado pelas características de deformabilidade do solo e pela distribuição dessas deformações McGown et al., 1978).

Para Heineck (2002) e Heineck et al. (2003), a taxa de deformação onde as fibras passam a contribuir de forma mais significativa para o acréscimo de resistência ao cisalhamento depende do tipo de matriz.

Segundo Casagrande (2005), a adição de fibras de polipropileno nas matrizes de areia e bentonita aumenta tanto os parâmetros de resistência ao cisalhamento de pico, como também a resistência pós-pico após grandes deslocamentos horizontais, sem quedas significativas de resistência pós-pico no caso da matriz arenosa. Para a matriz de alta plasticidade e altos índices de vazios, o acréscimo de resistência tende a reduzir com o aumento dos deslocamentos cisalhantes. Por outro lado, o efeito da inclusão de fibras foi mais evidente para baixas tensões efetivas médias iniciais, menores diâmetros, maiores comprimentos e maiores teores de fibras, sendo seu efeito mais pronunciado para misturas mais densas.

Heineck (2002) constatou uma bilinearidade na envoltória de ruptura de uma areia siltosa reforçada com fibras. A parte inicial da envoltória possui um intercepto coesivo praticamente inexistente e um ângulo de atrito que supera o dobro do valor correspondente ao solo sem reforço. Já na segunda parte da envoltória, acima da tensão confinante crítica, o ângulo de atrito é semelhante ao do solo sem reforço, entretanto, houve um acréscimo razoável do intercepto coesivo.

A bilinearidade foi também observada por vários autores (e.g. Gray \& Ohashi, 1983; Gray \& Al-Refai, 1986; Maher \& Gray, 1990; Stauffer \& Holtz, 1995; Teodoro, 1999; Casagrande, 2005). Teodoro \& Bueno (1998) e Teodoro (1999) concluíram que as envoltórias tendem à bilinearilidade à medida que o teor e o comprimento das fibras aumentam.

Feuerharmel (2000) concluiu que o comportamento resistente dos solos 
reforçados pode ser dividido em três etapas, uma inicial, onde o comportamento é controlado basicamente pela matriz de solo, uma etapa intermediária, na qual o comportamento do material compósito é comandado juntamente pela matriz e pelos elementos de reforço, e uma etapa final, onde o comportamento do material é comandado exclusivamente pelas fibras. Curcio (2008) complementa, o comportamento do material compósito parece ser inicialmente controlado unicamente pela matriz de solo, à medida que crescem as deformações, o comportamento passa a ser controlado pela matriz e pelas fibras.

\subsubsection{3}

\section{Resistência ao cisalhamento pós-pico}

Praticamente todos os trabalhos que analisaram o comportamento de solos reforçados em termos da resistência concluíram que a adição de fibras reduz a queda da resistência pós-pico (e.g. Gray \& Ohashi, 1983; Gray \& AlRefai, 1986; Fatani et al., 1991; Ranjan et al., 1996; Consoli et al., 1999; Donato et al., 2004; Leocádio, 2005; Casagrande, 2005; Festugato, 2008; Martins, 2014).

Andersland \& Kattak (1979), Ranjan et al. (1996), Feuerharmel (2000), Santoni et al. (2001), Casagrande \& Consoli (2002) e Santiago (2011) relataram um crescimento constante da resistência com o aumento da deformação axial, caracterizando um comportamento elasto-plástico de endurecimento.

Santoni et al. (2001) observou que este comportamento de endurecimento apenas ocorre para teores de fibras entre 0.6 e $1.0 \%$, ou seja, para taxas inferiores a $0.6 \%$ tal comportamento não foi verificado. Para Santiago (2011) existe um valor para o índice de forma da fibra a partir do qual o comportamento de endurecimento (hardening) passa a ser mais nítido.

Lirer et al. (2012) estudou o comportamento de uma areia com pedregulho misturada com fibras de polipropileno. Para grandes deformações, o comportamento resistente do material com reforço e sem reforço é similar, isto quer dizer que a adição das fibras na areia com pedregulhos não contribui positivamente na resistência do material quando ele sofre grandes deformações.

Segundo Vendruscolo (2003), as fibras possuem a capacidade de mobilizar resistência mesmo quando submetidas a grandes deformações.

\subsubsection{4}

\section{Comportamento carga-recalque}

Casagrande (2005) executou ensaios de provas de carga em placa sobre espessas camadas de areia compactada, reforçada e não reforçada com fibras. O comportamento carga-recalque do solo arenoso foi significativamente influ- 
enciado pela adição de fibras, aumentando a capacidade de suporte deste pela inibição da formação e propagação de possíveis bandas de cisalhamento.

Donato (2007) concluiu que o comportamento carga-recalque da areia e das areias reforçadas com fibras de polipropileno é similar no início do carregamento até o momento em que a mobilização das fibras inseridas na matriz se mostra mais efetiva, a partir de certo nível de recalque e carga aplicada.

Girardello (2010) avaliou o comportamento mecânico de uma areia não saturada, com e sem reforço de fibras de polipropileno, através de ensaios de placa em densidade relativa de $50 \%$ e $90 \%$. O melhor resultado foi obtido para o ensaio de placa realizado na maior densidade relativa. Quanto maior for a densidade da mistura, mais cedo as fibras começam a ser mobilizadas dentro da massa de solo, apresentando um melhor intertravamento entre as fibras e a matriz.

\subsubsection{5}

\section{Propagação de fissuras}

As fibras não impedem a formação de fissuras no compósito, mas são capazes de aumentar a resistência à tração, a deformação de ruptura e a tenacidade pelo controle da abertura e do espaçamento e com isso o controle da propagação das fissuras (Taylor, 1994). Hannant (1994) acredita que as fibras que atravessam as fissuras mantêm as interfaces das fissuras juntas, beneficiando as propriedades mecânicas no estado pós-fissuração pelo aumento da ductilidade.

Teodoro \& Bueno (1998) e Teodoro (1999) confeccionaram painéis com solo de matriz argilosa reforçados com fibras de polipropileno, com a finalidade de estudar o padrão de fissuramento deste material quando submetido a variações térmicas. Os autores concluíram que o efeito da inclusão de fibras nos painéis foi o de reduzir a dimensão das trincas sem, no entanto, evitar o fissuramento. As fibras não impedem a formação de fissuras porque elas apenas são mobilizadas após a deformação da matriz, mas impedem o aumento das dimensões das fissuras pelo intertravamento que proporcionam na matriz.

Segundo Curcio (2008), a adição de fibras de PET reciclado reduziu a magnitude das fissuras de tração de amostras de solo compactado. A adição de $1 \%$ de fibras, além de favorecer o acréscimo da tensão de tração máxima do solo, retarda a abertura de fissuras e reduz a magnitude das mesmas, sem alterar as propriedades desejáveis na compactação e sem influenciar negativamente a condutividade hidráulica do solo quando utilizadas sob tensão confinante.

Plé et al. (2009) avaliou o desempenho mecânico da adição de fibras 
como reforço em uma argila com três tipos de fibras: fibras orgânicas de sisal, fibras de polipropileno sintéticas e uma mistura fibra metálica/pneu em pó, com razão de forma igual a 300. As fissuras se formaram mais rápidas nas amostras com fibras do que em amostras sem fibras, mas a propagação das fissuras foi reduzida devido à presença das fibras, reduzindo os danos, evitando o aparecimento de uma banda de cisalhamento e aumentando a capacidade da argila de suportar carga ou a sobrecarga.

Em geral, as fibras inibem a amplitude das fissuras associadas à ruptura do compósito. Este fato leva a um aumento nas áreas sob as curvas tensão vs deformação. Esta propriedade é comumente referida como tenacidade, e representa o trabalho da fissuras ou a capacidade de absorção de energia do compósito (Casagrande, 2005)

\subsubsection{6 \\ Deformabilidade}

McGown et al. (1985) para areias e Maher \& Ho (1994) e Nataraj et al. (1996) para argilas, relataram um aumento no módulo de deformação, tanto maior quanto maior o teor de fibras. Contrariamente, Ulbrich (1997) e Consoli et al. (1999) obtiveram redução do módulo com a inclusão de fibras, para areias cimentadas e não cimentadas. A deformabilidade dos compósitos é dependente das características da matriz e do elemento de reforço.

Para Freitag (1986) as curvas tensão vs deformação mostraram que um solo residual de calcário compactado reforçado rompe em uma deformação bem superior à do solo não reforçado, sendo capaz de absorver maior energia de deformação.

Donato et al. (2004) avaliaram resultados de módulo de resiliência e verificaram a grande importância da inclusão de fibras sobre a deformabilidade resiliente, onde o módulo do compósito é reduzido em $65 \%$.

Consoli et al. (2007) observaram que quanto maior é o deslocamento cisalhante no ensaios, maior vai ser a quantidade de fibras rompidas, isto confere a ideia de que as fibras se alongam até que as deformações do ensaio superam a deformação de ruptura das fibras, porém as fibras sofrem deformações plásticas antes de romper.

\subsubsection{7}

\section{Modo de ruptura}

O aumento da ductilidade do solo com a adição de fibras é uma observação feita em caráter unânime pelos vários autores que avaliaram este parâmetro (e.g. Hoare, 1979; McGown et al., 1985; Maher \& Ho, 1994; Nataraj et al., 1996; 
Consoli et al., 1999; Ghavami et al., 1999; Casagrande, 2005; Martins, 2014), sendo este aumento mais pronunciado quanto maior for a quantidade de fibras.

Feuerharmel (2000) afirma que a forma de ruptura do solo é altamente alterada pela inclusão de fibras de polipropileno, reduzindo a fragilidade dos solos. A amplitude dessas alterações depende fundamentalmente de uma boa adesão solo-fibra, que pode ser atingida pela ação de um agente cimentante, formando uma estrutura cimentada bastante resistente ou por uma combinação apropriada dos fatores comprimento das fibras e tensões efetivas médias normais atuantes.

Donato et al. (2004) verificou uma mudança significativa quanto ao modo de ruptura, onde todas as amostras cimentadas não reforçadas estudadas exibiram um comportamento frágil na ruptura, enquanto que as amostras reforçadas com $0.5 \%$ de fibras de polipropileno apresentaram uma fragilidade menos pronunciada, mudando o comportamento de frágil para dúctil.

Consoli et al. (2004) concluiu que as fibras de polipropileno reduziram drasticamente o índice de fragilidade da areia cimentada, mudando o modo de ruptura de frágil para dúctil, para o maior comprimento de fibra estudado (36 $\mathrm{mm}$ ), com o aumento da capacidade de energia absorvida. Os autores reforçam que não é possível estabelecer regras de comportamento sem o conhecimento prévio das propriedades dos materiais envolvidos.

Mirzababaei et al. (2013) avaliou o efeito de dois tipos de fibras oriundas de resíduos de carpetes na resistência não confinada de dois solos argilosos. Os padrões de ruptura das amostras de solo não reforçadas são evidentes planos de cisalhamento quase verticais. Com um aumento no teor de fibra o padrão de ruptura é gradualmente transformado para um abaulamento plástico com redes de pequenas fissuras sem um plano de cisalhamento aparente na ruptura. As amostras de solo não reforçado mostram um comportamento frágil e rompem com uma deformação axial muito pequena (isto é, menos de 1\%), enquanto que amostras com $5 \%$ de teor de fibra rompem com uma deformação axial relativamente maior (isto é, $15 \%$ ou mais com comportamento de endurecimento e dúctil).

\subsubsection{8}

\section{Variação volumétrica}

Stauffer \& Holtz (1995) observaram que a adição de fibras aumenta as deformações volumétricas de compressão na ruptura, sendo este aumento mais pronunciado para uma areia uniforme do que para uma areia bem graduada, ambas com mesmo diâmetro médio $\left(D_{50}\right)$.

O aumento da compressibilidade do solo com a inclusão de fibras também 
foi observado por Bueno et al. (1996). Segundo Shewbridge \& Sitar (1990), a deformação volumétrica aumenta com o acréscimo da quantidade de reforço, porém, de forma não linear, similar ao observado por Nataraj et al. (1996).

Feuerharmel (2000) concluiu que as fibras constituem uma estrutura entrelaçada que impõe uma resistência às deformações radiais na amostra, aumentando assim as deformações de compressão do solo. Este efeito depende da adesão entre o solo e as fibras, sendo que para a areia, onde esta adesão é inferior aos demais solos, não se observa alterações significativas na variação volumétrica.

\subsubsection{9}

\section{Rigidez inicial}

Montardo (1999) observou uma queda bastante acentuada da rigidez inicial de uma areia cimentada reforçada com fibras de polipropileno. No entanto, as fibras de polietileno tereftalato e de vidro não causaram alteração alguma no módulo.

Michalowski \& Čermák (2003) observaram que a adição de uma fibra sintética em um solo arenoso causou uma queda da rigidez inicial, por outro lado, a adição de fibras de aço aumentou a rigidez inicial.

Feuerharmel (2000) concluiu que a adição de fibras de polipropileno provocou reduções no módulo de deformação inicial do solo, sendo que a intensidade das alterações depende do tipo e das características do solo, os solos menos rígidos foram os mais afetados enquanto que as alterações na areia foram pequenas.

Heineck (2002) realizou ensaios dinâmicos utilizando bender elements, seus resultados não indicaram alteração do G0 do solo arenoso quando da inclusão das fibras.

Assim, Plé et al. (2009) reforça que o efeito do reforço fibroso na rigidez inicial do compósito depende das características do mesmo.

Santiago (2011) observou que a adição de fibras e o aumento da tensão confinante aumentam o módulo de deformabilidade secante.

\subsubsection{0}

\section{Condutividade hidráulica e outras propriedades}

Maher \& Ho (1994) estudaram as propriedades hidráulicas de um compósito caulinita/fibra através de ensaios de condutividade hidráulica. Observou-se que a adição de reforços fibrosos aumentou a permeabilidade da argila estudada, sendo mais pronunciada para maiores teores de fibra. 
Al Wahab \& El-Kedrah (1995) observam um aumento da condutividade hidráulica em mais de uma ordem de grandeza para $2 \%$ de fibra (polipropileno).

Bueno et al. (1996) relataram uma redução da permeabilidade de uma ordem de grandeza, causada pela adição de fibras a solos granulares.

Segundo Heineck (2002) e Heineck et al. (2003), para todas as matrizes estudadas, a adição de $0.5 \%$ de fibras de polipropileno de $24 \mathrm{~mm}$ não causou mudanças significativas na condutividade hidráulica avaliada.

Nataraj et al. (1996) apresentaram os resultados de uma série de ensaios de laboratório em um solo arenoso e outro argiloso reforçados com fibras de polipropileno distribuídas aleatoriamente. Tanto o solo arenoso quanto o argiloso apresentaram valores de CBR maiores com a inclusão das fibras.

Al Wahab \& El-Kedrah (1995) observaram também a redução do potencial de retração e expansão em torno de 30 a 35\% com a adição de fibras, sendo este efeito mais pronunciado no ramo seco da curva de compactação e menos pronunciado no ramo úmido.

Leocádio (2005) também realizou ensaio CBR em amostras de solo reforçados com fibras vegetais. Observou que o valor do CBR aumentou com o aumento do teor e do comprimento até um certo valor e depois diminuiu. O aumento do teor de fibra aumentou a expansão significativamente, o que justifica a perda da capacidade de suporte.

Otoko et al. (2014) realizou ensaios de expansão onde as amostra de solo laterítico com e sem reforço de fibras vegetais ficaram submersas em água por 72 horas. Concluiu que a adição de fibras aumentou a variação de volume comparado com solo natural, e que a alteração de volume é diretamente proporcional ao teor de fibra adicionado. Os autores justificam este comportamento ao fato de que as fibras, pela sua alta capacidade de absorção, absorvem água e a conduzem para dentro da amostra como um tubo. Por esse motivo também, a adição de fibras iria aumentar significativamente a permeabilidade do solo. No entanto, na secagem, os benefícios da fibra é claramente observado nos resultados dos ensaios de compressão não-confinados, com o aumento na resistência à compressão, módulo de elasticidade e a deformação última que são todos diretamente proporcional ao aumento do teor de fibra.

\subsection{2}

\section{Influência dos principais fatores no comportamento de solos reforçados}

Em se tratando de compósitos fibrosos, fatores como o teor de fibra presente, o comprimento das fibras, características de resistência e deformabilidade do elemento de reforço, as características do solo e aderência entre matriz e 
reforço são determinantes para o desempenho do compósito já que isso implica na forma com a qual as fibras atuam controlando a abertura e o espaçamento entre as fissuras que se formam (Hannant,1994). Na sequencia são descritas as influências dos principais fatores no comportamento de solos reforçados.

\subsubsection{1}

\section{Comprimento da fibra (L)}

Gray \& Ohashi (1983), Ulbrich (1997), Santoni et al. (2001), Heineck (2002) e Vendruscolo (2003) observaram que aumento do comprimento das fibras resultou em um aumento da resistência, porém, esse aumento é verificado até certo limite, a partir do qual este efeito não é mais observado. Em outras palavras, existe um comprimento ótimo de fibra que confere a maior resistência.

Para Consoli et al. (2009a) fibras muito finas e longas têm problemas relacionados ao emaranhamento e eficácia reduzida

Consoli et al. (2007) estudaram o desempenho de uma areia reforçada com fibras de polipropileno de diferentes comprimentos submetida a grandes deformações cisalhantes mediante a execução de ensaios de ring shear. Os autores encontraram que, quanto maior for o comprimento das fibras de reforço, maior será o incremento da resistência cisalhante do solo.

Para Casagrande (2005) o aumento da resistência com o aumento do comprimento da fibra provavelmente ocorre devido ao fato das fibras de maior comprimento apresentarem uma ancoragem maior dentro da amostra.

Teodoro (1999) observou um aumento na resistência de uma areia siltosa reforçada com o aumento do comprimento das fibras de polipropileno de 0 para $30 \mathrm{~mm}$, comportamento este distinto do solo argiloso, que apresentou um máximo de resistência para fibras de $15 \mathrm{~mm}$.

Maher \& Ho (1994) observaram que para um mesmo teor de reforço, fibras mais curtas são mais numerosas dentro da matriz e existe uma maior possibilidade de elas estarem presentes na superfície de ruptura contribuindo para o aumento da resistência. Porém, após a ruptura, as fibras mais curtas são arrancadas mais facilmente, o que denota a importância de fibras mais longas quando se deseja melhorar a ductilidade e a capacidade de absorção de energia.

Segundo Ulbrich (1997) e Montardo et al. (2002), o aumento do comprimento da fibra provoca o aumento da capacidade de absorção de energia de deformação.

Segundo Vendrusculo (2003), o efeito do aumento do comprimento das fibras na rigidez inicial é nulo. 
Michalowski \& Čermák (2003) sugerem que o comprimento da fibra deve ser de pelo menos uma ordem de magnitude maior do que o tamanho do grão para que o mecanismo de interação fibra-solo seja acionado.

Casagrande (2005) analisou o comprimento final das fibras após ensaios de ring shear e observou que estas tendem a sofrer grandes deformações plásticas de tração, independente do comprimento inicial, sendo solicitadas sucessivamente após estágios de alongamento, em primeira instância, e consequente ruptura ao sofrerem deslocamentos maiores.

\subsubsection{2}

\section{Diâmetro da fibra (D)}

Para Vendruscolo (2003), o aumento do diâmetro (título) das fibras resulta em um decréscimo da tensão de ruptura. Isto ocorre porque com o aumento do título das fibras diminui a quantidade de fibras na matriz, já que se mantém sempre constante o peso de fibras que é adicionado ao material.

Segundo Casagrande (2005), as fibras de menor diâmetro proporcionam uma melhor interação solo-fibra e mobilização sucessiva destas, atuando positivamente na melhora do comportamento resistente do material.

\subsubsection{3}

\section{Fator de forma (L/D)}

Gray \& Maher (1989) verificaram a existência de uma tensão de confinamento crítica, onde o aumento da relação L/D resulta na redução desta tensão de confinamento crítica e torna mais efetivo a contribuição da fibra no aumento da resistência ao cisalhamento.

Gray \& Maher (1989), Michalowski \& Čermák (2003), Festugato (2008) e Ibraim et al. (2010) relatam que as fibras com alto fator de forma apresentam maior contribuição no aumento da resistência ao cisalhamento do que quando comparadas às fibras com menor razão de aspecto.

Festugato (2008) analisou o comportamento mecânico de um solo (areia fina) reforçado com fibras de polipropileno de distintos índices de forma. O autor conclui que os reforços proporcionam ao solo um comportamento de endurecimento (hardening), que passa a ser mais pronunciado a partir de um dado valor de índice de forma das fibras (em torno de 300).

Segundo Qu \& Sun (2016), um alto fator de forma contribui duplamente para o aumento da resistência ao cisalhamento do compósito. Quando o fator de forma é alto, o número absoluto de fibras (volume) é relativamente maior sob o mesmo teor de fibras, e a área de contato entre as fibras e as partículas do solo passa a ser alta também, produzindo atrito suficiente maior. 


\subsubsection{4}

\section{Teor de fibra}

Gray \& Ohashi (1983), Gray \& Al-Refai (1986), McGown et al. (1985), Maher \& Ho (1994), Specht (2000), Santoni et al. (2001), Vendruscolo (2003) e Consoli et al. (2007) verificaram que o aumento da resistência ao cisalhamento com o aumento do teor de fibra é observado até um certo limite. Em outras palavras, existe um teor ótimo de fibra que confere a melhor resistência.

Segundo Gray \& Ohashi (1983), Maher \& Ho (1994), Ulbrich (1997) e Montardo et al. (2002), o aumento do teor de fibra provoca aumento a capacidade de absorção de energia de deformação .

Segundo Vendrusculo (2003), o efeito do aumento do teor das fibras na rigidez inicial é nulo.

\subsubsection{5}

\section{Orientação das fibras}

Gray \& Ohashi (1983) avaliaram a orientação das fibras com relação à superfície de cisalhamento. Através da realização de ensaios de cisalhamento direto, observou-se que a inclinação de $60^{\circ}$ em relação ao plano de ruptura representa a maior contribuição em termos de resistência e a inclinação de $120^{\circ}$ representa a redução da resistência ao cisalhamento.

Para Johnston (1994), a orientação e distribuição das fibras na matriz tem grande influência. A orientação de uma fibra com respeito ao plano de ruptura implica nas possibilidades que esta tem de contribuir com a transferência de cargas. Uma fibra que se posiciona paralela ao plano de ruptura não tem efeito, por outro lado, uma fibra que se posiciona perpendicular a este plano contribui integralmente com sua capacidade de resistir à tração.

Segundo McGown et al. (1978), Fatani et al. (1991), Morel \& Gourc (1997) e Diambra et al. (2010), os elementos de reforço devem estar posicionados na direção das deformações de tração do solo

O emprego de fibras discretas aleatoriamente distribuídas possui duas grandes vantagens em relação aos solos reforçados com inclusões orientadas, contínuas ou não: minimiza o surgimento de qualquer tipo de anisotropia e não induz planos preferenciais de fraqueza (Gray \& Al-Refai, 1986; Gray \& Maher,1989; Maher \& Gray,1990). Tang et al. (2007) apontam outra vantagem, a simplicidade de incorporação das fibras na matriz, já que podem ser adicionadas da mesma maneira que o cimento, a cal e outros aditivos estabilizantes.

Ibraim et al. (2012) investigaram os efeitos dos procedimentos de fabricação de amostras reforçadas com fibras (moist tamping e moist vibration) 
na distribuição da orientação das fibras. A avaliação da distribuição da orientação das fibras das amostras reforçadas com três tipos diferentes de fibras de polipropileno mostrou que ambos os métodos deixam pelo menos $80 \%$ das fibras orientadas entre $\pm 30^{\circ}$ da horizontal. Os testes de compressão e extensão triaxiais mostraram que as fibras usadas neste estudo são notavelmente eficazes no aumento da resistência em compressão triaxial, enquanto sua contribuição em extensão é bastante limitada, se não desprezível. Tal observação indica um comportamento anisotrópico acentuado que suporta a distribuição anisotrópica da orientação da fibra que foi determinada.

\subsubsection{6}

\section{Módulo de elasticidade da fibra}

McGown et al. (1978) observaram que o comportamento tensão x deformação do solo reforçado depende fundamentalmente das características de resistência e deformabilidade dos elementos de reforço. Os autores propuseram a divisão do reforço de solos baseada na deformabilidade do reforço em inclusões extensíveis e não-extensíveis. O elemento de reforço extensível tem deformação de ruptura maior que a máxima deformação de tração do solo sem reforço. Sua principal função é de aumentar a ductilidade e diminuir a perda de resistência pós pico, além do acréscimo de resistência mecânica. Já o elemento de reforço não extensível tem deformação de ruptura menor que a máxima deformação de tração no solo sem reforço, conferindo ganho de resistência mecânica, porém, rupturas catastróficas podem ocorrer se o reforço romper.

Gray \& Ohashi (1983) e Specht (2000) observaram que as fibras com baixo módulo comportaram-se como uma inclusão extensível, ou seja, não romperam durante o ensaio. Para Montardo (1990) Specht (2000) fibras com módulo baixo não contribuem para o aumento da resistência mecânica

Segundo Shewbridge \& Sitar (1990) quanto maior o módulo maior a probabilidade de haver o arrancamento das fibras.

\subsubsection{7}

\section{Aderência fibra-matriz}

Para Taylor (1994), as fibras devem estar bem aderidas à matriz do compósito para que a sua resistência à tração seja mobilizada.

Segundo Casagrande (2005), as características de resistência, deformação e padrões de ruptura de uma grande variedade de compósitos reforçados com fibras dependem fundamentalmente da aderência fibra/matriz. Uma alta 
aderência entre a fibra e a matriz reduz o tamanho das fissuras e amplia sua distribuição pelo compósito.

\subsubsection{8}

\section{Resistência da fibra}

Para Casagrande (2005), o aumento da resistência das fibras aumenta a ductilidade do compósito, assumindo que não ocorra o rompimento das ligações de aderência. A resistência necessária dependerá, na prática, das características pós-fissuração necessárias, bem como do teor de fibra e das propriedades de aderência fibra-matriz.

\subsubsection{9}

\section{Tensão confinante}

Gray \& Ohashi (1983), Teodoro (1999), Morel \& Gourc (1997), Kaniraj \& Havanagi (2001), Heineck (2002) e Casagrande (2005) observaram a existência de uma tensão de confinamento crítica onde, abaixo desta as fibras são arrancadas e, acima desta as fibras são alongadas.

Para Gray \& Maher (1989) a tensão confinante crítica é sensível a alguns parâmetros do compósito solo-fibra como fator de forma das fibras (L/D), coeficiente de uniformidade e forma das partículas do solo.

Lirer (2012) estudou o comportamento de uma areia com pedregulho misturada com fibras de polipropileno e concluiu que a adição das fibras ao material apresenta maior influência em baixas tensões confinantes. Casagrande (2005) também concluiu que as fibras agem mais efetivamente sob tensões efetivas médias iniciais mais baixas.

\subsubsection{0}

\section{Densidade relativa (Dr)}

Consoli et al. (2009a) estudaram o efeito da densidade relativa da areia reforçada com fibras de polipropileno submetidas a ensaios de placa, concluindo que o efeito de inclusão das fibras pode ser mais pronunciado para densidades mais altas.

Segundo Casagrande (2005), quanto maior for a densidade da mistura, mais cedo as fibras começam a ser mobilizadas dentro da massa de solo, apresentando um melhor intertravamento entre as fibras e a matriz. Para densidades de compactação maiores existe um intertravamento inicial melhor entre a matriz e o reforço, o que permite que as fibras sejam solicitadas a deslocamentos muito pequenos. Para misturas solo-fibra com densidades 
menores as fibras passam a atuar após recalques iniciais de maior monta, devido à redução do índice de vazios e maximização dos contatos grãos-fibra.

\subsubsection{1}

\section{Diâmetro das partículas do solo}

Maher \& Gray (1990) realizaram estudo utilizando duas composições de bolas de vidro em lugar do solo, ambas com granulometria uniforme, porém diferentes diâmetros médios das partículas, mostrou que o aumento do tamanho das partículas $\left(D_{50}=0.25 \mathrm{~mm}\right.$ para $\left.0.6 \mathrm{~mm}\right)$ diminuiu a contribuição das fibras para a resistência.

\section{3}

\section{Fibras vegetais}

As fibras vegetais podem ser obtidas de diferentes partes da planta. Podem ser provenientes do caule, folha, sementes ou frutos das plantas. Fibras de juta, linho, cânhamo são exemplos de fibras obtidas do caule. As fibras de sisal, curauá e banana são provenientes da folha da planta. O algodão é um exemplo de fibra de sementes e a fibra de coco é proveniente do fruto (Thomas et al., 2011).

As fibras oriundas das folhas são as de maior interesse para serem utilizadas como reforço, embora fibras de talo, do caule e do fruto também possam ser usadas. De uma maneira geral, as fibras das folhas são mais grossas que as fibras dos talos e são referenciadas como fibras "duras" enquanto as fibras dos talos são chamadas de fibras "macias" e, portanto, mais próprias para fins têxteis (Santiago, 2011). Neste trabalho foram utilizados, dois tipos de fibras vegetais, fibras de curauá e sisal, ambas provenientes da folha das plantas.

De um modo geral, as fibras apresentam uma mesma estrutura celular como pode ser visto na Figura 2.1 (Fidelis et al., 2013). As fibras vegetais são, por si mesmas, materiais compósitos naturais por serem compostas por numerosas fibras individuais (fibrocélulas) unidas pelas lamelas médias. Cada fibrocélula é composta por quatro partes principais, a saber, a parede primária, a parede secundária, a parede terciária e o lúmen. (Silva et al., 2010; Fidelis et al., 2013; Ferreira et al., 2017).

Assim, as fibras vegetais são como tubos microscópicos, onde o lúmen está entre as paredes celulares (Thomas et al., 2011). Segundo Tolêdo Filho (1997), o lumen é a parte viva da célula, sendo responsável pela flexibilidade da fibra, pela elevada absorção de água e baixa massa específica aparente, características comuns às fibras vegetais. 


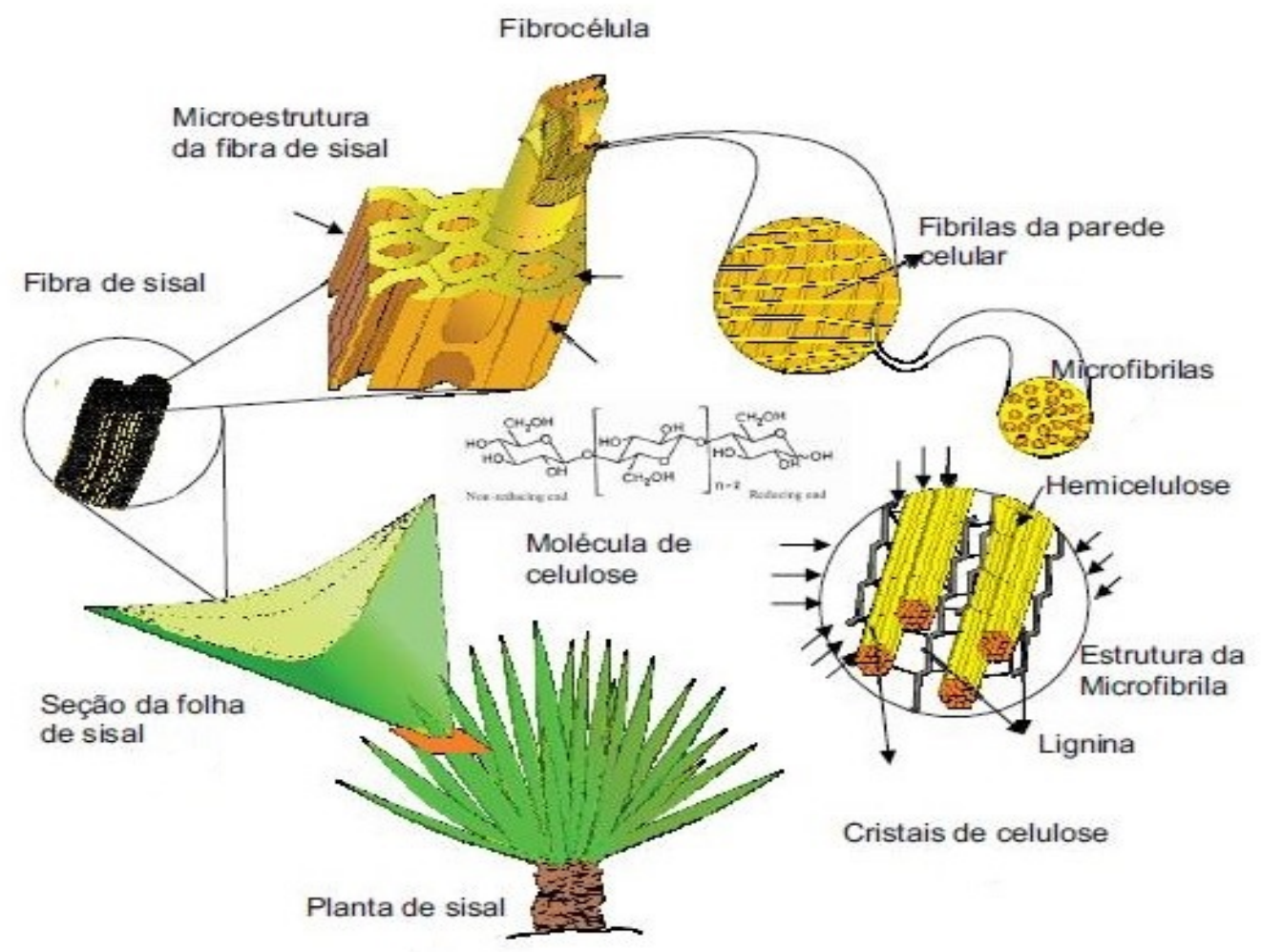

Figura 2.1: Estrutura hierárquica de uma fibra de sisal (Melo Filho, 2012).

Apesar de apresentarem uma mesma estrutura celular (paredes celulares, lamela média e lumens), as fibras vegetais se diferenciam por aspectos como a área transversal total, o número de fibrocélulas e espessura das paredes celulares, quantidade e área de lúmens. Esses fatores afetam a resistência mecânica das fibras (Fidelis et al., 2013).

As paredes celulares são constituídas por microfibrilas unidas por uma matriz de lignina e hemicelulose e apresentam diferentes orientações em cada parede celular. As microfibrilas possuem diâmetro de cerca de 10 - 30 nm e são constituídas por 30 - 100 moléculas de celulose (John \& Anandjiwala, 2008; Thomas et al., 2011; Dittenber \& GangaRao, 2012). O ângulo microfibrilar, ou ângulo médio, formado entre as microfibrilas e o eixo da fibra varia de uma fibra para outra e pode ser o responsável por propriedades mecânicas das fibras (Defoirdt et al., 2010). A parede secundária (a mais espessa) é a grande responsavel pelas propriedades mecânicas da fibra.

A composição química das fibras vegetais é apresentada minuciosamente por Tolêdo Filho (1997). De maneira resumida as fibras vegetais são formadas principalmente por celulose, hemicelulose, lignina e pectina.

A celulose é a principal componente da parede celular, em geral em estado cristalino (Tolêdo Filho, 1997). A celulose é um polímero linear de 
glicose com elevado grau de polimerização e alto índice de cristalinidade. É um polissacarídeo, composto por unidades de anidro-glicose, as quais contêm grupos de hidroxila que estabelecem interações por ligações de hidrogênio intra e intermolecular. Embora a estrutura química da celulose seja a mesma para diferentes fibras naturais, há variação no grau de polimerização, o qual afeta as propriedades mecânicas das fibras (Mohanty, 2005). O teor de celulose é o principal constituinte responsável pela resistência. A estrutura cristalina dos polímeros está relacionada à organização das cadeias poliméricas e afeta as propriedades mecânicas como rigidez e resistência. Quanto maior o grau de cristalinidade, melhor o alinhamento das cadeias e, portanto, maior a resistência (Canevarolo, 2006).

A hemicelulose também presente na parede celular, é raramente ou nunca cristalina (Tolêdo Filho, 1997). A hemicelulose é formada por um grupo de polissacarídeos, constituído de vários tipos de unidades de açúcares. Possui grande capacidade de absorção de água, devido entre outros fatores, à ausência de cristalinidade e à baixa massa molecular. A hemicelulose pouco contribui na resistência mecânica das fibras (Perissoto, 2005).

A lignina também presente na parede celular confere a esta resistência à compressão e rigidez (Tolêdo Filho, 1997). A lignina é um polímero amorfo constituído por unidades de fenilpropano, sendo uma de suas funções, juntamente com a hemicelulose, agir como barreira à degradação causada por microrganimos, além de conferir rigidez à fibra (Perissoto, 2005).

A pectina está presente na região de união entre células adjacentes, tornando as paredes celulares mais hidratadas e consequentemente mais plásticas (Tolêdo Filho, 1997). Como a lignina e a pectina são polímeros mais fracos que a celulose, os mesmos devem ser removidos quando as fibras são utilizadas como reforço em compósitos. Grande parte da pectina é removida quando os feixes são separados do caule através do processo de maceração (imersão) e espadelagem (Dittenber \& GangaRao, 2012).

Por serem naturais, a composição química e o percentual de cada componente variam de acordo com a espécie, a região da fibra onde é retirada a amostra, do estado de maturação, de fatores ambientais, como solo e clima, região de cultivo, entre outros (Perissoto, 2005). Segundo Canevarolo (2006) a composição química pode influir na resistência mecânica da fibra.

\subsection{1}

\section{Fibra de Curauá (Ananas erectifolius)}

As fibras de curauá, da espécie Ananas erectifolius, são fibras extraídas a partir das folhas da planta, que são bromeliáceas de ocorrência natural da 
Amazônia (Santiago, 2011). Esta planta (Figura 2.2) é da família do abacaxi (Ananás comosus), seu fruto é semelhante, em aspecto e sabor, ao abacaxi (Picanço, 2005). Embora comestível, o interesse econômico pelo curauá está primordialmente associado às fibras extraídas de suas folhas (Pinto, 2007).

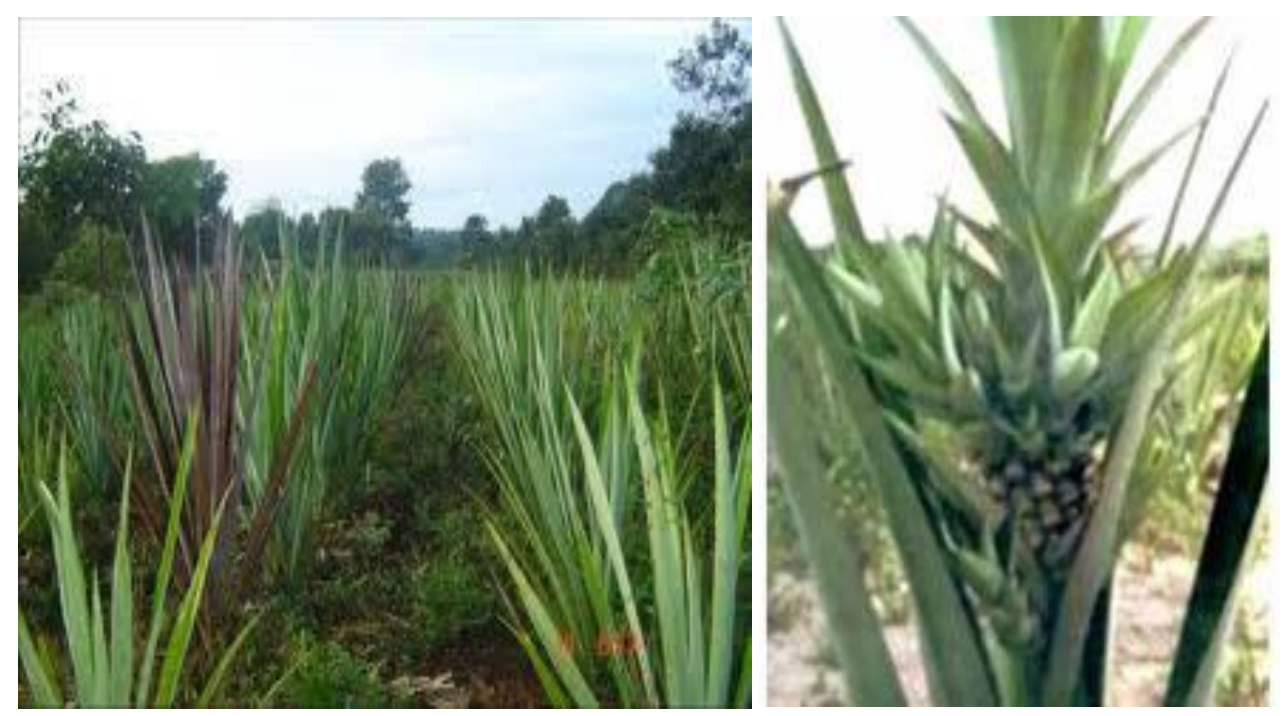

Figura 2.2: Plantação e fruto de curauá (Santiago, 2011; Pinto, 2007)

As folhas de curauá, que podem chegar a até 1.5 m de comprimento e 4 cm de largura, são duras, eretas e planas. As fibras extraídas das suas folhas têm alta resistência mecânica em comparação com outras fibras vegetais, como o sisal, juta e linho (Santiago, 2011).

Espécie nativa e rústica, o curauá não é exigente quanto ao solo, crescendo até em solo arenoso e pouco fértil inclusive em área degradadas. O cultivo da planta não provoca a degradação da mata nativa, contribui com a revitalização de terras desmatadas, não é exigente a fertilizantes químicos e pode ser consorciada com culturas alimentares, o que representa uma fonte alternativa de renda e garante também a segurança alimentar ao pequeno agricultor da região amazônica (Santiago, 2011).

Segundo Oliveira (2010), cada planta de curauá produz cerca de 24 folhas e o rendimento de fibra seca é de aproximadamente $6 \%$, totalizando quase 2 quilos de fibras por planta. Um hectare produz 3.600 quilos de fibra seca ao ano, embora esses valores variem bastante. Produtores colhem duas safras por ano do curauá nativo (Pinto, 2007).

O curauá está entre as fibras mais competitivas, figurando entre as mais economicamente viáveis (Santos, 2009). Devido as suas características, a fibra de curauá também vem despertando o interesse da indústria automobilística sendo usada como agente de reforço em painéis dianteiros, porta-pacotes, 
laterais de portas e porta-malas de veículos que integram o portfólio de gigantes do setor, como Volkswagen, Honda e General Motors (Santiago, 2011).

Apresentam-se a seguir valores, disponíveis na literatura, para as propriedades físicas (Tabela 2.1), absorção de água (Tabela 2.2), químicas (Tabela 2.3) e mecânicas (Tabela 2.4) das fibras de curauá.

Tabela 2.1: Propriedades físicas da fibra de curauá

\begin{tabular}{ccccc}
\hline $\begin{array}{c}\text { Diâmetro } \\
(\mathbf{m m})\end{array}$ & $\begin{array}{c}\text { Área } \\
\left(\mathbf{m m}^{\mathbf{2}}\right)\end{array}$ & $\begin{array}{c}\text { Densidade } \\
\left(\mathbf{g} / \mathbf{c m}^{\mathbf{3}}\right)\end{array}$ & $\begin{array}{c}\text { Cristalinidade } \\
\mathbf{( \% )}\end{array}$ & Referência \\
\hline- & 0.004 & - & 80.1 & Fidelis $(2014)$ \\
0.115 & - & 1.29 & - & Pinto $(2007)$ \\
0.09 & - & - & - & Santiago $(2011)$ \\
$0.092-0.127$ & - & 1.34 & - & Picanço $(2005)$ \\
\hline
\end{tabular}

Tabela 2.2: Características de absorção de água da fibra de curauá

\begin{tabular}{cccc}
\hline $\begin{array}{c}\text { Teor de } \\
\text { umidade natural } \\
(\boldsymbol{\%})\end{array}$ & $\begin{array}{c}\text { Absorção após } \\
\mathbf{5} \text { minutos } \\
(\boldsymbol{\%})\end{array}$ & $\begin{array}{c}\text { Absorção até } \\
\text { a saturação } \\
(\mathbf{\%})\end{array}$ & Referência \\
\hline 13.6 & 585.7 & 709.3 & Pinto (2007) \\
7.9 & - & - & Santiago (2011) \\
11.47 & - & 449 & Picanço (2005) \\
\hline
\end{tabular}

Tabela 2.3: Propriedades químicas da fibra de curauá

\begin{tabular}{ccccc}
\hline $\begin{array}{c}\text { Celulose } \\
(\mathbf{\%})\end{array}$ & $\begin{array}{c}\text { Hemicelulose } \\
\mathbf{( \% )}\end{array}$ & $\begin{array}{c}\text { Lignina } \\
\mathbf{( \% )}\end{array}$ & $\begin{array}{c}\text { Cinzas } \\
\mathbf{( \% )}\end{array}$ & Referência \\
\hline 59.4 & 19.1 & 14.4 & - & Fidelis $(2014)$ \\
71.2 & 12.1 & 7.4 & 0.9 & Santiago (2011) \\
58.8 & 23.8 & 14.7 & - & Ferreira $(2016)$ \\
\hline
\end{tabular}

Tabela 2.4: Propriedades mecânicas da fibra de curauá

\begin{tabular}{cccc}
\hline $\begin{array}{c}\text { Resistência } \\
\text { à tração } \\
(\mathbf{M P a})\end{array}$ & $\begin{array}{c}\text { Módulo de } \\
\text { Young } \\
(\mathbf{G P a})\end{array}$ & $\begin{array}{c}\text { Deformação } \\
\text { na ruptura } \\
\mathbf{( \% )}\end{array}$ & Referência \\
\hline 543.0 & 63.7 & 1.0 & Fidelis (2014) \\
492.6 & 11.5 & 3.0 & Picanço (2005) \\
605.0 & 23.0 & 2.5 & Santiago (2011) \\
\hline
\end{tabular}




\subsection{2}

\section{Fibra de Sisal (Agave Sisalana)}

A fibra de sisal, da espécie Agave sisalana e da família Agavaceae, é derivada da folha de uma planta (Figura 2.3) considerada indígena na América Central e do Sul (Costa, 2013).

Ghavami et al. (1999) explicam que o cultivo de sisal começou no México, antes da chegada dos europeus. A produção em maior escala ocorreu a partir de 1888, propagando-se do México para outras regiões tropicais e subtropicais.

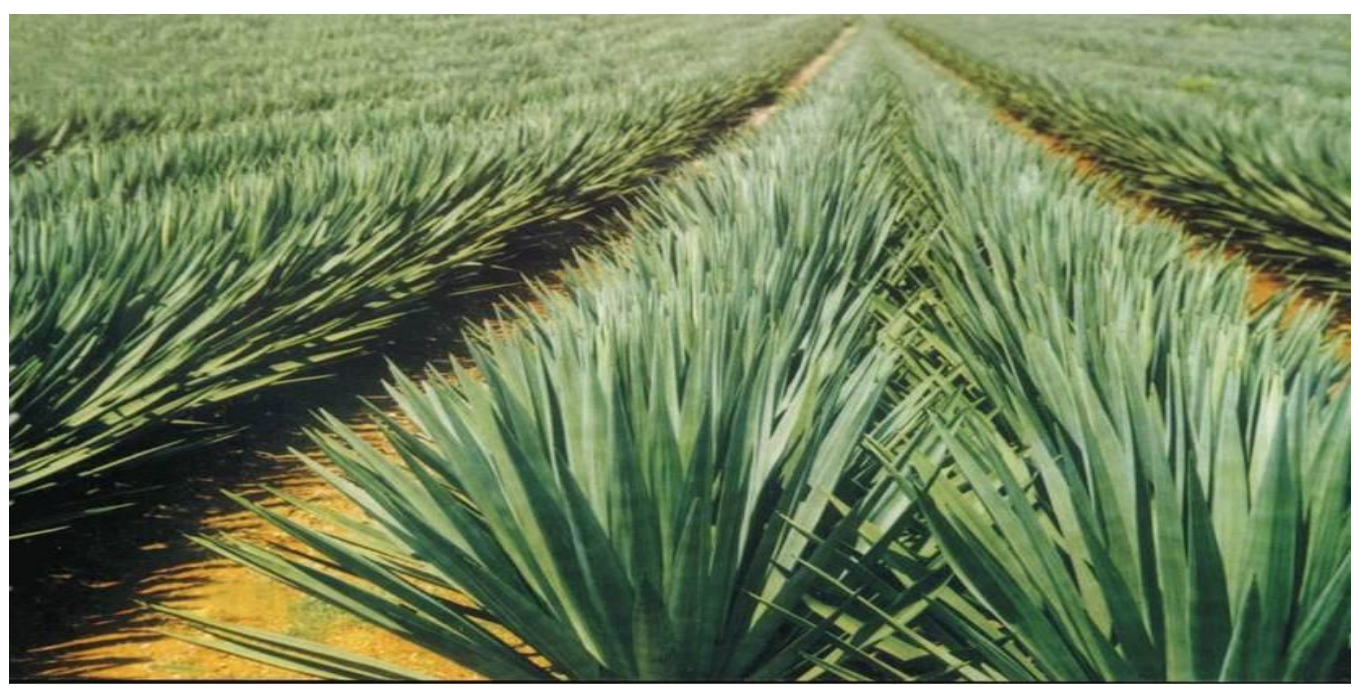

Figura 2.3: Plantação de sisal (Santiago, 2011)

Durante o final do século XVIII e início do século XIX, a plantação de sisal foi iniciada nos continentes africano e asiático, devido ao seu poder para crescer sob diferentes condições ecológicas e climáticas, variando desde as condições de calor e umidade do Quénia e Tanzânia, para as condições tropicais do Brasil, da costa da Florida e Havai e das ilhas das Caraíbas, e mais recentemente também a China se tornou um país produtor de sisal (Anandjiwala \& John, 2010).

Segundo Martins (2014), o Brasil juntamente com a Indonésia e países do leste africano, está entre os maiores produtores de sisal. A produção de sisal no Brasil concentra-se na região nordeste, sendo os estados da Bahia e Paraíba os maiores produtores.

A cultura do sisal, uma das fibras mais utilizadas mundialmente, é de extrema importância socioeconômica para o Brasil, por ser a única economicamente viável na região semiárida do Nordeste, com cerca de 1 milhão de pessoas que dela dependem para sua subsistência (Mattoso et al., 1997) 
Uma planta de sisal apresenta um período de vida que varia entre 7 e 15 anos, em função do tipo de cultura, espécie, clima, condições de crescimento e qualidade do solo (Anandjiwala \& John, 2010). A colheita do sisal é feita após 5 ou 6 anos do plantio. Essa colheita é executada inúmeras vezes durante o ano. As folhas apresentam coloração em tom cinza-esverdeado com largura entre 8 e $10 \mathrm{~cm}$ e comprimento entre 150 e $250 \mathrm{~cm}$. Uma planta de sisal pode chegar a produzir cerca de 200 folhas. As fibras encontram-se incrustadas no cerne das folhas. Uma folha normal pesa cerca de $600 \mathrm{~g}$, com as fibras a ocuparem cerca de $3 \%$ do seu peso, $81 \%$ é líquido (suco) e 15\% são os resíduos de desfibragem (adubo orgânico e ração animal), e com cada folha a ter cerca de 1.000 fibras (Joseph et al., 1999; Mattoso et al., 1997; Leocádio, 2005).

As fibras de sisal classificam-se no grupo de fibras chamadas "estruturais", cuja função é dar sustentação e rigidez as folhas. Elas se dispõem longitudinalmente ao longo do comprimento da folha. Compreendem três tipos: fibras mecânicas, fibras de fita e fibras de xilema. As fibras mecânicas estão presentes em maior número e dificilmente se dividem durante os processos de manufatura, o que lhes confere maior importância comercial (Leocádio, 2005).

Em 2000 eram produzidos 4.5 milhões de toneladas de fibras anualmente no mundo, sendo o Brasil um dos maiores produtores. Segundo Silva et al. (2008), uma máquina operada por dois homens pode beneficiar 6.000 folhas ao dia, cerca de 90 a $120 \mathrm{~kg}$ de fibras e que a produção anual de fibra de sisal é de 140.000 toneladas.

Depois da colheita, as fibras passam por um processo de desfibramento (raspagem mecânica) para remover a polpa que envolve a fibra. Em seguida são submetidas a processos de limpeza (lavagem, secagem e escovação) e enfardamento (de acordo com a qualidade e o comprimento). Os fardos são então comercializados para as indústrias que utilizam a fibra como matéria prima. Dentre as principais aplicações industriais do sisal destacam-se a produção de cordoalhas, barbantes, tapetes e estofamentos (Martins, 2014).

Segundo Leocádio (2005), o sisal é uma fibra leve, atóxica, que apresenta alto módulo e resistência e custa aproximadamente duas vezes menos que a fibra de vidro. Entre outras vantagens do sisal, é apontada a facilidade de modificação superficial, sua abundância no Brasil e facilidade de cultivo. A microestrutura helicoidal oca do sisal é responsável por um mecanismo de falha diferenciado de outras fibras vegetais, sendo que os compósitos reforçados por sisal apresentam trabalho de fratura similar ao de compósitos de polietileno de altíssimo peso molecular reforçado por fibras de vidro.

Apresentam-se a seguir valores, disponíveis na literatura, para as propriedades físicas (Tabela 2.5), absorção de água (Tabela 2.6), químicas (Tabela 2.7) 
e mecânicas (Tabela 2.8) das fibras de sisal.

Tabela 2.5: Propriedades físicas da fibra de sisal

\begin{tabular}{ccccc}
\hline $\begin{array}{c}\text { Diâmetro } \\
(\mathbf{m m})\end{array}$ & $\begin{array}{c}\text { Área } \\
\left(\mathbf{m m}^{2}\right)\end{array}$ & $\begin{array}{c}\text { Densidade } \\
\left(\mathrm{g} / \mathbf{c m}^{\mathbf{3}}\right)\end{array}$ & $\begin{array}{c}\text { Cristalinidade } \\
(\mathbf{\%})\end{array}$ & Referência \\
\hline $0.08-0.30$ & - & $0,75-1,07$ & - & Tolêdo Filho (1997) \\
0.15 & - & - & - & Santiago (2011) \\
0.228 & - & 1.13 & - & Pinto (2007) \\
0.174 & - & - & - & Martins (2014) \\
- & 0.023 & - & 76.3 & Fidelis (2014) \\
\hline
\end{tabular}

Tabela 2.6: Características de absorção de água da fibra de sisal

\begin{tabular}{cccc}
\hline $\begin{array}{c}\text { Teor de } \\
\text { umidade natural } \\
(\boldsymbol{\%})\end{array}$ & $\begin{array}{c}\text { Absorção após } \\
\mathbf{5} \text { minutos } \\
(\boldsymbol{\%})\end{array}$ & $\begin{array}{c}\text { Absorção até } \\
\text { saturação } \\
(\mathbf{\%})\end{array}$ & Referência \\
\hline $10.97-14.44$ & $67.0-92.0$ & $190-250$ & Tolêdo Filho (1997) \\
9.4 & - & - & Santiago (2011) \\
16.79 & 348.9 & 515.7 & Pinto (2007) \\
\hline
\end{tabular}

Tabela 2.7: Propriedades químicas da fibra de sisal

\begin{tabular}{ccccc}
\hline $\begin{array}{c}\text { Celulose } \\
(\boldsymbol{\%})\end{array}$ & $\begin{array}{c}\text { Hemicelulose } \\
(\boldsymbol{\%})\end{array}$ & $\begin{array}{c}\text { Lignina } \\
(\boldsymbol{\%})\end{array}$ & $\begin{array}{c}\text { Cinzas } \\
(\mathbf{\%})\end{array}$ & Referência \\
\hline 74.0 & 12.0 & 10.1 & 1.2 & Santiago $(2011)$ \\
59.5 & 18.4 & 11.9 & - & Fidelis $(2014)$ \\
60.5 & 25.7 & 12.1 & - & Ferreira $(2016)$ \\
\hline
\end{tabular}

Tabela 2.8: Propriedades mecânicas da fibra de sisal

\begin{tabular}{cccc}
\hline $\begin{array}{c}\text { Resistência } \\
\text { à tração } \\
(\mathbf{M P a})\end{array}$ & $\begin{array}{c}\text { Módulo de } \\
\text { Young } \\
(\mathbf{G P a})\end{array}$ & $\begin{array}{c}\text { Deformação } \\
\text { na ruptura } \\
\mathbf{( \% )}\end{array}$ & Referência \\
\hline $227.8-1002.3$ & $10.9-26.7$ & $2.8-4.2$ & Tolêdo Filho (1997) \\
340.0 & 12.0 & 3.3 & Santiago $(2011)$ \\
484.0 & 19.5 & 3.3 & Fidelis $(2014)$ \\
\hline
\end{tabular}

\subsection{3}

\section{Influência dos principais fatores no comportamento mecânico das fibras vegetais}

Diversos trabalhos foram realizados com várias fibras, a fim de se avaliar alguns fatores que influenciam no seu comportamento mecânico. Na sequência são descritas as influências dos principais fatores no comportamento mecânico das fibras vegetais. 


\subsubsection{1}

\section{Diâmetro da fibra (D)}

Tomczak et al. (2007) correlacionaram propriedades mecânicas de fibras de curauá com diâmetro, comprimento e taxa de deformação. Observaram que, para diferentes diâmetros $(0.026 \mathrm{~mm}-0.064 \mathrm{~mm})$, a resistência à tração e o módulo de elasticidade diminuíram com o aumento do diâmetro, de 310 para $131 \mathrm{MPa}$ e de 96.1 para 30.0 GPa, respectivamente.

\subsubsection{2}

\section{Comprimento da fibra (L)}

Para Tomczak et al. (2007), fibras de um mesmo diâmetro (0.046mm) e comprimentos variando entre 5 e $25 \mathrm{~mm}$, à medida em que houve aumento no comprimento, a resistência à tração diminuiu (223 para $173 \mathrm{MPa})$ e o módulo aumentou (26.6 para 52.9 GPa), o que pode ser explicado pelo aumento de falhas/defeitos na fibra com o aumento do comprimento. As fibras naturais têm irregularidades que podem ser associadas a defeitos e pontos fracos que podem afetar a resistência. Quanto maior o comprimento, maior a chance de ocorrerem falhas/defeitos.

O comportamento mecânico das fibras de sisal foi avaliado por Silva (2009). Foram utilizados diferentes comprimentos (10, 20, 30 e $40 \mathrm{~mm}$ ), a fim de se avaliar a variabilidade na resistência da fibra, através da distribuição de Weibull. O módulo de Weibull diminuiu (4.6 para 3) à medida em que o comprimento aumentou e, portanto, a variabilidade nos valores de resistência foi maior com o aumento do comprimento. A capacidade de deformação diminuiu (5.2\% para $2.6 \%$ ) com o aumento do comprimento. Esse comportamento se deve ao tamanho médio e a distribuição de falhas da fibra. O tamanho médio das falhas independe do comprimento, porém o número de falhas aumenta com o aumento do volume.

\subsubsection{3}

\section{Ângulo microfibrilar}

Segundo Tomczak (2011) o ângulo microfibrilar influencia no comportamento mecânico da fibra, sendo proporcional à capacidade de deformação. Através da comparação entre os valores de ângulo encontrados na literatura e os valores de deformação obtidos através dos ensaios de tração, tal comportamento foi observado: a fibra de sisal possui maior ângulo microfibrilar e maior capacidade de deformação.

Fibras com pequenos ângulos geralmente apresentam maior resistência e rigidez, enquanto fibras com maiores ângulos proporcionam comportamento 
dúctil (Defoirdt et al., 2010).

O módulo de elasticidade é proporcional ao teor de celulose e inversamente proporcional ao ângulo microfibilar. A fibra de juta, por exemplo, tem alto teor de celulose $(72 \%)$ e ângulo microfibrilar de $8^{\circ}$, no entanto, é uma fibra resistente, com alto módulo de elasticidade (43.9 GPa) e baixa capacidade de deformação (0.6\%). Já a fibra de coco possui baixo teor de celulose (26\%) e grande ângulo microfibrilar, variando entre 30 - 49 , o que explica o fato dessa fibra ter baixa resistência mecânica (90 MPa), baixo módulo (3.8 GPa) e grande capacidade de deformação (18.8\%) (Defoirdt et al., 2010).

\subsubsection{4}

\section{Estrutura da fibra}

Fidelis et al. (2013) observaram que à medida que a área interna dos lúmens diminui e a espessura da parede celular secundária aumenta, a resistência à tração e o módulo de Young da fibra aumentam.

\subsubsection{5}

\section{Índice de cristalinidade}

Fidelis (2014) realizou ensaios de tração nas fibras de juta, sisal, curauá, coco e piaçava, com o objetivo de comparar o comportamento mecânico dessas fibras com a morfologia e composição química. A fibra de curauá apresentou maior índice de cristalinidade, maior resistência mecânica e maior módulo de elasticidade.

\section{4}

\section{Reforço de solos com fibras vegetais}

A maioria dos geotêxteis e produtos relacionados que são utilizados em aplicações de engenharia geotécnica são feitos a partir de materiais sintéticos. Estes produtos geralmente têm um longo tempo de serviço e não sofrem significativa biodegradação, mas eles podem criar problemas ambientais em longo prazo (Venkatappa Rao, 2002).

Desde a criação pelo homem do material polimérico, a percepção de que as fibras naturais têm baixa resistência à tração e um tempo de serviço muito curto (particularmente quando em contato com o solo e água) levaram a recusa de sua utilização na construção. No entanto, geotêxteis de fibra natural têm o potencial para ser apropriado para muitas aplicações geotécnicas, mas este potencial ainda não é apreciado por muitos engenheiros (Costa, 2013).

As fibras naturais podem ter uso na engenharia se o conceito de designe por função for aplicado, ou seja, identificar a variação temporal das funções 
e características necessárias para superar um determinado problema e em seguida fabricar o produto em conformidade (Sarsby, 2006).

Segundo Sarsby (1997) há um significativo número de situações em engenharia geotécnica onde o caso crítico para a estabilização ou funcionalidade é imediatamente após a construção, como uma estrada de acesso construído sobre argila mole saturada, onde a função primária de qualquer reforço é permitir que a estrada seja construída. Além disso, há inúmeras situações em que a estabilidade de um sistema é constante ou aumenta com o tempo após a construção ou a necessidade por completa funcionalidade declina com o tempo.

As fibras vegetais, comparadas às fibras sintéticas, apresentam uma série de vantagens. Elas são de baixo custo, mais fáceis de manusear, têm boas propriedades mecânicas e requerem menos energia no processo de produção, além de serem de fontes renováveis (Dittenber \& GangaRao, 2012). Martins (2014) ressalta que o processo de produção dos compósitos não dispende consumo excessivo de energia, não emite poluentes na atmosfera, não gera quantidades excessivas de resíduos e emprega tecnologias relativamente simples.

Pesquisas avaliando o comportamento mecânico dos solos reforçados com fibras vegetais vêm sendo realizadas (e.g. Ghavami et al., 1999; Prabakar \& Sridhar, 2002; Leocádio, 2005; Pinto, 2007; Sivakumar Babu \& Vasudevan, 2007; Ramesh et al., 2010; Santiago, 2011; Sarbaz et al., 2013; Bolaños, 2013; Carvalho et al., 2014; Sotomayor, 2014; Lekha et al., 2015; Aguilar, 2015; Diab et al., 2018). Nelas é consenso que a adição destas fibras aumenta a resistência de pico, a tenacidade e a ductilidade.

No entanto, as fibras apresentam grande variabilidade das propriedades físicas e mecânicas (cerca de 40\%), fato que afeta a reprodutibilidade dos compósitos, susceptibilidade de degradação em ambientes alcalinos e em ambientes naturais, variações dimensionais por mudanças de teor de umidade e/ou temperatura e interface fibra-matriz com baixa aderência quando o solo é não cimentado (Ghavami et al., 1999).

Como a degradação das fibras poderá afetar os parâmetros de resistência do compósito, a avaliação da durabilidade do compósito deve ser avaliada. Kugan \& Sarsby (2011) reforçam que, a taxa com a qual as propriedades físicas dos geotêxteis de fibra vegetal declinam depois de terem sido incorporados no solo é a questão fundamental.

\section{5}

\section{Durabilidade das fibras vegetais - estudos experimentais}

Segundo Martins (2014), a elevada capacidade de absorção de água das fibras vegetais (entre 100 e 200\%, aproximadamente) é resultante de sua 
estrutura porosa. Para Tolêdo Filho (1997) a umidade entra pela região amorfa das fibras, afastando as moléculas individuais de celulose uma das outras, inchando as fibras.

Tolêdo Filho (1997) realizou ensaio de imersão das fibras de sisal e coco em água de torneira medindo-se as massas a cada $24 \mathrm{~h}$. A completa saturação ocorreu após 10 dias de imersão, com absorção de $230 \%$ pelo sisal e $100 \%$ pelo coco, com a maior parte da absorção nas primeiras $24 \mathrm{~h}$. A variação dimensional avaliada por um micrômetro foi de um aumento de diâmetro de 15\% no sisal e 9\% no coco. A durabilidade das fibras foi avaliada pelo ensaio de tração até 420 dias após serem imersas em água de torneira. Os resultados mostram que, ao final do tempo de imersão, as fibras de sisal e coco retiveram, respectivamente $83.3 \%$ e $77.2 \%$. Concluiu que a perda de resistência tem como causa provável a ação microbiana.

Ghavami et al. (1999) afirma que as variações dimensionais da fibra natural devido a variação da umidade e da temperatura afetam a adesão entre o solo e as fibras. Segundo estes autores, a absorção de água pela fibra gera sua expansão/ inchamento, afastando o solo ao seu redor, pelo menos a nível micro. Quando o compósito perde umidade, a fibra retoma seu tamanho, diminuindo suas dimensões, deixando pequenos vazios a sua volta.

Ghavami et al. (1999) também realizou ensaios de absorção de água com fibras de coco e sisal. Concluiu que ocorre rápida absorção nas primeiras 15 horas, estabiliza após 150 horas nos valores de sisal 225\% (muito mais alta) e coco $90 \%$. Segundo os autores, ocorreu aumento nas dimensões longitudinais e transversais com após absorção por 96 horas: sisal longitudinal 0,84\%, transversal $12.9 \%$ e coco longitudinal $0.12 \%$ e transversal $9.8 \%$.

A biodegradação de fibras naturais é influenciada por vários fatores tais como temperatura, umidade, tipo de fibra, o pH, teor de matéria orgânica e de umidade do solo e assim por diante. Costa (2013) afirma que é importante a determinação do valor de $\mathrm{pH}$ do solo utilizado dada a suscetibilidade química das fibras naturais de origem vegetal em função da acidez ou alcalinidade própria do meio a que são sujeitas.

Toledo Filho (1997) imergiu fibras de coco e sisal em soluções de hidróxido de cálcio $(\mathrm{pH}=12)$ e de hidróxido de sódio $(\mathrm{pH}=11)$ e a perda da resistência à tração com o tempo foi medida para avaliar a durabilidade das fibras. A partir dos resultados, nota-se que a intensidade do ataque alcalino foi maior na solução de hidróxido de cálcio que na solução de hidróxido de sódio. Os resultados mostram que após 210 dias de imersão em solução de hidróxido de cálcio, as fibras de sisal e coco retiveram, respectivamente, 33.7\% e $58 \%$ das suas resistências originais. Após 300 dias, no entanto, toda a sua 
resitência tinha sido perdida. Quando secas, as fibras de sisal e coco perdiam completamente a sua flexibilidade e podiam ser facilmente separadas pela força imposta pelos dedos.

O principal problema que afeta a utilização de fibras naturais como reforço de solo é a perda de resistência à tração com o tempo. Sua perda de resistência pode ser devido a efeitos físicos, químicos ou biológicos, ou devido a uma combinação de todos os três. Dano físico pode ser classificado como a deterioração da lignina que mantém as fibras individuais em conjunto para formar a cadeia de fibra longa. Dano químico ocorre quando as cadeias moleculares nas fibras começam a quebrar. Danos biológicos ocorrem quando bactérias que vivem nas fibras passam a digeri-las. A primeira variável na determinação das taxas de degradação das fibras é considerada como sendo a lignina, que, por si só, é resistente à degradação, e que também diminui a degradação de outros componentes celulares (Chesson, 1997). Celulose por outro lado, serve como uma fonte imediata de energia para os microrganismos do solo e assim, promove a quebra de fibras. A lignina é conhecida por prejudicar a degradação de celulose através da sua proteção (Isaac \& Nair, 2005).

Como as fibras vegetais são materiais de base celulósica, este componente é sujeito à ataque por parte de fungos e bactérias, que o decompõem e fazem uso dos produtos de degradação como alimento. As condições de elevada umidade no solo provocadas pela precipitação potencializam a proliferação destes microrganismos acelerando o processo de biodegradação das fibras resultando em uma rápida deterioração (Alvarez \& Illman, 2005; Costa, 2013; Alvarez \& Illman; 2015). A degradação dos compósitos pela ação de intempéries provoca perda de resistência e ductilidade (Tolêdo Filho, 1997).

Segundo Alvarez \& Illman (2005), bactérias, actinomicetos e fungos constituem a microflora natural do solo e nele podem agir sinergicamente durante a degradação e se reproduzirem em condições naturais. As bactérias e os fungos são os dois grupos principais de microrganismos que são responsáveis pela decomposição microbiana de materiais têxteis naturais. Em comparação com os fungos, as bactérias necessitam de mais umidade para o crescimento, de modo que elas não provocam deterioração tão frequentemente como os fungos (Joy et al., 2011)

Segundo Moreira (2006), os fungos são mais adaptados a valores de $\mathrm{pH}$ menores que 5.0 e bactérias, incluindo actinomicetos (streptomicetos, actinobacterias) e cianobactérias a valores de $\mathrm{pH}$ entre 6 e 8 . A menor incidência de fungos em solos com pH entre 6 e 8 é, provavelmente, devida ao fato de que bactérias e actinomicetos sejam competidores mais eficientes 
prejudicando, assim, o estabelecimento de fungos.

A absorção de umidade pode ser drasticamente reduzida pela modificação química das fibras (Santiago, 2011). O tratamento das fibras busca sanar as questões de instabilidade volumétrica (Fidelis, 2014). Assim, com a finalidade de melhorar a durabilidade dos compósitos, tratamentos vêm sendo realizados nas fibras, a fim de remover impurezas na superfície e melhorar a estabilidade volumétrica da fibra e a transferência de tensões fibra-matriz.

A aplicação de ciclos de molhagem e secagem nas fibras é um tipo de tratamento, cujo processo é conhecido como hornificação (Fidelis, 2014). A hornificação causa às fibras redução na capacidade de retenção de água, além de modificações no comportamento mecânico (Brancato, 2008). Após os ciclos de molhagem e secagem, as paredes celulares da fibra entram em colapso, resultando em modificações de sua estrutura, como redução do diâmetro do lúmen e deformações nas paredes fibrocelulares (Ferreira, 2012).

Claramunt et al. (2011) realizaram um estudo sobre hornificação de fibras vegetais para melhorar durabilidade de compósitos cimentícios. Os autores submeteram fibras de polpa de celulose e algodão a quatro ciclos de molhagem e secagem e avaliaram o comportamento mecânico de compósitos produzidos com essas fibras, através de ensaios de compressão e flexão. Os resultados indicaram que o tratamento das fibras foi benéfico no comportamento mecânico e na durabilidade dos compósitos. Os compósitos reforçados com fibras tratadas apresentaram maior resistência à flexão entre $8 \%$ (compósitos com polpa de celulose) e $16 \%$ (com fibra de algodão), do que compósitos com fibras não-tratadas. Houve uma diminuição da resistência após o envelhecimento. No entanto, os compósitos com fibras tratadas mantiveram resistência na pós-fissuração e os compósitos com fibras não tratadas apresentaram comportamento semelhante à matriz sem reforço.

A remoção de impurezas e de materiais não celulósicos da fibra, feita através de tratamento alcalino $(\mathrm{NaOH})$, proporciona melhoria na resistência à tração da fibra, além de promover melhor molhabilidade e melhor adesão fibramatriz. O tratamento alcalino provoca a separação das fibras, aumentando a área superficial efetiva, propiciando aumento nas propriedades mecânicas do compósito (Saha et al., 2012).

Outro tipo de tratamento das fibras envolve a impregnação com agentes bloqueadores e agentes repelentes à água. Canovas et al. (1990) utilizaram compostos orgânicos derivados da madeira, como taninos, colofônias e óleos vegetais no tratamento de fibras de sisal. Os compósitos com fibras tratadas apresentaram redução na mineralização das fibras, o que foi constatado através dos resultados dos ensaios de permeabilidade e flexão. 
Tolêdo Filho (1997) avaliou a durabilidade dos compósitos com fibras vegetais com e sem tratamento com imersão em microsílica líquida (fibras longas de sisal imersas por 10 minutos e secas ao ar por 15 minutos). Ensaios de durabilidade empregando ciclos de molhagem e secagem e condições atmosféricas naturais foram realizados. Compósitos com fibras naturais sofreram redução significativa da tenacidade após 6 meses, e observa que as fibras curtas se mineralizaram (mais atacadas e fragilizadas) antes das fibras longas. O tratamento das fibras com microsílica criou uma zona de baixo pH ao redor das fibras com objetivo de evitar ou reduzir o ataque alcalino e a mineralização. Concluiu que o tratamento superficial foi efetivo, melhorando resistência e tenacidade dos compósitos com o tempo, sendo as fibras consideradas tão fortes e flexíveis quanto as fibras das amostras não envelhecidas, não apresentou sinal de deterioração até 322 dias de envelhecimento, prevenindo a fragilização.

Ghavami et al. (1999) avaliaram o comportamento físico e mecânico de solo reforçado com fibras de sisal e coco de $50 \mathrm{~mm}$ de comprimento para a produção de blocos para substituir adobe e taipa na construção de casas. Realizaram tratamento com materiais betuminosos (piche e cipla) visando repelir a água. O piche foi o método de impermeabilização mais eficiente, tendo o sisal respondido melhor ao tratamento, já que reduziu drasticamente a absorção após 100 horas de $175 \%$ para $80 \%$. Os autores justificaram este resultado pela microestrutura da fibra de sisal que é mais porosa, podendo absorver mais rápido o produto do tratamento. Ensaios de durabilidade das fibras foram realizados por imersão em água por 210 dias. Concluiram que o tempo de imersão não influencia fortemente na resistência última das fibras, mas diminui o valor da deformação última. O comportamento do compósito solo-fibra foi avaliado variando tipo de fibra, adição de $2 \%$ de emulsão betuminosa e período de secagem (7, 28, 60 e 90 dias). Avaliando as curvas tensão-deformação de todas as amostras com o tempo, observa-se que o envelhecimento não resultou em alteração nos valores de resistência. Adição de material betuminoso no compósito não melhorou a ligação do solo com a fibra, mas aumentou sua durabilidade.

Leocádio (2005) avaliou os efeitos do tratamento de impermeabilização superficial das fibras de sisal com poliestireno expandido (EPS) reciclado nas propriedades do compósito solo laterítico-fibra. A avaliação da deposição do filme polimérico sobre a superfície da fibra feita por microscopia eletrônica de varredura e analise da cinética de absorção de água indicaram a eficiência da impermeabilização superficial como elemento inibidor do processo de absorção de água. A influência do tratamento da fibra no compósito foi avaliada pelos ensaios de compactação, de capacidade de carga (CBR) e pelo ensaio de 
cisalhamento direto. Para a mistura de melhor desempenho tratada superficialmente, a densidade se manteve a mesma, mas a umidade ótima diminuiu. O emprego da mistura ótima com fibras tratadas diminuiu a expansão e aumentou ainda mais a capacidade de carga. A mistura ótima com e sem tratamento das fibras, submetidas às tensões normais de 50, 100 e 200kPa, apresentaram o mesmo comportamento.

Ramesh et al. (2010) avaliou os efeitos da adição de fibras de coco distribuídas aleatoriamente em um solo expansivo encontrado na Índia chamado Black Cotton, sob duas configurações. A primeira combinação é formada por solo, cal e fibra e a segunda combinação é formada por solo e fibra impermeabilizada com betume. Adição de fibra ao solo em geral aumentou a umidade ótima e diminuiu a densidade seca. A fibra tratada reduziu umidade ótima indicando que a capacidade de absorção de água da fibra foi reduzida. Analisando as condições após 180 dias de cura, a condição solo com 4\%cal obteve a maior resistência seguida de solo com $4 \%$ cal e $1 \%$ fibra sem tratamento. As condições solo natural e solo com $1 \%$ fibra tratada obtiveram resistências similares, indicando que o betume reduz o atrito diminuindo a eficiência do reforço. Após 180 dias de cura foi observado fungo branco nos corpos de prova de solo com fibra natural, tal fungo não foi observado nos corpos de prova de solo com fibra tratada.

Joy et al. (2011) avaliaram o efeito da biodegradação dependente do tempo e da profundidade do geotêxtil com fibras de coco sob condições climáticas tropicais. Realizaram ensaios de resistência à tração em amostras de geotêxteis de fibra de coco que foram enterradas em solo laterítico em profundidades de 15, 45, 75 e $100 \mathrm{~cm}$ e então recuperados após 30, 60, 75, 105 e 120 dias. Concluiram que, em geral, a porcentagem de redução da resistência à tração chegou a 70-90\% após 120 dias. A biodegradação do geotêxtil foi mais pronunciada à profundidade de $75 \mathrm{~cm}$. Materiais celulósicos degradam severamente pela atividade microbiana em profundidades rasas comparado com profundidades maiores, portanto a redução da resistência pode ter sido devido ao ambiente alcalino, em vez de a umidade no solo.

Kugan \& Sarsby (2011) investigaram as propriedades de resistência à tração do geotêxtil de palmeira de Buriti visando seu uso em solo reforçado. Os geotêxteis foram enterrados em tanques de areia totalmente saturada e parcialmente saturada por um período de até 12 meses. A taxa de perda de resistência foi muito alta para os enterrados em solo parcialmente saturado e significativamente maior do que os enterrados sob condições totalmente saturadas. Após serem enterrados por 9 meses em areia parcialmente saturada, os geotêxteis foram totalmente decompostos. Enquanto que, após 12 meses 
de enterro na areia totalmente saturada eles ainda mantinham cerca de $40 \%$ de sua resistência inicial. Isto foi explicado pelo fato de que, sob a saturação parcial há mais oportunidade para difusão de oxigénio através do solo e esta disponibilidade de oxigênio permite biodegradação por ambos os microrganismos aeróbios e anaeróbios. Ensaio de Demanda Bioquímica de Oxigênio (DBO) foi realizado para determinar os níveis de microrganismos presentes nos geotêxteis após serem enterrados. Nos primeiros períodos de enterro, quanto menor for o grau de saturação (Sr igual a 25\%) maior foi a presença de microrganismos. Após 3 meses de ensaio, os resultados indicam que não houve significativa influência do teor de umidade na presença de organismos.

Santiago (2011) avaliou o comportamento do solo granular reforçado com inclusão aleatória de fibras de curauá tratadas superficialmente com solução de asfalto e de EPS (poliestireno expandido) reciclado, visando diminuir a higroscopicidade e aumentar a durabilidade da fibra. A análise da fibra tratada por Microscópio Eletrônico de Varredura indica a eficiência dos tratamentos no aumento da durabilidade das fibras vegetais, já que as soluções cobriram a superfície da fibra, e que após exposição por três meses a um fungo padrão, a fibras tratadas foram menos atacadas.

Sarbaz et al. (2014) investigaram a durabilidade das fibras de palmeira e tamareira com e sem tratamento com revestimento de betume Foram feitos ensaios de compactação e de Índice de Suporte Califórnia (CBR) conduzidos em condições secas, submersas (48 horas e de 2 a 5 meses) e 12 ciclos de molhagem e secagem. O CBR diminuiu ligeiramente em corpos de prova reforçados com fibras revestidas com betume, com relação a amostras com fibras naturais. A resistência diminuiu com a submersão das amostras por 48 horas. Após submersão de 2 a 5 meses, a redução do CBR é grande nas primeiras 48 horas depois o CBR se manteve estável. O CBR de amostras reforçadas com fibras tratadas é maior do que as sem reforço e menor do que a com fibra natural. Em todas as amostras submetidas aos 12 ciclos, o CBR diminui insignificantemente (os autores sugeriram aumentar o número de ciclos).

Costa (2013) avaliou o comportamento mecânico e a estrutura fibrosa de geotêxteis de fibras naturais de origem vegetal ao longo do tempo. Foram consideradas as fibras de juta e sisal, incorporadas no solo, sendo este posteriormente exposto a condições ambientais e também a condições controladas, sem ação de agentes climáticos. Concluiu que as fibras expostas a condições ambientais apresentam uma degradação muito superior àquela verificada para condições controladas, comprovando-se como chave a ação da umidade, tempe- 
ratura e incidência de radiação solar no processo de biodegradação deste tipo de materiais. Ressalta que ocorreu rápida e acentuada degradação das propriedades mecânicas das fibras durante as primeiras semanas de exposição no solo. A interação de geotêxteis naturais com o solo e agentes climáticos diversos resulta em um acelerado processo de biodegradação deste tipo de materiais, devido à ação química dos solos e também de microrganismos, tal como pode ser comprovado pela perda significativa de propriedades como a resistência à tração, perda de massa das fibras e degradação da superfície da estrutura fibrosa da juta e sisal. A perda significativa nas propriedades mecânicas se relaciona com a natural perda de matéria existente na composição das fibras. A perda de massa das amostras de fibras em função do tempo de exposição está intimamente relacionada com a perda dos vários constituintes da composição química das fibras (hemicelulose, celulose, lignina entre outros) resultado do processo de biodegradação das mesmas.

Martins (2014) avaliou a incorporação de fibras curtas de sisal em compósitos solo-cimento auto adensáveis, na elaboração de um material que possa ser usado na produção de painéis monolíticos para construções térreas. Pozolanas foram empregadas com objetivo de consumir o hidróxido de cálcio (gerado pela hidratação do cimento e que aumenta a alcalinidade da matriz), que é agente degradante das fibras naturais. A avaliação da durabilidade foi realizada por meio de ensaios a flexão em quatro pontos após etapas de envelhecimento natural (4 e 8 meses) e acelerado. Concluiu que os compósitos mantiveram os mesmo valores de tensão de ruptura e os valores muito próximos de deformação na rupturas após 8 meses de envelhecimento natural e ao fim de 25 ciclos de molhagem e secagem, além de manter as propriedades mecânicas pós-fissuração (queda pós pico, tenacidade, modo de fratura). A manutenção das propriedades mecânicas evidencia a não degradação do reforço fibroso para o período de exposição estudado.

Carvalho et al. (2014) estudou a degradação no comportamento mecânico de fibras naturais de origem vegetal usadas em geotêxteis provocada por envelhecimento acelerado (agentes agressivos simulados em laboratório) e em condições reais (as fibras foram enterradas e sujeitas às condições climatéricas de transição primavera verão em um período de três meses). Foram empregados solo residual granítico (solo ácido com pH 5), com classificação unificada SM, e três tipos de fibras: a de sisal que é uma fibra da folha, a de banana que é uma fibra do caule e a de coco que é uma fibra do fruto. As fibras foram agrupadas em intervalos representativos de massas lineares com o objetivo de estudar seu efeito no desempenho. Concluiu que as amostras de sisal e banana submetidas ao ensaio de envelhecimento em solo (condições de 
calor e umidade, a pressão e abrasão exercidas pelo solo sobre as fibras) apresentam maior perda de resistência ao longo do tempo, que as amostras submetidas ao ensaio de envelhecimento acelerado em QUV, já as fibras de coco apresentam-se com resultado inverso. Em geral, a maior perda de resistência ocorre nos primeiros 15 dias de exposição (360 horas), provocando uma redução da resistência à tração superior a 50\% da sua resistência inicial, e ao final do primeiro mês de exposição verificou-se uma estabilização da perda de resistência, mantendo-se quase inalterável. A análise das fibras estudadas por microscópio eletrônico de varredura mostrou que, para intervalos de massas lineares semelhantes, as fibras de coco são as que apresentam menor degradação, enquanto as fibras de sisal e banana apresentam logo nas primeiras 360 horas de exposição, a presença de orifícios e fissuras. A lenta degradação das fibras de coco é justificada pela sua elevada concentração de lignina em comparação com sisal e banana, já que a lignina é responsável pela resistência das fibras naturais à radiação ultra-violeta o que possivelmente justifica a maior resistência à tração das fibras de coco nos ensaios de envelhecimento em solo, podendo então desempenhar varias funções como separação e reforço de solos. As fibras de sisal poderão ser utilizadas em geotêxteis com função de proteção, pois as fibras podem iniciar a sua degradação quando a vegetação inicia o seu crescimento, tornando-se então biomassa para que a vegetação possa desenvolver-se mais rapidamente. As fibras de banana apresentam uma degradação muito acentuada tornando-as de difícil aplicação em geotecnia.

Fidelis (2014) avaliou o comportamento mecânico de compósitos cimentícios reforçados com fibra de juta. Para aumentar a durabilidade dos compósitos foi utilizada uma matriz com baixo teor de hidróxido de cálcio, além de um tratamento superficial do tecido de juta com o polímero estireno butadieno. O polímero forma um filme que protege a fibra, impedindo o contato da fibra com os produtos de hidratação, permitindo melhorar a estabilidade volumétrica da fibra (devido ao seu comportamento hidrofóbico) e a transferência de tensões fibra-matriz. A durabilidade dos compósitos foi investigada através de processos de envelhecimento acelerado $(5,10,15,20$ e 25 ciclos de molhagem e secagem) e natural (4, 8 e 12 meses de exposição ao intemperismo). Ensaios de tração direta, análises termogravimétrica e microestrutural foram realizados após envelhecimento. O tratamento com polímero contribuiu no aumento da aderência, resistência e durabilidade dos compósitos os quais apresentaram bom comportamento mecânico até 20 ciclos de molhagem e secagem e 8 meses de exposição ao envelhecimento natural. 


\section{3}

\section{Caracterização do solo (matriz do compósito)}

No presente capítulo são apresentadas informações básicas a respeito do solo utilizado como matriz do compósito no presente trabalho, com ênfase para aqueles aspectos de interesse direto no seu desenvolvimento ou que possam fornecer elementos adicionais para o seu melhor entendimento

\section{1}

\section{Materiais e métodos}

\subsection{1}

\section{Solo arenoso}

Um material com comportamento mecânico bem definido e estável foi escolhido de modo a facilitar a interpretação do efeito causado pela adição de fibras. Foi empregada como matriz uma areia (Figura 3.1) proveniente de uma jazida localizada em Porto das Caixas, no município de Itaboraí, no estado do Rio de Janeiro.

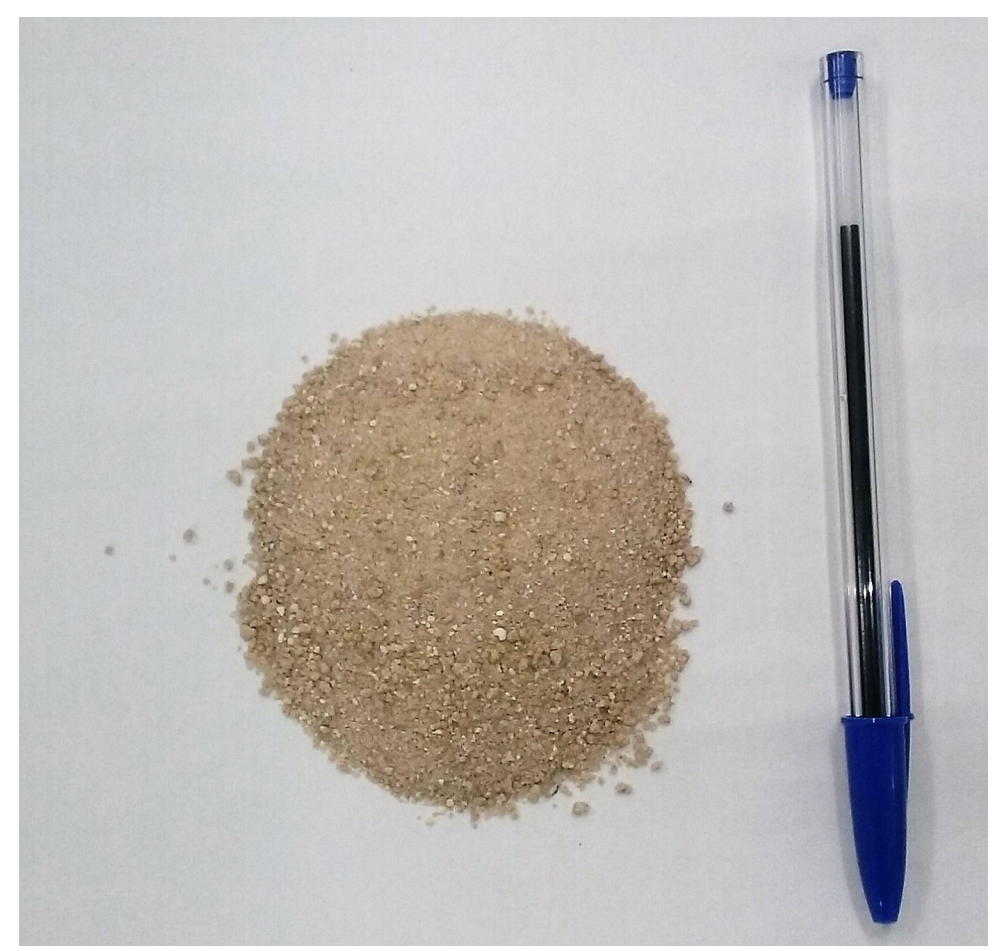

Figura 3.1: Solo arenoso utilizado como matriz do compósito 


\subsection{2}

\section{Caracterização física}

Os ensaios de caracterização física do solo foram realizados no Laboratório de Geotecnia e Meio Ambiente da PUC - Rio, e foram determinados conforme os seguintes métodos e procedimentos:

- Ensaios de granulometria (NBR 7181 - ABNT, 1984a);

- Massa específica real dos grãos (NBR 6508 - ABNT, 1984b);

- Índices de vazios mínimo e máximo (NBR 12051 - ABNT, 1991; NBR 12004 - ABNT, 1990).

\subsection{3}

\section{Caracterização química}

Para a caracterização da composição química da matriz arenosa empregou-se o método de determinação por Fluorescência de Raios-X (FRX) utilizando o equipamento de modelo Rainy EDX 720, da marca Shimadzu. As análises foram realizadas no Laboratório de Caracterização de Combustíveis (LACCOM) da PUC-Rio.

A determinação do pH (potencial hidrogeniônico) fornece a acidez ou alcalinidade do solo. O pH foi determinado na suspensão dos solos em água destilada (proporção 1:2.5) mediante o uso do pHmetro. O ensaio para a determinação do pH foi realizado no Laboratório de Geotecnia e Meio Ambiente da PUCRio conforme o Manual de Métodos de Análises de Solos (CNPS/EMBRAPA, 1997).

\subsection{4}

\section{Caracterização mineralógica}

O estudo da mineralogia tem por objetivo principal identificar os componentes minerais de cada fração do solo, além de permitir descrever as formas dos grãos. A análise foi feita no Laboratório de Estruturas e Materiais da PUC-Rio utilizando-se a lupa binocular da marca Leica e a captura das imagens foi efetuada através do programa da lupa. Antes de serem analisadas, a amostra foi homogeneizada e passada nas peneiras de \#40 (0.42mm) e \#200 $(0.074 \mathrm{~mm})$ a fim de se analisar o comportamento das fases mineralógicas em razão da faixa granulométrica. 


\subsection{5}

\section{Caracterização mecânica}

O estudo do comportamento mecânico do solo arenoso e do compósito areia/fibras vegetais foi realizado através de ensaio triaxial convencional no Laboratório de Geotecnia e Meio Ambiente da PUC-Rio. A seguir são apresentados o método utilizado na preparação das amostras, os detalhes de execução dos ensaios e o equipamento utilizado para o ensaio triaxial.

\subsubsection{1}

\section{A prensa triaxial}

Todos os ensaios triaxiais realizados na matriz arenosa reforçada e não reforçada com fibras vegetais nesta pesquisa foram do tipo consolidado isotropicamente drenado (CID), visando determinar os parâmetros de resistência dos materiais estudados.

Os testes foram realizados utilizando uma prensa da marca WykehamFarrance Eng Ltd (modelo WF10071), com velocidade de deslocamento controlada disponível no Laboratório de Geotecnia e Meio Ambiente da PUC-Rio

Esta prensa possui 10 toneladas-força de capacidade máxima, é dotada de motor elétrico associado a um sistema de engrenagens que permite a adoção de diferentes velocidades de cisalhamento. A câmara triaxial empregada é própria para corpos de prova com diâmetro de 1.5 polegadas. Essa câmara é feita de um material acrílico que suporta uma pressão confinante máxima de $1000 \mathrm{kPa}$

A prensa é equipada com uma célula de carga de $50 \mathrm{kN}$, da marca ELE International Ltd, com resolução de $0.1 \mathrm{kN}$, para medir os acréscimos de força axial, um transdutor de pressão da marca Schaevitz, com capacidade máxima igual a 150 psi (aproximadamente $1034 \mathrm{kPa}$ ), que mede a tensão confinante na câmara e a contrapressão aplicada na amostra, um LSCDT de $25.4 \mathrm{~mm}$ da Wykeham-Farrance, que monitora o deslocamento axial do corpo de prova, e um medidor de variação de volume do tipo Imperial College, projetado e construído na PUC-Rio (de Campos, 1985), que mede a variação volumétrica sofrida pelo corpo de prova.

O sistema de aquisição de dados utilizado no laboratório é o QuantumX da marca HBM, com amplificador universal MX840A e o programa para a aquisição dos sinais é o CatmanEasy da HBM. A Figura 3.2 mostra a visão geral do equipamento triaxial. 

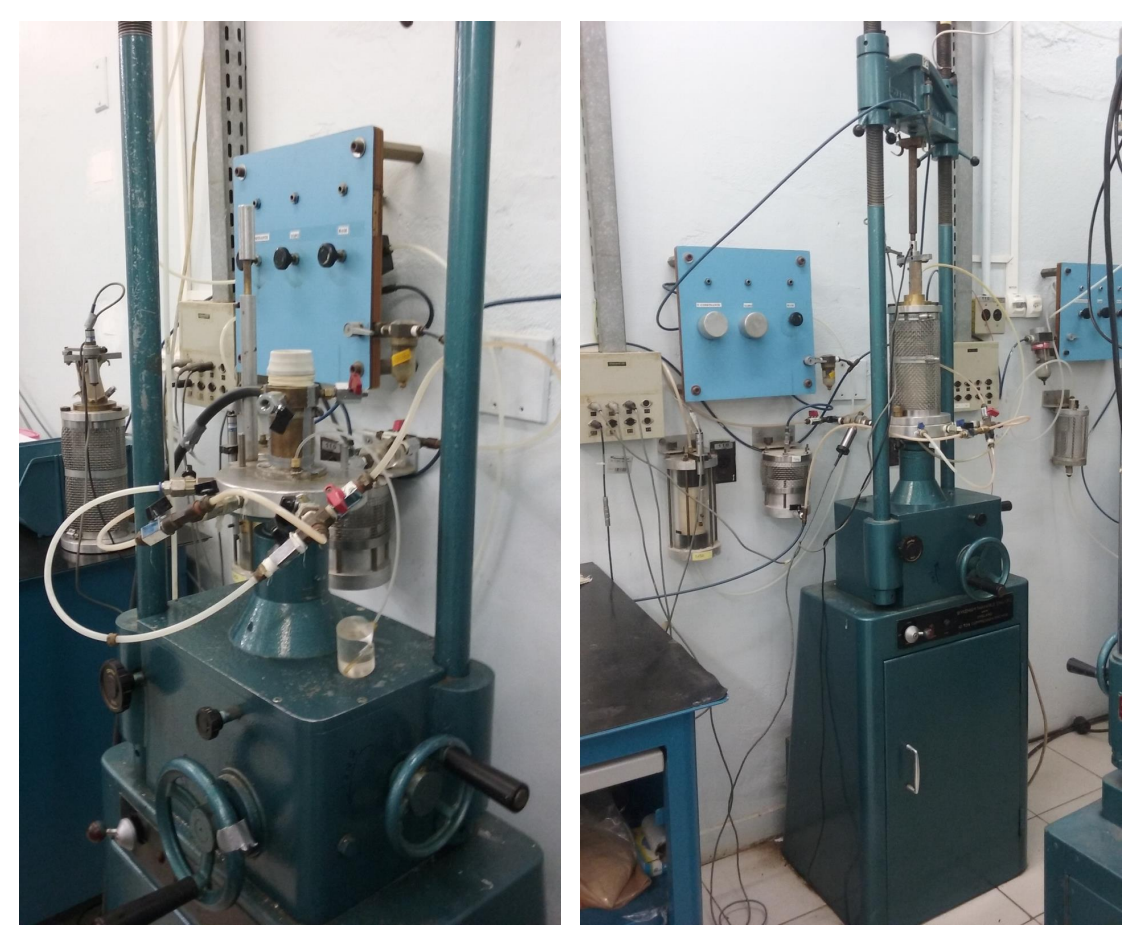

Figura 3.2: Equipamento triaxial

\subsubsection{2}

\section{Parâmetros de moldagem dos corpos de prova}

O valor empregado para densidade relativa foi de $50 \%$. Este valor de densidade relativa corresponde a um índice de vazios de 0.84 e uma massa específica seca de $1.42 \mathrm{~g} / \mathrm{cm}^{3}$. O valor de densidade relativa adotado para o solo arenoso sem reforço foi o mesmo para o compósito solo-fibra.

É costumeiro na pesquisa de solo reforçado com fibras empregar baixas densidades relativas, não na intenção de que a areia reforçada com fibras venha a ser usada na prática com baixa densidade relativa, pois isso seria um uso muito ineficiente do reforço de fibra, mas na intenção de ajudar na compreensão do mecanismo de como as fibras interagem para produzir a resistência extra.

Durante o processo de mistura para confecção dos compósitos de solo reforçado com fibras vegetais aleatoriamente distribuídas foi importante adicionar água para evitar a segregação da areia da fibra. O teor inicial de água adotado foi de $10 \%$ em relação ao peso seco do solo. Este valor de umidade foi adotado tanto para o compósito solo-fibra como para o solo arenoso sem reforço. A mistura foi feita manualmente até ser obtida a homogeneização dos componentes, verificada visualmente.

Os parâmetros de moldagem das amostras de solo e solo-fibra foram os mesmos usados por Casagrande (2005), Girardello (2010), Santiago (2011), Santos (2012), Sotomayor (2014), Louzada (2015), Aguilar (2015) e Senez 
(2016).

\subsubsection{3}

\section{Preparo das amostras para o ensaio triaxial}

A moldagem dos corpos de prova para os ensaios triaxiais convencionais foi realizada em moldes de $40 \mathrm{~mm}$ de diâmetro por $86 \mathrm{~mm}$ de altura (Figura 3.3). Os corpos de prova foram compactados diretamente sobre o pedestal da prensa triaxial, dentro de membranas flexíveis e impermeáveis, utilizando-se um molde tri-partido apropriado para este tipo de moldagem. As amostras foram compactadas manualmente em três camadas, controlando o peso da mistura adicionada e a altura das camadas de forma a obter a densidade desejada.
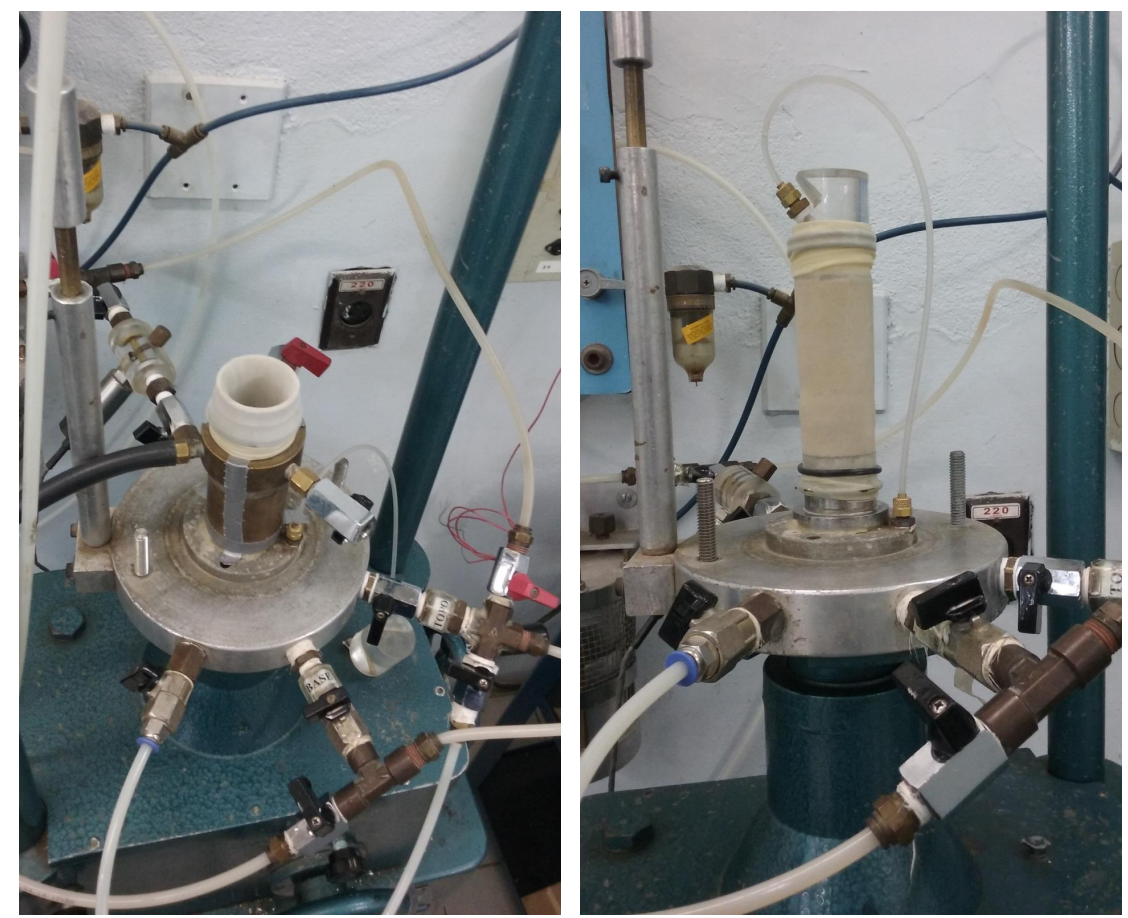

Figura 3.3: Moldagem do corpo de prova no equipamento triaxial

\subsubsection{4}

\section{Ensaio triaxial convencional}

Os procedimentos gerais adotados na execução dos ensaios triaxiais seguiram os princípios descritos por Head (1998) e pelos procedimentos de ensaios já consolidados pelo Laboratório de Geotecnia e Meio Ambiente da PUC-Rio.

Após a montagem do corpo de prova na câmara triaxial iniciava-se a fase de saturação da amostra. O processo de saturação foi feito preferencialmente 
por percolação de água através das amostras. Nesta etapa, a diferença de pressão entre base e topo do corpo de prova foi de $5 \mathrm{kPa}$, sendo o sentido de percolação da base para o topo, e a amostra era submetida a uma tensão confinante efetiva de $10 \mathrm{kPa}$ para impedir o fluxo preferencial entre o corpo de prova e a membrana.

A saturação da amostra foi monitorada através da medição do parâmetro $\mathrm{B}$ de Skempton até que atingisse um valor de 0.95 medido antes da fase de adensamento. A partir daí, aplicava-se a tensão confinante e procedia-se à fase de adensamento isotrópico da amostra.

Todos os ensaios foram realizados sob tensão confinante efetiva de 50, 100 e $150 \mathrm{kPa}$. Esses valores são coerentes com as premissas realistas feitas em algumas aplicações de engenharia, como fundações rasas assentadas nas camadas melhoradas do solo.

O critério apresentado em Head (1998) foi empregado para definir a velocidade de cisalhamento. A velocidade de $0.030 \mathrm{~mm} / \mathrm{min}$ foi usada em todos os testes. Esta etapa foi realizada com as válvulas de drenagem abertas (ensaio do tipo drenado). A compressão axial normalmente permanecia até atingir $20 \%$ da deformação axial.

Foi observado, para a maioria dos casos, forma de ruptura do tipo plástica com "embarrigamento" dos corpos de prova. Sendo assim, foi aplicada a fórmula de correção de área proposta por Bishop \& Henkel (1962), para este tipo de ruptura.

Os resultados dos ensaios triaxias são apresentados em conjunto de quatro gráficos: q vs $\varepsilon_{a}$, p' vs q, $\varepsilon_{v}$ vs $\varepsilon_{a}$, e vs p', onde p' $=$ tensão efetiva média, q $=$ tensão desviadora, $\varepsilon_{a}=$ deformação axial, $\varepsilon_{v}=$ deformação volumétrica, e= índice de vazios. A tensão efetiva média e a tensão desviadora são obtidas pelas seguintes equações:

$$
\begin{gathered}
p^{\prime}=\frac{\sigma_{1}^{\prime}+2 . \sigma_{3}^{\prime}}{3} \\
q=\sigma_{1}^{\prime}-\sigma_{3}^{\prime}
\end{gathered}
$$

Onde: $\sigma_{1}$ e $\sigma_{3}$ são as tensões principais maior e menor, respectivamente.

As envoltórias de resistência bem como os valores do intercepto coesivo e do ângulo de atrito interno obtidos a partir de ensaios triaxiais em amostras de areia reforçada e não reforçada com fibras vegetais foram obtidos para os valores de máxima tensão desviadora. 
Os parâmetros de resistência ao cisalhamento de Mohr-Coulomb ( $\phi^{\prime}$ e c') foram calculados a partir da relação entre $\eta$ que é a inclinação e $Q_{0}$ que é o intercepto da linha de ruptura no espaço p-q. O ângulo de atrito interno $\phi^{\prime}$ e coesão c' em termos efetivos foram calculados usando as seguintes equações de conversão:

$$
\begin{aligned}
& \sin \phi^{\prime}=\frac{3 \cdot \tan \eta}{6+\tan \eta} \\
& c^{\prime}=\frac{3-\sin \phi^{\prime}}{6 \cdot \cos \phi^{\prime}} \cdot Q_{0}
\end{aligned}
$$

Os valores da capacidade de absorção de energia $\left(E_{\text {def }}\right)$ também são apresentados. A capacidade de absorção de energia é a área sob a curva q vs $\varepsilon_{a}$ e avalia a capacidade do material de absorver energia ao se deformar. A capacidade de absorção de energia é definida pelo produto entre a tensão desviadora e a variação da deformação axial correspondente, que neste caso foi avaliada até a deformação axial de $20 \%$.

\section{2}

\section{Apresentação e análise dos resultados de caracterização do solo}

Neste item são apresentados e analisados os resultados dos ensaios de caracterização do solo arenoso utilizado como matriz do compósito solo-fibra vegetal neste trabalho.

\subsection{1}

\section{Caracterização física}

A curva granulométrica e os índices físicos da matriz são apresentados na Figura 3.4 e na Tabela 3.1, respectivamente. Este material caracterizase por ser uma areia média (NBR 6502 - ABNT, 1995). De acordo com o Sistema Unificado de Classificação de Solos (SUCS), esta é uma areia unifome classificada como areia mal graduada (SP). Durante a caracterização do material não foi observada a presença de matéria orgânica. 


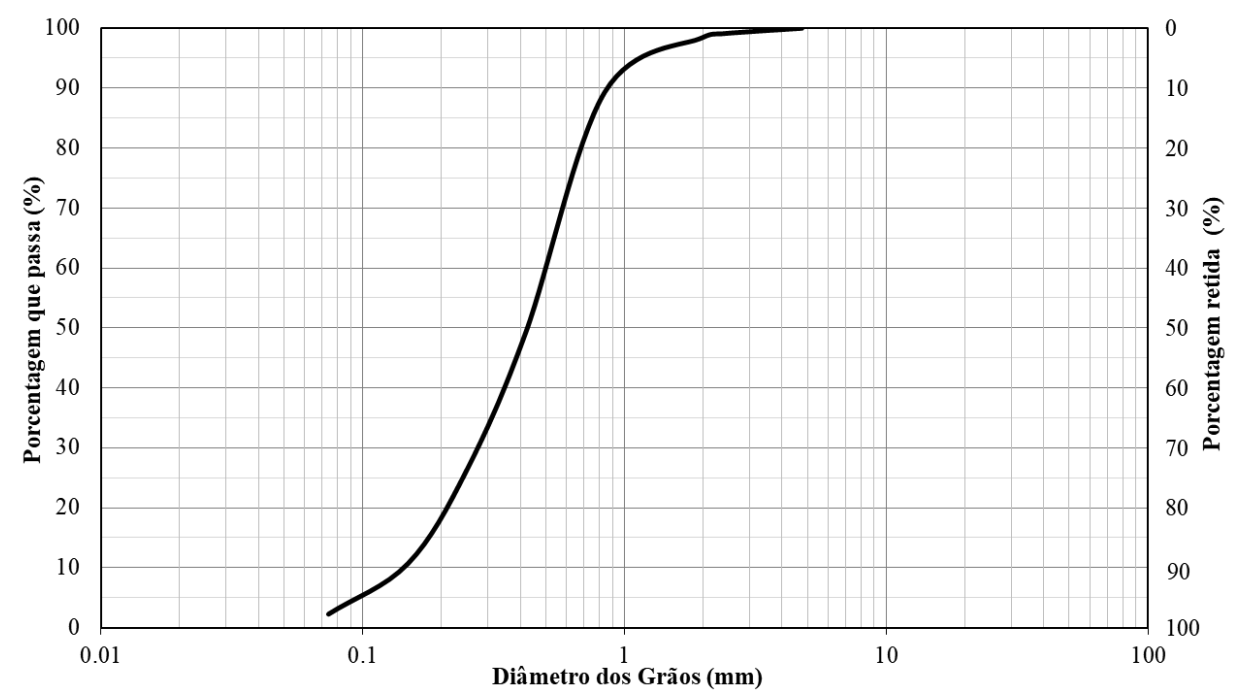

Figura 3.4: Curva granulométrica da areia de Itaboraí

Tabela 3.1: Índices físicos da areia de Itaboraí

\begin{tabular}{cc}
\hline Índices Físicos & Valor \\
\hline Densidade real dos grãos $\left(G_{s}\right)$ & 2.63 \\
Diâmetro efetivo $\left(D_{10}\right)$ & $0.15 \mathrm{~mm}$ \\
Diâmetro médio $\left(D_{50}\right)$ & $0.43 \mathrm{~mm}$ \\
Coeficiente de uniformidade $\left(C_{u}\right)$ & 3.33 \\
Coeficiente de curvatura $\left(C_{c}\right)$ & 0.97 \\
Índice de vazios máximo $\left(e_{\max }\right)$ & 0.98 \\
Índice de vazios mínimo $\left(e_{\min }\right)$ & 0.71 \\
\hline
\end{tabular}

\subsection{2}

\section{Caracterização química}

A composição química do solo arenoso é apresentada na Tabela 3.2. Através desta análise foram obtidos os teores de sílica $\left(\mathrm{SiO}_{2}\right)$, alumina $\left(\mathrm{Al}_{2} \mathrm{O}_{3}\right)$, potássio $\left(\mathrm{K}_{2} \mathrm{O}\right)$, óxido de titânio $\left(\mathrm{TiO}_{2}\right)$ e ferro $\left(\mathrm{Fe}_{2} \mathrm{O}_{3}\right)$, dentre outros elementos presentes nos solos. Este resultado confirma a presença marcante de sílica, já esperada, e aponta a presença de alumina como o segundo elemento mais representativo.

$\mathrm{O}$ valor de $\mathrm{pH}$ em água obtido para a areia foi de 4.4, o que mostra que a matriz do compósito é ácida $(\mathrm{pH}<7)$. Segundo Moreira (2006), a maioria dos solos tem pH entre 4.0 e 8.5. Os horizontes superficiais de solos em climas mais úmidos são geralmente ácidos devido à lixiviação de bases e decomposição da serrapilheira. A fertilização pesada, a chuva ácida e até a fixação biológica de nitrogênio também podem contribuir para abaixar o pH do solo. Já os solos de regiões mais secas ou semi-áridas são geralmente alcalinos. 
Tabela 3.2: Composição química da areia de Itaboraí

\begin{tabular}{ccccccc}
\hline \multirow{2}{*}{ Amostra } & \multicolumn{6}{c}{ Constituintes em porcentagens } \\
& $\mathrm{SiO}_{2}$ & $\mathrm{Al}_{2} \mathrm{O}_{3}$ & $\mathrm{~K}_{2} \mathrm{O}$ & $\mathrm{TiO}_{2}$ & $\mathrm{Fe}_{2} \mathrm{O}_{3}$ & outros \\
\hline Matriz arenosa & 66.02 & 30.01 & 3.20 & 0.50 & 0.21 & 0.06 \\
\hline
\end{tabular}

\subsection{3}

\section{Caracterização mineralógica}

As fases mineralógicas identificadas são quartzo, muscovita, k-feldspato, óxidos e hidróxidos de ferro (Figura 3.5). A amostra é constituída por quartzo (85\%) com baixo grau de esfericidade e arredondamento e alta angulosidade evidenciando pouco ou nenhum transporte desse material. O k-feldspato, muscovita, óxidos e hidróxidos ocorrem em pequenas proporções e totalmente liberados em ambas as frações granulométricas.

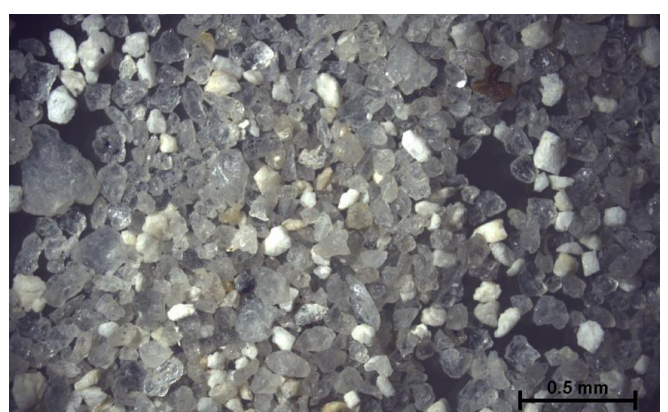

(a)

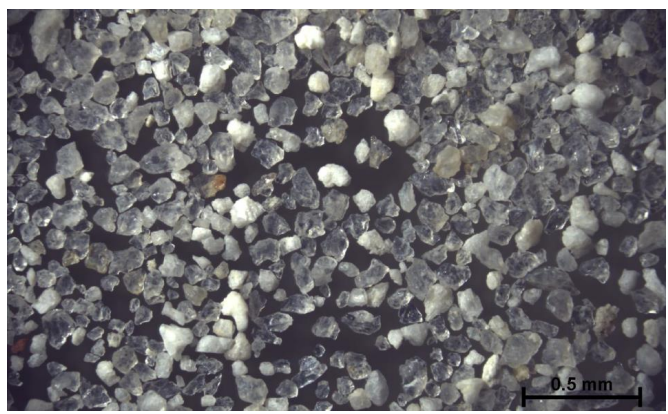

(b)

Figura 3.5: Aspecto macroscópico da amostra de solo: (a) fração retida na peneira $n^{\circ} 40$ e (b) fração de areia passante na peneira de $n^{\circ} 40$ e retida na peneira de $n^{\circ} 200$.

Como apresentado, as análises químicas indicam que as amostras são constituídas essencialmente por $\mathrm{SiO}_{2}, \mathrm{Al}_{2} \mathrm{O}_{3}$ e $\mathrm{K}_{2} \mathrm{O}$. Elevados teores de $\mathrm{SiO}_{2}$ confirmam, junto a descrição por lupa, uma grande quantidade de quartzo presente. Os teores de $\mathrm{Al}_{2} \mathrm{O}_{3}$ indicam uma provável ocorrência de minerais secundários argilosos na amostra, podendo estes serem frutos de transformações secundarias.

\subsection{4}

\section{Caracterização mecânica}

Neste item são apresentados e analisados os resultados de três ensaios triaxiais CID, com tensões confinantes de 50, 100 e $150 \mathrm{kPa}$, realizados no solo arenoso. Na Figura 3.6 apresentam-se em conjunto quatro gráficos obtidos para a série de ensaios drenados: q vs $\varepsilon_{a}$, p' vs q, $\varepsilon_{v}$ vs $\varepsilon_{a}$, e vs p'. Os valores de 
índice de vazios após adensamento e ao final do ensaio além da umidade final, são apresentados na Tabela 3.3.
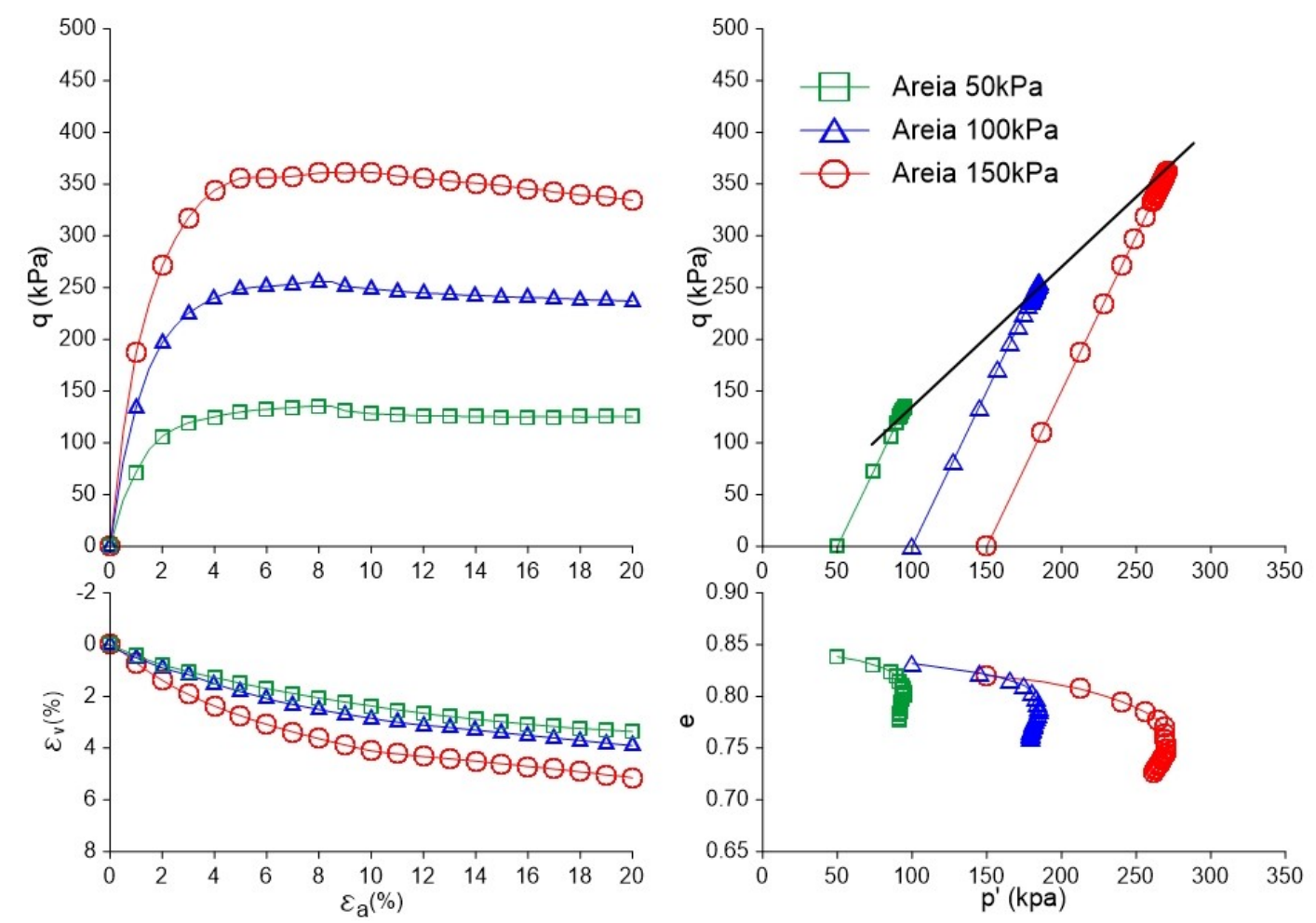

Figura 3.6: Resultado dos ensaios triaxiais do solo arenoso

Tabela 3.3: Índices físicos após o adensamento e no final do ensaio, dos corpos de prova de solo arenoso sem reforço

\begin{tabular}{ccccc}
\hline & & $\begin{array}{c}\text { Após o } \\
\text { adensamento }\end{array}$ & \multicolumn{2}{c}{$\begin{array}{c}\text { Após o } \\
\text { cisalhamento }\end{array}$} \\
\cline { 3 - 6 } Amostra & $\sigma_{3}^{\prime}$ & & & $w_{\text {final }}$ \\
& & $e_{\text {adens }}$ & $e_{\text {final }}$ & $(\%)$ \\
\hline \multirow{4}{*}{ Areia } & 50 & 0.838 & 0.776 & 26.874 \\
& 100 & 0.832 & 0.760 & 26.313 \\
& 150 & 0.820 & 0.726 & 25.139 \\
\hline
\end{tabular}

Analisando as curvas q vs $\varepsilon_{a}$ observa-se, que a resistência aumenta com o aumento da tensão confinante efetiva, e a rigidez inicial do solo também aumenta com o aumento da tensão efetiva de confinamento.

As amostras de solo arenoso não reforçadas com fibras vegetais apresentam comportamento típico de solos arenosos no estado fofo, caracterizado por uma tensão desviadora que cresce lentamente com a deformação até atingir um valor máximo em deformações relativamente altas (8- 9\%) sem a ocorrência de um claro pico de resistência em todas as tensões efetivas utilizadas, ou seja, as 
amostras apresentam um comportamento elastoplástico perfeitamente plástico com ruptura dúctil.

Nas curvas $\varepsilon_{v}$ vs $\varepsilon_{a}$, nota-se uma tendência de redução de volume para todas as tensões confinantes empregadas, sendo esta redução tanto maior quanto maior for o valor da tensão confinante. A redução de volume durante o carregamento axial é um comportamento típico dos solos arenosos no estado fofo.

Nas curvas de e vs p', nota-se que a variação do índice de vazios com p' durante a fase de cisalhamento mostra um comportamento similar para os corpos de prova ensaiados. Os primeiros pontos referem-se aos índices de vazios após a fase de adensamento isotrópico.

A Tabela 3.4 apresenta os valores obtidos para tensão desviadora e deformação axial de ruptura, a capacidade de absorção de energia $\left(E_{\text {def }}\right)$ e os parâmetros de resistência ao cisalhamento (c' e $\phi^{\prime}$ ) obtidos da amostra de solo arenoso sem reforço.

Tabela 3.4: Valores das propriedades mecânicas e dos parâmetros de resistência para a amostra de solo arenoso sem reforço

\begin{tabular}{ccccccc}
\hline Amostra & $\sigma_{3}^{\prime}$ & $\begin{array}{c}\text { Tensão } \\
\text { desviadora } \\
\text { de ruptura } \\
(\mathrm{kPa})\end{array}$ & $\begin{array}{c}\text { Deformação } \\
\text { axial }\end{array}$ & $\begin{array}{c}E_{\text {def }} \\
(\%)\end{array}$ & $\mathrm{c}^{\prime}$ & $\phi^{\prime}$ \\
& $(\mathrm{kPa})$ & $\begin{array}{c}\left.\mathrm{kJ} / m^{3}\right) \\
(\mathrm{kPa})\end{array}$ & $\left(^{\circ}\right)$ \\
\hline \multirow{3}{*}{ Areia } & 50 & 135.66 & 8.00 & 24.17 & & \\
& 100 & 255.92 & 8.00 & 46.12 & 0.0 & 33.59 \\
& 150 & 361.64 & 9.50 & 65.86 & & \\
\hline
\end{tabular}

Os valores do intercepto coesivo e do ângulo de atrito interno obtidos para o solo arenoso estão condizentes com a faixa de valores típicos para este material. Quanto aos valores de capacidade de absorção de energia de deformação, observa-se que estes aumentam com o aumento da tensão confinante. 


\section{4 \\ Caracterização das fibras vegetais (elemento de reforço do compósito)}

No presente capítulo são apresentadas informações básicas a respeito das fibras vegetais utilizadas como elementos de reforço dos compósitos no presente trabalho, com ênfase para aqueles aspectos de interesse direto no seu desenvolvimento ou que possam fornecer elementos adicionais para o seu melhor entendimento. Os tratamentos por impermeabilização superficial das fibras também são apresentados, bem como informações a respeito das fibras tratadas. Todas as análises apresentadas neste item foram realizadas em fibras no tempo zero sem exposição aos agentes climáticos e ao tempo.

\section{1}

Materiais e métodos

\subsection{1}

\section{Fibras de sisal e curauá}

As fibras a serem utilizadas como elementos de reforço de solos são as fibras vegetais de curauá (Ananás erectifolius) e de sisal (Agave sisalana) (Figura 4.1). Algumas informações sobre estas fibras foram apresentadas nas Seções 2.3.1 e 2.3.2. As fibras de curauá são comercializadas pela empresa Pematec Triangel do Brasil, da cidade de Santarém/ Pará e as fibras de sisal são comercializadas pela Associação de Desenvolvimento Sustentável e Solidário da Região Sisaleira (APAEB), do município de Valente/ Bahia. Ambas as fibras são extraídas das folhas das plantas pelo processo mecânico chamado decorticação. Nesse processo, as folhas são esmagadas por um rolo em movimento coberto de facas, onde somente as fibras prevalecem.

Estas fibras vegetais foram escolhidas por apresentarem boas propriedades mecânicas e pela necessidade de novas matérias-primas provenientes de fontes renováveis, que possam substituir com sucesso as fibras sintéticas. A utilização de fibras vegetais, além de garantir a confecção de um produto ecologicamente correto, pode garantir uma nova alternativa de renda para agricultores das regiões produtoras quando produzidas em escala industrial. 


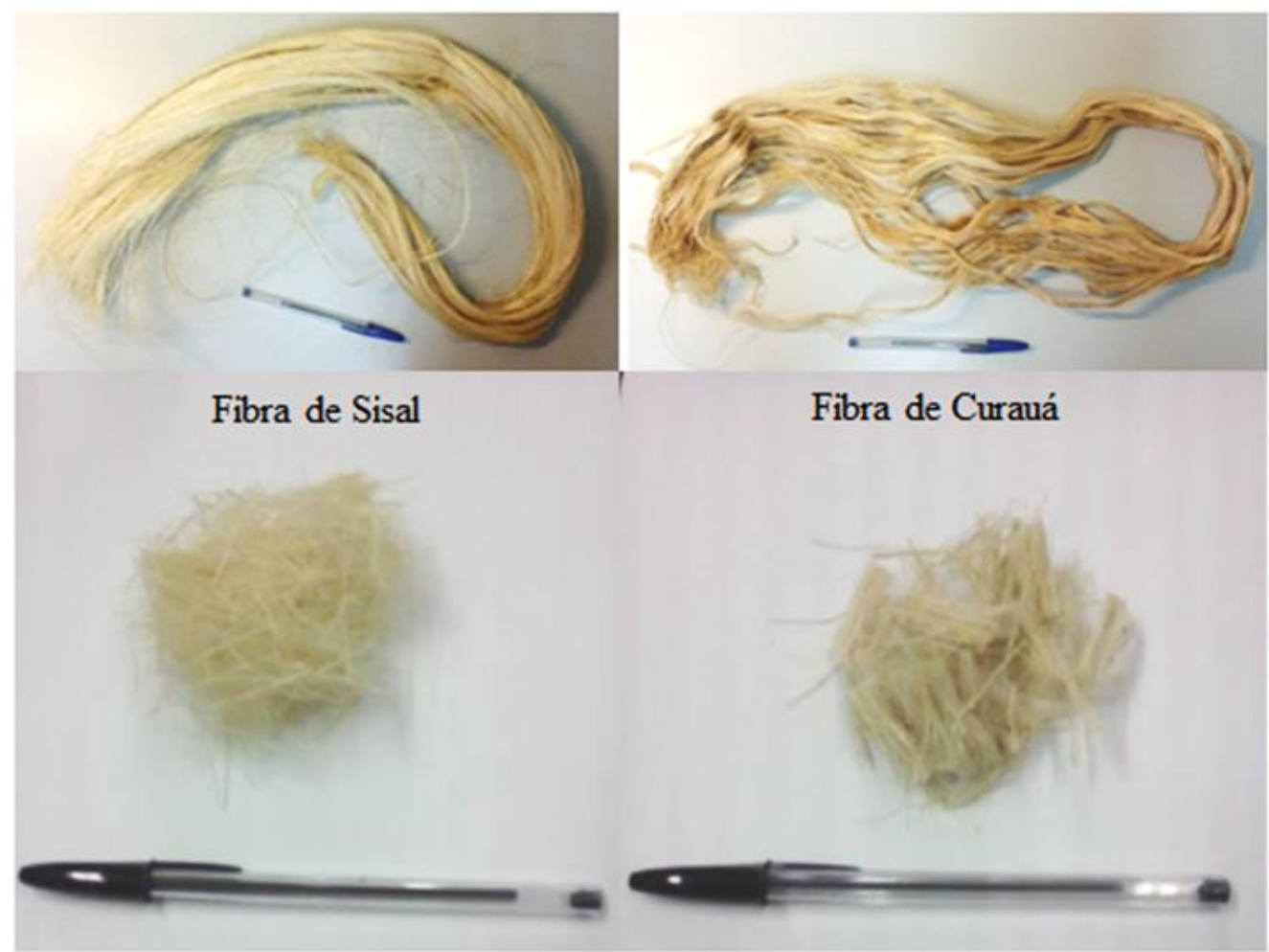

Figura 4.1: Fibras vegetais de Sisal e Curauá

Para a definição dos teores e comprimentos de fibras a serem incorporados no solo, foi adotada os valores empregados na literatura. Em geral, os teores adotados em geotecnia são pequenos chegando até $1 \%$ em função da massa seca do solo. Há relatos de problemas de trabalhabilidade e baixa resistência do material quando se incorpora teor de 1.0\% (Pinto, 2007; Leocádio, 2005; Prabakar \& Sridhar, 2002). Quanto ao comprimento, quando se adota fibras curtas, implica-se que o comprimento será de no máximo $50 \mathrm{~mm}$.

Prabakar \& Sridhar (2002) adotaram 0.25, 0.5, 0.75 e 1\% de fibras (sisal) e comprimentos 10, 15, 20 e $25 \mathrm{~mm}$. Leocádio (2005) adotou teores de $0.25 \%$ a $1.0 \%$ de fibras (sisal) e comprimentos de 10, 15, 20 e $25 \mathrm{~mm}$. Santiago (2011) adotou $0.5 \%$ de fibras (sisal e curauá) e comprimentos de 24, 36 e $50 \mathrm{~mm}$ para reforço de um solo arenoso.

Assim, baseado em estudos anteriores, optou-se por empregar nos compósito estudados neste trabalho comprimento das fibras de $25 \mathrm{~mm}$ e teor de fibras de $0.5 \%$, calculado em relação à massa de solo seco.

Ambas as fibras foram compradas na forma de fardos e em comprimentos de aproximadamente de $1.2 \mathrm{~m}$. Devido à presença de resíduos aderidos na superfície das fibras (graxas e resinas naturais), as fibras foram submetidas a um processo de beneficiamento que consistiu de uma lavagem em água quente 
Capítulo 4. Caracterização das fibras vegetais (elemento de reforço do compósito)

$\left(100^{\circ} \mathrm{C}\right)$ e secagem em estufa $\left(60^{\circ} \mathrm{C}\right)$. As fibras submetidas a este processo de beneficiamento já estavam cortadas no comprimento de trabalho (25mm). Após secagem em estufa e esfriamento ao ar, as fibras foram acondicionadas em sacos plásticos hermeticamente fechados até o momento em que foram utilizadas.

\subsection{2}

\section{Tratamentos por impregnação}

O tratamento de fibras vegetais apresenta-se como alternativa de melhoria da durabilidade do compósito. Na literatura são apresentado varios tipos de tratamentos. Os tratamentos empregados nessa pesquisa foram o tratamento por impregnação com sílica coloidal e com copolímero de estireno-butadieno carboxilado.

A sílica (LUDOX® TM-50 colloidal silica (50 wt.\% suspension in $\mathrm{H}_{2} \mathrm{O}$ )) é comercializada pela empresa Sigma-Aldrich. O polímero (Copolímero de butadieno e estireno modificado com ácido carboxílico (XSBR)- NTL-218) foi cedido pela empresa Nitriflex. A Tabela 4.1 apresenta as propriedades físicas e químicas da sílica e do polímero, fornecidas pelos fabricantes. Alimardani \& Abbassi-sourki (2014) apresentam a estrutura molecular do polímero estireno butadieno carboxilado (Figura 4.2).

Tabela 4.1: Propriedades físicas e químicas dos tratamentos superfíciais estudados

\begin{tabular}{rcc}
\hline \multicolumn{1}{c}{ Propriedades } & Sílica & XSBR \\
\hline Aparência & Líquido viscoso & Líquido branco \\
$\mathrm{pH}$ & $8.5-9.5$ & 9.0 \\
Densidade & $1.388-1.407$ & \\
Fórmula & $\mathrm{O}_{2} S i$ & \\
Peso da fórmula & $60.08 \mathrm{~g} / \mathrm{mol}$ & \\
Viscosidade Brookfield & $55 \mathrm{cP}$ & $150 \mathrm{cP}$ \\
\hline
\end{tabular}

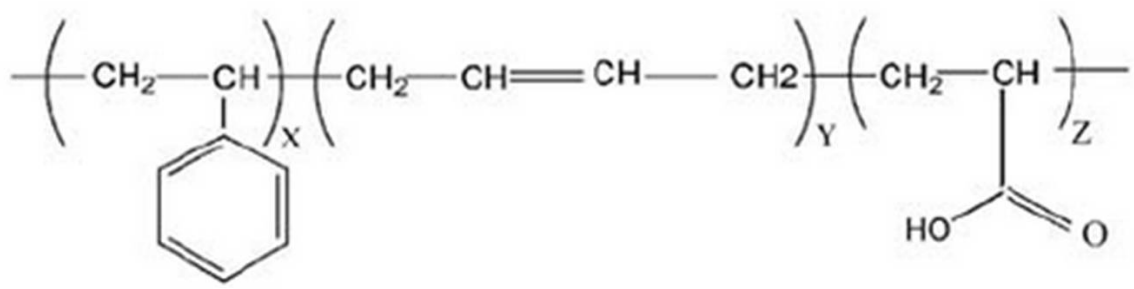

Figura 4.2: Estrutura molecular do estireno butadieno carboxilado (XSBR)

Esses tratamentos tem por finalidade formar uma barreira física para proteger a fibra. A deposição de sílica em plantas para a formação de uma 
Capítulo 4. Caracterização das fibras vegetais (elemento de reforço do compósito)

barreira física à penetração e redução da susceptibilidade à degradação enzimática por patógenos fúngicos tem sido há muito tempo estudada e empregada (Currie \& Perry, 2007). Segundo o fabricante do XSBR, este latex apresenta excelente adesão à maioria das fibras naturais e sintéticas formando um filme à temperatura ambiente e é indicado para utilização em base para tapetes e carpetes.

O tratamento superficial por impregnação das fibras vegetais foi realizado com as fibras já cortadas no comprimento a ser utilizado no compósito (25mm). A escolha do tempo de impregnação das fibras por imersão em sílica e em polímero baseou-se no ensaio de absorção das fibras em água e o tempo de 120 minutos foi escolhido por ser quando as fibras chegam à um limite de ganho de massa.

Passado o tempo de imersão em sílica e em polímero, a mistura solução/fibra era então escorrida em peneira, a solução livre era armazenada e um jato de ar era aplicado nas fibras retidas na peneira para retirar o excesso do tratamento e evitar o agrupamento das fibras. Retirado o excesso de tratamento, as fibras foram secas em estufa $\left(60^{\circ} \mathrm{C}\right)$ até constância de massa.

A proposta inicial era a de realizar o tratamento através da imersão das fibras em soluções $100 \%$ sílica e $100 \%$ polímero. No entanto, após a secagem em estufa, as fibras assim tratadas permaneciam grudadas umas as outras, impedindo sua adição à matriz arenosa de forma aleatoriamente distribuída. Neste sentido, os tratamentos precisaram ser misturados com água destilada até teores que permitissem a trabalhabilidade das fibras tratadas após sua secagem. A trabalhabilidade desejada foi atingida ao se misturar o tratamento em água destilada na proporção de 1:2.

Realizadas as etapas de tratamento foi possível determinar o consumo de solução necessário e o ganho de massa das fibras devido a impregnação com sílica e polímero.

\subsection{3}

\section{Capacidade de absorção em água}

Ensaio de absorção de água foi realizado nas fibras vegetais com e sem tratamento, para efeito comparativo.

O teste foi realizado em quadruplicata, utilizando-se fibras com $25 \mathrm{~mm}$ de comprimento e pesando $1 \mathrm{~g}$. As fibras foram analisadas sem secagem prévia.

As fibras foram imersas em água destilada e após 1, 2, 4, 8, 15, 30, 60, 120, 240 e 480 min as fibras eram retiradas, secas com papel toalha e pesadas, permitindo traçar uma curva ganho de massa vs tempo e com isso determinar a capacidade de absorção de água. 
Capítulo 4. Caracterização das fibras vegetais (elemento de reforço do compósito)

\subsection{4}

\section{Análise microestrutural}

Para a análise microestrutural das fibras vegetais com e sem tratamento foi utilizado o microscópio eletrônico de varredura (MEV) SEM Hitachi TM3000 disponível no Laboratório de Estruturas e Materiais Prof. Lobo Carneiro (LABEST/COPPE/UFRJ). O microscópio foi operado sob uma tensão de aceleração de $15 \mathrm{kV}$. As análises foram realizada em um ambiente de baixo vácuo, e nenhum pré-revestimento foi feito. A área da seção transversal foi medida empregando o software ImageJ, um programa de processamento de imagem baseado em Java.

O preparo das amostras consistiu em imersão das fibras em água destilada por $48 \mathrm{~h}$ e posterior corte da seção transversal com lámina.

\subsection{5}

\section{Espectroscopia no Infravermelho por Transformada de Fourier (FTIR)}

A técnica de FTIR é utilizada para a análise química de grupos funcionais em moléculas orgânicas. Ela permite identificar as mudanças produzidas pelo tratamento superficial nos componentes das fibras vegetais.

Os espectros das amostras de fibras vegetais com e sem tratamento foram obtidos com um espectrômetro de infravermelho de modelo Nicolet IR200 (Thermo Scientific, EUA) disponível no Laboratório de Caracterização de Combustíveis (LACCOM) da PUC-Rio.

Os espectros foram obtidos nas seguintes condições: um "background"com a célula limpa antes de cada espectro, 120 leituras por espectro, resolução de $4 \mathrm{~cm}^{-1}$ e região de aquisição de 4000 a $500 \mathrm{~cm}^{-1}$. Todos os espectros foram obtidos na transmissão.

As amostras foram apicoadas em partículas de tamanho menor que 1 mm, misturadas com pó de Brometo de potássio $(\mathrm{KBr})$ para um melhor contato ótico e compactadas para a formação de uma pastilha. A pastilha confeccionada era então transferida para um porta-amostra e levada para análise.

\subsection{6}

\section{Espectrometria de Fluorescência de Raios-X (FRX)}

A técnica de FRX permite realizar análises de materiais, estabelecendo e identificando de forma quantitativa e qualitativa as composições químicas presentes nas amostras. Análises foram realizadas nas fibras vegetais com e sem tratamento.

O preparo constiste no apicoamento das fibras em partículas de tamanho menor que $1 \mathrm{~mm}$ e seu acondicionamento em um porta-amostras próprio para 
Capítulo 4. Caracterização das fibras vegetais (elemento de reforço do compósito)

o ensaio. As análises foram realizadas em equipamento do modelo Rayny EDX-700, marca Shimadzu, disponível no Laboratório de Caracterização de Combustíveis (LACCOM) da PUC-Rio.

\subsection{7}

\section{Ensaio de Difração de Raios-X (DRX)}

A análise por DRX tem por objetivo determinar o índice de cristalinidade da fibra, diretamente relacionada à celulose. Quanto maior o grau de cristalinidade, melhor o alinhamento das cadeias e, portanto, maior a resistência mecânica das fibras (Canevarolo, 2006).

Análises de DRX foram realizadas nas fibras vegetais sem tratamento e o preparo consistiu no apicoamento das fibras em partículas de tamanho menor que $1 \mathrm{~mm}$ e compactação das mesmas em porta-amostras próprio para o ensaio. As análises foram realizadas no difratômetro da marca Rigaku, modelo Miniflex, disponível no Laboratório de Caracterização de Combustíveis (LACCOM) da PUC-Rio. O índice de cristalinidade (IC) foi determinado através da equação empírica proposta por Segal et al. (1959).

\subsection{8}

\section{Ensaio de tração direta}

O comportamento mecânico das fibras vegetais com e sem tratamento foi determinado através de ensaios de tração direta nas fibras. Os ensaios foram realizados em uma máquina de ensaios universais MTS modelo 810/250 utilizando uma célula de carga de $100 \mathrm{~N}$ e sendo conduzido em uma taxa de deslocamento de $0.1 \mathrm{~mm} / \mathrm{min}$.

As amostras foram preparadas de acordo com ASTM C1557 (2008) com distância entre as garras de $15 \mathrm{~mm}$, sendo selecionados 15 resultados realizados com sucesso. A flexibilidade da máquina foi levada em consideração para medir o módulo de elasticidade da fibra, este calculado no trecho linear da curva tensão-deformação. Este ensaio foi conduzido no Laboratório de Estruturas e Materiais (LEM) da PUC-Rio.

\section{2}

\section{Apresentação e análise dos resultados de caracterização dos reforços estudados}

Neste item são apresentados e analisados os resultados dos ensaios de caracterização dos elementos de reforço dos compósitos solo-fibras vegetais nesta pesquisa. 
Capítulo 4. Caracterização das fibras vegetais (elemento de reforço do compósito)

\subsection{1}

\section{Tratamentos por impregnação}

Das etapas de tratamento por impregnação das fibras foi possível determinar o consumo de solução necessária para o tratamento e o ganho de massa das fibras devido a aderência do tratamento em sua superfície, os valores são apresentados na Tabela 4.2 .

Tabela 4.2: Consumo de solução e ganho de massa das fibras após tratamento

\begin{tabular}{cccc}
\hline \multirow{2}{*}{ Fibra } & Tratamento & $\begin{array}{c}\text { Consumo } \\
\text { da solução } \\
(\%)\end{array}$ & $\begin{array}{c}\text { Ganho de } \\
\text { Massa } \\
(\%)\end{array}$ \\
\hline \multirow{2}{*}{ Sisal } & Sílica & 11.4 & 30.0 \\
& Polímero & 8.2 & 12.0 \\
\hline \multirow{2}{*}{ Curauá } & Sílica & 13.0 & 28.0 \\
& Polímero & 10.0 & 16.0 \\
\hline
\end{tabular}

Analisando estes valores observa-se que a fibra de curauá foi a fibra que mais absorveu os tratamentos, isso provavelmente ocorreu devido sua menor área de seção tranversal, maior superfície específica e um maior número de fibras para um mesmo valor de massa quando comparada com a fibra de sisal que é mais grossa.

O consumo da solução de sílica foi maior do que o consumo da solução de polímero em ambas as fibras, diferença condizente com o ganho de massa das fibras. As duas fibras vegetais estudadas ganharam massa devido a impregnação de sílica e polímero durante a etapa de tratamento. No entanto, o tratamento com sílica resultou em maior ganho de massa. Esse ganho de massa das fibras foi considerado como fator de correção de massa em posteriores análises e ensaios.

\subsection{2}

\section{Capacidade de absorção em água}

Na Figura 4.3 são apresentadas as curvas de ganho de massa vs tempo das fibras com e sem tratamento para efeitos de comparação. As curvas mostram que, em geral, o limite de ganho de massa acontece em aproximadamente 60 min e que após esse tempo não há ganho de massa expressivo para todas as amostras analisadas.

Analisando as fibras sem tratamento, a fibra de curauá foi a que mais absorveu água, com uma absorção de aproximadamente 110\%. As fibras de sisal apresentam uma absorção de água de $70 \%$. O maior capacidade de absorção 
Capítulo 4. Caracterização das fibras vegetais (elemento de reforço do compósito)

em água apresentada pela fibra de curauá está de acordo com o maior consumo de solução apresentada por esta fibra.

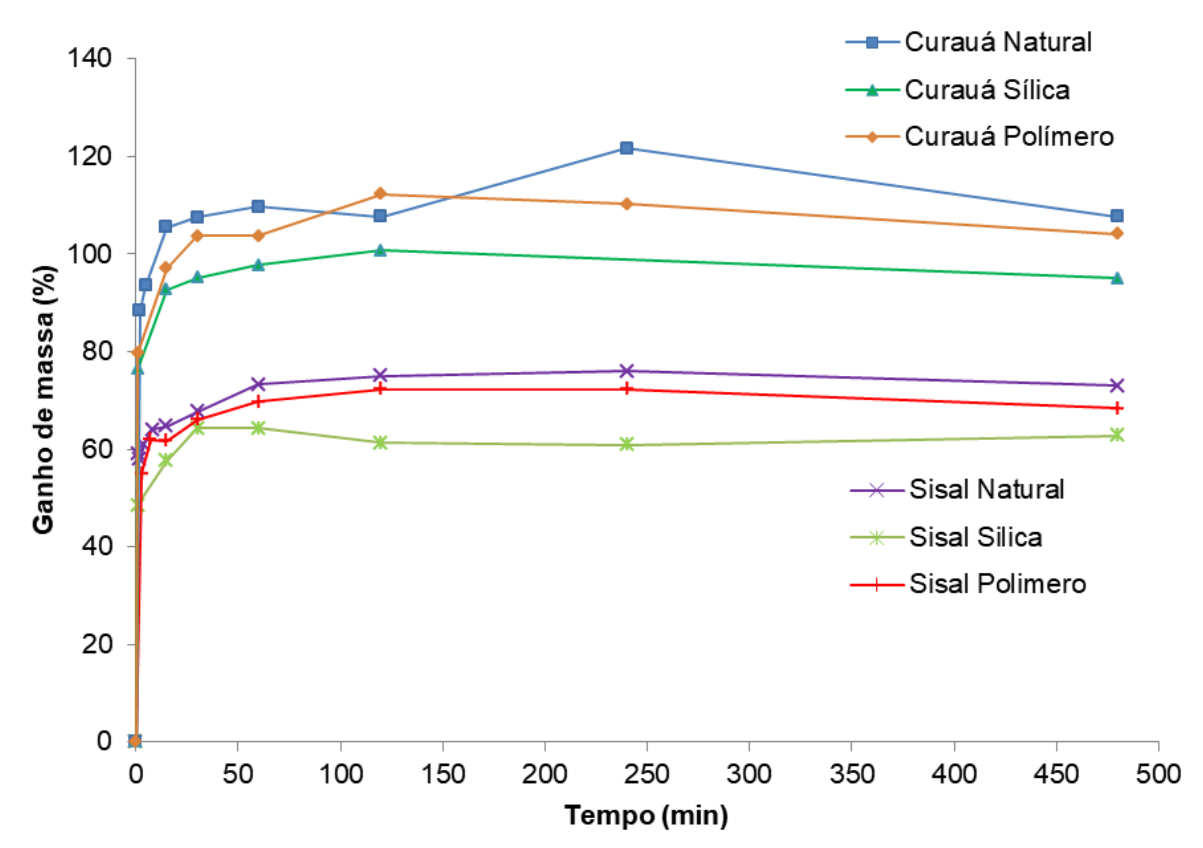

Figura 4.3: Ganho de massa das fibras vegetais com e sem tratamento em água

A maior capacidade de absorção em água apresentada pela fibra de curauá pode ser devido à menor área de seção transversal desta fibra, o que resulta em um maior número destas para uma mesma massa (1g) em comparação com as fibras de sisal que apresentam uma área maior. Assim, quanto menor for a área de seção transversal, maior será a superfície espécifica e maior será a quantidade de fibras necessária resultando em uma maior capacidade de absorção.

Analisando as fibras tratadas, pode-se observar que os dois tratamentos diminuiram a capacidade de absorção de água pelas fibras, devido ao seu comportamento hidrofóbico. No entanto, o tratamento com sílica foi o que melhor contribuiu para esta diminuição. A redução da capacidade de absorção de água foi de aproximadamente $12 \%$.

\section{2 .3}

\section{Análise microestrutural}

Apesar de apresentarem uma mesma estrutura celular (paredes celulares, lamela média e lúmens), as fibras vegetais se diferenciam por aspectos como a área transversal total, o número de fibrocélulas, a espessura das paredes celulares, e quantidade e área de lúmens. Essa variação entre as fibras pode 
Capítulo 4. Caracterização das fibras vegetais (elemento de reforço do compósito)

resultar em um comportamento mecânico diferente (Fidelis et al., 2013). A Figura 4.4 mostra a microestrutura das fibras vegetais estudadas.
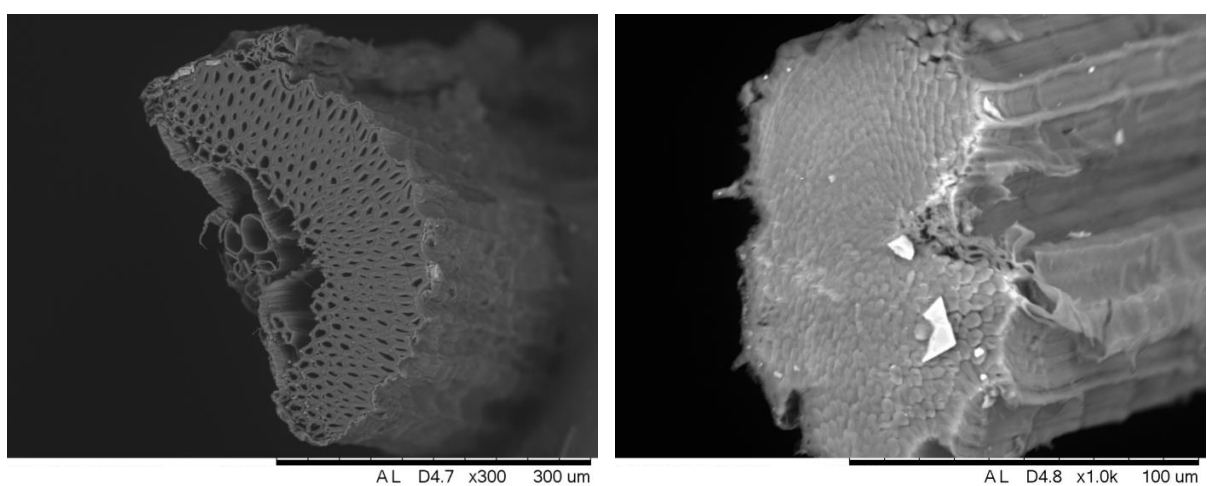

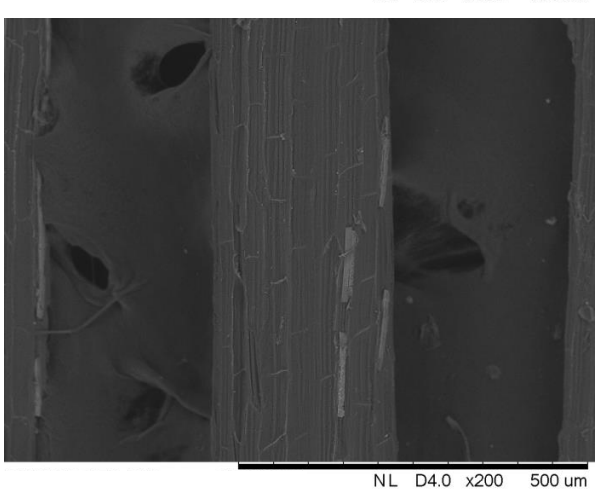

(a)

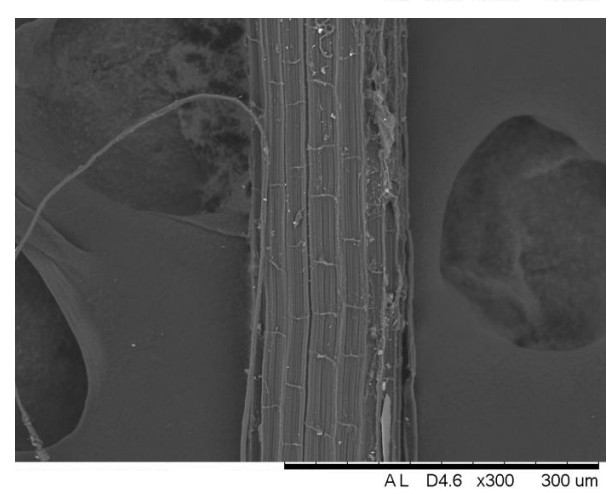

(b)

Figura 4.4: Morfologia da seção transversal e superfície das fibras vegetais sem tratamento: (a) sisal e b) curauá

A análise morfológica indica que a área de seção transversal da fibra de sisal, em torno de $0.023 \mathrm{~mm}^{2}$, é maior que a área de seção transversal da fibra de curauá, em torno de $0.004 \mathrm{~mm}^{2}$, valores semelhantes são encontrados na literatura.

A fibra de sisal apresenta uma morfologia padrão, justamente como descrita anteriormente (Seção 2.3), sendo possível identificar cada uma de suas estruturas (parede primaria, secundária e lúmem), e com os lúmens variando em tamanho, mas geralmente bem definidos, e de tamanhos relevantes, afetando consideravelmente a área transversal efetiva da fibra.

Quanto a morfologia da fibra de curauá apenas é possível identificar as fibrocelulas, e de tão pequenos, a visualização dos lumens fica quase que imperceptível. Na literatura são encontradas imagens de fibras de curauá com outras morfologias. Esta diferença estaria associada ao tipo de espécie, a região da fibra onde é retirada a amostra, do estado de maturação, de fatores ambientais, como solo e clima, região de cultivo, entre outros. 
Capítulo 4. Caracterização das fibras vegetais (elemento de reforço do compósito)

Ambas as fibras analisadas apresentam um número consideravel de fibrocelulas, com curauá apresentando o maior número (300) e sisal (180). Fidelis et al. (2013) observou que a medida que a área interna dos lúmens diminui e a espessura da parede celular secundária aumenta, a resistência da fibra e o módulo de Young's aumentam.

Quanto à superfície longitudinal das fibras, as duas fibras apresentaram similaridades e ambas exibiram uma superfície relativamente lisa.

Análises microestruturais também foram realizadas nas fibras tratadas superficialmente. Buscou-se principalmente identificar os efeitos dos tratamentos por impregnação nas fibras vegetais. A Figura 4.5 mostra a microestrutura das fibras vegetais tratadas.

Comparando a Figura 4.5 com a Figura 4.4 identificou-se que os tratamentos aplicados formaram um filme na superficie das fibras. Enquanto que o tratamento com polímero forma uma camada relativamente lisa, o tratamento com sílica forma uma superfície craquelada.

\subsection{4}

\section{Espectroscopia no Infravermelho por Transformada de Fourier (FTIR)}

Os espectros de FTIR das fibras vegetais com e sem tratamento são mostrados na Figura 4.6. Os espectros mostram modos de vibração característicos das fibras lignocelulósicas de acordo com a literatura (Ferreira, 2016). As fibras vegetais têm como principais constituintes celulose, hemicelulose e lignina, e cada elemento presente tem, na análise de FTIR, uma banda característica na região entre 400 e $4000 \mathrm{~cm}^{-1}$. A maioria dessas bandas é relativa à lignina, celulose e hemiceluloses, correlacionada com grupo Metóxi $\left(\mathrm{CH}_{3} \mathrm{O}^{-}\right)$, e grupos de anéis aromáticos (C=C e C-O-C) (Yang et al., 2007; Sarkanen \& Ludwig, 1987).

A região de picos e vales $\left(1595,1510\right.$ e $\left.1270 \mathrm{~cm}^{-1}\right)$ é atribuída às vibrações de estiramento ou deformação de $\mathrm{C}=\mathrm{O}$ e $\mathrm{C}$ - $\mathrm{O}$ de diferentes grupos presentes na lignina. As bandas em 1460, 1425, 1335, 1220 e $1110 \mathrm{~cm}^{-1}$ são características de vibrações de deformação, flexão ou estiramento de C-H e C-O de muitos grupos em lignina e hidratos de carbono (Ferreira, 2016).

A ligação de hidrogênio intramolecular em um grupo fenólico na lignina é observada em torno de $3568-3577 \mathrm{~cm}^{-1}$. Na celulose, uma vibração de ligação de hidrogênio intramolecular aparece em torno de $3432 \mathrm{~cm}^{-1}$. Outra ligação de hidrogênio intramolecular na celulose normalmente ocorre em $3342 \mathrm{~cm}^{-1}$. As duas bandas características atribuídas aos dois alomorfos de celulose cristalina, celulose $I \alpha$ e celulose $I \beta$, também ocorrem na região de $3220-3280 \mathrm{~cm}^{-1}$ (Popescu et al., 2011). 
Capítulo 4. Caracterização das fibras vegetais (elemento de reforço do compósito)

(a)
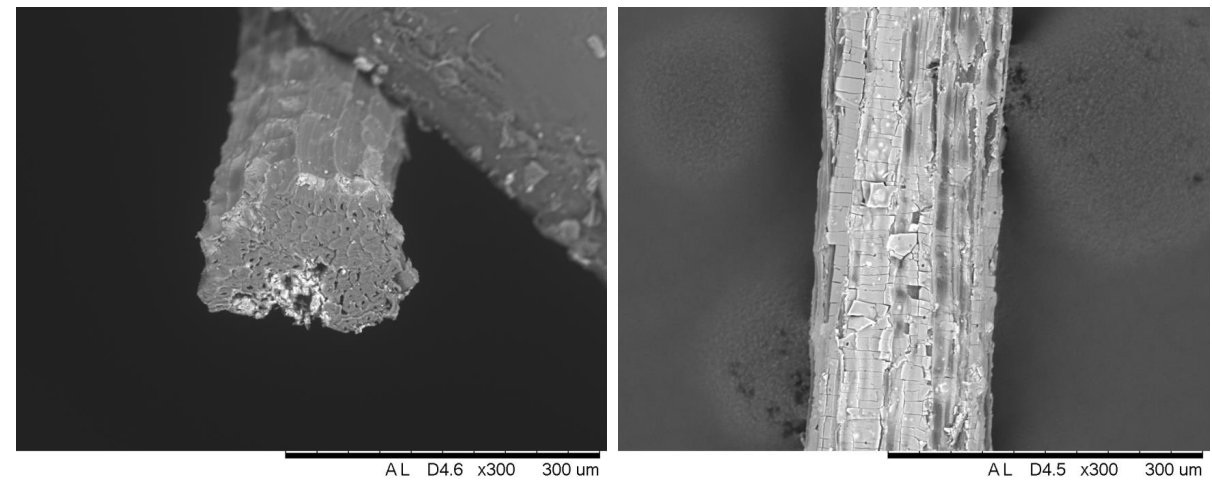

(b)
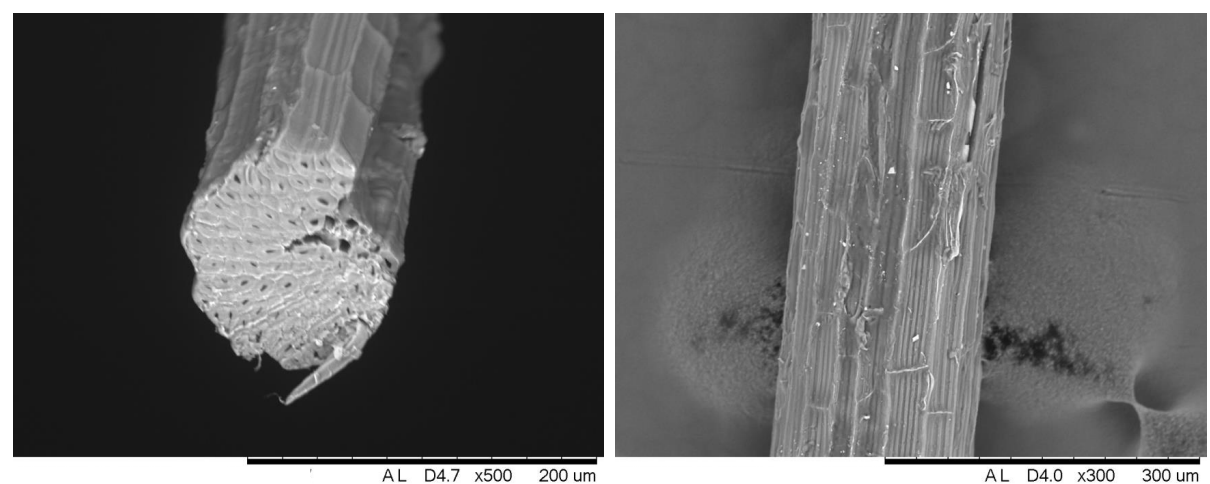

(c)
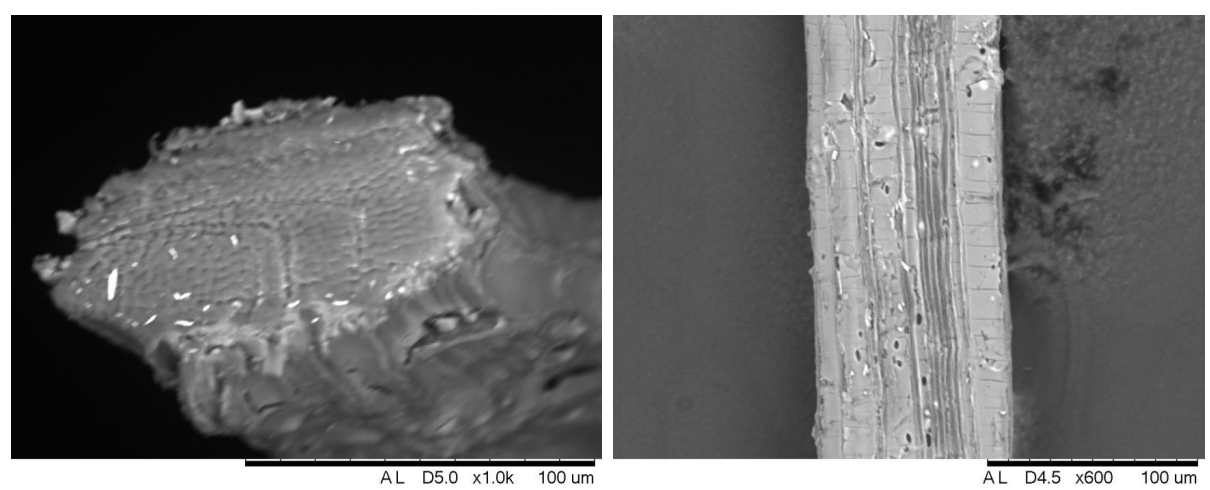

(d)
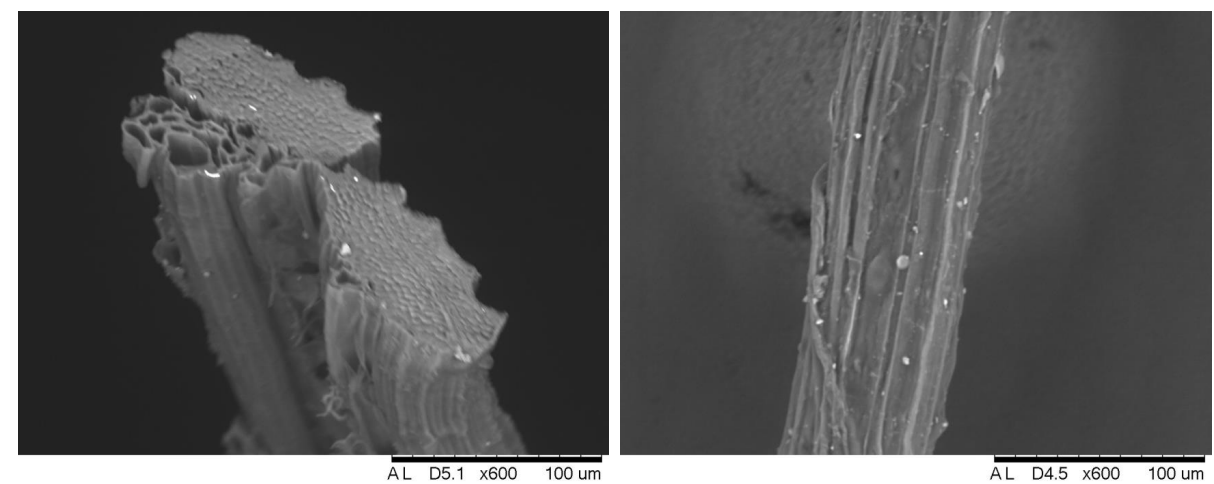

Figura 4.5: Morfologia da seção transversal e superfície das fibras vegetais tratadas superficialmente: (a) sisal-sílica, (b) sisal-polímero, (c) curauá-sílica e (d) curauá-polímero 
Capítulo 4. Caracterização das fibras vegetais (elemento de reforço do compósito)

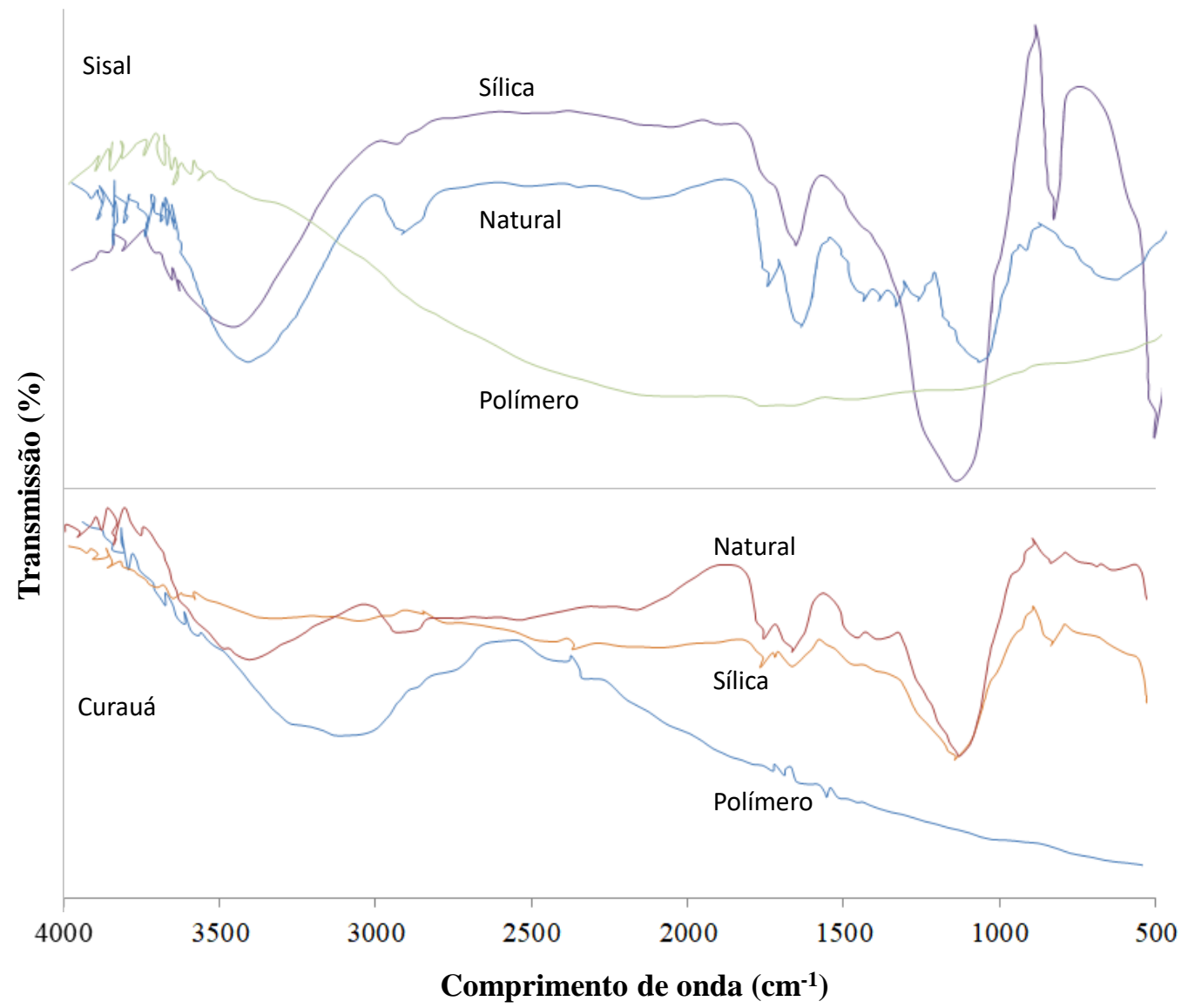

Figura 4.6: Espectro FTIR das fibras vegetais com e sem tratamento

As fibras apresentam bandas semelhante a $1745 \mathrm{~cm}^{-1}$, associado à vibração de estiramento $\mathrm{C}=\mathrm{O}$ das impurezas residuais não-celulósicas. A presença de bandas características em 2916, 2852, 2918 e $2849 \mathrm{~cm}^{-1}$ pode ser atribuída ao maior conteúdo extrativo. Alguns destes compostos contêm grupos metil e metileno (Baiardo et al., 2002).

As fibras apresentam bandas características em $1044 \mathrm{~cm}^{-1}$ atribuído ao estiramento do C-O e à vibração do grupo celulose C-H. Outra banda semelhante observado nas fibras está localizado entre 3221 e $3500 \mathrm{~cm}^{-1}$, atribuído a várias faixas de alongamento de $\mathrm{OH}$ e a ligações de hidrogênio (Yang et al., 2007).

O tratamento com sílica, por ser um material inorgânico e ter bandas características fora da faixa trabalhada, não interferiu nas características dos modos de vibração das fibras lignocelulósicas, diferentemente do que se observa com os espectros de fibras tratadas com polímero. Este, por ser orgânico e ter bandas características na região entre 400 e $4000 \mathrm{~cm}^{-1}$ afetou as os modos de vibração característicos das fibras lignocelulósicas, indicando que 
Capítulo 4. Caracterização das fibras vegetais (elemento de reforço do compósito)

este tratamento impregnou na fibra.

\subsection{5}

\section{Espectrometria de Fluorescência de Raios-X (FRX)}

A composição química das fibras vegetais de sisal e curauá com e sem tratamento é apresentada na Tabela 4.3.

Tabela 4.3: Composição química das fibras vegetais com e sem tratamento

\begin{tabular}{ccccccccc}
\hline \multirow{2}{*}{ Amostra } & \multicolumn{7}{c}{ Constituintes em porcentagens } \\
\cline { 2 - 9 } & $\mathrm{CH}$ & $\mathrm{Al}_{2} \mathrm{O}_{2}$ & $\mathrm{CaO}$ & $\mathrm{SO}_{3}$ & $\mathrm{~K}_{2} \mathrm{O}$ & $\mathrm{Fe}_{2} \mathrm{O}_{3}$ & $\mathrm{CuO}$ & $\mathrm{SiO}_{2}$ \\
\hline Sisal & 99.66 & 0.00 & 0.33 & 0.00 & 0.00 & 0.01 & 0.00 & 0.00 \\
Curauá & 98.00 & 1.81 & 0.16 & 0.02 & 0.01 & 0.01 & 0.00 & 0.00 \\
\hline Sisal-Sílica & 68.36 & 0.00 & 0.37 & 0.00 & 0.00 & 0.02 & 0.01 & 31.25 \\
Sisal-Polímero & 99.03 & 0.00 & 0.16 & 0.10 & 0.19 & 0.01 & 0.00 & 0.52 \\
Curauá-Sílica & 71.22 & 2.14 & 0.08 & 0.00 & 0.00 & 0.02 & 0.01 & 26.53 \\
Curauá-Polímero & 97.04 & 2.02 & 0.06 & 0.09 & 0.23 & 0.01 & 0.00 & 0.54 \\
\hline
\end{tabular}

As fibras utilizadas como elementos de reforço nos compósitos estudados neste trabalho tem origem vegetal, ou seja, orgânica. Os teores dos constituientes das fibras sem tratamento reflete isso ao apresentar valores altos para $\mathrm{CH}$ (orgânicos). Outros constituintes presentes com baixos teores seriam impurezas das fibras.

Nas fibras tratadas, os teores de CH também são elevados, mas sofrem uma leve diminuição quando ambas as fibras passam pelo tratamento com sílica, e um novo contituinte passa a ser detectado que é a sílica $\left(\mathrm{SiO}_{2}\right)$, indicando que este tratamento impregnou na fibra. O polímero é um material orgânico e por isso contribui ainda mais para o teor de $\mathrm{CH}$.

A diminuição do teor de $\mathrm{CH}$ após o tratamento com sílica não significa que o tratamento tenha afetado a parcela orgânica da fibra, apenas significa que no total de amostra analisada, uma parcela passa a ser sílica.

\subsection{6}

\section{Ensaio de Difração de Raios-X (DRX)}

A Figura 4.7 apresenta o difratograma das fibras vegetais sem tratamento. O gráfico mostra picos representando as características do plano cristalino de materiais lignocelulósicos: $15^{\circ}, 23^{\circ}$ e $34^{\circ}$ (Ferreira, 2016). O pico cristalino da celulose está em $2 \Theta=22.5^{\circ}$. Esses espectros são similares aos encontrados na literatura (Fidelis, 2014; Ferreira, 2016). O índice de cristalinidade foi estimado pela relação entre os picos de intensidade máxima $\left(2 \Theta=22.5^{\circ}\right) \mathrm{e}$ mínima $\left(2 \Theta=18^{\circ}\right)$. 
Capítulo 4. Caracterização das fibras vegetais (elemento de reforço do compósito)

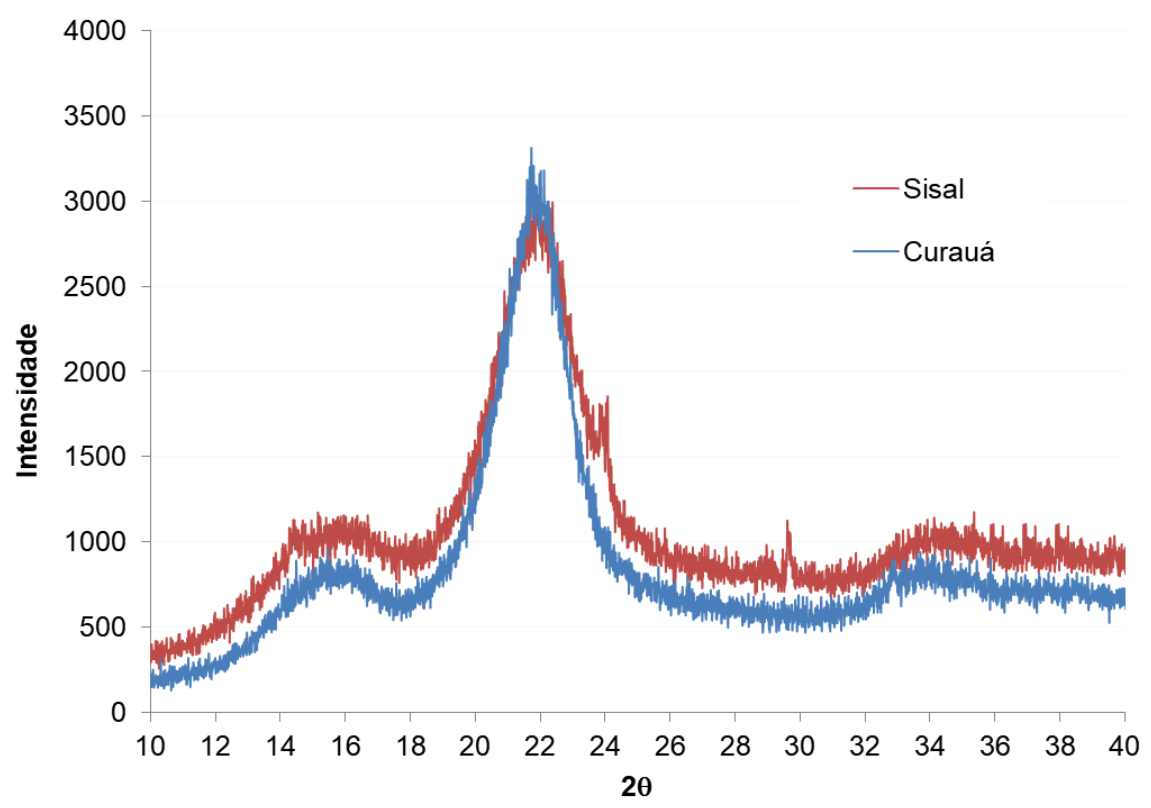

Figura 4.7: Difratogramas das fibras de sisal e curauá.

Os valores para o índice de cristalinidade são $59.38 \%$ e $77.06 \%$ para sisal e curauá, respectivamente. Estes valores estão de acordo com os encontrados na literatura. Segundo Fidelis (2014), quanto maior o índice de cristalinidade maior a resistência mecânica da fibra.

\subsection{7}

\section{Ensaio de tração direta}

A Tabela 4.4 apresenta os resultados dos ensaios de tração direta e seus respectivos desvios-padrões para as duas fibras vegetais estudadas sem tratamento e a Figura 4.8 apresenta as curvas tensão vs deformação dos ensaios e uma reta com a média calculada.

Tabela 4.4: Resultados médios e desvios-padrões dos ensaios de tração nas fibras vegetais sem tratamento superficial

\begin{tabular}{ccccc}
\hline Fibra & $\begin{array}{c}\text { Resistência } \\
\text { à tração } \\
(\mathrm{MPa})\end{array}$ & $\begin{array}{c}\text { Módulo de } \\
\text { elasticidade } \\
(\mathrm{GPa})\end{array}$ & $\begin{array}{c}\text { Deformação } \\
\text { de ruptura } \\
(\%)\end{array}$ & $\begin{array}{c}\text { Área } \\
\text { adotada } \\
\left(\mathrm{mm}^{2}\right)\end{array}$ \\
\hline \multirow{3}{*}{ Sisal } & 270.86 & 5.51 & 5.21 & 0.023 \\
& $(58.47)$ & $(1.34)$ & $(0.81)$ & 0.004 \\
\hline \multirow{2}{*}{ Curauá } & 464.81 & 10.00 & 4.53 & $0.62)$ \\
\hline
\end{tabular}

Vários autores investigaram o comportamento de tração das fibras vegetais. Segundo Fidelis et al. (2013) as grandes discrepâncias existentes entre os 
Capítulo 4. Caracterização das fibras vegetais (elemento de reforço do compósito)

valores relatados para resistência à tração e módulo de Young na literatura estariam associadas as: seções transversais variáveis e irregulares das fibras vegetais, distância entre as garras do equipamento, a taxa de deformação, forma de fixação das amostras ao equipamento, a resolução da precisão da célula de carga e do atuador também podem desempenhar um papel importante nos resultados finais. Finalmente, a metodologia para medir o módulo de elasticidade é de grande importância, uma vez que a flexibilidade da máquina deve ser levada em conta.

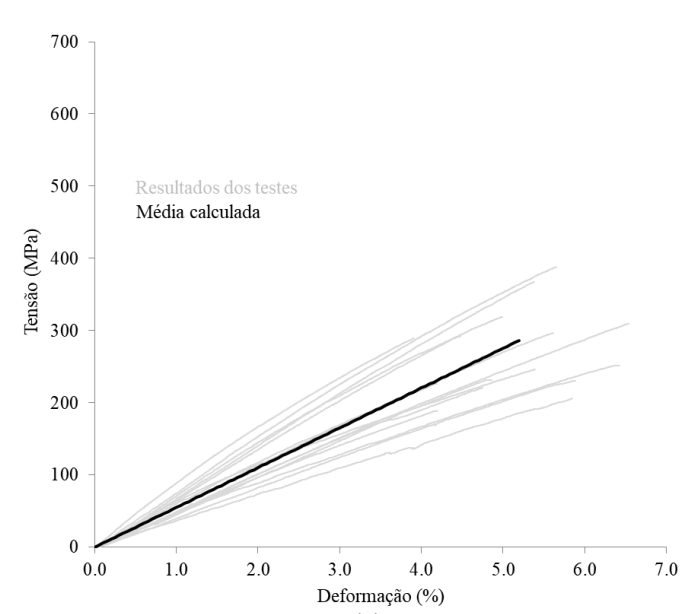

(a)

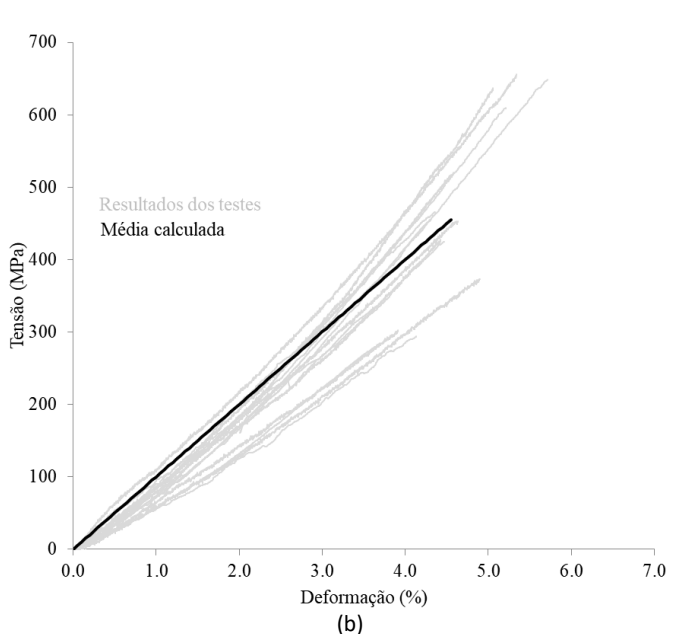

Figura 4.8: Representação gráfica dos 15 resultados dos ensaios de tração e média calculada para as fibras vegetais sem exposição: (a) sisal e (b) curauá

Os valores encontrados para resistência à tração, módulo de elasticidade e deformação na ruptura estão de acordo com os publicados na literatura (Seção 2.3).

Como pode ser observado na Tabela 4.4 e na Figura 4.8, as fibras de sisal e de curauá apresentaram pequena capacidade de deformação, porém alta resistência à tração. De acordo com a literatura, altos valores de resistência à tração e baixa capacidade de deformação podem ser explicados devido ao alto teor de celulose (59-74\%) presente nas fibras estudadas.

Por apresentar estas características, as fibras de curauá e sisal são classificadas como fibras de alto desempenho (Fidelis et al., 2013). A fibra de curauá apresentou o melhor desempenho mecânico com resistência à tração e módulo de elasticidade de 464.81MPa e 10GPa, respectivemente.

O melhor comportamento mecânico apresentado pela fibra de curauá pode ser explicado tanto pela sua morfologia quanto pela sua composição química. Quanto a morfologia por apresentar um menor diâmetro, pela presença de uma pequena área interna dos lumens e maior espessura da parede secun- 
Capítulo 4. Caracterização das fibras vegetais (elemento de reforço do compósito)

dária em sua microestrutura, como apresentado na Seção 4.2.3 e quanto à composição química pelo maior índice de cristalinidade, conforme apresentado na Seção 4.2.6.

As fibras vegetais apresentam curvas de tensão vs deformação de comportamentos diferentes, e esta diferença esta relacionada com o modo de ruptura das fibras. Ferreira (2016) esclarece que as fibras de curauá apresentam um modo de ruptura do tipo fibrilar enquanto que as fibras de sisal apresentam ruptura do tipo granular.

Ensaios de tração direta também foram realizados nas fibras vegetais tratadas com sílica e polímero, com o objetivo de averiguar se o tratamento superficial por impregnação de alguma maneira afeta e/ou prejudica o comportamento mecânico da fibra. A Tabela 4.5 apresenta os resultados dos ensaios de tração direta nas fibras vegetais de sisal e curauá tratadas com sílica e polímero e a Figura 4.9 apresenta as curvas tensão vs deformação dos ensaios e uma reta com a média calculada.

Tabela 4.5: Resultados médios e desvios-padrões dos ensaios de tração nas fibras vegetais tratadas superficialmente

\begin{tabular}{|c|c|c|c|c|c|}
\hline Fibra & Tratamento & $\begin{array}{c}\text { Resistência } \\
\text { à tração } \\
(\mathrm{MPa})\end{array}$ & $\begin{array}{c}\text { Módulo de } \\
\text { elasticidade } \\
(\mathrm{GPa})\end{array}$ & $\begin{array}{c}\text { Deformação } \\
\text { de ruptura } \\
(\%)\end{array}$ & $\begin{array}{c}\text { Área } \\
\text { adotada } \\
\left(\mathrm{mm}^{2}\right)\end{array}$ \\
\hline Sisal & $\begin{array}{c}\text { Sílica } \\
\text { Polímero }\end{array}$ & $\begin{array}{l}325.67 \\
(65.82) \\
331.98 \\
(65.35)\end{array}$ & $\begin{array}{c}5.66 \\
(1.14) \\
5.72 \\
(1.93)\end{array}$ & $\begin{array}{c}5.74 \\
(0.80) \\
5.84 \\
(1.88)\end{array}$ & 0.023 \\
\hline Curauá & $\begin{array}{c}\text { Sílica } \\
\text { Polímero }\end{array}$ & $\begin{array}{c}457.15 \\
(106.86) \\
450.04 \\
(110.13)\end{array}$ & $\begin{array}{c}9.55 \\
(3.57) \\
9.00 \\
(3.01)\end{array}$ & $\begin{array}{c}5.44 \\
(1.06) \\
5.82 \\
(1.03)\end{array}$ & 0.004 \\
\hline
\end{tabular}

Os tratamentos por impregnação com sílica e polímero afetaram levemente os comportamentos mecânicos da fibra de sisal. Os tratamentos realizados proporcionaram melhorais nas fibras de sisal (aumento da resistência à tração, da capacidade de deformação e da deformação de ruptura).

As melhorias observadas nas fibras de sisal podem estar associadas ao filme de proteção na superficie das fibras proporcionadas pelos tratamentos, essa capa estaria uniformizando a superfície, corrigindo imperfeições existentes.

Esta observação não foi identificada na fibra de curauá. Indicando que os tratamentos aplicados encontraram nas fibras de sisal melhores condições de adesão. 


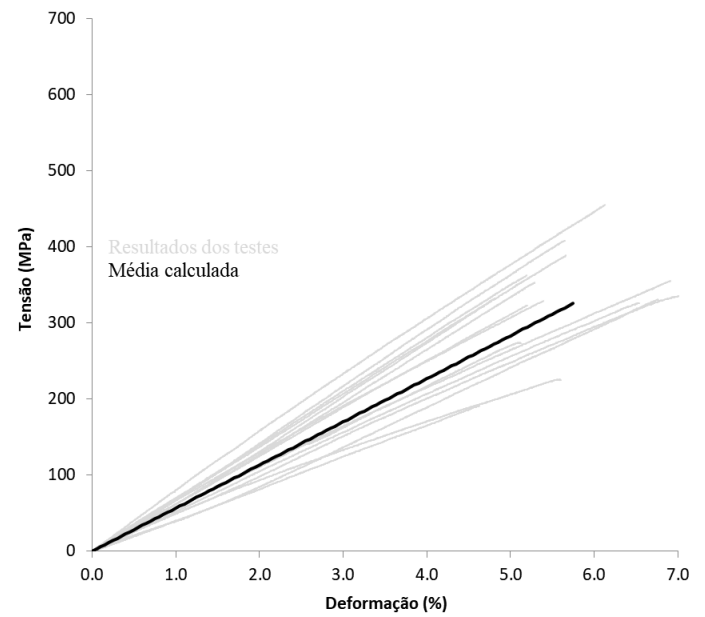

(a)

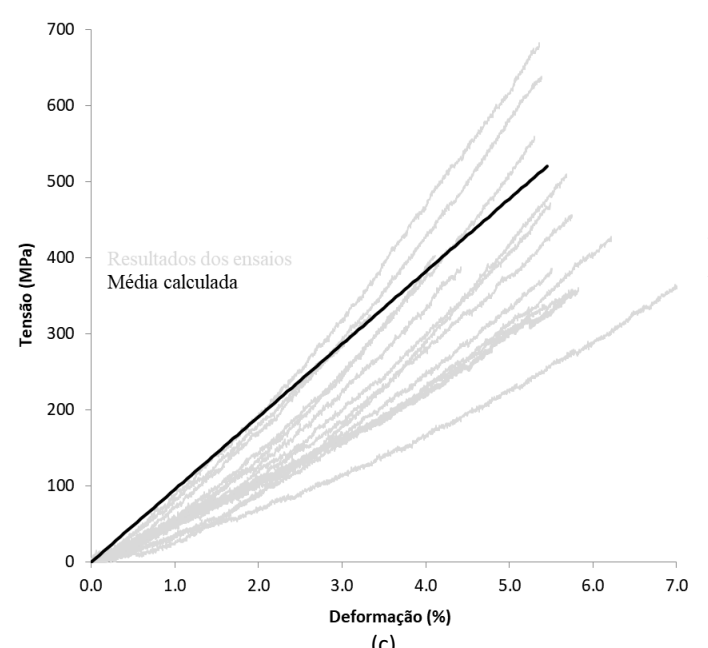

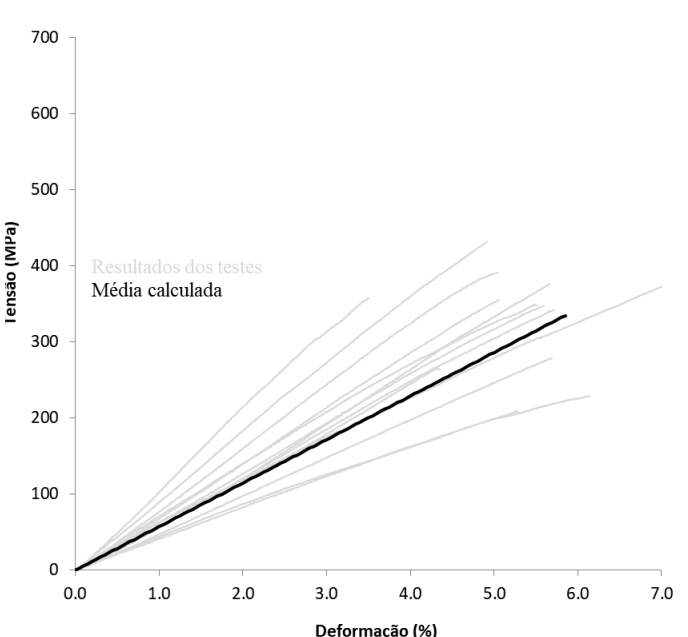

(b)

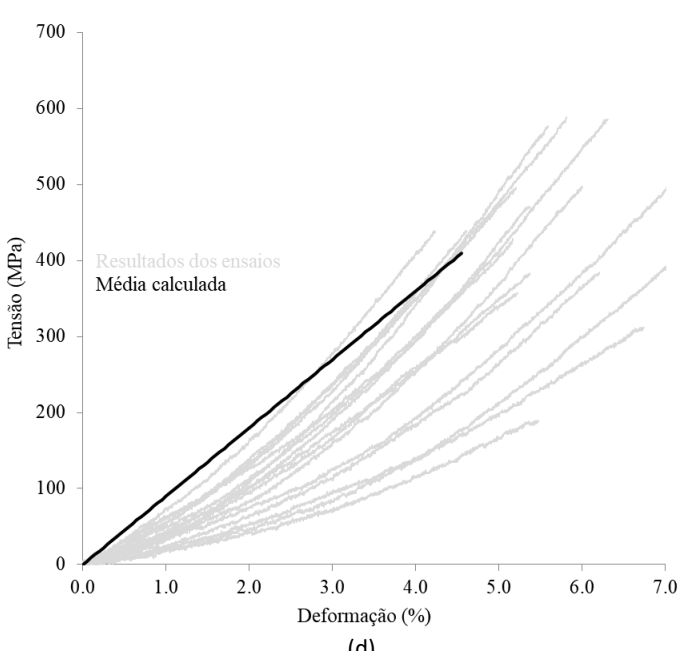

(d)

Figura 4.9: Representação gráfica dos resultados dos ensaios de tração e média calculada para as fibras vegetais tratadas superficialmente: (a) sisal-sílica, (b) sisal-polímero, (c) curauá-sílica e (d) curauá-polímero 


\section{5}

\section{Caracterização mecânica dos compósitos sem exposição}

Neste capítulo são apresentados os resultados e análises dos ensaios triaxiais convencionais realizados em amostras de compósito solo arenoso fibras vegetais aleatoriamente distribuidas no tempo zero (de controle).

O principal objetivo foi investigar e identificar o efeito da adição das fibras vegetais de sisal e curauá sem tratamento nas propriedades mecânicas de um solo arenoso e avaliar se os tratamentos efetuados nas fibras afetam e/ou prejudicam este comportamento mecânico do compósito identificado de modo tal que desqualifique seu emprego.

A seguir são apresentadas as informações para preparação dos corpos de prova de solo reforçado com fibras vegetais, além dos resultados e as respectivas análises.

\section{1 \\ Materiais e métodos}

\subsection{1 \\ Materiais}

A matriz do compósito é o solo arenoso apresentado na Seção 3.

Os elementos de reforço empregados são: fibras de sisal e curauá com e sem tratamento com sílica e com polímero no tempo zero (de controle), ou seja, o contato das fibras com a matriz arenosa ocorreu imediatamente antes da realização do ensaio triaxial, e não houve qualquer contato com agentes climáticos do ambiente exterior ao laboratório. As fibras vegetais com em sem tratamento foram apresentadas na Seção 4.

\section{1 .2}

\section{Moldagem das amostras de compósito solo-fibra}

Para determinar os parâmetros de resistência dos materiais estudados foram realizados ensaios triaxiais convencionais nos compósitos empregando a prensa triaxial disponível no Laboratório de Geotecnia e Meio Ambiente da PUC-Rio que foi apresentada na Seção 3.1.5.1. 
As informações sobre os procedimentos adotados na execução dos ensaios triaxiais foram apresentadas na Seção 3.1.5.4, os parâmetros de moldagem dos corpos de prova e o método utilizado na preparação das amostras para o ensaio triaxial foram apresentados nas Seções 3.1.5.2 e 3.1.5.3, respectivamente.

Os valores de densidade relativa (50\%) e teor de umidade (10\%) adotados para o solo arenoso sem reforço foram os mesmos para o compósito solofibra. Esclarecimentos quanto ao emprego destes valores foram dados na Seção 3.1.5.2. Além dos esclarecimentos feitos, o emprego desta baixa densidade relativa também permitiu com que todos os compósitos, com as várias inclusões utilizadas, alcançassem eficientemente esta densidade relativa.

Fixado o teor de fibra em relação ao peso seco do solo (0.5\%) fixa-se, consequentemente, a massa de fibras a ser adicionada à matriz arenosa em cada corpo de prova. Para a areia empregada nesta pesquisa e as dimensões do molde tri-partido, o valor de massa de fibra a ser adicionado é $0.77 \mathrm{~g}$. $\mathrm{O}$ objetivo inicial era de respeitar este valor em todos os corpos de prova (fibras de sisal e curauá, com e sem tratamento). No entanto, os tratamentos superficiais aplicados nas fibras resultaram em seu ganho de peso, e se esse valor de massa fosse respeitado, o volume de fibras adicionado seria visivelmente diferente. Observado isso, optou-se por corrigir o valor de massa das fibras tratadas levando em consideração o ganho de massa obtido.

Para a mistura dos componentes os mesmos foram adicionados em um recipiente na seguinte sequência: solo, fibras e água. Esta seqüência foi a mais apropriada, pois permitiu a homogeneização dos componentes secos da mistura, antes de ser acrescentada a água. Cada corpo de prova teve uma mistura preparada separadamente e imediatamente antes do ensaio. A mistura foi feita manualmente até ser obtida a homogeneização, verificada visualmente. O exame visual dos espécimes exumados confirmou estarem as misturas de areia e fibras satisfatoriamente uniformes. Durante este processo todas as precauções foram tomadas no sentido de se evitar as perdas de umidade por evaporação.

\section{2}

\section{Apresentação e avaliação dos resultados}

\subsection{1}

\section{Compósitos sem o tratamento das fibras}

Neste item são apresentados e analisados os resultados de seis ensaios triaxiais convencionais, com tensões confinantes de 50,100 e $150 \mathrm{kPa}$, realizados em compósitos de areia reforçada com as fibras sem tratamento e no tempo 
zero (amostras de controle). Buscou-se investigar e identificar o efeito da adição das fibras aleatoriamente distribuídas nas propriedades mecânicas de um solo arenoso.

A Figura 5.1 apresenta em conjunto quatro gráficos obtidos para a série de ensaios triaxiais nos compósitos com as fibras vegetais sem tratameto no tempo zero (amostra de controle): q vs $\varepsilon_{a}$, p' vs q, $\varepsilon_{v}$ vs $\varepsilon_{a}$, e e vs p'. Os valores de índice de vazios após adensamento e ao final do ensaio além da umidade final, são apresentados na Tabela 5.1.
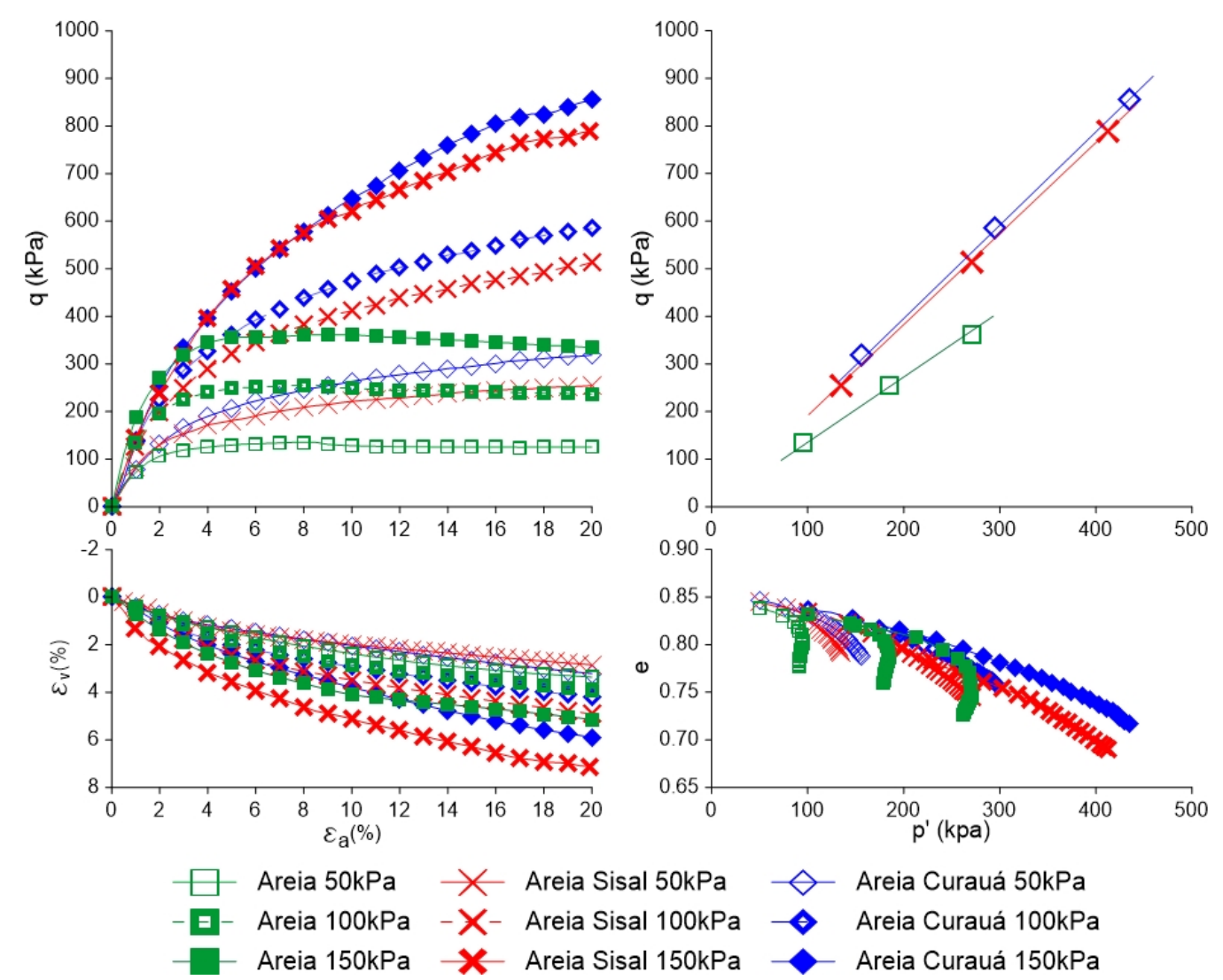

Figura 5.1: Resultados dos ensaios triaxiais convencionais nas amostras de controle

Analisando as curvas q vs $\varepsilon_{a}$ observa-se que, para todos os materiais testados, a resistência aumenta com o incremento da tensão confinante efetiva, e a rigidez inicial dos materiais também aumenta com o aumento da tensão efetiva de confinamento.

É possível observar o nítido acréscimo de resistência ao cisalhamento, sem formação de pico, em função da adição das fibras em relação ao material não reforçado, e que as fibras passam a contribuir logo no início do ensaio, quando a deformação axial é em torno de $2.5 \%$. A partir desta deformação torna-se evidente a diferença de comportamento entre as curvas, e que a contribuição 
da adição fibras permanece visível até a deformação axial limite avaliada de $20 \%$.

Tabela 5.1: Índices físicos após o adensamento e no final do ensaio, dos corpos de prova de compósitos areia-fibras vegetais sem tratamento no tempo zero

\begin{tabular}{ccccc}
\hline & & $\begin{array}{c}\text { Após o } \\
\text { adensamento }\end{array}$ & \multicolumn{2}{c}{$\begin{array}{c}\text { Após o } \\
\text { cisalhamento }\end{array}$} \\
\cline { 3 - 5 } Amostra & $\sigma_{3}^{\prime}$ & $e_{\text {adens }}$ & $e_{\text {final }}$ & $\begin{array}{c}w_{\text {final }} \\
(\%)\end{array}$ \\
\hline \multirow{4}{*}{ Areia-sisal } & 50 & 0.845 & 0.792 & 27.416 \\
& 100 & 0.835 & 0.745 & 25.785 \\
& 150 & 0.819 & 0.690 & 23.873 \\
\hline \multirow{4}{*}{ Areia-curauá } & 50 & 0.847 & 0.788 & 26.278 \\
& 100 & 0.837 & 0.760 & 25.930 \\
& 150 & 0.825 & 0.717 & 25.582 \\
\hline
\end{tabular}

A inclusão de fibras alterou o comportamento mecânico observado na amostra de areia não reforçada. O comportamento elasto-plástico de endurecimento (strain-hardening), ou seja, aumento constante da resistência com o aumento da deformação axial foi observado para todas as tensões de confinamento nas duas amostras analisadas (solo reforçado com fibras de sisal e curauá). Ao comparar os resultados das duas fibras, evidencia-se que as amostras reforçadas com fibra de curauá apresentaram maior resistência ao cisalhamento.

Muitos autores (e.g. Gray \& Maher, 1989; Michalowski \& Čermák, 2003; Festugato, 2008; Ibraim et al., 2010) relatam que fibras com maior fator de forma (L/D) contribuem mais significamente para o aumento da resistência ao cisalhamento do que as fibras com menor fator de forma. Entre as duas fibras utilizadas, a fibra de curauá é a mais fina e, como ambas possuem o mesmo comprimento, a fibra de curauá apresenta maior fator de forma, justificando sua maior resistência ao cisalhamento. Os valores de fator de forma são 146.11 e 352.11 para sisal e curauá, respectivamente.

Um elevado fator de forma contribui duplamente para o aumento da resistência ao cisalhamento do compósito. Quando o fator de forma é alto, a quantidade total de fibras (volume) é relativamente maior com o mesmo teor em peso de fibras, e a área de contato entre as fibras e as partículas do solo também se torna maior, gerando maior atrito (Qu \& Sun, 2016).

Nas curvas $\varepsilon_{v}$ vs $\varepsilon_{a}$, nota-se uma tendência de redução de volume para todas as amostras analisadas e em todas as tensões confinantes empregadas, sendo esta redução tanto maior quanto maior for o valor da tensão confinante. A presença de fibras na matriz arenosa manteve as magnitudes das deformações 
volumétricas similares às identificadas na amostra sem reforço mesmo em altas deformações axiais, indicando que as fibras entrelaçam os grãos da matriz arenosa dificultando sua deformação.

Nas curvas de e vs p', observa-se que a adição de fibras aleatoriamente distribuídas na matriz arenosa alterou o comportamento da variação do índice de vazios com p' durante a fase de cisalhamento identificado nas amostras de areia sem reforço. Para os dois compósitos estudados (areia-sisal e areiacurauá) o comportamento foi similar. Isso pode ser consequência de mudanças na estrutura do material devido à incorporação das fibras.

A Tabela 5.2 apresenta os valores obtidos para tensão desviadora e deformação axial de ruptura, o aumento de resistência de pico obtido pela adição de fibras com relação a amostra de solo sem reforço, a capacidade de absorção de energia $\left(E_{\text {def }}\right)$ e os parâmetros de resistência ao cisalhamento (c' e $\left.\phi^{\prime}\right)$ obtidos para as amostras de controle.

Tabela 5.2: Valores das propriedades mecânicas e dos parâmetros de resistência para os compósitos areia-fibras (amostra de controle)

\begin{tabular}{|c|c|c|c|c|c|c|c|}
\hline Amostra & $\begin{array}{c}\sigma_{3}^{\prime} \\
(\mathrm{kPa})\end{array}$ & $\begin{array}{c}\text { Tensão } \\
\text { desviadora } \\
\text { de ruptura } \\
(\mathrm{kPa})\end{array}$ & $\begin{array}{c}\text { Deformação } \\
\text { axial } \\
(\%)\end{array}$ & $\begin{array}{c}\text { Acréscimo na } \\
\text { resistência } \\
\text { de pico } \\
(\%)\end{array}$ & $\begin{array}{c}E_{\text {def }} \\
\left(\mathrm{kJ} / m^{3}\right)\end{array}$ & $\begin{array}{c}\mathrm{c}^{\prime} \\
(\mathrm{kPa})\end{array}$ & $\begin{array}{l}\phi^{\prime} \\
\left({ }^{\circ}\right)\end{array}$ \\
\hline \multirow{3}{*}{ Areia-Sisal } & 50 & 254.67 & 20.00 & 87.73 & 40.50 & \multirow{3}{*}{0.0} & \multirow{3}{*}{46.29} \\
\hline & 100 & 513.41 & 20.00 & 100.61 & 75.48 & & \\
\hline & 150 & 789.39 & 20.00 & 118.28 & 112.32 & & \\
\hline \multirow{3}{*}{ Areia-Curauá } & 50 & 318.82 & 20.00 & 135.01 & 48.14 & \multirow{3}{*}{10.0} & \multirow{3}{*}{46.73} \\
\hline & 100 & 585.25 & 20.00 & 128.68 & 86.51 & & \\
\hline & 150 & 854.56 & 20.00 & 136.30 & 118.34 & & \\
\hline
\end{tabular}

A Tabela 5.2 quantifica as observações feitas pela Figura 5.1 quanto ao aumento de resistência de pico provocado quando as fibras são adicionadas ao solo arenoso. A adição de fibras de sisal aleatoriamente distribuída na matriz provoca um aumento de resistência de pico de $87-118 \%$ enquanto que a adição de fibras de curauá provoca um aumento de 128-136\%, enfatizando a maior contribuição causado pela adição de fibras de curauá.

Pode ser visto que a capacidade de absorção de energia dos materiais testados aumenta com o incremento da tensão confinante. Para uma mesma tensão confinante, os compósitos de areia reforçados com fibras vegetais, independentemente da fibra adicionada, passam a apresentar quase que o dobro da capacidade de absorção de energia das amostras de areia não reforçada (Tabela 3.4).

As características almejadas com a inclusão de fibras vão depender do tipo de aplicação do compósito, e não necessariamente serão de ganho de resistência. Em um projeto de material sismo-resistente, por exemplo, a ênfase 
será no aumento da capacidade de absorção de energia e ductilidade, assim como diminuição da queda de resistência pós-pico (Martins, 2014).

A adição de fibras de curauá e sisal em solo arenoso causou um aumento no ângulo de atrito $\left(\phi^{\prime}\right)$ e/ou aumento do intercepto coesivo do material. Durante o processo de mistura do solo com fibras distribuídas aleatoriamente, ficou claro que essas fibras proporcionavam um entrelaçamento e de alguma forma ligavam os grãos do solo, promovendo um efeito de ancoragem. Essa observação foi traduzida no aumento dos parâmetros de resistência e comprovada pelos valores obtidos.

Pode-se observar que a mudança verificada nos parâmetros de resistência está de acordo com a mudança no padrão de comportamento tensão desviadora vs deformação axial causado pela adição de fibras vegetais ao solo arenoso no ensaio triaxial.

Consoli et al. (2009a) esclarecem que a melhoria na capacidade de carga da areia pela adição de fibras distribuídas aleatoriamente é resultado da distribuição de carga aplicada em toda a massa do solo através da malha interligada de fibras criada e do atrito de superfície entre fibra/partículas de areia, produzindo assim um aumento na tensão confinante efetiva e consequentemente maior resistência ao cisalhamento.

Isso justificaria um outro ponto observado, que foi a diminuição progressiva da contribuição da fibra na resistência do compósito com o aumento das tensões efetivas inicias, ou seja, as fibras tem um desempenho muito maior na resistência do compósito quando solicitadas a baixas tensões efetivas médias iniciais.

Os resultados obtidos através dos ensaios triaxiais convencionais, realizados em compósitos de areia reforçada com fibras de sisal e curauá sem tratamento superficial, estão condizentes com as informações encontradas na literatura (e.g. Consoli et al., 1999; Donato et al., 2004; Leocádio, 2005; Casagrande, 2005; Festugato, 2008).

Os resultados contribuem para uma melhor interpretação do comportamento mecânico do solo reforçado com fibras vegetais (sisal e curauá), além de mostrar o potencial de utilização deste material como reforço de solos em obras de terra sujeitas a cargas estáticas, oferecendo assim uma alternativa ambientalmente correta que venha a substituir os produtos sintéticos.

\section{2 .2}

\section{Compósitos com o tratamento das fibras}

Neste item são apresentados e analisados os resultados de doze ensaios triaxiais com tensões confinantes de 50, 100 e 150kPa realizados em compósitos 
de areia reforçada com fibras de sisal e curauá tratadas por impermeabilização superficial com sílica e polímero no tempo zero.

A Figura 5.2 apresenta em conjunto quatro gráficos obtidos para a série de ensaios triaxiais nos compósitos com a fibra de sisal tratada com sílica e polímero: q vs $\varepsilon_{a}$, p' vs q, $\varepsilon_{v}$ vs $\varepsilon_{a}$, e e vs p'. Os valores de índice de vazios após adensamento e ao final dos ensaios além da umidade final, são apresentados na Tabela 5.3.
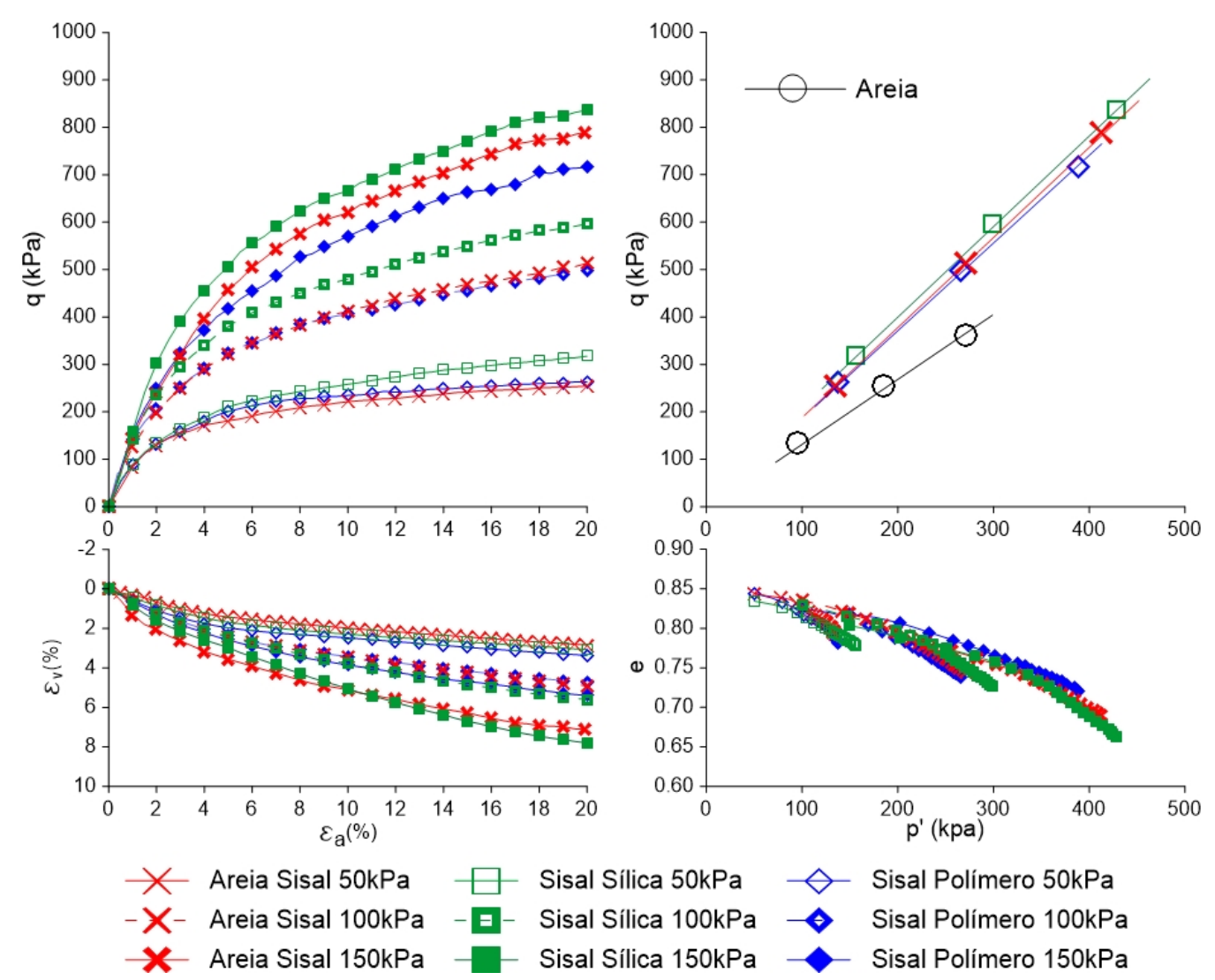

Figura 5.2: Resultados dos ensaios triaxiais convencionais nos compósitos de areia reforçada com fibras de sisal tratadas com sílica e polímero

Analisando as curvas q vs $\varepsilon_{a}$ observa-se que os tratamentos de impregnação ao qual as fibras de sisal foram submetidas não as afetaram de modo que viessem a alterar o comportamento mecânico identificado nos compósitos de controle, ou seja, as fibras de sisal tratadas com sílica e polímero mantiveram o comportamento elasto-plástico de endurecimento ao compósito.

É possível observar que a fibra tratada com sílica promoveu melhorias no comportamento mecânico do compósito em todas as tensões de confinamento analisadas, com valores de tensão desviadora maiores para uma mesma deformação axial. Por outro lado, a fibra tratada com polímero manteve as magnitudes das tensões desviadoras similares as do compósito de controle nas 
tensões de confinamento mais baixas (50 e 100kPa) e diminuiu esses valores na tensão de confinamento de $150 \mathrm{kPa}$.

Tabela 5.3: Índices físicos após o adensamento e no final do ensaio, dos corpos de prova de compósitos de areia reforçada com fibras de sisal tratadas com sílica e polímero

\begin{tabular}{|c|c|c|c|c|c|}
\hline \multirow{2}{*}{ Fibra } & \multirow{2}{*}{ Tratamento } & \multirow{2}{*}{$\sigma_{3}^{\prime}$} & \multirow{2}{*}{$\begin{array}{c}\text { Após o } \\
\text { adensamento } \\
e_{\text {adens }}\end{array}$} & \multicolumn{2}{|c|}{$\begin{array}{c}\text { Após o } \\
\text { cisalhamento }\end{array}$} \\
\hline & & & & $e_{f i n a l}$ & $\begin{array}{c}w_{\text {final }} \\
(\%)\end{array}$ \\
\hline \multirow{6}{*}{ Sisal } & \multirow{3}{*}{ Sílica } & 50 & 0.834 & 0.778 & 26.942 \\
\hline & & 100 & 0.829 & 0.726 & 25.881 \\
\hline & & 150 & 0.803 & 0.663 & 24.780 \\
\hline & \multirow{3}{*}{ Polímero } & 50 & 0.844 & 0.782 & 25.267 \\
\hline & & 100 & 0.825 & 0.738 & 23.604 \\
\hline & & 150 & 0.818 & 0.720 & 23.402 \\
\hline
\end{tabular}

A melhoria constatada no que se refere à tensão de pico nos compósitos com fibras tratadas com sílica, pode ser resultado de alterações na interface fibra-matriz (i.e. aumento da rugosidade superficial) proporcionando um maior efeito de aderência, já que não foram identificadas mudanças ocasionadas na fibra (resistência à tração, módulo e a deformação) devido ao tratamento.

A diminuição da contribuição das fibras de sisal quando tratadas com polímero no comportamento mecânico do compósito na tensão de confinamento de $150 \mathrm{kPa}$ pode também ser resultado de mudanças na interface fibra-matriz. Um outro ponto seria devido à maior viscosidade e efeito de cola do polímero, que mesmo tendo sido diluído em água destilada, resultou em fibras grudadas, que vieram a formar uma única unidade, em fibras mais rígidas ao toque dos dedos, e em fibras, que mesmo após sua secagem, apresentaram uma superfície pegajosa/adesiva (esperava-se que isso fosse aumentar a adesão fibra-matriz refletindo de um modo positivo no comportamento tensão-deformação). A união de fibras aumenta o diâmetro do filamento afetando, consequentemente, o fator de forma (L/D) já discutido anteriormente, com a diminuição do fator de forma diminui também a contribuição da fibra no aumento da resistência ao cisalhamento.

Vale ressaltar que todo o cuidado foi tomado para identificar e descartar as uniões de fibras no momento da moldagem, mas devido à variabilidade dimensional natural das fibras, as de menores diâmetros podem ter se unido e passado como uma fibra mais grossa.

Nas curvas $\varepsilon_{v}$ vs $\varepsilon_{a}$, nota-se que a tendência de redução de volume permaneceu e que a presença de fibras de sisal tratadas manteve as magnitudes 
das deformações volumétricas similares as identificadas na amostra de controle.

Nas curvas de e vs p', nota-se que a adição de fibras tratadas não alterou o comportamento da variação do índice de vazios com p' durante a fase de cisalhamento identificado nas amostras de controle.

A Figura 5.3 apresenta em conjunto quatro gráficos obtidos para a série de ensaios triaxiais nos compósitos com a fibra de curauá tratada com sílica e polímero: q vs $\varepsilon_{a}$, p' vs q, $\varepsilon_{v}$ vs $\varepsilon_{a}$, e e vs p'. Os valores de índice de vazios após adensamento e ao final do ensaio além da umidade final, são apresentados na Tabela 5.4 .

Analisando as curvas q vs $\varepsilon_{a}$ observa-se que o tratamento de impregnação por sílica a qual a fibra de curauá foi submetida não a afetou de modo que viesse a alterar o comportamento mecânico identificado no compósito de controle, ou seja, a fibra de curauá tratada com sílica assegurou o comportamento elastoplástico de endurecimento ao compósito, e que em geral a magnitude dos valores de tensão desviadora permaneceu similar aos do compósito de controle.
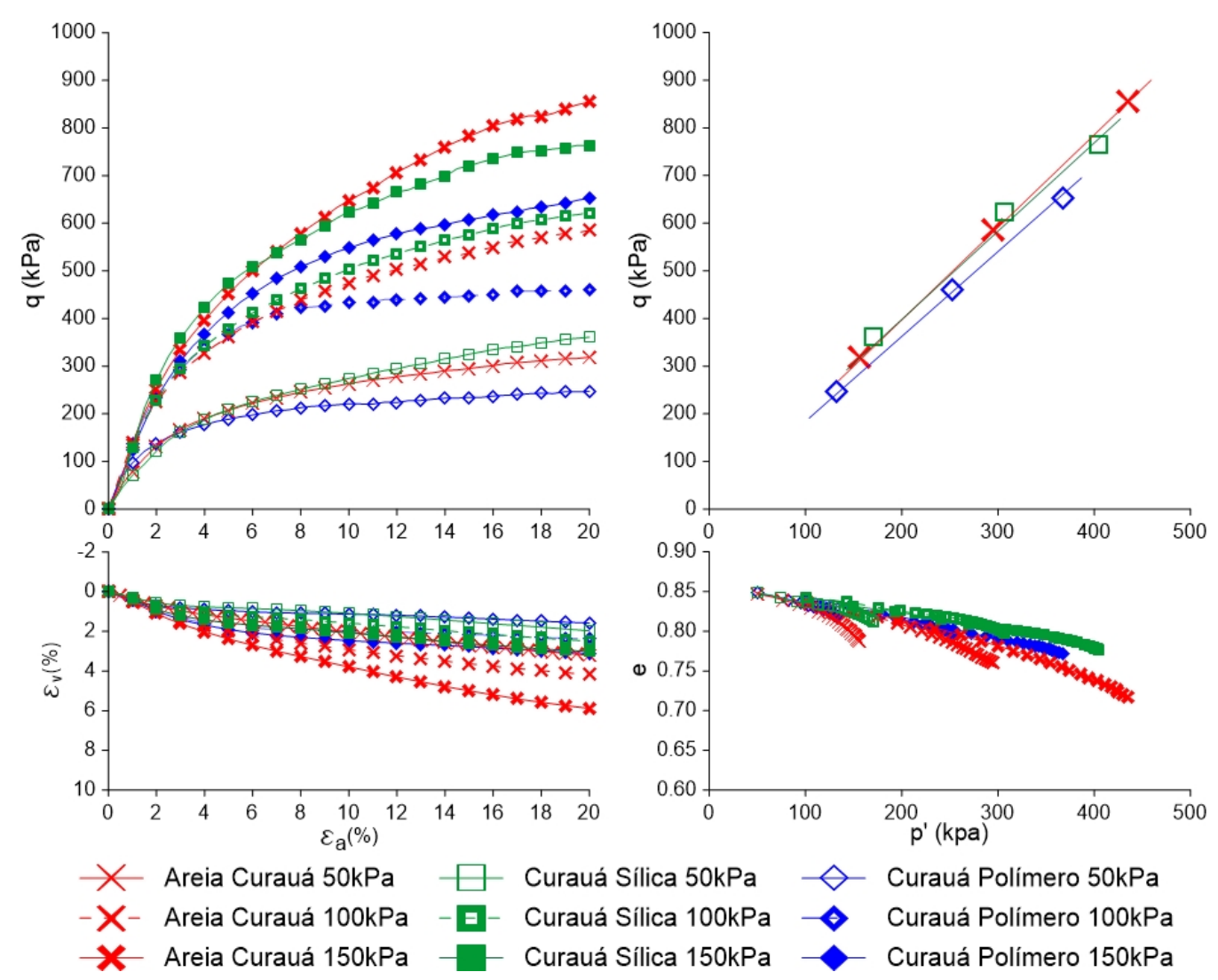

Figura 5.3: Resultados dos ensaios triaxiais convencionais nos compósitos de areia reforçada com fibras de curauá tratadas com sílica e polímero

Por outro lado, a fibra de curauá tratada com polímero afetou de modo significativo o comportamento mecânico identificado no compósito de controle em todas as tensões de confinamento analisadas, deixando de apresentar 
o comportamento elasto-plástico de endurecimento. Em todas as tensões de confinamento analisadas, as magnitudes das tensões desviadoras foram menores do que as identificadas no compósito de controle.

Tabela 5.4: Índices físicos após o adensamento e no final do ensaio, dos corpos de prova de compósitos de areia reforçada com fibras de curauá tratadas com sílica e polímero

\begin{tabular}{|c|c|c|c|c|c|}
\hline \multirow[b]{2}{*}{ Fibra } & \multirow[b]{2}{*}{ Tratamento } & \multirow[b]{2}{*}{$\sigma_{3}^{\prime}$} & $\begin{array}{c}\text { Após o } \\
\text { adensamento }\end{array}$ & \multicolumn{2}{|c|}{$\begin{array}{c}\text { Após o } \\
\text { cisalhamento }\end{array}$} \\
\hline & & & $e_{\text {adens }}$ & $e_{\text {final }}$ & $\begin{array}{c}w_{\text {final }} \\
(\%)\end{array}$ \\
\hline \multirow{6}{*}{ Curauá } & \multirow{3}{*}{ Sílica } & 50 & 0.848 & 0.812 & 26.992 \\
\hline & & 100 & 0.843 & 0.797 & 26.505 \\
\hline & & 150 & 0.831 & 0.776 & 25.815 \\
\hline & \multirow{3}{*}{ Polímero } & 50 & 0.848 & 0.819 & 26.381 \\
\hline & & 100 & 0.840 & 0.796 & 26.398 \\
\hline & & 150 & 0.828 & 0.771 & 25.338 \\
\hline
\end{tabular}

A viscosidade e o efeito de cola do polímero afetaram mais significamente a fibra de curauá do que a fibra de sisal provavelmente devido a sua menor área de seção transversal. As etapas de tratamento superficial por impregnação foram as mesmas nas duas fibras trabalhadas, mas por ter a fibra de curauá maior grau de finura, talvez essas etapas não tenham sido o suficiente para evitar a união de uma ou mais fibras formando um único filamento, diminuindo assim a contribuição das fibras no aumento da resistencia ao cisalhamento.

Apesar de ter sido identificado que o tratamento por impregnação com polímero prejudicou o comportamento mecânico identificado nas amostras de controle, optou-se por analisar seu efeito como impermeabilizante na durabilidade do compósito.

Nas curvas $\varepsilon_{v}$ vs $\varepsilon_{a}$, nota-se que a tendência de redução de volume permaneceu no entanto, a presença de fibras de curauá tratadas diminuiu a magnitude das deformações volumétricas em relação aos valores da amostra de controle em todas as tensões de confinamento estudadas. Essa constatação indica que as fibras tratadas dificultaram ainda mais a deformação da matriz durante o cisalhamento.

Este enrijecimento proporcionado pelas fibras tratadas fez com que as curvas de e vs p' apresentassem um comportamento diferente daqueles identificados tanto na amostra arenosa quanto nos compósitos areia-fibra de curauá sem tratamento.

A Tabela 5.5 quantifica as observações feitas pelas Figuras 5.2 e 5.3 . Nela são apresentados os valores obtidos para tensão desviadora e deformação 
axial de ruptura, o aumento de resistência de pico obtido pela adição de fibras tratadas com relação a amostra arenosa, a capacidade de absorção de energia $\left(E_{d e f}\right)$ e os parâmetros de resistência ao cisalhamento (c' e $\left.\phi^{\prime}\right)$ obtidos.

Tabela 5.5: Valores das propriedades mecânicas e dos parâmetros de resistência para os compósitos areia-fibras tratadas no tempo zero

\begin{tabular}{|c|c|c|c|c|c|c|c|c|}
\hline Fibra & Tratamento & $\begin{array}{c}\sigma_{3}^{\prime} \\
(\mathrm{kPa})\end{array}$ & $\begin{array}{c}\text { Tensão } \\
\text { desviadora } \\
\text { de ruptura } \\
(\mathrm{kPa})\end{array}$ & $\begin{array}{c}\text { Deformação } \\
\text { axial } \\
(\%)\end{array}$ & $\begin{array}{c}\text { Acréscimo na } \\
\text { resistência } \\
\text { de pico } \\
(\%)\end{array}$ & $\begin{array}{c}E_{\text {def }} \\
\left(\mathrm{kJ} / m^{3}\right)\end{array}$ & $\begin{array}{c}\mathrm{c}^{\prime} \\
(\mathrm{kPa})\end{array}$ & $\begin{array}{l}\phi^{\prime} \\
\left(^{\circ}\right)\end{array}$ \\
\hline \multirow{6}{*}{ Sisal } & \multirow{3}{*}{ Sílica } & 50 & 317.54 & 20.00 & 134.06 & 47.86 & \multirow{3}{*}{12.88} & \multirow{3}{*}{46.21} \\
\hline & & 100 & 596.24 & 20.00 & 132.98 & 89.11 & & \\
\hline & & 150 & 836.10 & 20.00 & 131.19 & 131.92 & & \\
\hline & \multirow{3}{*}{ Polímero } & 50 & 263.18 & 20.00 & 93.99 & 42.85 & \multirow{3}{*}{8.41} & \multirow{3}{*}{43.92} \\
\hline & & 100 & 498.33 & 20.00 & 94.72 & 74.78 & & \\
\hline & & 150 & 716.00 & 20.00 & 97.98 & 103.78 & & \\
\hline \multirow{6}{*}{ Curauá } & \multirow{3}{*}{ Sílica } & 50 & 360.75 & 20.00 & 165.92 & 50.91 & \multirow{3}{*}{38.19} & \multirow{3}{*}{42.22} \\
\hline & & 100 & 621.98 & 20.00 & 143.04 & 91.48 & & \\
\hline & & 150 & 763.65 & 20.00 & 111.16 & 112.68 & & \\
\hline & \multirow{3}{*}{ Polímero } & 50 & 247.24 & 20.00 & 82.25 & 40.58 & \multirow{3}{*}{10.53} & \multirow{3}{*}{42.06} \\
\hline & & 100 & 459.43 & 20.00 & 79.52 & 77.28 & & \\
\hline & & 150 & 652.89 & 20.00 & 80.53 & 97.57 & & \\
\hline
\end{tabular}

Analisando os valores de tensão desviadora de ruptura, aumento de resistência de pico obtido pela adição de fibras e $E_{\text {def }}$ e comparando com a Tabela 5.2 é possivel observar que, dentre os dois tratamentos superficiais empregados, o tratamento de ambas as fibras (sisal e curauá) com sílica chegou a proporcionar melhorias no comportamento mecânico do compósito.

Ambos os tratamentos aplicados afetaram os parâmetros de resistência dos compósitos ao resultar, em geral, na redução do ângulo de atrito e/ou manifestação de uma parcela do intercepto coesivo. No entanto, ambos os valores de c' e $\phi^{\prime}$ permaneceram maiores que os observados na amostra arenosa sem reforço (Tabela 3.4). 


\section{6 \\ Durabilidade das fibras submetidas ao envelhecimento natural}

Neste capítulo são apresentados os resultados e análises dos ensaios realizados nas fibras vegetais de sisal e curauá, com e sem tratamento, submetidas à exposição ao solo e aos agentes climáticos diversos por 8 meses.

O principal objetivo foi investigar e identificar os efeitos dos agentes do envelhecimento natural sobre a morfologia, composição química e comportamento mecânico das fibras vegetais sem tratamento, bem como avaliar a atuação dos tratamentos superficiais empregados na durabilidade destas fibras.

Como a degradação das fibras poderá afetar os parâmetros de resistência do compósito, ensaios e análises da perda de massa das fibras, MEV, FTIR, FRX e tração direta nas fibras foram realizados nas fibras após cada período de exposição (60, 120 e 240 dias), para buscar explicar as variações nos resultados dos compósitos obtidos.

\section{1 \\ Materiais e Métodos}

\subsection{1}

Moldagem das amostras de compósito solo-fibra expostas às condições ambientais ao longo do tempo

Para avaliar a influência que as condições ambientais inerentes à função de reforço de solo têm na degradação de fibras naturais vegetais, foram concebidos dois cenários de análise: solo reforçado com fibras no tempo zero, sem exposição aos agentes climáticos diversos (de controle), apresentado na Seção 5, e solo reforçado com fibras exposto às condições ambientais diversas ao longo do tempo (Figura 6.1).

Para o cenário relativo às condições ambientais, uma série de tubos bipartidos com $11 \mathrm{~cm}$ de altura e $4.7 \mathrm{~cm}$ de diâmetro e um geotextil aderido na sua base foram confeccionados para que pudessem conter o solo reforçado com fibras a ser exposto.

Para cada compósito exposto (solo arenoso reforçado com fibras de sisal com e sem tratamento (com sílica e polímero) e solo arenoso reforçado com fibras de curauá com e sem tratamento (com sílica e polímero)) foram confeccionados cinco tubos para cada tempo de exposição. 


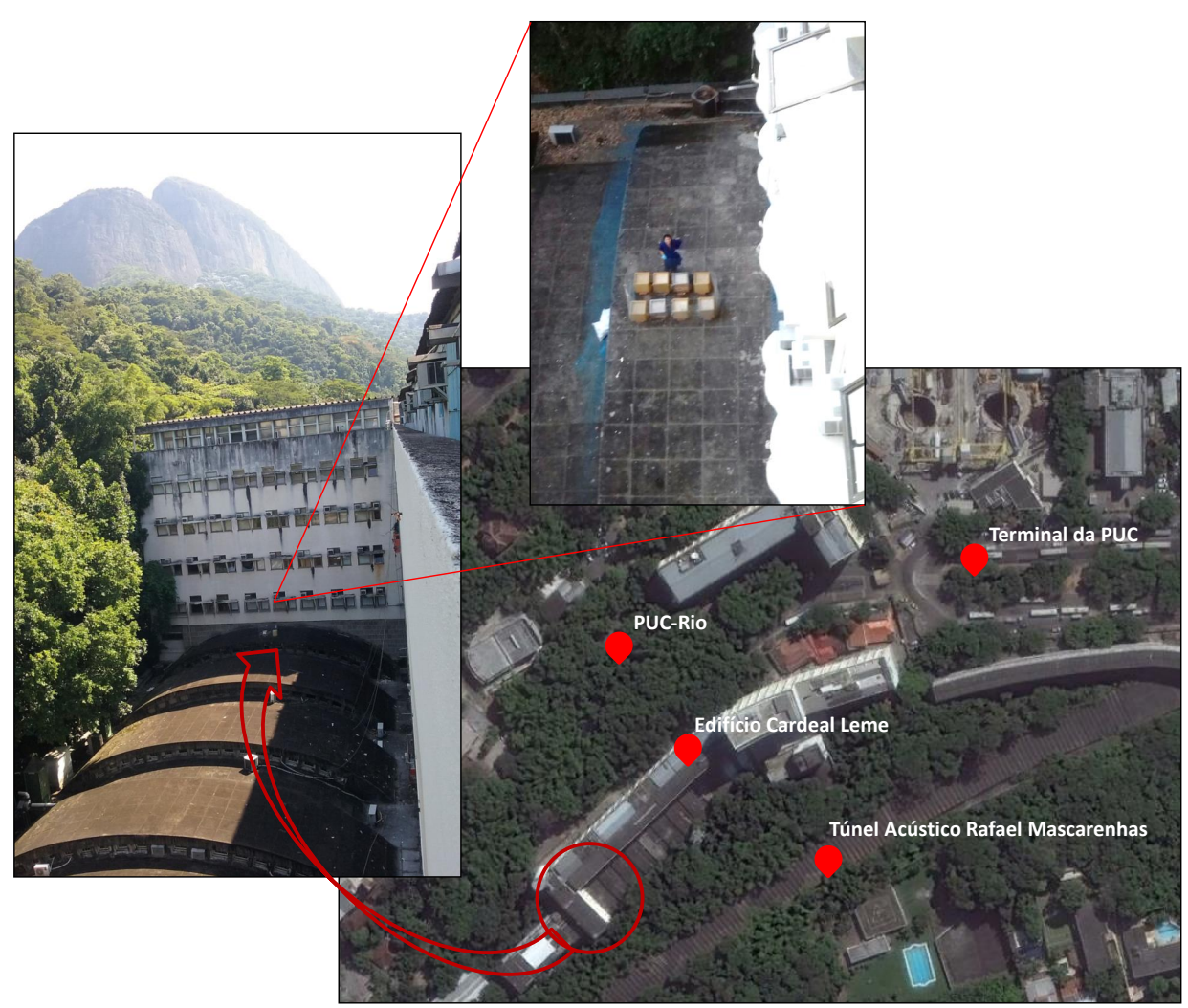

Figura 6.1: Local escolhido para expor as amostras aos agentes climáticos

O compósito exposto foi preparado empregando os mesmos parâmetros de moldagem das amostras de controle (Seções 3.1.5.2 e 5.1.2). Dentro destes tubos bipartidos, as amostras foram compactadas manualmente em cinco camadas, controlando o peso da mistura adicionada e a altura das camadas de forma a obter a densidade relativa desejada (Figura 6.2). Cada camada desta amostra continha exatamente a quantidade de material necessária para cada camada do corpo de prova submetido ao ensaio triaxial.

Uma série de caixas de dimensão $35 \times 35 \times 35 \mathrm{~cm}$ foi confeccionada para conter uma espessa camada de areia e sobre esta camada ficarem os tubos contendo os compósitos a serem expostos ao tempo. Estas caixas ficavam suspensas em $5 \mathrm{~cm}$ do solo e a face inferior delas apresentavam furos para permitir a drenagem da água das chuvas. Dessa maneira, a água das chuvas percolavam através dos compósitos contidos nos tubos, não occorendo o seu acumulo.

No ambiente exterior, os compósitos ficaram expostos por um período de de oito meses (iniciando em janeiro/fevereiro - verão no hemisfério sul), sendo realizados ensaios nos tempos 60, 120 e 240 dias com o objetivo traçar curvas que relacionem as variáveis resistência e tempo. 

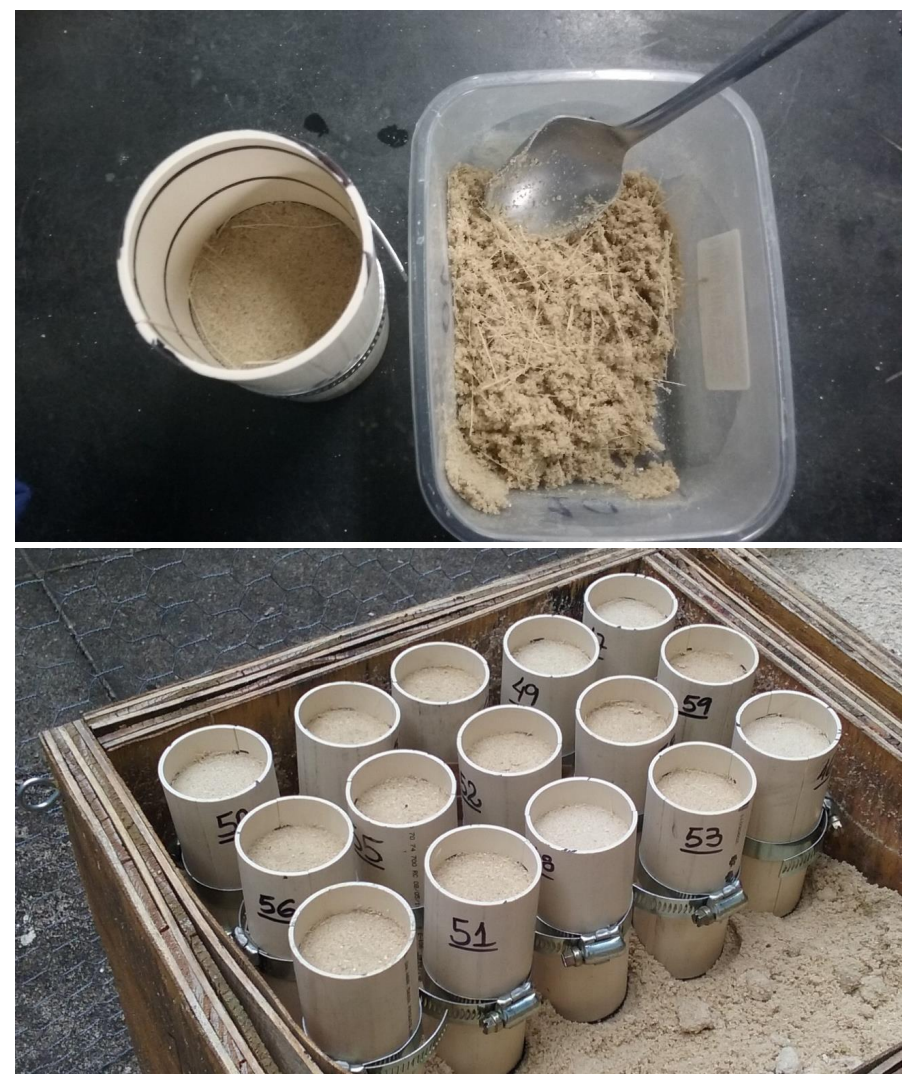

Figura 6.2: Moldagem das amostras de compósito solo-fibra expostas às condições ambientais

Estas amostras foram sujeitas à ação de diversos agentes climáticos como variações de temperatura do solo, fruto não só da transição do dia para a noite, mas também de estações, variações de umidade do solo, resultantes da precipitação, e também da incidência de radiação solar, que influencia o processo de biodegradação das fibras. As variáveis meteorológicas (temperatura, umidade relativa do ar e precipitação) foram obtidas pelo Sistema Alerta Rio da Prefeitura do Rio de Janeiro, estação Jardim Botânico (Figura 6.3). 


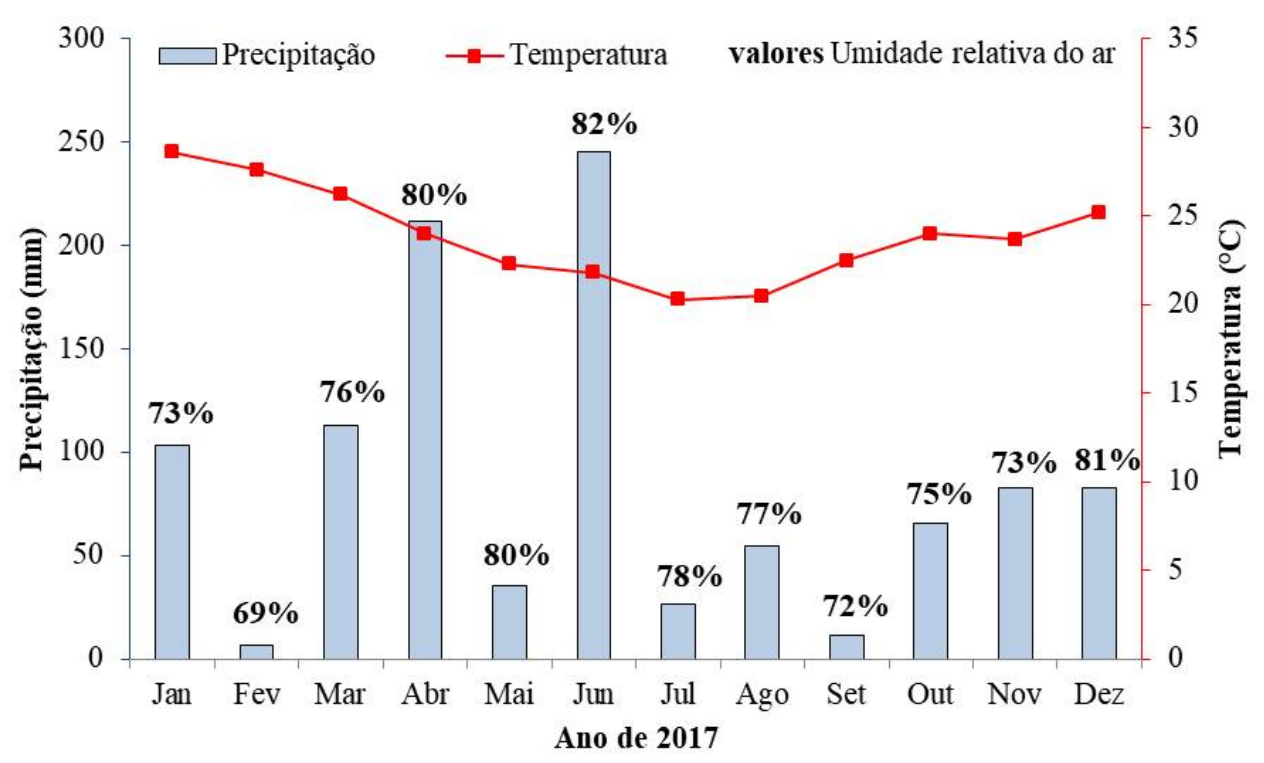

Figura 6.3: Parâmetros meteorológicos do ano de 2017: temperatura média, umidade relativa média do ar e precipitação

\subsection{2}

\section{Preparo das amostras expostas às condições ambientais ao longo do tempo para ensaios e análises}

Após cada período de exposição, três tubos de um mesmo compósito eram retirados do ambiente exterior (um para cada tensão confinante avaliada). As etapas seguintes consistiam na retirada do molde bipartido, separação das camadas (Figura 6.4) e acondicionamento de cada uma das cinco camadas em cápsulas separadas. O compósito localizado nas três camadas centrais de cada tubo era então separado para ser submetido ao ensaio triaxial convencional. As camadas superiores e inferiores dessas amostras eram preparadas e acondicionadas para análise da durabilidade das fibras.

As camadas do topo e da base de dois dos três tubos retirados do telhado eram lavadas em peneiras para retirar as fibras da matriz arenosa, etapa delicada onde não foram medidos esforços para que fibras não fossem perdidas durante a lavagem. Após esta etapa, as fibras retidas na peneira foram secas em estufa $\left(60^{\circ} \mathrm{C}\right)$ e posteriormente preparadas para os ensaios e análises de perda de massa, MEV, FTIR, FRX e tração direta.

Os equipamentos e métodos de preparo das amostras para os ensaios e análise de MEV, FTIR, FRX e tração direta foram os mesmos adotados para a caracterização dos elementos de reforço sem exposição (tempo zero), apresentados na Seção 4.1. O levantamento da perda de massa das fibras era obtido pesando-se as fibras remanescentes após cada período de exposição. 

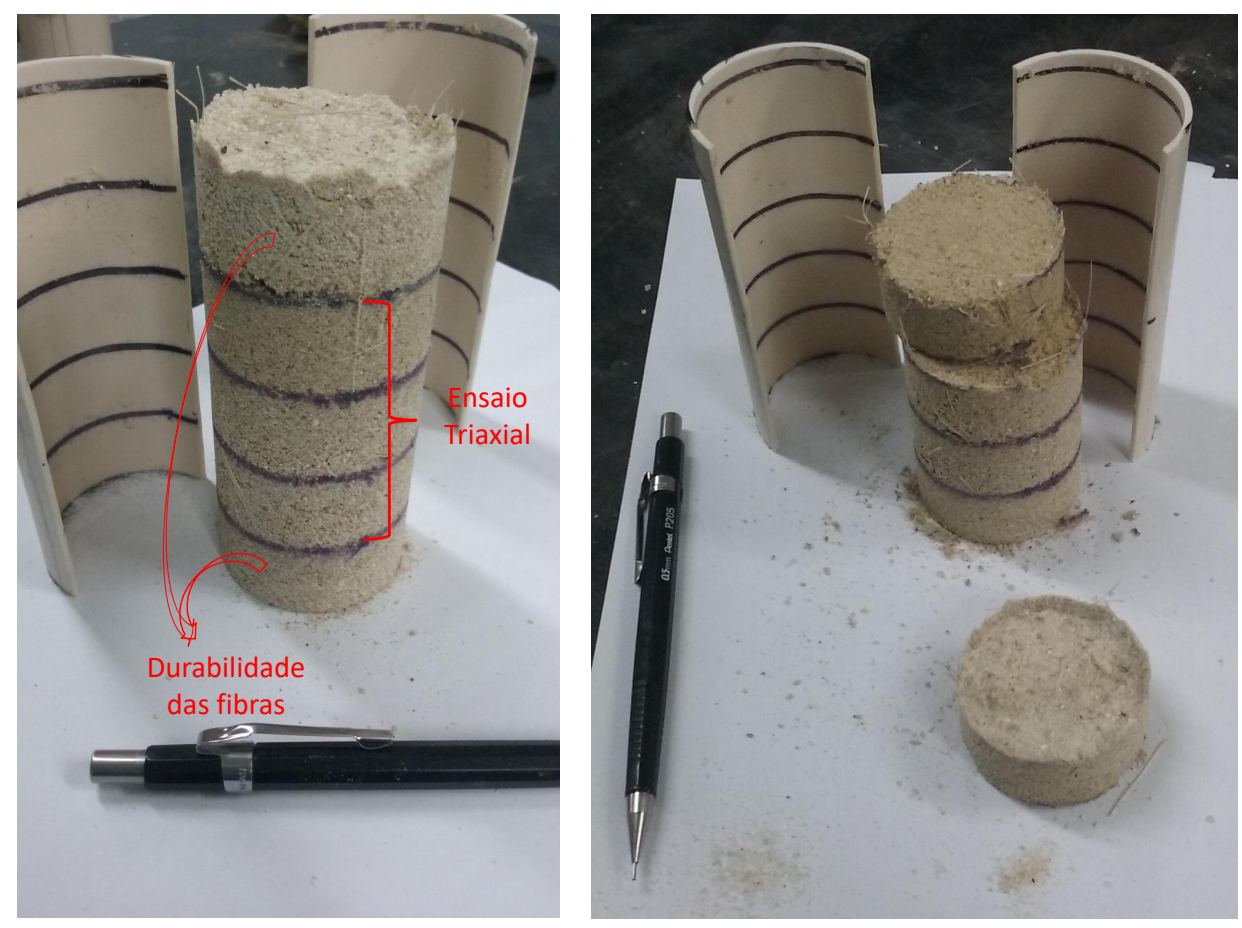

Figura 6.4: Preparo das amostras expostas para as análises de durabilidade

Optou-se, sempre que possível, analisar as fibras presentes na camada de base por esta apresentar, na maioria das vezes, valor de umidade similar ao das camadas centrais dos tubos que eram utilizadas nos ensaios triaxiais.

A camada de base do terceiro tubo retirado do telhado era utilizada para a determinação do pH. O método de preparo da amostra e as condições da análise seguiram o apresentado na Seção 3.1.3.

Imagens de MEV também foram realizadas no compósito areia-curauá sem tratamento exposto por 8 meses. A amostra foi previamente recoberta com ouro para se tornar mais condutora e mais adequada à análise ao MEV. Estas imagens foram obtidas utilizando o microscópio eletrônico de varredura da marca JEOL, modelo JSM-6510LV do Laboratório de Microscopia Eletrônica do Departamento de Engenharia Química dos Materiais (DEQM) da PUC-Rio.

\section{2}
Apresentação e análise dos resultados de caracterização dos reforços expostos

\subsection{1}

\section{Aspecto dos compósitos expostos ao envelhecimento natural}

A Figura 6.5 apresenta compósitos areia-fibra de sisal e curauá sem tratamento expostos aos agentes climáticos e ao tempo. Através de um exame 
visual é possível verificar que as fibras vegetais de sisal e curauá têm uma cor clara inicialmente e que com o passar do tempo, as fibras expostas à matriz arenosa e aos agentes climáticos passaram a apresentar uma coloração mais escura, indicando que elas foram afetadas pelo envelhecimento natural.

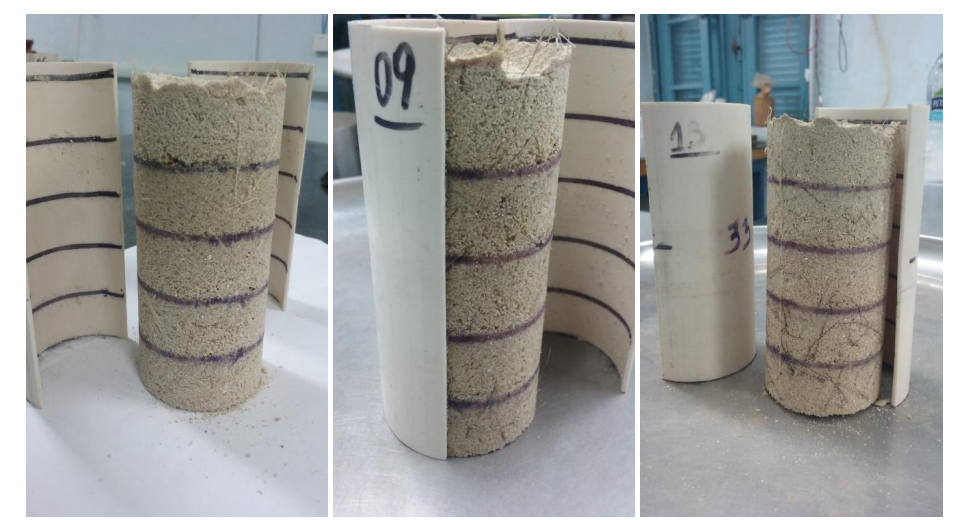

(a)

(b)

(c)

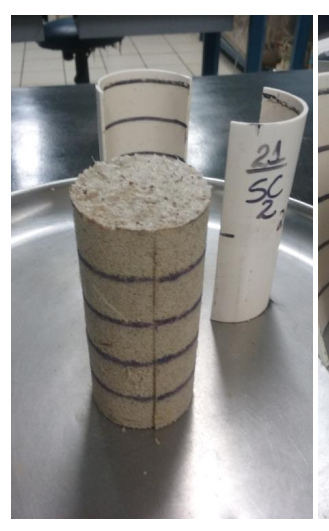

(d)

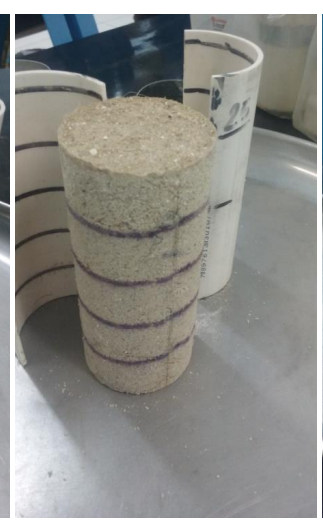

(e)

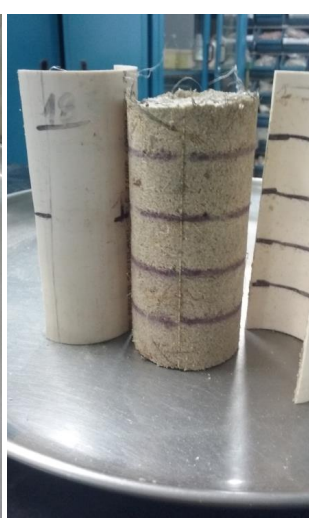

(f)

Figura 6.5: Amostras de solo reforçados com fibras expostos às condições climáticas ao longo do tempo: (a), (b) e (c) sisal 2, 4 e 8 meses, respectivamente e (d), (e) e (f) Curauá 2, 4 e 8 meses, respectivamente.

\section{2 .2}

$\mathrm{pH}$

Os valores de pH em água para todos os compósitos expostos ao envelhecimento natural são apresentados na Figura 6.6.

Analisando os valores de $\mathrm{pH}$ obtidos, observa-se que todos os compósitos analisados e em todos os tempos permanecem com valores abaixo de 7.0, ou seja, permanem ácidos. É consenso na literatura atribuir a degradação das fibras à ataques de microrganismos. Segundo Moreira (2006), os fungos são mais adaptados a valores de $\mathrm{pH}$ menores que 5.0 e bactérias, incluindo actinomicetos (streptomicetos, actinobacterias) e cianobactérias a valores de 
pH entre 6 e 8. Neste sentido a degradação das fibras aconteceria devido ao ataque por parte dos fungos.

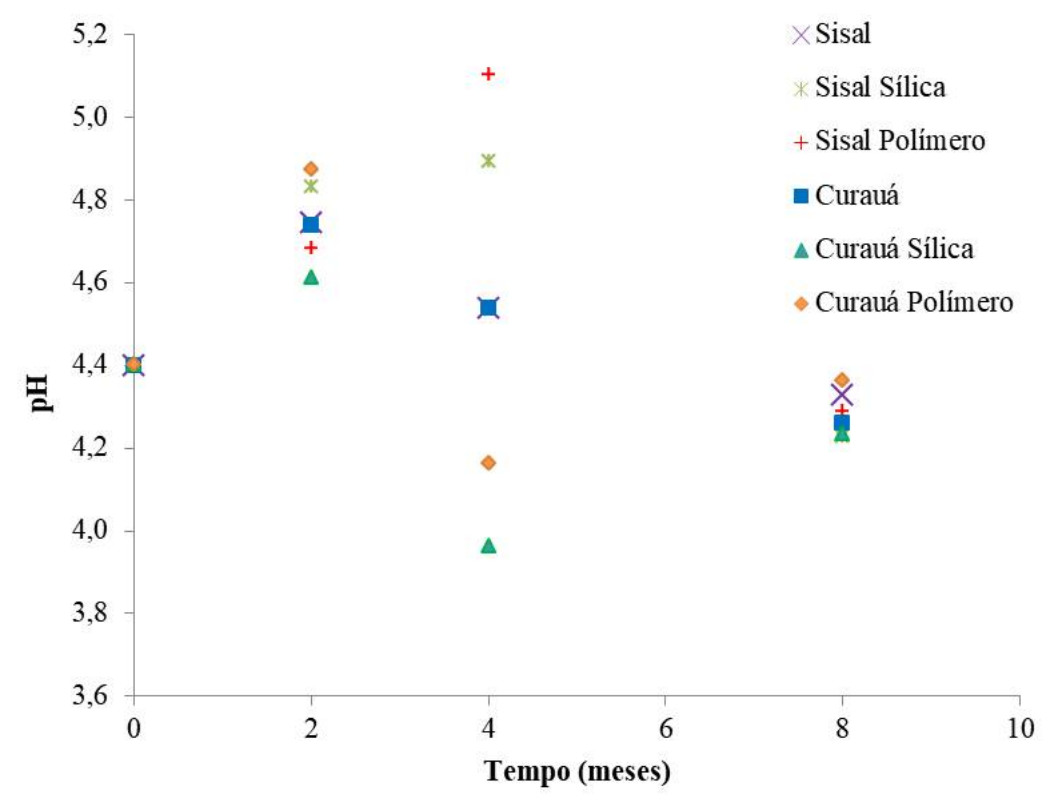

Figura 6.6: pH dos compósitos expostos ao tempo

\subsection{3}

\section{Perda de massa das fibras}

Após cada período de exposição, as fibras localizadas na camada inferior de uma amostra exposta eram retiradas da matriz, lavadas e secas em estufa e então o valor da massa remanescente das fibras era determinado.

Os valores de massa remanescente das fibras para todos os compósitos expostos ao envelhecimento natural são apresentados na Figura 6.7.

Analisando as fibras de sisal e curauá sem tratamento é possível observar que elas perdem massa (perdem dimensões físicas), com o aumento do tempo de exposição, e que as perdas das fibras de curauá foram mais pronunciadas que as de sisal, com uma perda de $50 \%$ após 8 meses de exposição. Este resultado indica que a fibra de curauá apresenta maior susceptibilidade a degradação em ambientes naturais do que as fibras de sisal.

$\mathrm{O}$ ataque por parte de microrganismos presentes no solo é apontado como responsável pelo processo de biodegradação das fibras resultando em uma rápida deterioração. Como apresentado na Seção 2.4, a composição química das fibras, em específico o teor de lignina, é apontada como a primeira variável na determinação das taxas de degradação das fibras. No entanto, ambas as fibras vegetais estudadas apresentam composição química muito semelhante, ou seja, mesmos teores de celulose e de lignina, não justificando a diferença de 
perda das propriedades mecânicas observada nos compósitos reforçados com as duas fibras.

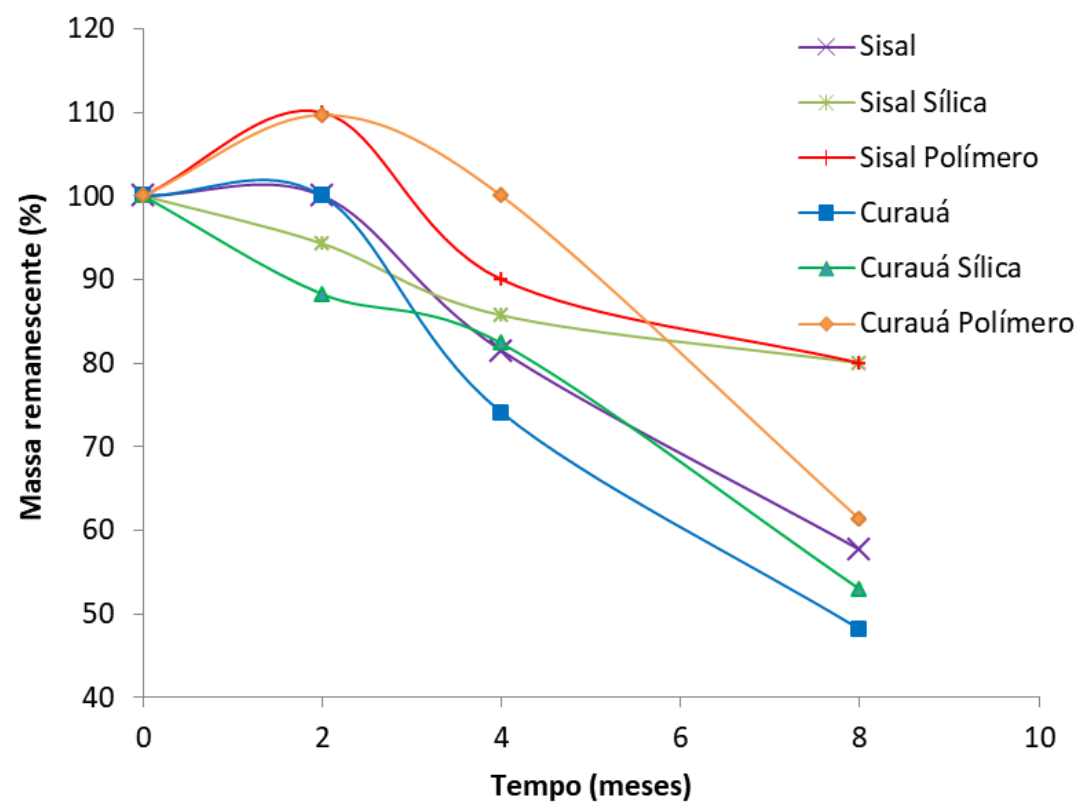

Figura 6.7: Massa remanescente das fibras expostas ao solo, aos agentes climáticos e ao tempo

Neste caso, a maior susceptibilidade a degradação em ambientes naturais das fibras de curauá poderia ser explicada pelo menor diamêtro das fibras, o que aumenta sua superficie específica, proporcionando um maior ataque microbiológico. Assim, a explicação utilizada para justificar o melhor comportamento mecânico da areia reforçada com fibra de curauá no tempo zero (de controle) seria a mesma para justificar sua rápida deterioração.

Um outro ponto seria a maior capacidade de absorção de água da fibra de curauá em relação com a de sisal. Segundo Methacanon et al. (2010) quanto maior a capacidade de absorção de água da fibra, maior é a sua susceptibilidade a este tipo de ataque.

A densidade relativa de $50 \%$ das amostras expostas permite uma maior permeabilidade da água da chuva e consequentemente uma condição de elevada umidade além de manter um alto grau de oxigenação, condições ideais para a proliferação de microrganismos.

Apesar deste método de análise ter expressado consideráveis perdas de massa das fibras, visualmente esta perda foi muito maior, a ponto de após 8 meses de exposição não haver mais fibras de curauá no comprimento de trabalho $(25 \mathrm{~mm})$ para a realização de ensaios de tração (isso na camada de base). A justificativa para os valores de massa remanescentes obtidos é 
que apesar de todo cuidado ter sido tomado, os poucos pedaços de fibras remanescentes, provavelmente fibras que apresentavam maiores áreas de seções transversais inicialmente, continham grãos de areia aderidos.

Após 8 meses de exposição as fibras de sisal foram encontradas em maior quantidade e em dimensões que permitiu a realização de ensaios de tração. No entanto, estas fibras apresentavam uma coloração escura, e estavam bem fragilizadas ao toque dos dedos.

Neste sentido, a degradação das fibras vegetais expostas ao envelhecimento natural não apenas provoca perdas nas propriedades mecânicas das fibras, mas também perdas de massa.

As fibras vegetais tratadas apresentaram valores de massa remanescente maiores que as fibras sem tratamento, indicando que os tratamentos contribuiram para o aumento da durabilidade das mesmas.

As curvas das fibras vegetais tratadas com sílica e polímero apresentaram similaridades. O ganho de massa inicial proporcionado pelo tratamento com polímero em ambas as fibras seria devido à aderência de grãos de areia em sua superfície, que não foi possível tirar com uma simples lavagem. As fibras submetidas a este tratamento resultavam com uma superfície apresentando um efeito de cola.

Esta adesão de grãos de areia nas fibras tratadas com polímero afetou também os valores de massa remanescente após 8 meses de exposição, uma vez que os valores encontrados não condiziam com o que visulamente foi observado. As fibras tratadas com sílica se apresentaram em maior quantidade, mais inteiras e em melhores condições do que as fibras tratadas com polímero, indicando que estas são mais susceptíveis à degradação em ambientes naturais. Supondo a degradação ser por ataques de microrganismos, este resultado corrobora com o tipo de tratamento aplicado, o polímero é orgânico (mais material para ser degradado) enquanto que a sílica inorgânica (forma uma barreira de proteção). Um outro ponto seria a menor capacidade de absorção de água das fibras tratadas com sílica.

O efeito de perda de massa das fibras provocado pela sua exposição ao solo, agentes climáticos e tempo provavelmente será o que regerá qualquer variação observada no comportamento mecânico dos compósitos areia-fibras vegetais expostos ao tempo.

Apenas um esclarecimento, a proposta inicial deste trabalho tinha por base amostras de solo reforçado com fibras expostas em caixas com dimesão $30 \times 30 \times 30 \mathrm{~cm}$ que chegaram a ser confeccionadas e expostas ao tempo. No entanto, após 4 meses de exposição observou-se a perda de massa considerável de massa das fibras, e frente ao tamanho das amostras e da falta de metodologia 
Capítulo 6. Durabilidade das fibras submetidas ao envelhecimento natural 106

para avaliar este fenômeno, optou-se pela realização de amostras menores (tubos bipartidos) que resultaram nos ensaios aqui apresentados.

\subsection{4}

\section{Análise microestrutural}

A Figura 6.8 mostra a microestrutura das fibras de sisal e curauá sem tratamento expostas aos agentes climáticos por 2, 4 e 8 meses.
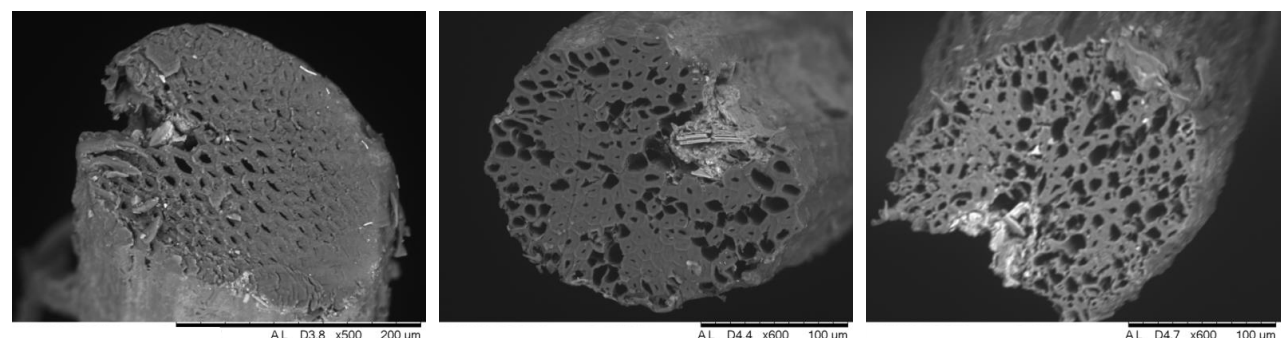

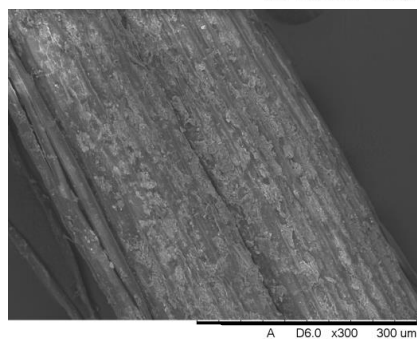

(a)
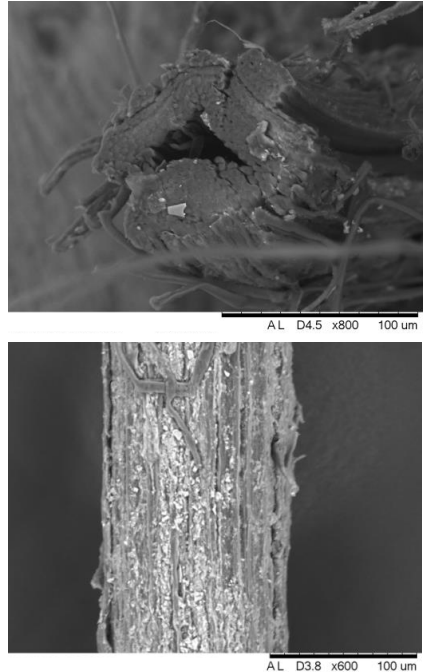

(d)

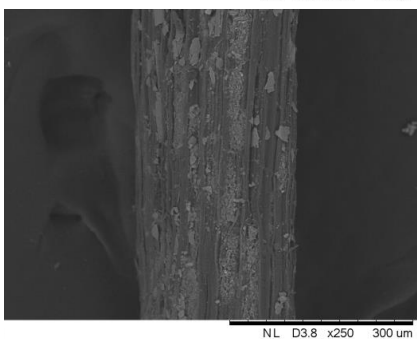

(b)
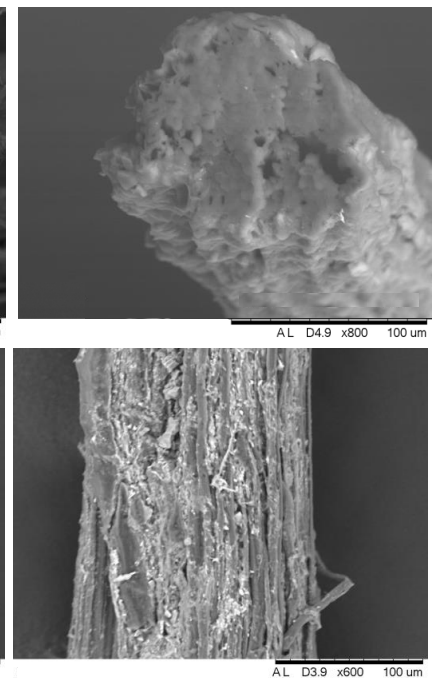

(e)

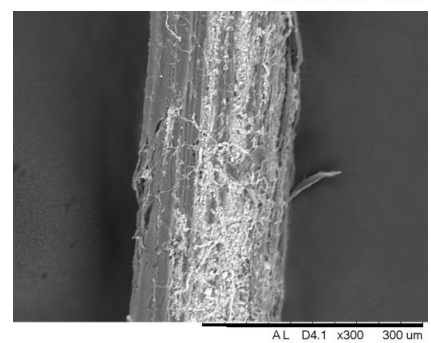

(c)
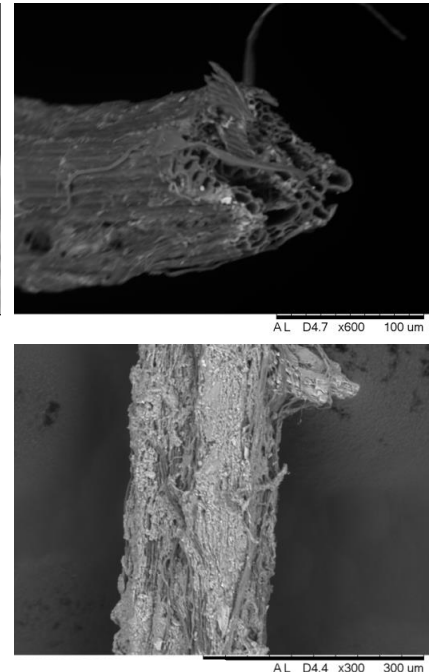

(f)

Figura 6.8: Morfologia da seção transversal e superfície das fibras vegetais sem tratamento ao longo do tempo: (a), (b) e (c) sisal 2, 4 e 8 meses, respectivamente e (d), (e) e (f) curauá 2,4 e 8 meses, respectivamente.

A análise morfológica não registrou alteração nos limites das seções transversais das fibras estudadas, concluindo assim que a área das seções transversais manteve a média de valores obtidos para a fibras nas amostras de controle. Vale ressaltar que as fibras aqui analisadas foram aquelas que, provavelmente 
por apresentarem inicialmente maior área de seção transversal, remanesceram no compósito. Assim, devido a grande variabilidade das dimensões das fibras, conclusões a cerca de alterações na área da seção transversal só poderiam ser tomadas se uma mesma amostra de fibra pudesse ser analisada durante essa passagem do tempo.

Analisando a seção transversal, a morfologia padrão da fibra de sisal, com suas estruturas e lúmens bem definidos tornou possível melhor visualizar os efeitos do envelhecimento natural. O aumento do tempo de exposição aos agentes climáticos provocou uma diminuição progressiva da área efetiva da seção transversal com perdas da parede secundária, mantendo intacta as delimitações entre as fibrocelulas (lamelas médias).

As fibras de curauá também sofreram com a exposição aos agentes climáticos, mas pelo seu tipo de estrutura fica difícil estabelecer os efeitos gerados. No entanto, com 4 meses de exposição é possível observar que algumas fibrocelulas também apresentaram perda da parede celular e essa perda foi muito maior nas fibras com 8 meses.

O fato de ter sido a parede celular secundária a mais afetada pelos efeitos do envelhecimento natural e sabendo que a celulose é o principal componente desta estrutura reforça ser o ataque por parte de fungos e bactérias o principal causador de sua degradação. A perda da parede secundária, estrutura que determina o comportamento mecânico da fibra, sugere possíveis consequências nas propriedades mecânicas da fibra.

Quanto a superfície longitudial externa das fibras, ambas deixaram de exibir uma superfície lisa, com o surgimento de uma estrutura filamentosa, e com as fibras de curauá sendo mais afetadas com o aumento do tempo de exposição.

Essa formação identificada indica que as superfícies foram colonizadas por microrganismos filamentosos como fungos e actinomicetos reforçando a ideia de que a degradação das fibras vegetais reforçando uma matriz arenosa é resultante de um ataque microbiano. Imagens desta estrutura são encontrados em (Alvarez et al., 2006; Barrionuevo, 2004).

A Figura 6.9 mostra a microestrutura das fibras de sisal e curauá tratadas com sílica e polímero expostas aos agentes climáticos por 8 meses. Estas imagens foram obtidas utilizando o MEV da marca JEOL, modelo JSM-6510LV do Laboratório de Microscopia Eletrônica do Departamento de Engenharia Química dos Materiais (DEQM) da PUC-Rio.

Analisando a seção transversal observa-se que a microestrutura permaneceu mais intacta, sem tantas perdas nas paredes secundárias, enquanto que a superfície de ambas as fibras apresentou-se mais afetada, no entanto, esta 
observação feita estaria relacionada a aderência de grãos de solo na superfície das fibras. Reforça-se aqui que, principalmente quanto a fibra de curauá, após 8 meses de exposição, apenas pequenos pedaços de fibras ainda foram encontrados no compósito, a degradação por perda de massa foi visível, e que essas imagens poderiam dar uma falsa impressão de que as fibras mantiveram sua macroestrutura.

(a)
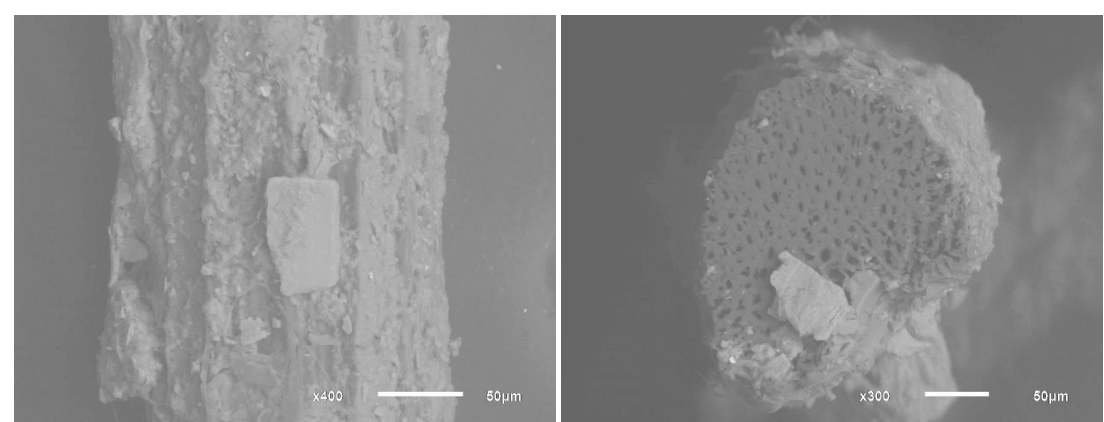

(b)
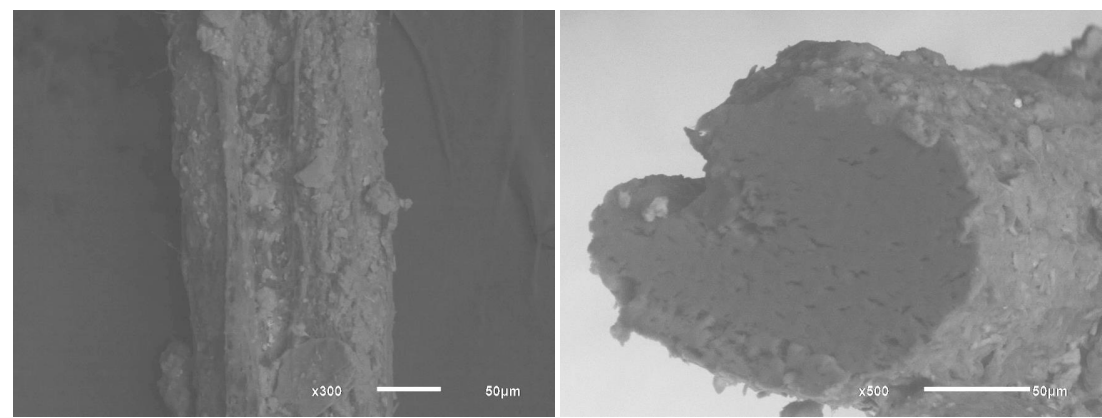

(c)
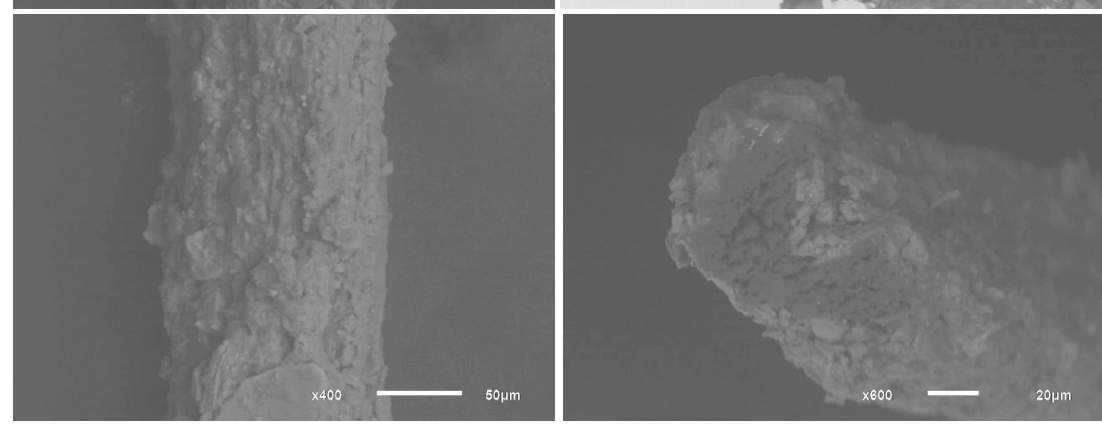

(d)
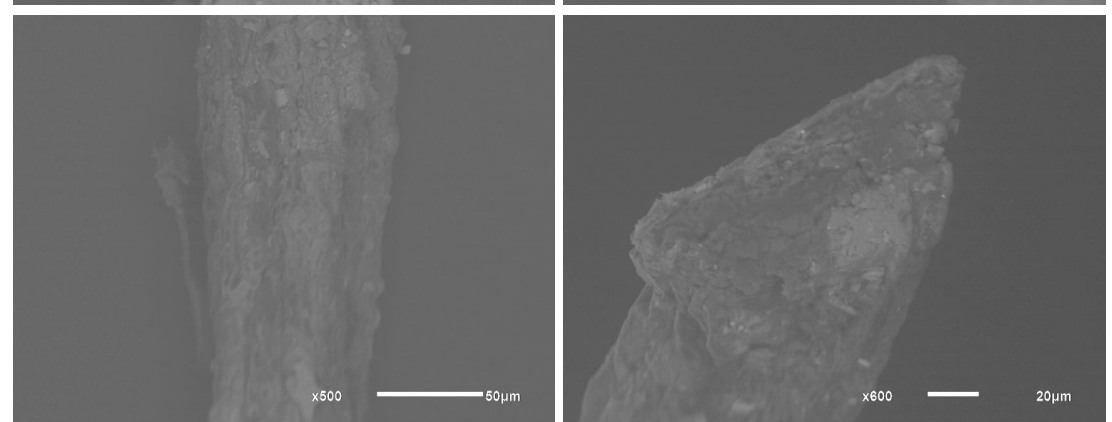

Figura 6.9: Morfologia da seção transversal e superfície das fibras vegetais tratadas após 8 meses de exposição: (a) sisal-sílica, (b)sisal-polímero, (c) curauá-sílica e (d) curauá-polímero 


\section{2 .5}

\section{Espectroscopia no Infravermelho por Transformada de Fourier (FTIR)}

Os espectros de FTIR das fibras vegetais sem tratamento expostas ao solo, agentes climáticos e tempo são mostrados na Figura 6.10. Os espectros permaneceram mostrando as características dos modos de vibração das fibras lignocelulósicas de acordo com a literatura (Ferreira, 2016), mesmo após 8 meses de exposição.

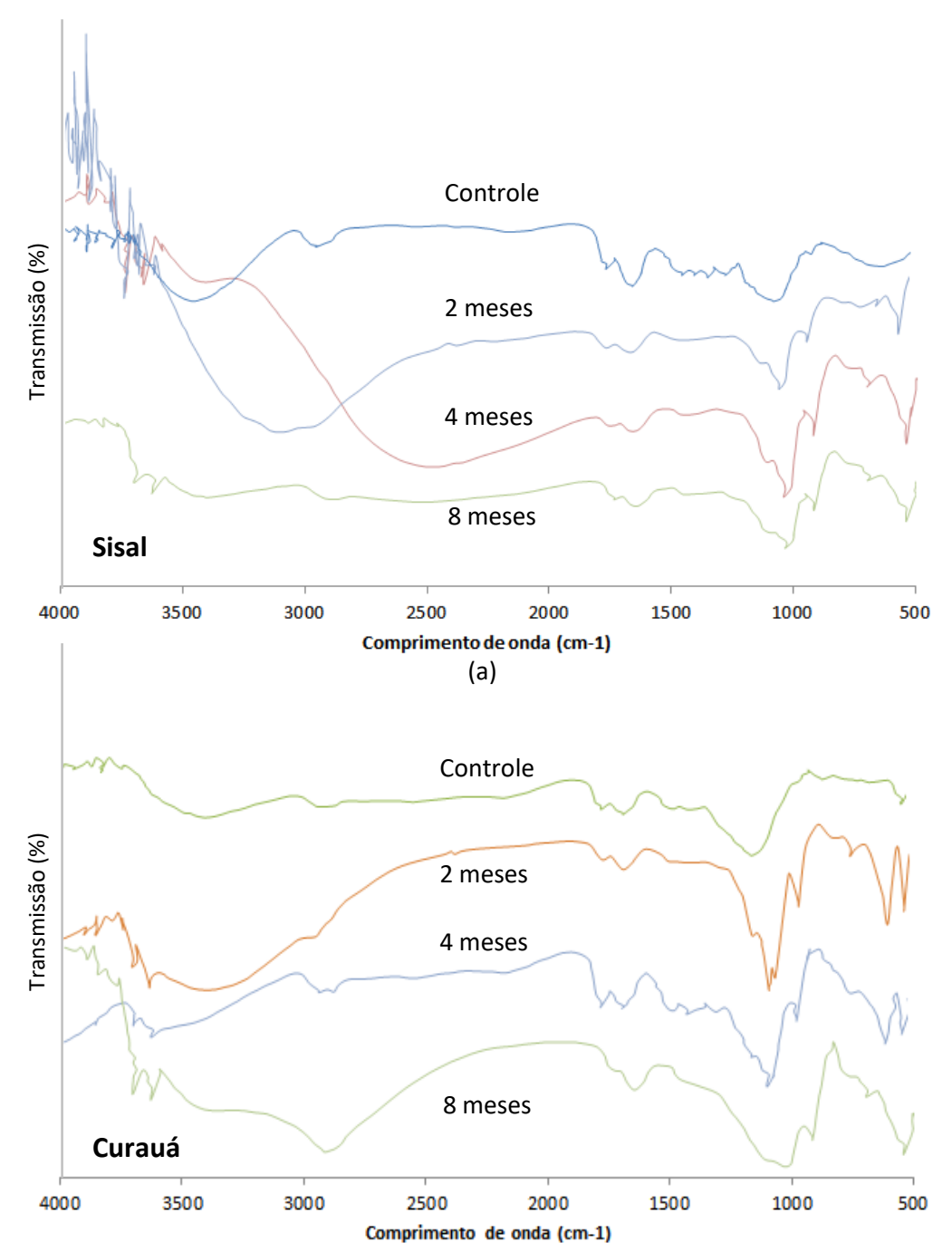

(b)

Figura 6.10: Espectros FTIR das fibras vegetais sem tratamento expostas ao envelhecimento natural

A principal mudança observada foi nos picos localizados entre 3221 e $3500 \mathrm{~cm}^{-1}$, atribuído a várias faixas de alongamento de $\mathrm{OH}$ e a ligações de hidrogênio, estando relacionada a presença de água. Os picos característicos localizados entre 1700 e $700 \mathrm{~cm}^{-1}$ não foram afetados. $\mathrm{O}$ pico em $500 \mathrm{~cm}^{-1}$ pode ser associado aos grãos de areia aderidos às fibras. 
É complexo correlacionar esta informação com o que foi observado visualmente, pois apesar dos espectros mostrarem as características dos modos de vibração das fibras lignocelulósicas não significa que as fibra estejam intactas, já que a degradação física (perda de massa/dimensões) foi observada visualmente.

\subsection{6}

\section{Espectrometria de Fluorescência de Raios-X (FRX)}

A composição química das fibras vegetais de sisal e curauá sem tratamento após 8 meses de exposição é apresentada na Tabela 6.1.

Tabela 6.1: Composição química das fibras vegetais sem tratamento após 8 meses de exposição

\begin{tabular}{ccccccccc}
\hline & \multicolumn{7}{c}{ Constituintes em porcentagens } \\
\cline { 2 - 9 } Amostra & $\mathrm{CH}$ & $\mathrm{Al}_{2} \mathrm{O}_{3}$ & $\mathrm{CaO}$ & $\mathrm{SO}_{3}$ & $\mathrm{~K}_{2} \mathrm{O}$ & $\mathrm{Fe}_{2} \mathrm{O}_{3}$ & $\mathrm{SiO}_{2}$ & outros \\
\hline Sisal & 24.80 & 41.56 & 0.55 & 0.20 & 1.11 & 0.96 & 30.26 & 0.57 \\
Curauá & 18.12 & 41.44 & 0.21 & 0.00 & 2.31 & 1.00 & 36.28 & 0.65 \\
\hline
\end{tabular}

Analisando os valores obtidos e comparando com os apresentados nas Tabela 4.3 relativos aos das fibras de controle observa-se que $\mathrm{CH}$ deixa de ser o elemento principal da amostra, no entanto não significa necessariamente que as fibras perderam este constituinte mas que os materiais (grãos do solo$\mathrm{SiO}_{2}$ e $\mathrm{Al}_{2} \mathrm{O}_{3}$ ) que permaneceram aderidos em sua superfície após a lavagem e secagem das fibras expostas passaram a ser predominantes.

Interessante notar que, mesmo sendo a areia predominantemente $\mathrm{SiO}_{2}$, o que mais predominou aderido a superfície das fibras foi $\mathrm{Al}_{2} \mathrm{O}_{3}$. Isto ocorreu porque o $\mathrm{Al}_{2} \mathrm{O}_{3}$ é mais presente na fração mais fina do solo arenoso usado como matriz do compósito, que é a fração que mais ficou aderida às fibras.

\subsection{7}

\section{Ensaio de tração direta}

Após cada período de exposição, as fibras localizadas na camada inferior de uma amostra exposta eram retiradas da matriz, lavadas e secas em estufa e então preparadas para serem submetidas ao ensaios de tração direta.

Visualmente foi possível identificar que o envelhecimento natural atuou sobre as fibras vegetais afetando seu comprimento e consequentemente na perda de massa do reforço no compósito. A fibra de curauá exposta por 8 meses foi afetada a tal ponto que impossibilitou a realização de ensaios de tração nas fibras que ficaram na base da amostra. Para este tempo as fibras de curauá na camada do topo da amostra foram usadas em substituição. 
Para todos os outros tempos e para a fibra de sisal, o envelhecimento natural tornou as fibras expostas mais frágeis ao manuseio, ou seja, mesmo apresentando fibras em quantidade suficiente e com as dimensões necessárias para os ensaio de tração, elas se rompiam facilmente ao toque. Muitas das fibras de sisal expostas por 8 meses preparadas para o ensaio de tração rompiam ou no momento do posicionamento nas garras ou na própria pressão exercida pelas garras.

A exposição ao solo, aos agentes climáticos diversos e ao tempo provoca perda de resistência à tração das fibras, assim, para avaliar a durabilidade das mesmas foi realizado ensaios de tração direta após etapas de envelhecimento natural (2, 4 e 8 meses).

A Tabela 6.2 apresenta os resultados dos ensaios de tração direta para as duas fibras vegetais estudadas sem tratamento expostas por 2, 4 e 8 meses e a Figura 6.11 apresenta as curvas tensão vs deformação dos ensaios e uma reta com a média calculada.

Tabela 6.2: Resultados médios e desvios-padrões dos ensaios de tração nas fibras vegetais sem tratamento superficial expostas ao envelhecimento natural

\begin{tabular}{|c|c|c|c|c|c|}
\hline Fibra & $\begin{array}{l}\text { Tempo de } \\
\text { exposição } \\
\text { (meses) }\end{array}$ & $\begin{array}{c}\text { Resistência } \\
\text { à tração } \\
(\mathrm{MPa})\end{array}$ & $\begin{array}{l}\text { Módulo de } \\
\text { elasticidade } \\
\quad(\mathrm{GPa})\end{array}$ & $\begin{array}{c}\text { Capacidade de } \\
\text { deformação } \\
(\%)\end{array}$ & $\begin{array}{c}\text { Área } \\
\text { adotada } \\
\left(\mathrm{mm}^{2}\right)\end{array}$ \\
\hline \multirow{3}{*}{ Sisal } & 2 & $\begin{array}{c}58.55 \\
(31.83)\end{array}$ & $\begin{array}{c}4.74 \\
(1.69)\end{array}$ & $\begin{array}{c}1.37 \\
(0.74)\end{array}$ & \multirow{3}{*}{0.023} \\
\hline & 4 & $\begin{array}{c}55.27 \\
(38.42)\end{array}$ & $\begin{array}{c}4.33 \\
(1.78)\end{array}$ & $\begin{array}{c}1.43 \\
(0.52)\end{array}$ & \\
\hline & 8 & $\begin{array}{c}38.45 \\
(17.41)\end{array}$ & $\begin{array}{c}2.82 \\
(1.16)\end{array}$ & $\begin{array}{c}1.93 \\
(0.70)\end{array}$ & \\
\hline \multirow{3}{*}{ Curaua } & 2 & $\begin{array}{c}261.36 \\
(117.05)\end{array}$ & $\begin{array}{l}10.94 \\
(2.01)\end{array}$ & $\begin{array}{c}2.61 \\
(0.86)\end{array}$ & \multirow{3}{*}{0.004} \\
\hline & 4 & $\begin{array}{c}90.81 \\
(68.26)\end{array}$ & $\begin{array}{c}4.59 \\
(2.40)\end{array}$ & $\begin{array}{c}1.97 \\
(0.99)\end{array}$ & \\
\hline & $8^{*}$ & $\begin{array}{c}97.34 \\
(59.57)\end{array}$ & $\begin{array}{c}7.14 \\
(2.85)\end{array}$ & $\begin{array}{c}1.56 \\
(0.54)\end{array}$ & \\
\hline
\end{tabular}

* Fibras localizadas na camada superior

Visando melhorar a visualização dos efeitos do envelhecimento natural sobre a máxima tensão de tração das fibras vegetais foi elaborada a Figura 6.12, nela são apresentados também os valores de capacidade de deformação.

Observa-se que o envelhecimento natural afeta consideravelmente o comportamento mecânico das fibra vegetais de sisal e curauá logo nos primeiros 2 meses de exposição. As perdas ocorreram na resistênciaà tração, no módulo de elasticidade e na capacidade de deformação. 


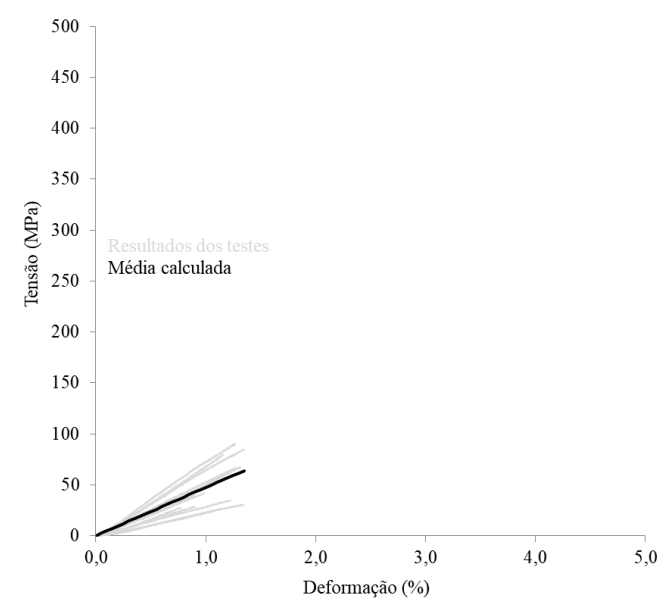

(a)

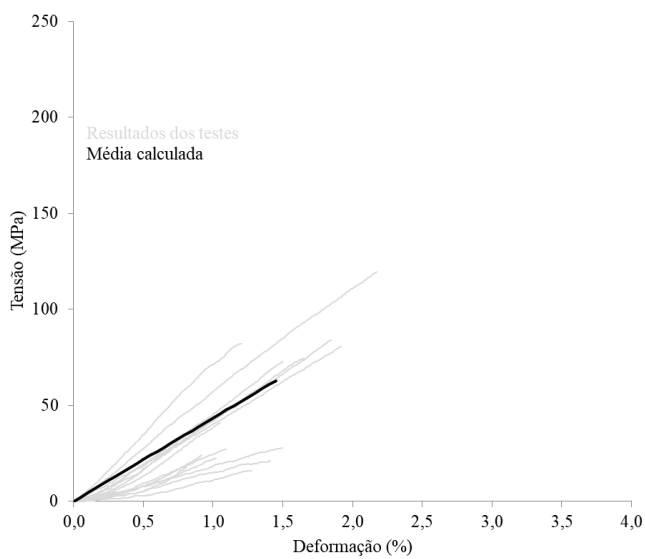

(b)

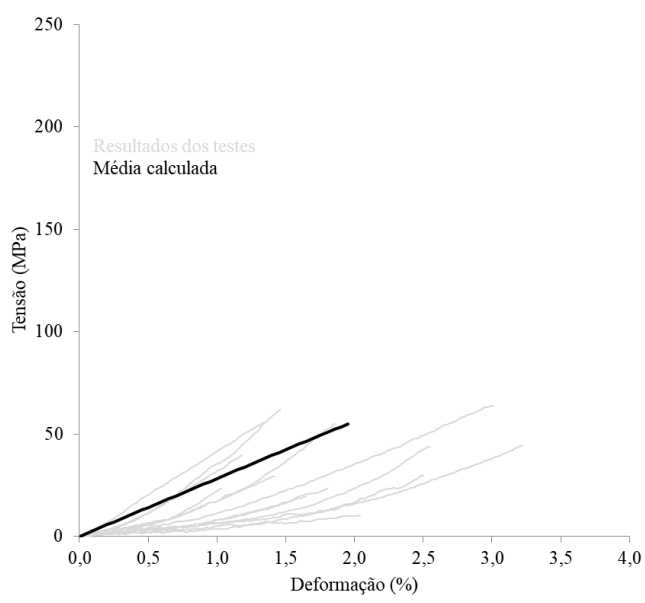

(c)

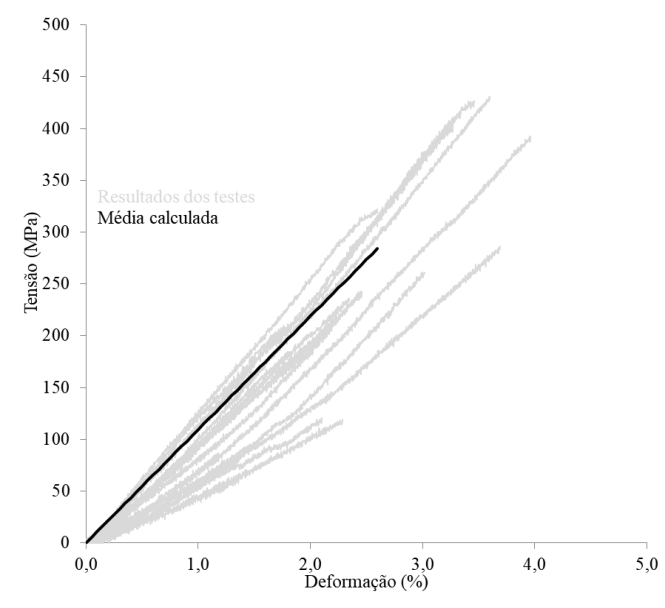

(d)

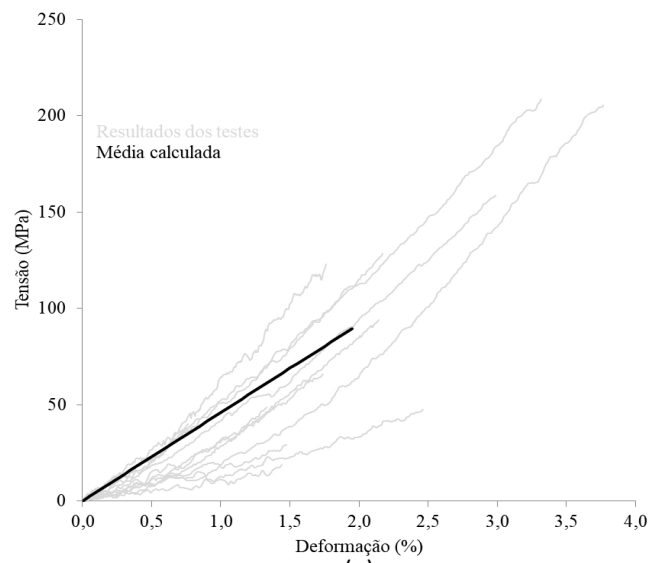

(e)

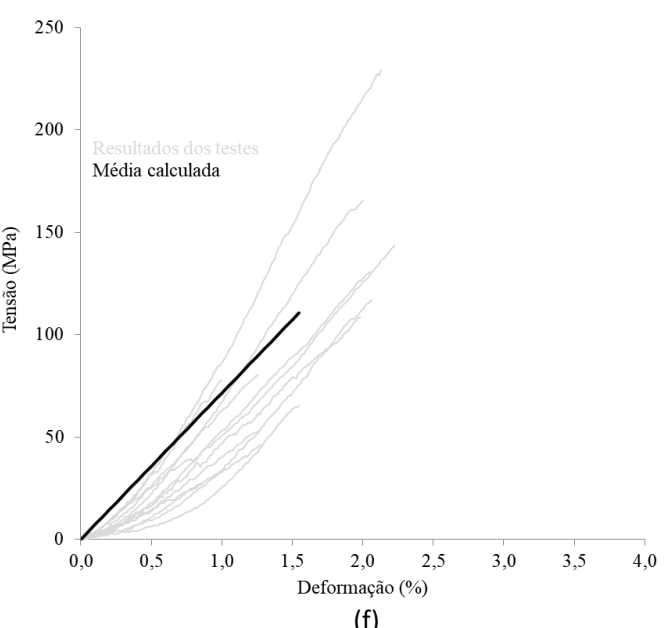

Figura 6.11: Representação gráfica dos resultados e média calculada das fibras vegetais após exposicao ao clima: (a), (b) e (c) sisal nos tempos 2, 4 e 8 meses, respectivamente e (d), (e) e (f) curauá nos tempos 2, 4 e 8 meses, respectivamente 


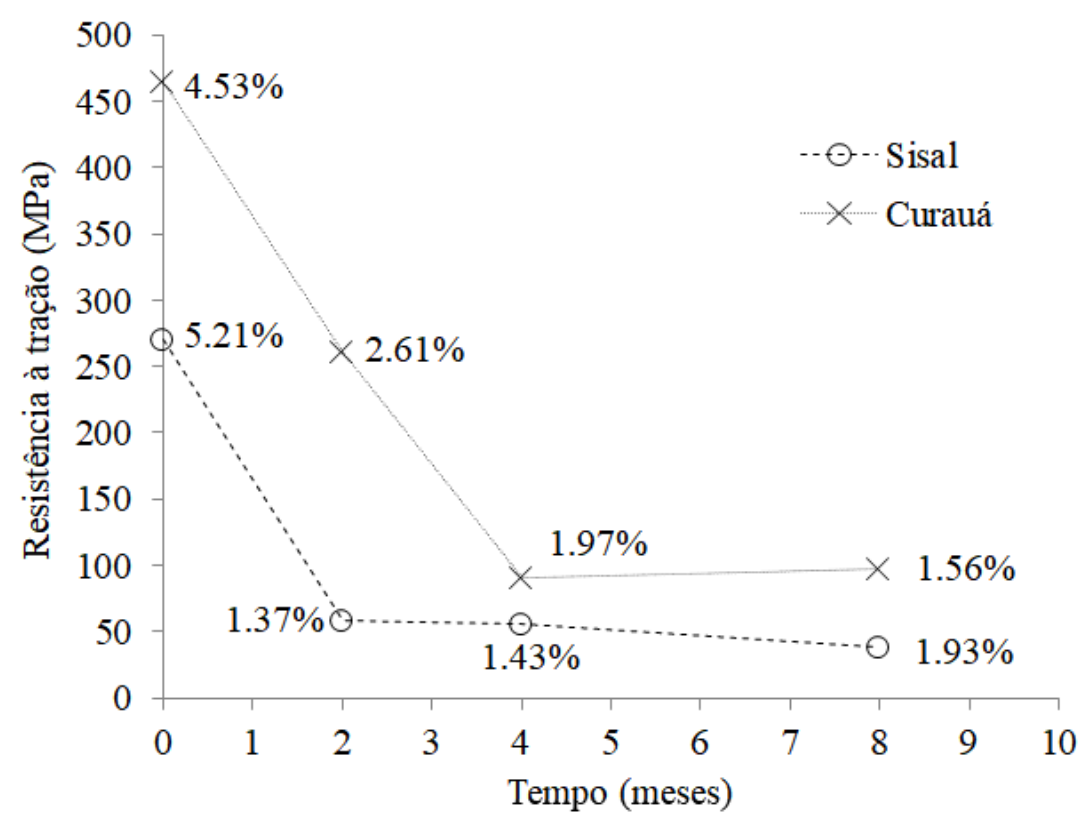

Figura 6.12: Resistência à tração e capacidade de deformação das fibras vegetais sem tratamento expostas ao tempo

As duas fibras avaliadas perderam $80 \%$ da resistência à tração após 8 meses de exposição, sendo que a fibra de sisal perde todo esse valor após 2 meses de exposição enquanto que a fibra de curauá tem esta mesma perda após 4 meses de exposição.

Essa constatação está de acordo com relatos na literatura. Carvalho et al. (2015) e Costa (2013) concluíram que as fibras vegetais expostas às condições ambientais são severamente agredidas ocorrendo rápida e acentuada degradação das propriedades mecânicas durante as primeiras semanas de exposição no solo e que após essa perda inicial verificou-se uma estabilização da resistência, mantendo-se quase inalterável.

\subsection{8}

\section{Micrografias de varredura em compósito exposto ao tempo}

A Figura 6.13 apresenta imagens de MEV realizadas no compósito areiacurauá sem tratamento exposto por 8 meses. Durante a análise foi dada especial atenção às fibras encontradas no compósito e ao contato entre elas e os grãos a sua volta. Estas formações fibra-grão encontradas reforçam a ideia da presença de microrganismos, e cogitasse que sejam biofilmes.

Segundo Costerton et al. (1995), biofilme é uma comunidade complexa e estruturada de microrganismos envoltos por uma matriz extracelular de polissacarídeos aderidos entre si a uma superfície ou interface. 

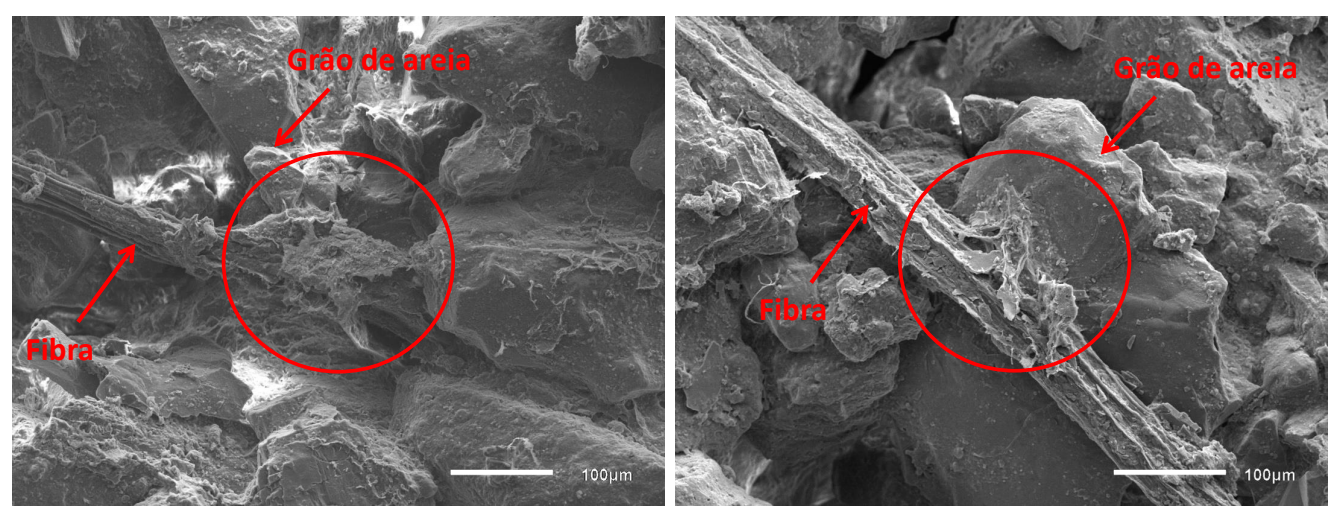

Figura 6.13: Imagens de varredura eletrônica realizadas no compósito areiacurauá exposto por 8 meses

Esse microrganismos tendem a crescer embebidos em uma matriz polimérica de materiais polissacarídeos produzidas por eles mesmos e funcionando como um material de suporte e adesão além de protegê-los contra os efeitos da dessecação, iluminação excessiva, danos mecãnicos e efeitos erosivos (Barrionuevo, 2004).

A identificação destas estruturas levanta a hipótese de que sua presença poderia vir a afetar o comportamento mecânico dos compósitos areia-fibras vegetais 


\section{7 \\ Durabilidade dos compósitos submetidos ao envelhecimento natural}

Neste capítulo são apresentados os resultados e análises dos ensaios triaxiais convencionais realizados em amostras de compósitos solo arenoso fibras vegetais aleatoriamente distribuídas submetidas à exposição de agentes climáticos diversos por 8 meses.

Os elementos de reforço empregados são: fibras de sisal e curauá, com e sem tratamento de impermeabilização superficial com sílica e polímero. O principal objetivo foi investigar e identificar os efeitos dos agentes do envelhecimento natural sobre o comportamento mecânico dos compósitos, bem como avaliar a atuação dos tratamentos superficiais empregados na durabilidade destes compósitos.

Como a degradação das fibras poderá afetar os parâmetros de resistência do compósito, a avaliação da durabilidade do compósito foi realizada por meio de ensaios de compressão triaxial após cada etapa de envelhecimento natural, empregando a prensa triaxial disponível no Laboratório de Geotecnia e Meio Ambiente da PUC-Rio, que foi apresentada na Seção 3.1.5.1. Com os resultados dos ensaios triaxiais foi possível traçar curvas que apresentassem a taxa com a qual os parâmetros de resistência declinam com o tempo.

\section{1}

\section{Materiais e métodos}

\subsection{1}

Moldagem das amostras de compósito expostas as condições ambientais ao longo do tempo para o ensaio triaxial

Como explicado na Seção 6, após cada período de exposição, três tubos eram retirados do ambiente de exposição e o compósito localizado nas três camadas centrais de cada tubo era então separado e preparado para ser submetido ao ensaio triaxial convencional nas mesmas condições que foram submetidas as amostras de controle. Este preparo consistia na correção da umidade $(\mathrm{w}=10 \%)$, homogeneização de cada camada do compósito e compactação diretamente sobre o pedestal da prensa triaxial da mesma maneira que as amostras sem reforço e reforçadas no tempo zero foram realizadas. 
O fato de ter sido adotada a densidade relativa de $50 \%$ em todas as etapas de confecção das amostras permitiu a realização da homogeneização e recompactação sem que ocorresse quebra nas fibras expostas ao envelhecimento.

\section{2}

\section{Apresentação e avaliação dos resultados}

\subsection{1}

\section{Compósitos expostos sem o tratamento das fibras}

Neste item são apresentados e analisados os resultados de dezoito ensaios triaxiais convencionais, com tensões confinantes de 50,100 e $150 \mathrm{kPa}$, realizados em compósitos de areia reforçada com fibras vegetais sem tratamento e aleatoriamente distribuidas na matriz expostos aos agentes climáticos por 8 meses. Buscou-se investigar e identificar o efeito do evelhecimento natural nas propriedades mecânicas deste compósito.

As Figuras 7.1 e 7.2 apresentam em conjunto quatro gráficos obtidos para a série de ensaios triaxiais nos compósitos com as fibras de sisal e curauá, respectivamente, sem tratamento expostos aos agentes climáticos e ao tempo: q vs $\varepsilon_{a}$, p' vs q, $\varepsilon_{v}$ vs $\varepsilon_{a}$, e e vs p'. Os valores de índice de vazios após adensamento e ao final do ensaio além da umidade final, são apresentados na Tabela 7.1.

Analisando as curvas q vs $\varepsilon_{a}$ é possível observar que o envelhecimento natural afetou o mecanismo de ruptura dos compósitos areia-fibra de sisal e curauá sem tratamento expostos aos agentes climáticos. O comportamento de endurecimento adquirido com a adição das fibras nas amostras de controle foi gradualmente sendo perdido com o aumento do tempo de exposição o que, consequentemente, afeta a capacidade de absorção de energia destes materiais.

Também é possível observar que, em ambas as fibras estudadas, a perda do comportamento de endurecimento foi mais pronunciada na maior tensão confinante aplicada $(150 \mathrm{kPa})$. Esta constatação indica a fragilidade das fibras a própria densificação da amostra na etapa de adensamento do ensaio triaxial convecional, e esta de acordo com o observado visualmente (i.e. fibras frágeis ao toque). Quanto maior é a tensão confinante, maior é a interação/atrito entre os grãos de areia e as fibras na etapa de adensamento, o que poderia resultar em uma maior quebra por parte das fibras.

Comparando os resultados obtidos para os compósitos reforçados com as duas fibras estudadas verifica-se que a perda do comportamento de endurecimento foi mais acentuada no compósito reforçado com fibras de curauá, sendo registrado uma grande perda logo no primeiro tempo analisado (2 meses). Tal observação indica que a fibra de curauá é mais susceptivel à degradação em 
ambientes naturais do que a fibra de sisal, e condiz com o observado quanto a perda de massa ter sido mais acentuada com curauá, na Seção 6.2.3 é apresentado possíveis explicações para isso.
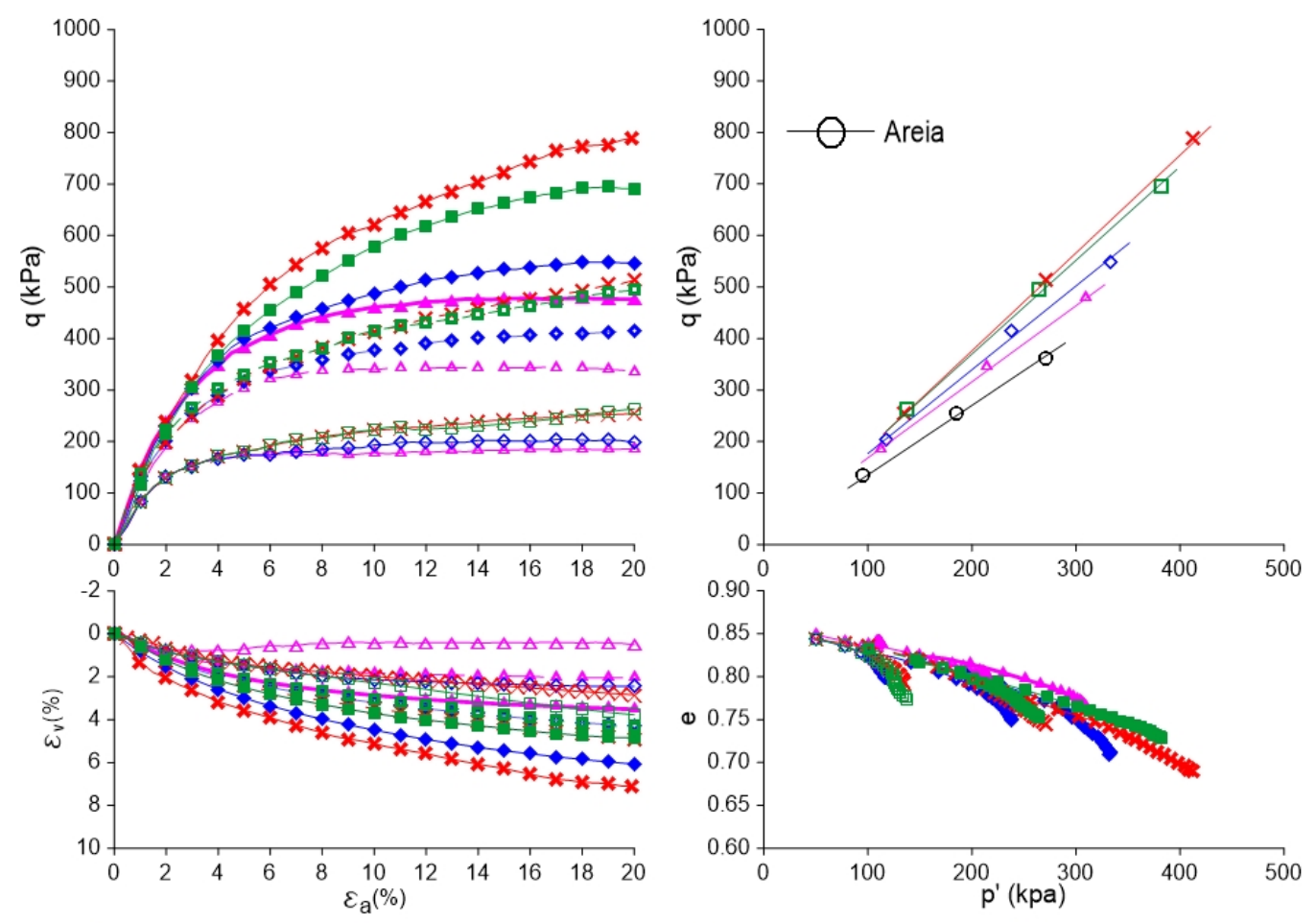

$X$ Areia Sisal $50 \mathrm{kPa} \quad \square$ Areia Sisal $2 \mathrm{~m} 50 \mathrm{kPa} \quad \diamond$ Areia Sisal $4 \mathrm{~m} 50 \mathrm{kPa} \quad \triangle$ Areia Sisal $8 \mathrm{~m} 50 \mathrm{kPa}$

-X-Areia Sisal 100kPa - - A - Areia Sisal $2 \mathrm{~m} \mathrm{100kPa} \diamond$ Areia Sisal $4 \mathrm{~m} 100 \mathrm{kPa} \triangle \triangle$ Areia Sisal $8 \mathrm{~m} 100 \mathrm{kPa}$

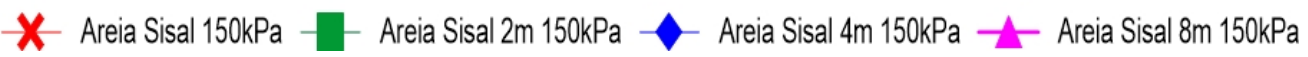

Figura 7.1: Resultado dos ensaios triaxiais convencionais nos compósitos areiasisal sem tratamento expostos ao intemperismo e ao tempo

Apesar de ser registrado alterações no comportamento mecânico dos compósitos reforçados com fibras de sisal e curauá ocasionados pela exposição destes aos agentes climáticos (envelhecimento natural) por oito meses, as fibras vegetais continuaram contribuindo como reforço mantendo a resistência do compósito acima das amostras sem reforço (areia) até o limite de deformação axial medido de $20 \%$ (Figura 3.6).

Nas curvas $\varepsilon_{v}$ vs $\varepsilon_{a}$, nota-se uma tendência de redução de volume para quase todas as amostras em todas as tensões de confinamento empregadas, sendo que esse comportamento de redução foi diminuindo a medida que o tempo de exposição foi aumentando.

Interessante notar que apesar do comportamento tensão-deformação do compósito estar se aproximando do comportamento da areia sem reforço com o aumento do tempo de exposição, o comportamento da variação volumétrica está se distanciando cada vez mais. O envelhecimento natural está afetando 
a estrutura do compósito reforçado e dificultando a deformação da matriz arenosa, fato também registrado pelas curvas de e vs p'.
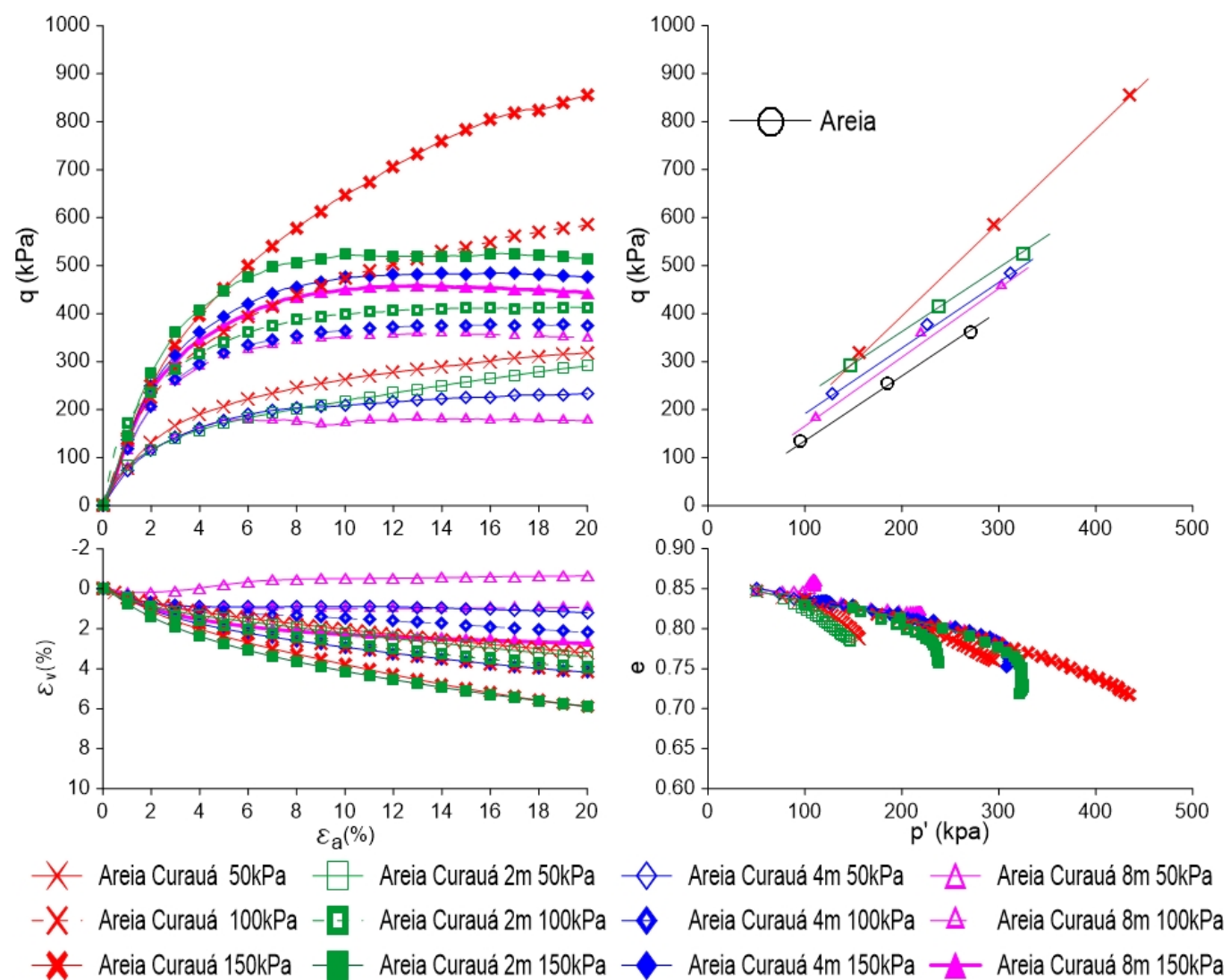

Figura 7.2: Resultado dos ensaios triaxiais convencionais nos compósitos areiacurauá sem tratamento expostos ao intemperismo e ao tempo

Essa mudança observada no comportamento tensão-deformação estaria de acordo com as perdas de massa significativas das fibras vegetais, conforme apresentado na Seção 6.2.3, já que supõem-se que as fibras estariam se decompondo/desfazendo com o decorrer do tempo de envelhecimento permanecendo somente areia na amostra.

A mudança de comportamento observada nas curvas $\varepsilon_{v}$ vs $\varepsilon_{a}$ e e vs p' poderia ser resultado da presença de biofilme observado em algumas imagens do MEV, conforme relatado na Seção 6.2.8.

A Tabela 7.2 apresenta os valores obtidos para tensão desviadora e deformação axial de ruptura, o aumento de resistência de pico proporcionado pela presença das fibras sem tratamento com relação a amostra arenosa, a capacidade de absorção de energia $\left(E_{\text {def }}\right)$ e os parâmetros de resistência ao cisalhamento (c' e $\left.\phi^{\prime}\right)$ obtidos.

A Tabela 7.2 quantifica e reforça as observações feitas nas Figuras 7.1 e 7.2. As fibras vegetais continuam contribuindo como elementos de reforço da matriz arenosa mesmo após 8 meses de envelhecimento natural, e que mesmo 
após esse tempo, a máxima tensão desviadora dos compósitos permanece, aproximadamente, $33 \%$ superior que a da amostra arenosa.

Tabela 7.1: Índices físicos após o adensamento e no final do ensaio, dos corpos de prova de compósitos areia-sisal sem tratamento expostos ao intemperismo e ao tempo

\begin{tabular}{|c|c|c|c|c|c|}
\hline \multirow{2}{*}{ Amostra } & \multirow{2}{*}{$\begin{array}{c}\text { Tempo de } \\
\text { exposição } \\
\text { (meses) }\end{array}$} & \multirow{2}{*}{$\sigma_{3}^{\prime}$} & $\begin{array}{c}\text { Após o } \\
\text { adensamento }\end{array}$ & \multicolumn{2}{|c|}{$\begin{array}{c}\text { Após o } \\
\text { cisalhamento }\end{array}$} \\
\hline & & & $e_{\text {adens }}$ & $e_{\text {final }}$ & $\begin{array}{c}w_{\text {final }} \\
(\%)\end{array}$ \\
\hline \multirow{9}{*}{ Areia-sisal } & \multirow{3}{*}{2} & 50 & 0.844 & 0.774 & 27.003 \\
\hline & & 100 & 0.832 & 0.753 & 26.165 \\
\hline & & 150 & 0.816 & 0.728 & 25.088 \\
\hline & \multirow{3}{*}{4} & 50 & 0.843 & 0.798 & 26.628 \\
\hline & & 100 & 0.827 & 0.749 & 25.536 \\
\hline & & 150 & 0.819 & 0.709 & 24.917 \\
\hline & \multirow{3}{*}{8} & 50 & 0.849 & 0.840 & 26.501 \\
\hline & & 100 & 0.837 & 0.799 & 26.131 \\
\hline & & 150 & 0.824 & 0.760 & 25.109 \\
\hline \multirow{9}{*}{ Areia-curauá } & \multirow{3}{*}{2} & 50 & 0.848 & 0.785 & 25.394 \\
\hline & & 100 & 0.829 & 0.757 & 25.749 \\
\hline & & 150 & 0.826 & 0.719 & 25.527 \\
\hline & \multirow{3}{*}{4} & 50 & 0.851 & 0.829 & 26.918 \\
\hline & & 100 & 0.835 & 0.795 & 26.212 \\
\hline & & 150 & 0.829 & 0.753 & 24.664 \\
\hline & \multirow{3}{*}{8} & 50 & 0.849 & 0.861 & 26.914 \\
\hline & & 100 & 0.838 & 0.821 & 26.530 \\
\hline & & 150 & 0.825 & 0.775 & 26.054 \\
\hline
\end{tabular}

Comparando esses resultados com os valores apresentados na Tabela 5.2 constata-se que mesmo tendo a fibra de curauá contribuido mais significamente no aumento da resistência da matriz arenosa (amostra de controle), após o período de exposição sua contribuição passa a ser semelhante a do compósito de fibra de sisal também exposto. Reforça novamente a maior susceptibilidade à degradação em ambientes naturais da fibra de curauá e que a justificativa usada para explicar o porque desta maior contribuição inicial (a fibra de curauá tem maior fator de forma do que a fibra de sisal), é também usada para justificar sua maior susceptibilidade à degradação.

Observa-se também que o envelhecimento natural afeta consideravelmente o compósito reforçado com fibra de curauá logo nos primeiros 2 meses de exposição com perdas relevantes nos valores de máxima tensão desviadora e capacidade de absorção de energia de deformação, enquanto que tais magnitudes de perdas só foram registradas após 4 meses de exposição no compósito 
com fibra de sisal.

Tabela 7.2: Valores das propriedades mecânicas e dos parâmetros de resistência para os compósitos areia-fibras vegetais sem tratamento expostos ao intemperismo

\begin{tabular}{|c|c|c|c|c|c|c|c|c|}
\hline Amostra & $\begin{array}{c}\text { Tempo de } \\
\text { exposição } \\
\text { (meses) }\end{array}$ & $\begin{array}{c}\sigma_{3}^{\prime} \\
(\mathrm{kPa})\end{array}$ & $\begin{array}{c}\text { Tensão } \\
\text { desviadora } \\
\text { de ruptura } \\
(\mathrm{kPa})\end{array}$ & $\begin{array}{c}\text { Deformação } \\
\text { axial } \\
(\%)\end{array}$ & $\begin{array}{c}\text { Acréscimo na } \\
\text { resistência } \\
\text { de pico } \\
(\%)\end{array}$ & $\begin{array}{c}E_{\text {def }} \\
\left(\mathrm{kJ} / \mathrm{m}^{3}\right)\end{array}$ & $\begin{array}{c}\mathrm{c}^{\prime} \\
(\mathrm{kPa})\end{array}$ & $\begin{array}{l}\phi^{\prime} \\
\left({ }^{\circ}\right)\end{array}$ \\
\hline \multirow{9}{*}{ Areia Sisal } & \multirow{3}{*}{2} & 50 & 263.40 & 20.00 & 94.16 & 40.34 & \multirow{3}{*}{4.98} & \multirow{3}{*}{43.31} \\
\hline & & 100 & 493.88 & 20.00 & 92.98 & 75.25 & & \\
\hline & & 150 & 694.27 & 19.00 & 91.98 & 102.88 & & \\
\hline & \multirow{3}{*}{4} & 50 & 204.39 & 17.50 & 50.66 & 35.32 & \multirow{3}{*}{9.86} & \multirow{3}{*}{39.39} \\
\hline & & 100 & 413.68 & 20.00 & 61.64 & 68.01 & & \\
\hline & & 150 & 548.82 & 19.00 & 51.76 & 87.54 & & \\
\hline & \multirow{3}{*}{8} & 50 & 186.00 & 18.00 & 37.10 & 33.20 & \multirow{3}{*}{10.92} & \multirow{3}{*}{36.47} \\
\hline & & 100 & 344.44 & 16.50 & 34.59 & 60.48 & & \\
\hline & & 150 & 478.76 & 16.00 & 33.38 & 81.32 & & \\
\hline \multirow{9}{*}{ Areia Curauá } & \multirow{3}{*}{2} & 50 & 290.99 & 20.00 & 114.49 & 41.37 & \multirow{3}{*}{47.99} & \multirow{3}{*}{32.66} \\
\hline & & 100 & 413.66 & 19.50 & 61.64 & 71.82 & & \\
\hline & & 150 & 525.40 & 16.50 & 45.28 & 91.03 & & \\
\hline & \multirow{3}{*}{4} & 50 & 233.17 & 20.00 & 71.87 & 38.10 & \multirow{3}{*}{29.93} & \multirow{3}{*}{33.92} \\
\hline & & 100 & 376.69 & 19.50 & 47.19 & 65.31 & & \\
\hline & & 150 & 484.96 & 16.00 & 34.10 & 82.95 & & \\
\hline & \multirow{3}{*}{8} & 50 & 181.35 & 13.00 & 33.68 & 32.58 & \multirow{3}{*}{13.33} & \multirow{3}{*}{35.72} \\
\hline & & 100 & 358.22 & 14.50 & 39.97 & 62.56 & & \\
\hline & & 150 & 458.69 & 13.00 & 26.83 & 78.53 & & \\
\hline
\end{tabular}

A Tabela 7.2 reforça um outro ponto já verificado ateriormente, as perdas na maxima tensão desviadora e na capacidade de absorção de energia foram mais pronunciada na maior tensão confinante aplicada $(150 \mathrm{kPa})$, indicando a fragilidade das fibras à própria densificação da amostra na etapa de adensamento do ensaio triaxial convecional, ou seja, o atrito físico que ocorre entre as particulas de solo durante esta etapa provoca maiores danos na fibra quando esta já se encontra fragilizada.

O envelhecimento natural afetou os parâmetros de resistência dos compósitos. Os compósitos areia-sisal resultaram na redução do ângulo de atrito e manifestação do intercepto coesivo, enquanto que os compósitos areia-curauá o comportamento foi ao contrário, acentuado aumento do valor do intercepto coesivo com posterior queda e acentuada perda do ângulo de atrito com o amento do tempo de envelhecimento.

Nos compósitos areia-sisal, o aumento no valor do intercepto coesivo (c') e a diminuição do valor do ângulo de atrito interno $\left(\phi^{\prime}\right)$ com o aumento do tempo de exposição ocorrem devido a essa maior perda de resistência ocorrida na tensão confinante de $150 \mathrm{kPa}$. Perdas na resistência também ocorreram nas menores tensões confinantes aplicadas, mas não na mesma magnitude, resultando na diminuição da inclinação das envoltórias de resistência e consequente aumento do intercepto coesivo. O aumento no valor c' também poderia ser associado à presença de biofilme, que resultou em mudança da estrutura detectada em $\varepsilon_{v}$ vs $\varepsilon_{a}$ e em e vs p'. 
Nos compósitos areia-curauá, o acentuado aumento do valor do intercepto coesivo e acentuada perda do ângulo de atrito após 2 meses de exposição estariam associados à grande mudança ocorrida no comportamento tensão vs deformação deste período na tensão de confinamento de $150 \mathrm{kPa}$. Como após este período não ocorreram mais grandes alterações na tensão de confinamento de $150 \mathrm{kPa}$, e os efeitos do envelhecimento passaram a se refletir na menor tensão de confinamento $(50 \mathrm{kPa})$ observa-se a diminuição do valor do intercepto coesivo.

Visando melhorar a visualização dos efeitos do envelhecimento natural sobre o comportamento mecânico dos compósitos areia-fibras vegetais foi elaborada a Figura 7.3. Nela fica clara a diferença existente quanto a taxa com a qual a tensão desviadora de ruptura e a capacidade de absorção de energia de deformação declinam com o tempo entre os compósitos com fibras de sisal e curauá. Os compósitos com fibra de curauá perdem resistência e tenacidade com maior rapidez e maior magnitude do que o compósito com fibra de sisal.

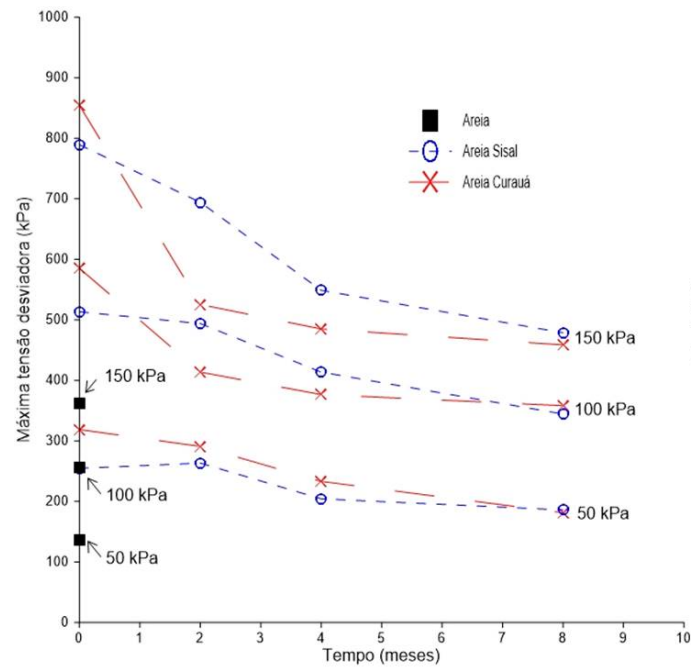

(a)

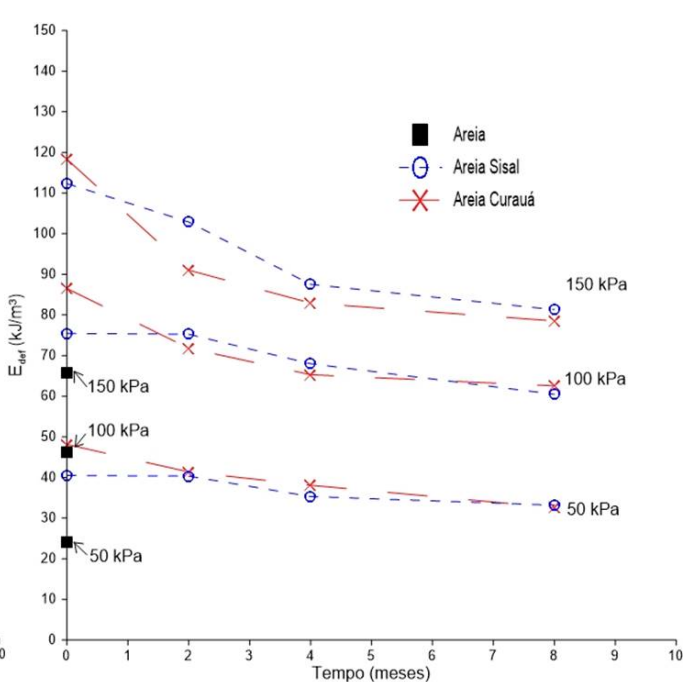

(b)

Figura 7.3: Propriedades mecânicas da areia e dos compósitos areia-fibras vegetais sem tratamento expostos ao intemperismo: (a)Máxima tensão desviadora e (b)Capacidade de absorção de energia $\left(E_{d e f}\right)$

Essas perdas, em ambas as fibras, ocorrem de modo acentuado até os 4 meses de exposição, mantendo-se estável até os 8 meses. Mesmo tendo sua durabilidade afetada pela exposição aos agentes climáticos por 8 meses, os compositos areia-fibras vegetais mantiveram resistência e capacidade de absorção de energia de deformação maiores que as da amostra sem reforço. 
Os parâmetros de resistência dos compósitos expostos ao envelhecimento natural também foram organizados em um gráfico para melhor visualização do seu comportamento no passar tempo (Figura 7.4).

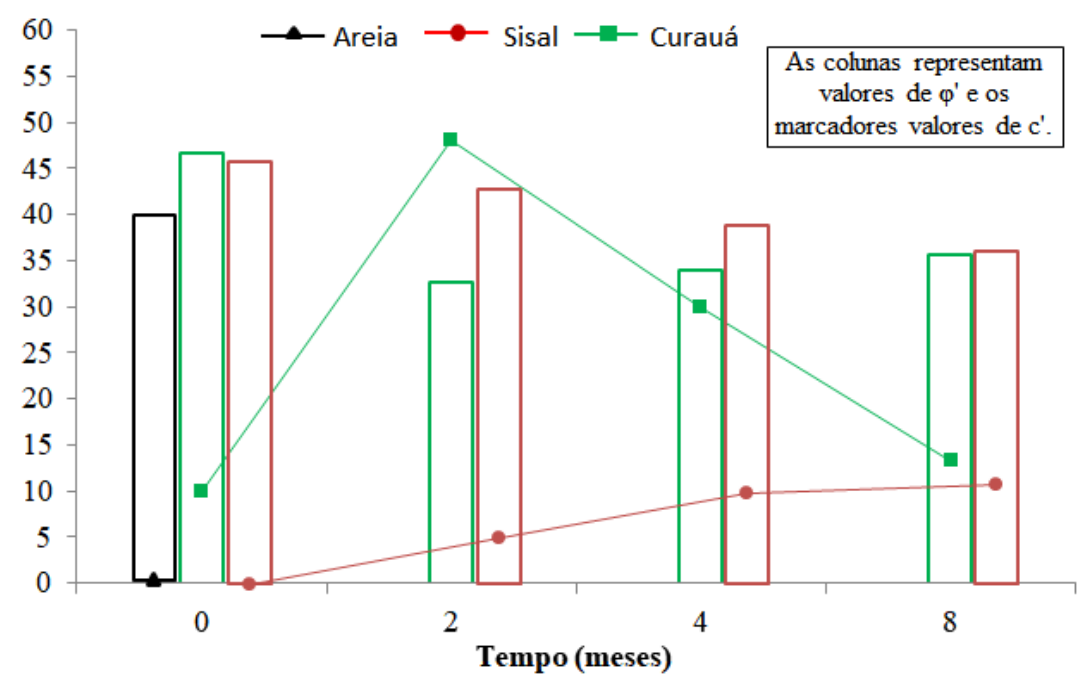

Figura 7.4: Parâmetros de resistência da areia e dos compósitos areia-fibras vegetais sem tratamento expostos ao intemperismo

No entanto, mesmo sendo afetados pela exposição aos agentes climáticos e pelo tempo, ambos os valores de c' e $\phi^{\prime}$ permaneceram maiores que os observados na amostra arenosa sem reforço, também apresentados na figura.

Após analisar os resultados obtidos julgamos que as etapas adotadas para avaliar os efeitos do envelhecimento no comportamento mecânico dos compósitos areia/ fibra vegetal em laboratório foram consideradas como de pior condição, já que as amostras foram densificadas na etapa de adensamento do ensaio triaxial convencional após as fibras se encontrarem fragilizadas. Em uma situação de obra, a densificação de um aterro por exemplo, ocorreria com as fibras gozando de toda suas propriedades mecânicas, físicas e químicas, o que lhe daria maior proteção ao atrito físico que ocorre entre as particulas de solo durante esta etapa.

Outro ponto que direciona as etapas adotadas neste estudo como de pior condição foi a própria densidade relativa adotada. A densidade relativa de $50 \%$ permite uma maior permeabilidade da água da chuva e consequentemente uma condição de elevada umidade além de manter um alto grau de oxigenação, condições ideais para a proliferação de microorganismos. Em uma situação de aterro a densidade relativa seria muito maior além de ser uma prática a impermeabilizaçao superficial deste aterro ou um sistema de drenagem para coleta e direcionamento da água que incide sobre esta obra de terra para distante dela. 


\subsection{2}

\section{Compósitos expostos com as fibras tratadas superficialmente}

Neste item são apresentados e analisados os resultados de trinta e seis ensaios triaxiais convencionais, com tensões confinantes de 50, 100 e 150kPa, realizados em compósitos de areia reforçada com fibras vegetais tratadas e aleatoriamente distribuidas na matriz expostos aos agentes climáticos por 8 meses. Buscou-se investigar e identificar o efeito dos tratamentos superficiais aplicados nas fibras na durabiliadade das propriedades mecânicas dos compósitos expostos ao evelhecimento natural.

As Figuras 7.5 e 7.6 apresentam em conjunto quatro gráficos obtidos para a série de ensaios triaxiais nos compósitos com as fibras de sisal tratadas com sílica e polímero, respectivamente, expostos aos agentes climáticos e ao tempo: q vs $\varepsilon_{a}$, p' vs q, $\varepsilon_{v}$ vs $\varepsilon_{a}$, e e vs p'. Os valores de índice de vazios após adensamento e ao final do ensaio além da umidade final, são apresentados na Tabela 7.3.

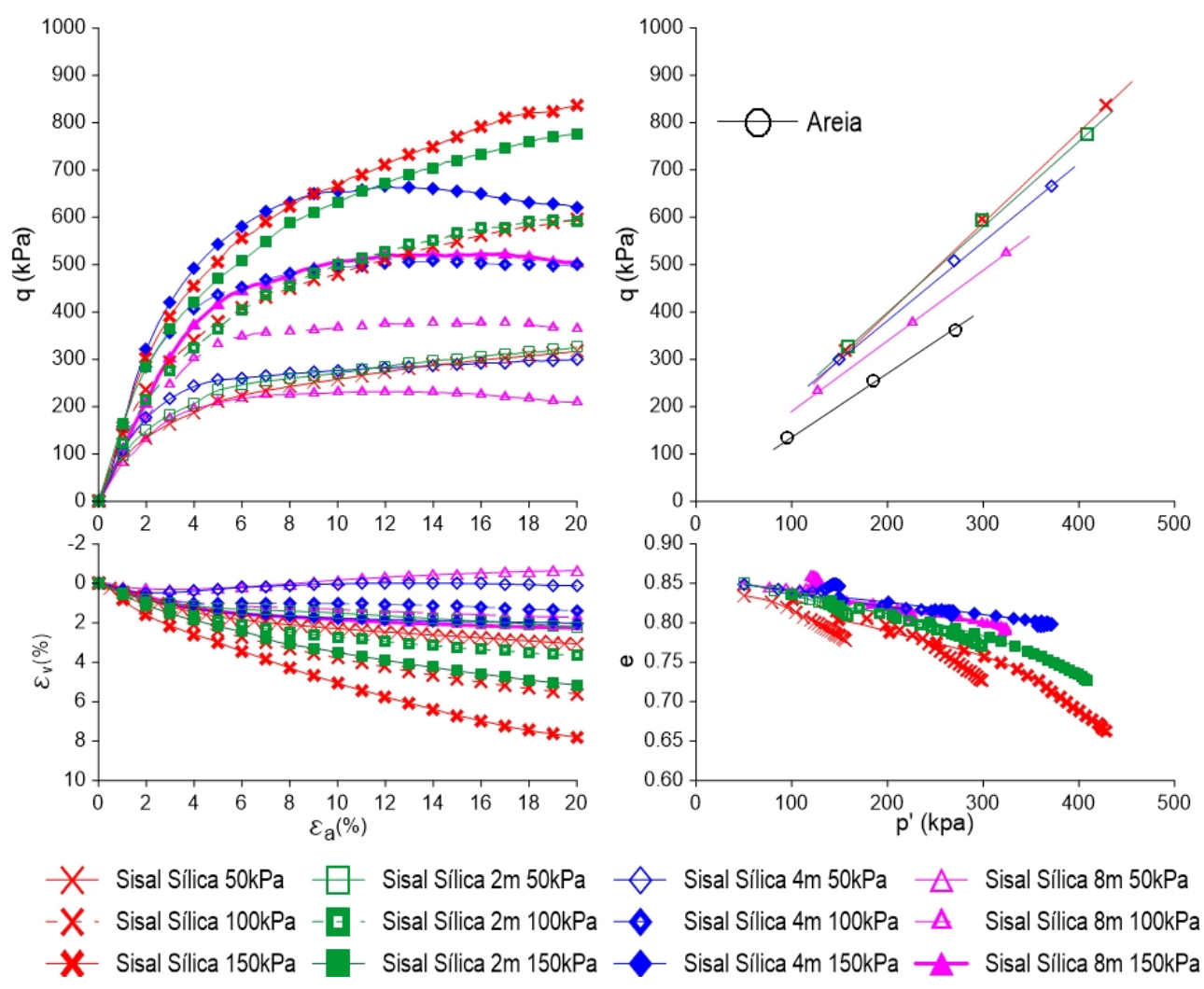

Figura 7.5: Resultado dos ensaios triaxiais convencionais nos compósitos areiasisal tratada com sílica expostos ao intemperismo e ao tempo

Analisando as curvas apresentadas e comparando com a Figura 7.1 é possível observar que os compósitos areia-sisal tratada com sílica e polímero também foram afetados pelo envelhecimento natural. Ocorreram similaridades 
quanto a perda gradual do comportamento de endurecimento com o aumento do tempo de exposição, quanto a perda do comportamento de endurecimento ter sido mais pronunciada na maior tensão confinante aplicada (150kPa) e quanto a mudança na estrutura do compósito ao ser observado a diminuição do comportamento de contração a medida que o tempo de exposição foi aumentando. Tais efeitos não poderiam ter sido diferentes já que as fibras tratadas também se tornaram mais frágeis ao toque e também sofreram perda de massa com o aumento do tempo de exposição. A mundança na estrutura do compósito poderia ser associada à presença do biofilme.
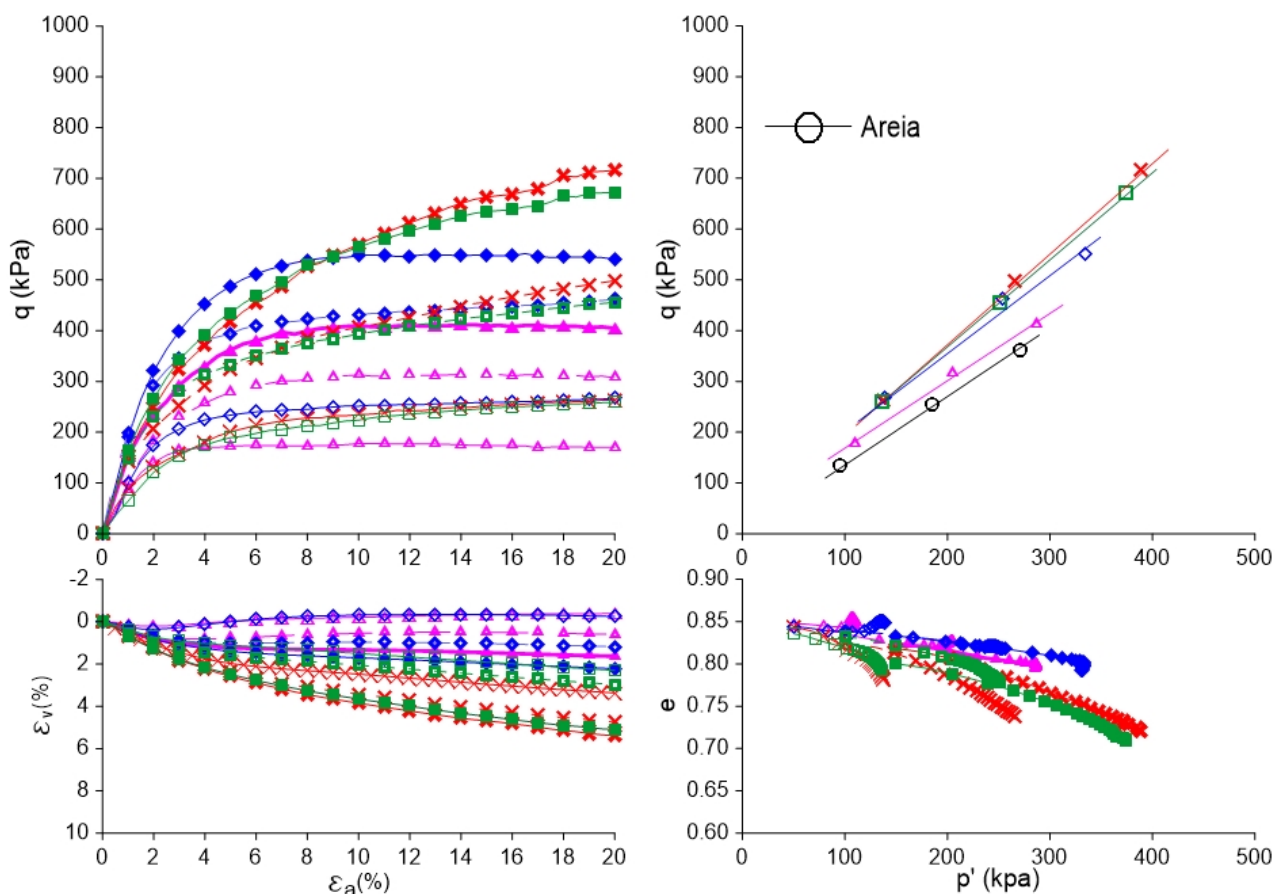

$X$ Sisal Polimero 50kPa $\square$ Sisal Polimero $2 \mathrm{~m} 50 \mathrm{kPa} \leadsto$ Sisal Polimero 4m 50kPa $\triangle$ Sisal Polimero $8 \mathrm{~m} 50 \mathrm{kPa}$

-X Sisal Polímero 100kPa - ES Sisal Polímero $2 \mathrm{~m} 100 \mathrm{kPa}-\vartheta$ Sisal Polímero $4 \mathrm{~m} 100 \mathrm{kPa} \triangle$ Sisal Polímero $8 \mathrm{~m} 100 \mathrm{kPa}$

X Sisal Polimero $150 \mathrm{kPa}-$ - Sisal Polimero $2 \mathrm{~m} 150 \mathrm{kPa}$

Sisal Polimero 4m 150kPa $\leftarrow$ Sisal Polimero $8 \mathrm{~m} 150 \mathrm{kPa}$

Figura 7.6: Resultado dos ensaios triaxiais convencionais nos compósitos areiasisal tratada com polímero expostos ao intemperismo e ao tempo

No entanto, a cinética e a forma de como estes efeitos ocorreram foi diferenciado entre os compósitos com e sem tratamento. Analisando as curvas q vs $\varepsilon_{a}$ é possível observar que após dois meses de exposição, o comportamento das curvas é semelhante ao dos compósitos no tempo zero, em todas as tensões confinates avaliadas. Após 4 meses, as curvas passam a apresentar aumento da rigidez inicial e perda do comportamento de endurecimento, em todas as tensões confinantes avaliadas sendo que exibindo maiores variações na tensão confinante de $150 \mathrm{kPa}$. Aos 8 meses de exposição, esse aumento de rigidez inicial é perdido e a maior perda de resistência entre dois tempos 
de exposição analisados ocorre, em todas as tensões confinantes avaliadas, sendo que exibindo maiores variações na tensão confinante de $150 \mathrm{kPa}$. Estas observações sugerem que os tratamentos superficiais com sílica e polímero influênciaram na durabilidade dos compósitos principalmente nos 4 primeiros meses de exposição.

Tabela 7.3: Índices físicos após o adensamento e no final do ensaio, dos corpos de prova de compósitos areia-sisal tratada expostos ao intemperismo e ao tempo

\begin{tabular}{|c|c|c|c|c|c|c|}
\hline \multirow[b]{2}{*}{ Fibra } & \multirow[b]{2}{*}{ Tratamento } & \multirow{2}{*}{$\begin{array}{c}\text { Tempo de } \\
\text { exposição } \\
\text { (meses) }\end{array}$} & \multirow[b]{2}{*}{$\sigma_{3}^{\prime}$} & \multirow{2}{*}{$\begin{array}{c}\text { Após o } \\
\text { adensamento }\end{array}$} & \multicolumn{2}{|c|}{$\begin{array}{c}\text { Após o } \\
\text { cisalhamento }\end{array}$} \\
\hline & & & & & $e_{\text {final }}$ & $\begin{array}{c}w_{\text {final }} \\
(\%)\end{array}$ \\
\hline \multirow{18}{*}{ Sisal } & \multirow{9}{*}{ Sílica } & \multirow{3}{*}{2} & 50 & 0.850 & 0.809 & 27.027 \\
\hline & & & 100 & 0.836 & 0.769 & 25.223 \\
\hline & & & 150 & 0.821 & 0.727 & 25.339 \\
\hline & & \multirow{3}{*}{4} & 50 & 0.848 & 0.846 & 27.291 \\
\hline & & & 100 & 0.834 & 0.809 & 25.696 \\
\hline & & & 150 & 0.832 & 0.795 & 24.785 \\
\hline & & \multirow{3}{*}{8} & 50 & 0.848 & 0.860 & 27.019 \\
\hline & & & 100 & 0.837 & 0.805 & 26.803 \\
\hline & & & 150 & 0.828 & 0.786 & 26.243 \\
\hline & \multirow{9}{*}{ Polímero } & \multirow{3}{*}{2} & 50 & 0.836 & 0.793 & 26.773 \\
\hline & & & 100 & 0.833 & 0.778 & 25.028 \\
\hline & & & 150 & 0.800 & 0.708 & 24.522 \\
\hline & & \multirow{3}{*}{4} & 50 & 0.844 & 0.849 & 26.381 \\
\hline & & & 100 & 0.839 & 0.817 & 26.820 \\
\hline & & & 150 & 0.833 & 0.792 & 25.338 \\
\hline & & \multirow{3}{*}{8} & 50 & 0.848 & 0.855 & 26.362 \\
\hline & & & 100 & 0.836 & 0.825 & 26.061 \\
\hline & & & 150 & 0.824 & 0.794 & 25.035 \\
\hline
\end{tabular}

A Tabela 7.4 quantifica as observações feitas nas Figuras 7.5 e 7.6. Nela são apresentados os valores obtidos para tensão desviadora e deformação axial de ruptura, o aumento de resistência de pico obtido pela presença das fibras com relação a amostra arenosa, a capacidade de absorção de energia $\left(E_{\text {def }}\right)$ e os parâmetros de resistência ao cisalhamento (c' e $\left.\phi^{\prime}\right)$.

Observa-se que o envelhecimento natural afetou os compósitos reforçados com fibras de sisal tratadas com sílica e polímero de modo diferenciado. Enquanto que o compósito com fibras tratadas com sílica continuam contribuindo como elemento de reforço com 44-71\% acima da resistência de pico da amostra arenosa, o compósito com fibras tratadas com polímero contribuem com $13-31 \%$ ao final de 8 meses de exposição. 
Comparando esses valores com os apresentados na Tabela 7.2, onde as fibras sem tratamento superficial contribuem com $33 \%$ da resistência da amostra arenosa após 8 meses de exposição, subentende-se que o tratamento com sílica contribuiu para o aumento da durabilidade do compósito. Este resultado condiz com a observação das fibras retiradas dos compósitos (i.e. as fibras tratadas com sílica foram encontradas em melhores condições e em maior quantidade após 8 meses de exposição).

Tabela 7.4: Valores das propriedades mecânicas e dos parâmetros de resistência para os compósitos areia-fibras de sisal tratadas expostos ao intemperismo.

\begin{tabular}{|c|c|c|c|c|c|c|c|c|}
\hline Tratamento & $\begin{array}{c}\text { Tempo } \\
\text { exposição } \\
\text { (meses) }\end{array}$ & $\begin{array}{c}\sigma_{3}^{\prime} \\
(\mathrm{kPa})\end{array}$ & $\begin{array}{c}\text { Tensão } \\
\text { desviadora } \\
\text { de ruptura } \\
(\mathrm{kPa})\end{array}$ & $\begin{array}{c}\text { Deformação } \\
\text { axial } \\
(\%)\end{array}$ & $\begin{array}{c}\text { Acréscimo na } \\
\text { resistência } \\
\text { de pico } \\
(\%)\end{array}$ & $\begin{array}{c}E_{\text {def }} \\
\left(\mathrm{kJ} / \mathrm{m}^{3}\right)\end{array}$ & $\begin{array}{c}\mathrm{c}^{\prime} \\
(\mathrm{kPa})\end{array}$ & $\begin{array}{l}\phi^{\prime} \\
\left({ }^{\circ}\right)\end{array}$ \\
\hline \multirow{9}{*}{ Sílica } & \multirow{3}{*}{2} & 50 & 325.77 & 20.00 & 140.13 & 50.42 & \multirow{3}{*}{23.64} & \multirow{3}{*}{43.81} \\
\hline & & 100 & 595.07 & 20.00 & 132.52 & 89.26 & & \\
\hline & & 150 & 776.64 & 20.00 & 114.75 & 114.40 & & \\
\hline & \multirow{3}{*}{4} & 50 & 299.21 & 20.00 & 120.55 & 51.00 & \multirow{3}{*}{28.39} & \multirow{3}{*}{40.39} \\
\hline & & 100 & 507.89 & 14.50 & 98.46 & 88.06 & & \\
\hline & & 150 & 666.15 & 12.00 & 84.20 & 112.24 & & \\
\hline & \multirow{3}{*}{8} & 50 & 232.03 & 11.50 & 71.03 & 40.54 & \multirow{3}{*}{21.80} & \multirow{3}{*}{36.36} \\
\hline & & 100 & 377.22 & 17.00 & 47.40 & 64.27 & & \\
\hline & & 150 & 523.29 & 17.00 & 44.70 & 87.25 & & \\
\hline \multirow{9}{*}{ Polímero } & \multirow{3}{*}{2} & 50 & 258.93 & 20.00 & 90.86 & 41.81 & \multirow{3}{*}{10.76} & \multirow{3}{*}{42.37} \\
\hline & & 100 & 455.57 & 20.00 & 78.01 & 72.65 & & \\
\hline & & 150 & 672.18 & 20.00 & 85.87 & 102.16 & & \\
\hline & \multirow{3}{*}{4} & 50 & 266.73 & 20.00 & 96.61 & 47.34 & \multirow{3}{*}{34.19} & \multirow{3}{*}{36.39} \\
\hline & & 100 & 462.47 & 20.00 & 80.71 & 79.82 & & \\
\hline & & 150 & 552.07 & 16.50 & 52.66 & 97.29 & & \\
\hline & \multirow{3}{*}{8} & 50 & 177.93 & 10.50 & 31.16 & 32.56 & \multirow{3}{*}{18.18} & \multirow{3}{*}{32.70} \\
\hline & & 100 & 314.83 & 14.50 & 23.02 & 55.30 & & \\
\hline & & 150 & 411.95 & 14.50 & 13.91 & 84.30 & & \\
\hline
\end{tabular}

O envelhecimento natural afetou mais significamente os compósitos areiasisal tratadas a partir dos 4 meses de exposição, ou seja, foi apenas nos ensaios feitos nos compósitos expostos por 8 meses que se registrou as maiores variações de resistência e $E_{d e f}$.

O envelhecimento natural afetou os parâmetros de resistência dos compósitos areia-sisal tratadas. Em geral, o aumento do tempo de exposição resultou em redução do ângulo de atrito e aumento do intercepto coesivo. O aumento no valor do intercepto coesivo (c') e a diminuição do valor do ângulo de atrito interno $\left(\phi^{\prime}\right)$ com o aumento do tempo de exposição ocorrem devido a essa maior perda de resistência ocorrida na tensão confinante de $150 \mathrm{kPa}$. Perdas na resistência de pico também ocorreram nas menores tensões confinantes aplicadas, mas não na mesma magnitude, resultando na diminuição da inclinação da envoltória de ruptura. O aumento no valor c' também poderia ser associado à presença de biofilme, que resultou em mudança da estrutura detectada em $\varepsilon_{v}$ vs $\varepsilon_{a}$ e em e vs p'.

Visando melhorar a visualização dos efeitos do envelhecimento natural sobre o comportamento mecânico dos compósitos areia-fibras de sisal tratadas 
foi elaborada a Figura 7.7. Nela fica clara a melhoria proporcionada pelo tratamento superficial com sílica na durabilidade dos compósitos areia-fibra de sisal e como este tratamento influênciou na taxa com a qual a tensão desviadora de ruptura e a capacidade de absorção de energia declinam com o tempo, principalmente até os 4 meses de exposição.

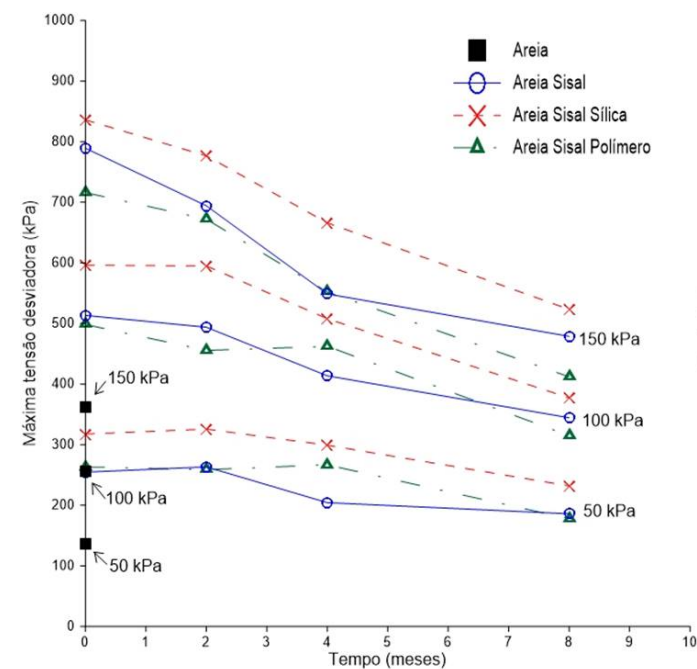

(a)

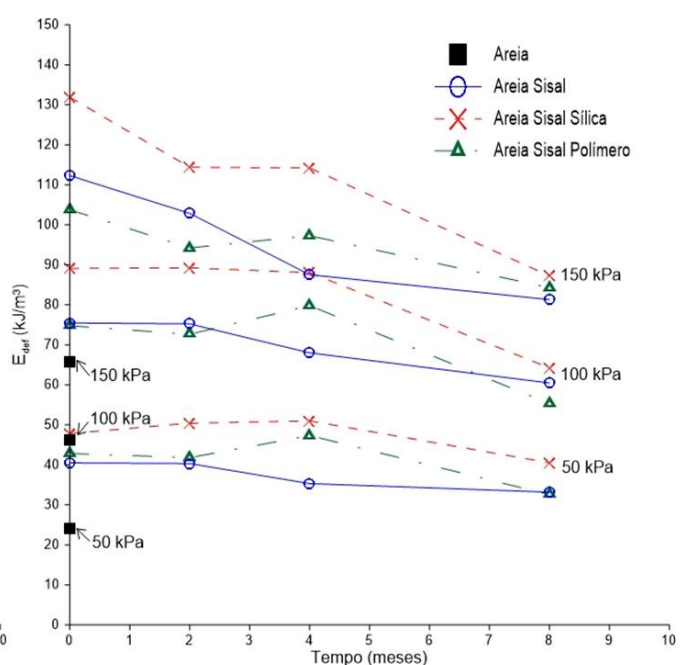

(b)

Figura 7.7: Propriedades mecânicas da areia e dos compósitos areia-fibra de sisal tratada expostos ao intemperismo: (a) Máxima tensão desviadora e (b) Capacidade de absorção de energia $\left(E_{\text {def }}\right)$

Os parâmetros de resistência dos compósitos areia-sisal tratadas expostos ao envelhecimento natural também foram organizados em um gráfico para melhor visualização do seu comportamento no passar tempo (Figura 7.8).

Esta figura reforça a já observada e discutida tendência de redução do ângulo de atrito e aumento do intercepto coesivo com o aumento do tempo de exposição dos compósitos as intempéries. Reforça a positiva contribuição do tratamento superficial das fibras com sílica na durabilidade do compósito, onde em todos os tempos analisados manteve um dos parâmetros de resistência superior ao do compósito areia-sisal sem tratamento.

Apesar destes compósitos terem sido afetados pela exposição aos agentes climáticos e pelo tempo, ambos os valores de c' e $\phi^{\prime}$ permaneceram maiores que os observados na amostra arenosa sem reforço, também apresentados na figura.

As Figuras 7.9 e 7.10 apresentam em conjunto quatro gráficos obtidos para a série de ensaios triaxiais nos compósitos com as fibras de curauá tratadas com sílica e polímero, respectivamente, expostos aos agentes climáticos e ao tempo: q vs $\varepsilon_{a}$, p' vs q, $\varepsilon_{v}$ vs $\varepsilon_{a}$, e e vs p'. Os valores de índice de vazios após 
adensamento e ao final do ensaio além da umidade final, são apresentados na Tabela 7.5.

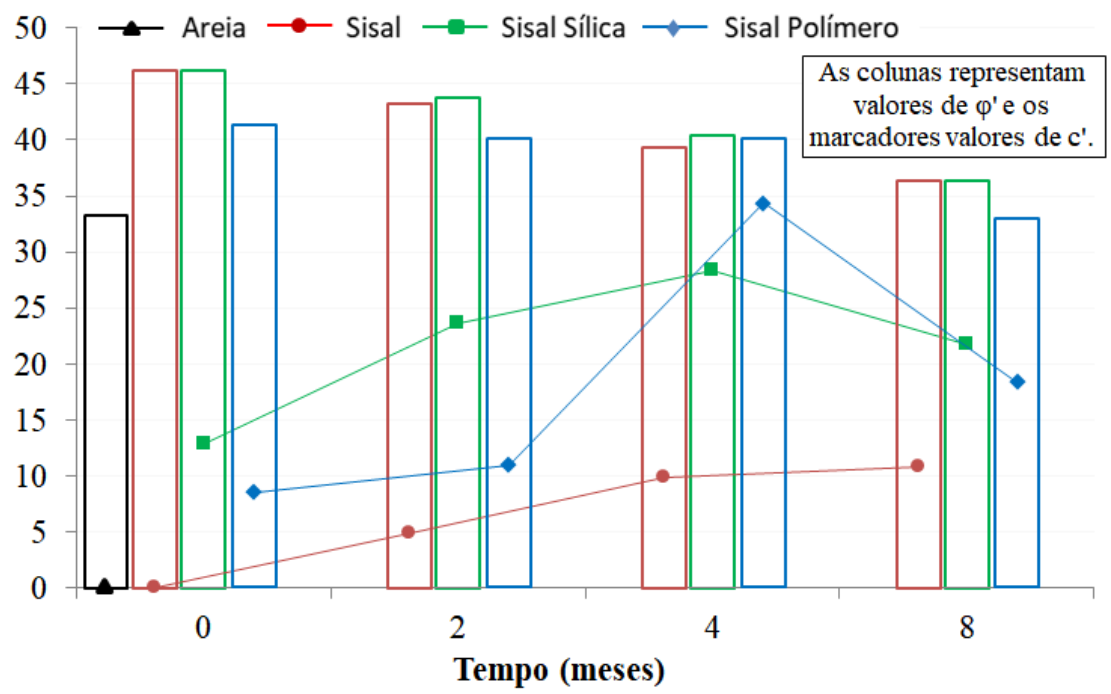

Figura 7.8: Parâmetros de resistência da areia e dos compósitos areia-fibra de sisal tratada expostos ao intemperismo
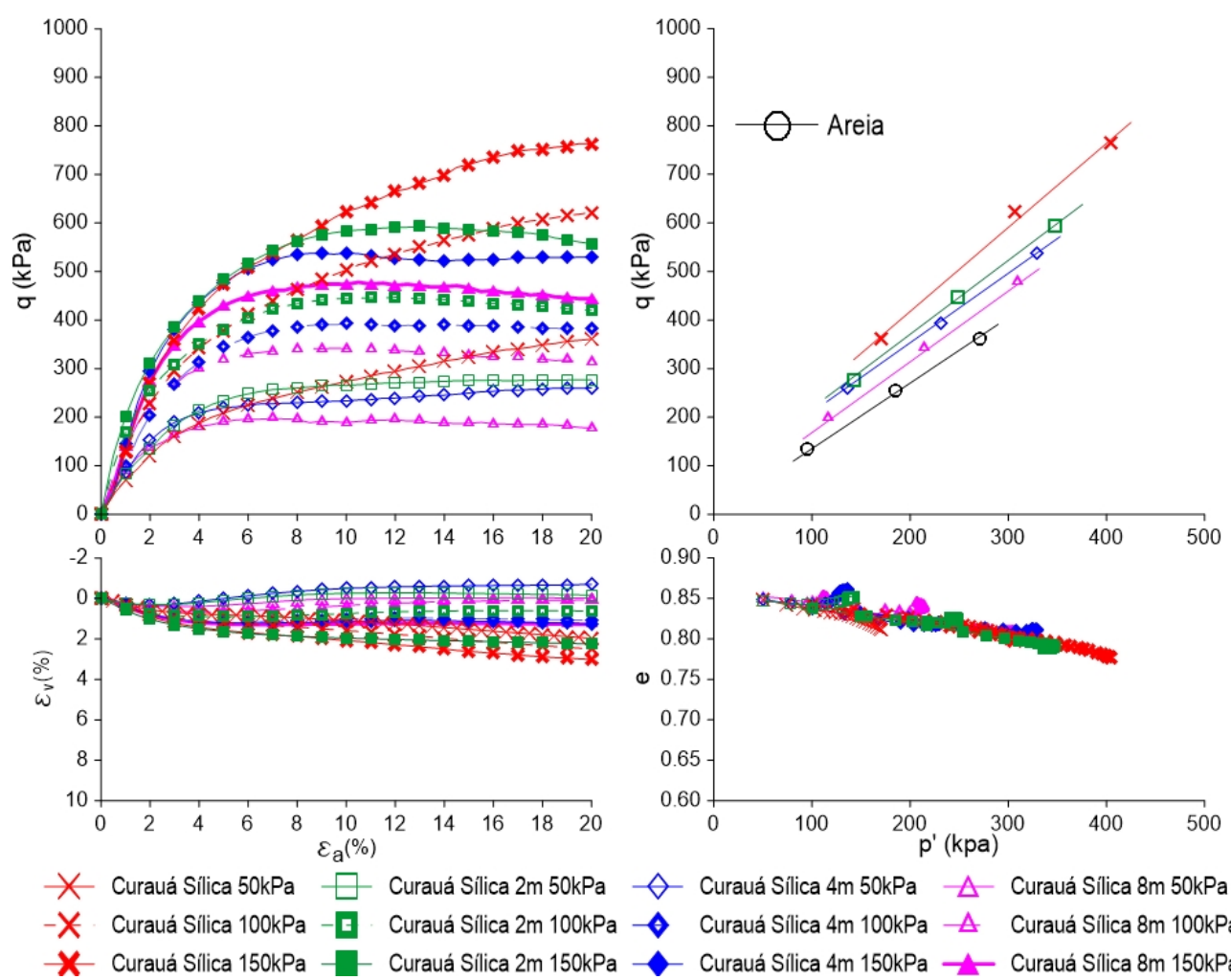

$\diamond$ Curauá Silica $4 \mathrm{~m} 50 \mathrm{kPa} \triangle$ Curauá Sílica $8 \mathrm{~m} 50 \mathrm{kPa}$

$\diamond$ Curauá Sílica $4 \mathrm{~m} 100 \mathrm{kPa} \triangle$ Curauá Silica $8 \mathrm{~m} 100 \mathrm{kPa}$

$\checkmark$ Curauá Sílica $4 \mathrm{~m} 150 \mathrm{kPa} \multimap$ Curauá Silica $8 \mathrm{~m} 150 \mathrm{kPa}$

Figura 7.9: Resultado dos ensaios triaxiais convencionais nos compósitos areiacurauá tratada com sílica expostos ao intemperismo e ao tempo

Analisando as curvas apresentadas e comparando com a Figura 7.2 é 
possível observar que os compósitos areia-curauá tratada com sílica e polímero também foram afetados pelo envelhecimento natural logo nos primeiros 2 meses de exposição. Ocorreram similaridades quanto a perda gradual do comportamento de endurecimento com o aumento do tempo de exposição e consequentemente perda na capacidade de absorção de energia, quanto a perda do comportamento de endurecimento ter sido mais pronunciada na maior tensão confinante aplicada $(150 \mathrm{kPa})$ e quanto a mudança na estrutura do compósito ao ser observado a diminuição do comportamento de contração a medida que o tempo de exposição foi aumentando. Tais efeitos não poderiam ter sido diferentes já que as fibras tratadas também se tornaram mais frágeis ao toque e também sofreram perda de massa com o aumento do tempo de exposição. A mundança na estrutura do compósito poderia ser associada à presença do biofilme.
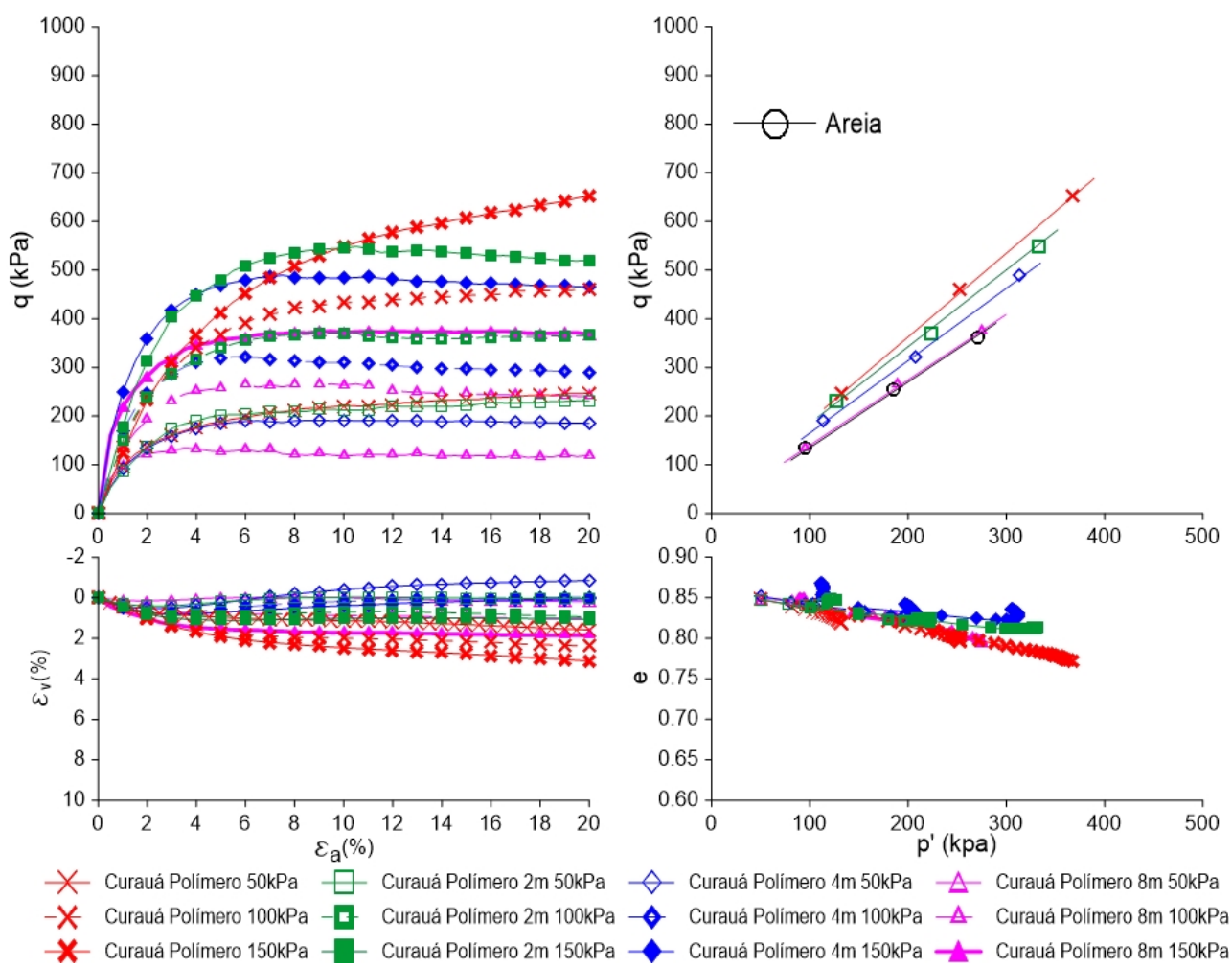

Figura 7.10: Resultado dos ensaios triaxiais convencionais nos compósitos areia-curauá tratada com polímero expostos ao intemperismo e ao tempo

No entanto, a cinética e a forma como estes efeitos ocorreram foram diferenciados entre os compósitos com e sem tratamento. As curvas referentes a 2 e 4 meses de exposição apresentaram comportamentos bem semelhantes com um aumento da rigidez inicial (mais pronunciado no compósito com fibras de curauá tratadas com polímero) e perda do comportamento de endurecimento, em todas as tensões confinantes avaliadas, sendo que exibindo maiores vari- 
ações na tensão confinante de $150 \mathrm{kPa}$. Aos 8 meses de exposição, o aumento de rigidez inicial é perdido e continua a ocorrer perda da comportamento mecânico, em todas as tensões confinates avaliadas, sendo que exibindo maiores variações na tensão confinante de $150 \mathrm{kPa}$. A perda do comportamento mecânico ocorrida entre o tempo zero e 2 meses de exposição foi superior a ocorrida entre 2 e 4 meses e a ocorrida entre 4 e 8 meses.

Tabela 7.5: Índices físicos após o adensamento e no final do ensaio, dos corpos de prova de compósitos areia-sisal tratada expostos ao intemperismo e ao tempo

\begin{tabular}{|c|c|c|c|c|c|c|}
\hline \multirow{2}{*}{ Fibra } & \multirow{2}{*}{ Tratamento } & \multirow{2}{*}{$\begin{array}{c}\text { Tempo de } \\
\text { exposição } \\
\text { (meses) }\end{array}$} & \multirow{2}{*}{$\sigma_{3}^{\prime}$} & $\begin{array}{c}\text { Após o } \\
\text { adensamento }\end{array}$ & \multicolumn{2}{|c|}{$\begin{array}{c}\text { Após o } \\
\text { cisalhamento }\end{array}$} \\
\hline & & & & $e_{\text {adens }}$ & $e_{\text {final }}$ & $\begin{array}{c}w_{\text {final }} \\
(\%)\end{array}$ \\
\hline \multirow{18}{*}{ Curauá } & \multirow{9}{*}{ Sílica } & \multirow{3}{*}{2} & 50 & 0.848 & 0.851 & 26.307 \\
\hline & & & 100 & 0.837 & 0.826 & 25.988 \\
\hline & & & 150 & 0.828 & 0.787 & 25.743 \\
\hline & & \multirow{3}{*}{4} & 50 & 0.848 & 0.861 & 27.396 \\
\hline & & & 100 & 0.838 & 0.818 & 26.269 \\
\hline & & & 150 & 0.832 & 0.809 & 25.915 \\
\hline & & \multirow{3}{*}{8} & 50 & 0.852 & 0.853 & 26.642 \\
\hline & & & 100 & 0.845 & 0.844 & 26.373 \\
\hline & & & 150 & 0.832 & 0.808 & 25.251 \\
\hline & \multirow{9}{*}{ Polímero } & \multirow{3}{*}{2} & 50 & 0.847 & 0.847 & 27.115 \\
\hline & & & 100 & 0.838 & 0.820 & 26.109 \\
\hline & & & 150 & 0.831 & 0.812 & 25.645 \\
\hline & & \multirow{3}{*}{4} & 50 & 0.852 & 0.867 & 27.255 \\
\hline & & & 100 & 0.841 & 0.842 & 25.748 \\
\hline & & & 150 & 0.838 & 0.836 & 24.957 \\
\hline & & \multirow{3}{*}{8} & 50 & 0.849 & 0.846 & 26.425 \\
\hline & & & 100 & 0.839 & 0.820 & 25.618 \\
\hline & & & 150 & 0.827 & 0.793 & 24.769 \\
\hline
\end{tabular}

A Tabela 7.6 quantifica as observações feitas nas Figuras 7.9 e 7.10. Nela são apresentados os valores obtidos para tensão desviadora e deformação axial de ruptura, o aumento de resistência de pico obtido pela presença das fibras com relação a amostra arenosa, a capacidade de absorção de energia $\left(E_{\text {def }}\right)$ e os parâmetros de resistência ao cisalhamento, c' e $\phi^{\prime}$.

Observa-se que o envelhecimento natural afetou os compósitos reforçados com fibras de curauá tratadas com sílica e polímero de modo diferenciado. Enquanto que o compósito com fibras tratadas com sílica continuam contribuindo como elemento de reforço com $32-45 \%$ da resistência de pico da amostra arenosa, o compósito com fibras tratadas com polímero contribuem com 0-4\% ao 
final de 8 meses de exposição.

Tabela 7.6: Valores das propriedades mecânicas e dos parâmetros de resistência para os compósitos areia-fibras de curauá tratadas expostos ao intemperismo.

\begin{tabular}{|c|c|c|c|c|c|c|c|c|}
\hline Tratamento & $\begin{array}{l}\text { Tempo } \\
\text { exposição } \\
\text { (meses) }\end{array}$ & $\begin{array}{c}\sigma_{3}^{\prime} \\
(\mathrm{kPa})\end{array}$ & $\begin{array}{c}\text { Tensão } \\
\text { desviadora } \\
\text { de ruptura } \\
(\mathrm{kPa})\end{array}$ & $\begin{array}{c}\text { Deformação } \\
\text { axial } \\
(\%)\end{array}$ & $\begin{array}{c}\text { Acréscimo na } \\
\text { resistência } \\
\text { de pico } \\
(\%)\end{array}$ & $\begin{array}{c}E_{\text {def }} \\
\left(\mathrm{kJ} / \mathrm{m}^{3}\right)\end{array}$ & $\begin{array}{c}\mathrm{c}^{\prime} \\
(\mathrm{kPa})\end{array}$ & $\begin{array}{l}\phi^{\prime} \\
\left({ }^{\circ}\right)\end{array}$ \\
\hline \multirow{9}{*}{ Sílica } & \multirow{3}{*}{2} & 50 & 277.17 & 19.5 & 104.31 & 47.57 & \multirow{3}{*}{30.19} & \multirow{3}{*}{37.76} \\
\hline & & 100 & 447.23 & 12.00 & 74.75 & 77.70 & & \\
\hline & & 150 & 592.77 & 13.00 & 63.91 & 101.50 & & \\
\hline & \multirow{3}{*}{4} & 50 & 260.45 & 20.00 & 91.98 & 43.84 & \multirow{3}{*}{30.60} & \multirow{3}{*}{35.56} \\
\hline & & 100 & 392.30 & 10.00 & 53.29 & 68.25 & & \\
\hline & & 150 & 538.38 & 10.00 & 48.87 & 93.75 & & \\
\hline & \multirow{3}{*}{8} & 50 & 197.24 & 7.00 & 45.39 & 35.15 & \multirow{3}{*}{14.95} & \multirow{3}{*}{35.74} \\
\hline & & 100 & 342.33 & 9.50 & 33.76 & 60.53 & & \\
\hline & & 150 & 478.04 & 10.50 & 32.19 & 83.11 & & \\
\hline \multirow{9}{*}{ Polímero } & \multirow{3}{*}{2} & 50 & 231.62 & 20.00 & 70.73 & 39.66 & \multirow{3}{*}{16.10} & \multirow{3}{*}{37.79} \\
\hline & & 100 & 370.68 & 10.50 & 44.84 & 66.08 & & \\
\hline & & 150 & 548.57 & 10.50 & 51.69 & 95.44 & & \\
\hline & \multirow{3}{*}{4} & 50 & 191.30 & 9.00 & 41.01 & 34.92 & \multirow{3}{*}{8.78} & \multirow{3}{*}{36.82} \\
\hline & & 100 & 321.78 & 6.00 & 25.73 & 57.47 & & \\
\hline & & 150 & 489.66 & 7.50 & 35.40 & 88.99 & & \\
\hline & \multirow{3}{*}{8} & 50 & 134.50 & 3.50 & -0.86 & 23.71 & \multirow{3}{*}{4.87} & \multirow{3}{*}{33.10} \\
\hline & & 100 & 266.49 & 10.50 & 4.13 & 47.57 & & \\
\hline & & 150 & 374.75 & 11.00 & 3.62 & 69.47 & & \\
\hline
\end{tabular}

Comparando esses valores com os apresentados na Tabela 7.2, onde as fibras sem tratamento superficial continuam contribuindo como elemento de reforço com $33 \%$ da resistência de pico da amostra arenosa após 8 meses de exposição, subentende-se que o tratamento com sílica contribuiu para o aumento da durabilidade do compósito.

Analisado esses resultados e comparando com os obtidos no compósito areia-sisal tratada, pode-se sugerir que o tratamento superficial com sílica foi mais eficiente na durabilidade dos compósitos areia-sisal, já que este manteve 42-65\% da resistencia de pico acima das amostras sem reforço.

O envelhecimento natural afetou os parâmetros de resistência dos compósitos areia-curauá tratadas de modo semelhante ao observado nos compósitos areia-curauá sem tratamento. Observa-se o acentuado aumento do valor do intercepto coesivo e acentuada perda do ângulo de atrito após 2 meses de exposição que estariam associados à grande mudança ocorrida no comportamento tensão vs deformação deste período na tensão de confinamento de $150 \mathrm{kPa}$. Como após este período não ocorreram mais grandes alterações na tensão de confinamento de $150 \mathrm{kPa}$, e os efeitos do envelhecimento passaram a se refletir na menor tensão de confinamento $(50 \mathrm{kPa})$ observa-se a diminuição do valor do intercepto coesivo.

Visando melhorar a visualização dos efeitos do envelhecimento natural sobre o comportamento mecânico dos compósitos areia-fibras de curauá tratadas foi elaborada a Figura 7.11. Nela fica clara a melhoria proporcionada pelo 
tratamento superficial com sílica na durabilidade dos compósitos areia-fibra de curauá e como este tratamento influênciou na taxa com a qual a tensão desviadora de ruptura e a capacidade de absorção de energia declinam com o tempo

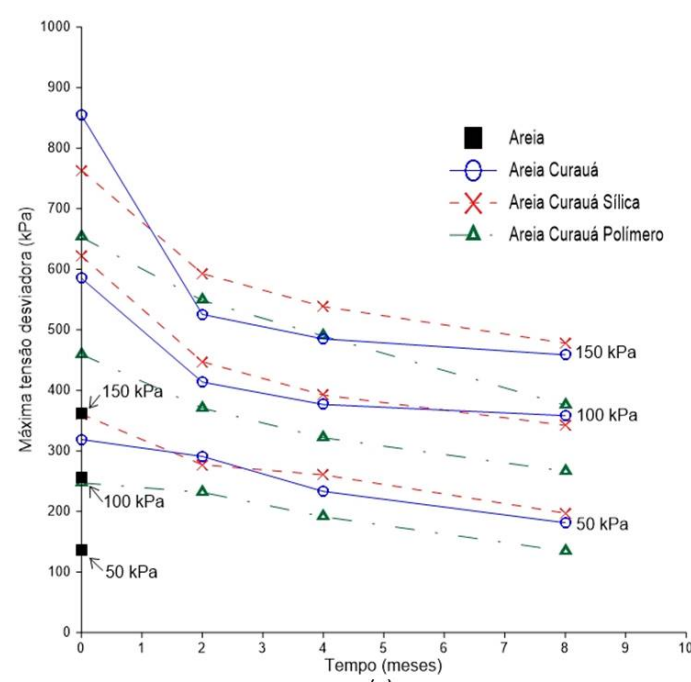

(a)

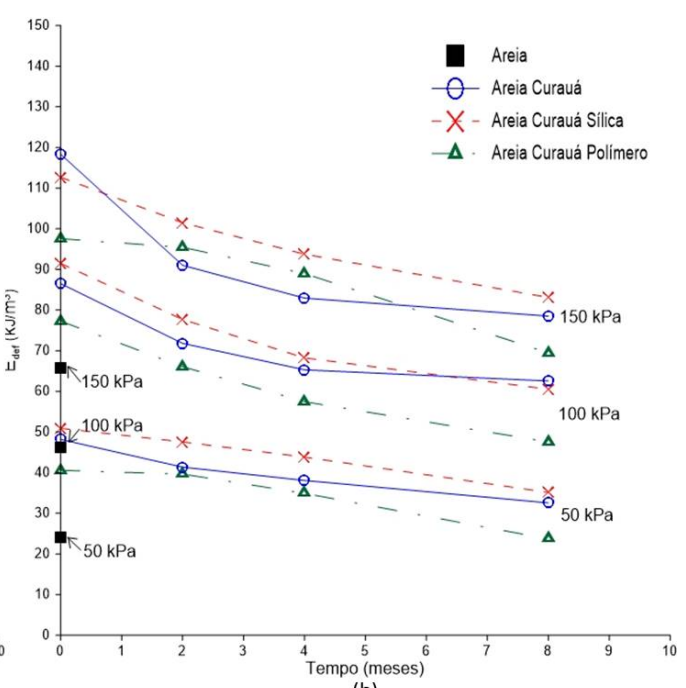

Figura 7.11: Propriedades mecânicas da areia e dos compósitos areia-fibra de curauá tratada expostos ao intemperismo: (a) Máxima tensão desviadora e (b) Capacidade de absorção de energia $\left(E_{\text {def }}\right)$

Os parâmetros de resistência dos compósitos areia-curauá tratadas expostos ao envelhecimento natural também foram organizados em um gráfico para melhor visualização do seu comportamento no decorrer do tempo (Figura 7.12).

Esta figura reforça a positiva contribuição do tratamento superficial das fibras com sílica na durabilidade do compósito, onde em todos os tempos analisados manteve um dos parâmetros de resistência superior ao do compósito areia-curauá sem tratamento.

Apesar destes compósitos terem sido afetados pela exposição aos agentes climáticos e pelo decorrer do tempo, pelo menos um dos parâmetros de resistência permaneceu maior que os observados na amostra arenosa sem reforço, também apresentados na figura. 
Capítulo 7. Durabilidade dos compósitos submetidos ao envelhecimento natural

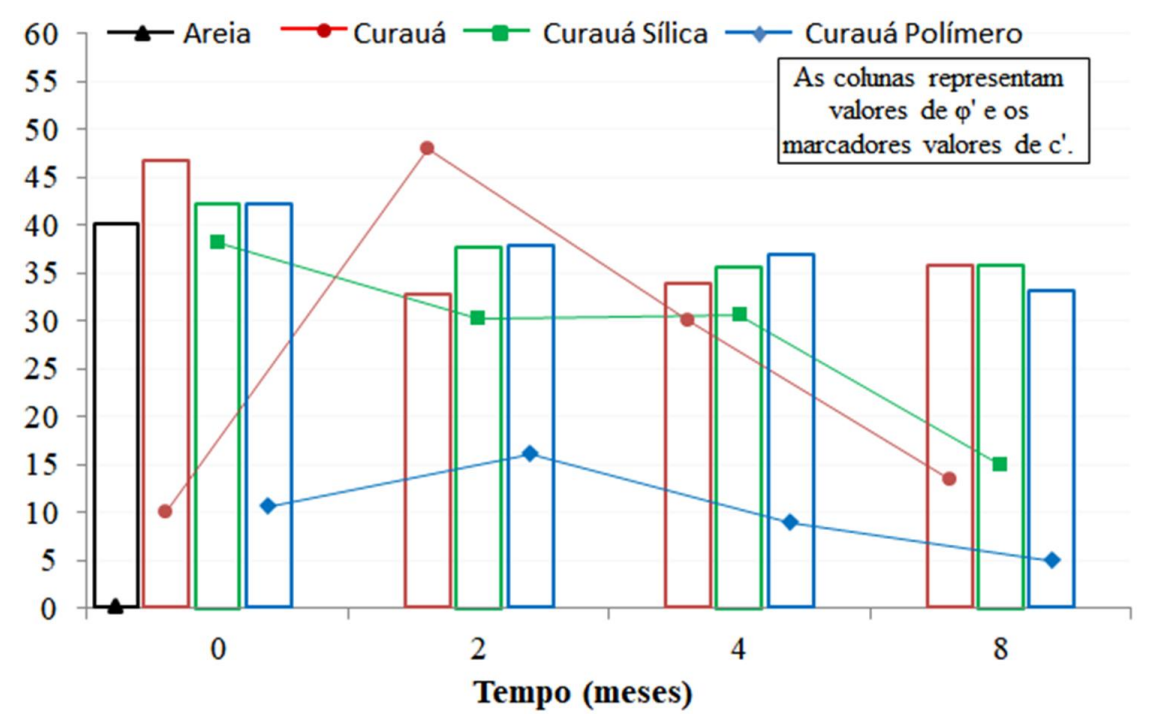

Figura 7.12: Parâmetros de resistência da areia e dos compósitos areia-fibra de curauá tratada expostos ao intemperismo 


\section{8 \\ Conclusões}

A motivação principal deste trabalho consistiu na avaliação do comportamento mecânico e da durabilidade de solos reforçados com fibras de vegetais aleatoriamente distribuídas, submetidos ao envelhecimento natural por exposição às condições ambientais diversas por 8 meses.

Para tal fim, foram selecionados um solo arenoso como a matriz do compósito, dois tipos de fibras vegetais (sisal e curauá) como elementos de reforço do compósito, e dois tipos de tratamentos de impermeabilização (sílica coloidal e copolímero de butadieno e estireno carboxilado) para melhorar a durabilidade das fibras.

O programa experimental consistiu na realização de ensaios triaxiais convencionais em amostras de areia e areia-fibras no tempo zero (de controle) e em compósitos expostos aos agentes do ambiente externo por até 8 meses, além de ensaios de tração direta, MEV, FTIR e análise de perda de massa nas fibras após cada período de exposição (60, 120 e 240 dias).

A seguir são apresentadas as conclusões, que caracterizam a relevância e originalidade da pesquisa, baseadas nos resultados apresentados e analisados nos capítulos anteriores.

- A exposição das fibras vegetais com e sem tratamento superficial ao solo, aos agentes climáticos e ao tempo resultou na perda das propriedades mecânicas e em perdas de massa (dimensões físicas) das fibras. A perda de massa das fibras ocorreu em um nivel tal que provavelmente regeu as variação observada no comportamento mecânico dos compósitos areiafibras vegetais expostos ao tempo. A perda de massa das fibras de curauá foram mais acentuadas, indicando que esta fibra é mais susceptivel à degradação em ambientes naturais do que a fibra de sisal;

- A exposição dos compósitos areia-fibras vegetais com e sem tratamento superficial aos agentes climáticos e ao tempo resultou na perda do comportamento do comportamento mecânico. Sendo que, a taxa com a qual a tensão desviadora de ruptura e a capacidade de absorção de energia de deformação declinam com o tempo é diferente entre os 
compósitos com fibras de sisal e de curauá. Os compósitos com fibra de curauá perdem resistência e tenacidade com maior rapidez e maior magnitude do que o compósito com fibra de sisal, reforçando que a fibra de curauá é mais susceptivel à degradação em ambientes naturais do que a fibra de sisal;

- A menor área de seção transversal da fibra de curauá em relação a da fibra de sisal seria a justificativa tanto do porque da adição de fibras de curauá na matriz arenosa ter contribuido mais para a melhoria do comportamento mecânico no tempo zero, quanto a sua maior susceptibilidade à degradação em ambientes naturais, a ponto de ao final de 8 meses de exposição seus valores de resistência ao cisalhamento e capacidade de absorção de energia de deformação fossem similhares aos do compósito com fibras de sisal;

- O ataque por parte de fungos e bactérias presentes no solo é apontado como o responsável pelo processo de biodegradação das fibras que resultou em sua rápida deterioração. Imagens de MEV sugerem a colonização das fibras por microrganismos filamentosos como fungos e actinomicetos e sugerem também a formação de biofilmes nas uniões fibra-grão de areia;

- O envelhecimento natural afetou o mecanismo de ruptura de todos os compósitos areia-fibras vegetais expostos aos agentes climáticos. O comportamento "strain - hardening" adquirido com a adição das fibras nas amostras de controle foi gradualmente sendo perdido com o aumento do tempo de exposição o que, consequentemente, afeta a capacidade de absorção de energia destes materiais. Essa mudança no comportamento estaria associada à perda de massa das fibras detectadas visualmente;

- O envelhecimento natural afetou a estrutura dos compósitos areia-fibras vegetais dificultando a deformação da matriz arenosa, fato registrado tanto pela diminuição da tendência de contração nas curvas variação volumétria vs deformação axial quanto pelas curvas de e vs p'. Essa mudança no comportamento estaria associada à presença de biofilme observado em imagens de MEV;

- O tratamento por impregnação superficial com sílica contribuiu na durabilidade dos compósitos, onde em todos os tempos analisados mantiveram tanto a resistência ao cisalhamento quanto a capacidade de absorção de 
energia de deformação em valores superiores ao do compósito areia-fibras vegetais sem tratamento;

- O comportamento mecânico dos compósitos de areia reforçada com fibras vegetais com e sem tratamento foram afetados pela exposição destes aos agentes climáticos diversos (envelhecimento natural) por oito meses no entanto, as fibras vegetais continuaram a contribuir como elemento de reforço;

- A análise geral dos resultados indica que as fibras vegetais podem ser usadas em obras onde o caso crítico para a estabilização ou funcionalidade da obra é imediatamente após a construção, como uma estrada de acesso construído sobre argila mole saturada, onde a função primária de qualquer reforço é permitir que a estrada seja construída. Para estes casos as fibras vegetais podem ser usadas desde que conhecidas a variação temporal de seu comportamento mecânico e/ou um tratamento adequado for aplicado para melhorar suas características.

\section{1 \\ Sugestões para trabalhos futuros}

Durante o desenvolvimento de uma tese de doutorado ou qualquer outro trabalho de pesquisa sempre se procura aprofundar um determinado assunto, buscando respostas para todas as dúvidas geradas e lacunas abertas. Porém, durante esse processo, a percepção que se tem do problema se modifica e se revelam novas alternativas que até então não haviam surgido. Muitas possibilidades acabam sendo deixadas para trás por não terem sido contempladas no cronograma inicial, por motivos de falha ou pela falta de tempo.

Em virtude disso, algumas sugestões para a ampliação do conhecimento e o prosseguimento dos estudos sobre o reforço de solos com fibras em trabalhos futuros são citados a seguir:

- Realizar análises microbiológicas após cada intervalo de tempo de exposição às intempéries;

- Verificar o efeito do envelhecimento natural em outros tipos de fibras vegetais;

- Avaliar a influência do envelhecimento natural das fibras vegetais em diferentes tipos de solos; 
- Verificar o efeito da densidade relativa na durabilidade de solos reforçados com fibras vegetais;

- Investigar outros tratamentos superficiais a serem aplicados nas fibras vegetais, buscando melhorar sua durabilidade;

- Desenvolver um modelo de previsão do comportamento mecânico e da durabilidade dos compósitos solo-fibras vegetais visando a simulação numérica. 


\section{Referências bibliográficas}

AGUILAR, J. R. T. Análise do Comportamento Mecânico de um Solo Arenoso Reforçado com Fibras de Coco. Dissertação (Mestrado) - Programa de Pós-Graduação em Engenharia Civil da Pontifícia Universidade Católica do Rio de Janeiro, 2015.

AHMAD, F.; BATENI, F.; AZMI, M. Performance evaluation of silty sand reinforced with fibres. Geotextiles and Geomembranes, Elsevier Ltd., v. 28, p. 93-99, 2010.

AL WAHAB, R.; AL-QURNA, H. Fiber reinforced cohesive soils for application in compacted earth structures. In: Proceedings of the GEOSSYNTHETICS'95 CONFERENCE. [S.I.: s.n.], 1995. v. 2, p. 433-466.

AL WAHAB, R.; EL-KEDRAH, M. Using fibers to reduce tension cracks and shrink/swell in a compacted clay. In: ASCE. Geoenvironment 2000: Characterization, Containment, Remediation, and Performance in Environmental Geotechnics. [S.I.], 1995. p. 791-805.

ALIMARDANI, M.; ABBASSI-SOURKI, F. New and emerging applications of carboxylated styrene butadiene rubber latex in polymer composites and blends: Review from structure to future prospective. v. 49, 052014.

ALVAREZ, P. J.; ILLMAN, W. A. Bioremediation and natural attenuation: process fundamentals and mathematical models. [S.I.]: John Wiley \& Sons, 2005. v. 27.

AMERICAN SOCIETY FOR TESTING AND MATERIALS. Standard Test Method for Tensile Strength and Young's Modulus of Fibers: ASTM C1557. West Conshohocken, Pennsylvania, USA.: [s.n.], 2008.

ANANDJIWALA, R. D.; JOHN, M. Sisal-cultivation, processing and products. Industrial Applications of Natural Fibres: Structure, Properties and Technical Applications, John Wiley \& Sons, Ltd, p. 181-95, 2010.

ANDERSLAND, O.; KATTAK, A. Shear strength of kaolinite/fiber soil mixtures. In: International Conference on Soil Reinforcement. Paris: [s.n.], 1979. p. p.11-16.

ASSOCIAÇÃO BRASILEIRA DE NORMAS TÉCNICAS. Solo - Análise granulométrica: NBR 7181. Rio de Janeiro: [s.n.], 1984a.

ASSOCIAÇÃO BRASILEIRA DE NORMAS TÉCNICAS. Grãos de Solo que passam na peneira de $4.8 \mathrm{~mm}$ - Determinação da massa específica: NBR 6508. Rio de Janeiro: [s.n.], 1984b. 
ASSOCIAÇÃO BRASILEIRA DE NORMAS TÉCNICAS. Solos - determinação do índice de vazios máximo de solos não-coesivos: NBR 12004. Rio de Janeiro: [s.n.], 1990.

ASSOCIAÇÃO BRASILEIRA DE NORMAS TÉCNICAS. Solos - determinação do índice de vazios mínimo de solos não-coesivos: NBR 12051. Rio de Janeiro: [s.n.], 1991.

ASSOCIAÇÃO BRASILEIRA DE NORMAS TÉCNICAS. Rochas e solos Terminologia: NBR 6502. Rio de Janeiro: [s.n.], 1995.

BAIARDO, M. et al. Surface chemical modification of natural cellulose fibers. Journal of Applied Polymer Science, Wiley Online Library, v. 83, n. 1, p. 38-45, 2002.

BARRIONUEVO, M. R. E. Biodeterioreção produzida por biofilmes de fungos e cianobactérias nas ruínas jesuíticas das Missões e avaliação do seu controle. Dissertação (Mestrado) — Universidade Federal do Rio Grande do Sul, 2004.

BISHOP, A.; HENKEL, D. J. The measurement of soil properties in the triaxial test. [S.I.]: Edward Arnold (Publishers) Ltd; London, 1962.

BOLAÑOS, R. E. Z. Comportamento Mecânico de um Solo Argiloso Reforçado com Fibras de Coco. Dissertação (Mestrado) - Pontifícia Universidade Católica do Rio de Janeiro.

BRANCATO, A. A. Effect of progressive recycling on cellulose fiber surface properties. [S.I.]: Georgia Institute of Technology, 2008.

BUDINSKI, K. Engineering materials, properties and selection. 5. ed. New Jersey: Prentice Hall International, 1996. 653 p.

BUENO, B. d. S. et al. Soil fiber reinforcement: basic understanding. In: International Symposium nn Environmental Geotechnology. [S.I.: s.n.], 1996. v. 3, p. 878-884.

CANEVAROLO, S. V. Ciência dos Polímeros. [S.I.]: Artliber Editora Ltda, 2006.

CANOVAS, M.; KAWICHE, G.; SELVA, N. Possible ways of preventing deterioration of vegetable fibres in cement mortars. In: Second international RILEM symposium proceedings, Salvador Bahia Brazil. London: Chapman and Hall. [S.I.: s.n.], 1990. p. 120-9.

CARVALHO, R.; FANGUEIRO, R.; NEVES, J. Durabilidade de fibras naturais para geotecnia. Materiais de Construção, p. 237, 2014.

CASAGRANDE, M. Estudo do comportamento de um solo reforçado com fibras de polipropileno visando o uso como base de fundações superficiais. Dissertação (Mestrado) - PPGEC/UFRGS, Porto Alegre, 2001.

CASAGRANDE, M. Comportamento de solos reforçados com fibras submetidos a grandes deformações. Tese (Tese de Doutorado em Engenharia Civil) - Escola de Engenharia - Universidade Federal do Rio Grande do Sul, Rio Grande do Sul, 2005. 
CASAGRANDE, M.; CONSOLI, N. Estudo do comportamento de um solo residual areno-siltoso reforçado com fibras de polipropileno. Solos e Rochas: Revista Latino-Americana de Geotecnia, v. 25, n. 3, p. 223-230, 2002.

CHEN, C. Triaxial compression and extension tests for fiber-reinforced silty sand. In: GEOSHANGHAI INTERNATIONAL CONFERENCE 2010. Ground Improvement and Geosynthetics. [S.I.]: American Society of Civil Engineers, 2010. p. 367-376.

CHESSON, A. Plant degradation by ruminants: parallels with litter decomposition in soils. Driven by nature: plant litter quality and decomposition, Wallingford: CAB International, c1997., 1997.

CLARAMUNT, J. et al. The hornification of vegetable fibers to improve the durability of cement mortar composites. Cement and Concrete Composites, Elsevier, v. 33, n. 5, p. 586-595, 2011.

CNPS/EMBRAPA. Manual de métodos de análise de solo. Rio de Janeiro: Embrapa Solos, 1997.

CONSOLI, N.; CASAGRANDE, M.; COOP, M. Performance of a fibre-reinforced sand at large shear strains. Géotechnique, Thomas Telford Ltd, v. 57, n. 9, p. 751-756, 2007.

CONSOLI, N. et al. Effect of relative density on plate loading tests on fibre-reinforced sand. Géotechnique, Thomas Telford Ltd, v. 59, n. 5, p. 471-476, 2009a.

CONSOLI, N. et al. Effect of material properties on the behaviour of sand-cement-fibre composites. Proceedings of the Institution of Civil Engineers-Ground Improvement, Thomas Telford Ltd, v. 8, n. 2, p. 77-90, 2004.

CONSOLI, N. C.; PRIETTO, P. D. M.; ULBRICH, L. A. The behavior of a fiber-reinforced cemented soil. Ground Improvement, London, v. 3, n. 1, p. 21-30, 1999.

COSTA, J. E. G. Estudo da degradação de geotêxteis em fibra natural. Dissertação (Mestrado) - Escola de Engenharia. Universidade do Minho., 2013.

COSTERTON, J. W. et al. Microbial biofilms. Annual Reviews in Microbiology, Annual Reviews 4139 El Camino Way, PO Box 10139, Palo Alto, CA 94303-0139, USA, v. 49, n. 1, p. 711-745, 1995.

CURCIO, D. S. Comportamento hidromecânico de compósito solo-fibra. Tese (Doutorado) - Escola de Engenharia, Programa de Pós-graduação em Engenharia Civil da UFRJ, Rio de Janeiro, 2008.

CURRIE, H. A.; PERRY, C. C. Silica in plants: Biological, biochemical and chemical studies. Annals of Botany, v. 100, n. 7, p. 1383-1389, 2007. Disponível em: <http://dx.doi.org/10.1093/aob/mcm247>.

DE CAMPOS, T. M. P. Características de Projeto e Dimensionamento de um Transdutor de Variação de Volume. Relatório Interno, RI 07/85. [S.I.], 1985. 
DEFOIRDT, N. et al. Assessment of the tensile properties of coir, bamboo and jute fibre. Composites Part A: applied science and manufacturing, Elsevier, v. 41, n. 5, p. 588-595, 2010.

DIAB, A. A. et al. Effect of compaction method on the undrained strength of fiber-reinforced clay. Soils and Foundations, 2018. ISSN 0038-0806. Disponível em: < http://www.sciencedirect.com/science/article/pii/S0038080618300131>.

DIAMBRA, A.; IBRAIM, E. Fibre-reinforced sand: interaction at the fibre and grain scale. Géotechnique, ICE Publishing, v. 65, n. 4, p. 296-308, 2015.

DIAMBRA, A. et al. Fibre reinforced sands: experiments and modelling. Geotextiles and geomembranes, Elsevier, v. 28, n. 3, p. 238-250, 2010.

DITTENBER, D. B.; GANGARAO, H. V. Critical review of recent publications on use of natural composites in infrastructure. Composites Part A: Applied Science and Manufacturing, Elsevier, v. 43, n. 8, p. 1419-1429, 2012.

DONATO, M. Medidas Diretas de Tensão em Solo Reforçado com Fibras de Polipropileno. Tese (Doutorado) — Programa de Pós-graduação em Engenharia Civil, Universidade Federal do Rio Grande do Sul., Porto Alegre, 2007.

DONATO, $M$. et al. Fibras de polipropileno como reforço para materiais geotécnicos. Solos e Rochas, São Paulo, ABMS/ABGE, v. 27, n. 2, p. 161-179, 2004.

ENDO, T.; TSURUTA, T. The effect of tree roots upon the shearing strength of soil. Annual Report of the Hokkaido Branch, Tokyo Forest Experimental Station, v. 18, p. 167-182, 1969.

FATANI, M.; BAUER, G.; AL-JOULANI, N. Reinforcing soil with aligned and randomly oriented metallic fibers. Geotechnical Testing Journal, ASTM International, v. 14, n. 1, p. 78-87, 1991.

FERREIRA, S. Influência do Tratamento de Molhagem e Secagem na Aderência Fibra-Matriz e no Comportamento Mecânico de Compósitos Cimentícios Reforçados Randomicamente com Fibras de Sisal. Dissertação (Mestrado) Programa de Pós-graduação em Engenharia Civil e Ambiental, UEFS, Bahia, 2012.

FERREIRA, S. R. et al. Effect of hornification on the structure, tensile behavior and fiber matrix bond of sisal, jute and curauá fiber cement based composite systems. Construction and Building Materials, Elsevier, v. 139, p. 551-561, 2017.

FESTUGATO, L. Análise do comportamento mecânico de um solo micro-reforçado com fibras de distintos índices aspecto. Dissertação (Mestrado) - Programa de Pós-Graduação em Engenharia Civil da UFRGS., 2008.

FEUERHARMEL, M. Comportamento de solos reforçados com fibras de polipropileno. Dissertação (Mestrado) - Programa de Pós-Graduação em Engenharia Civil da UFRGS., Porto Alegre, 2000. 
FIDELIS, M. Desenvolvimento e caracterização mecânica de compósitos cimentícios têxteis reforçados com fibras d e juta. Tese (Doutorado) Universidade Federal do Rio de Janeiro. Programa de Pós-graduação em Engenharia Civil, COPPE, 2014.

FIDELIS, M. E. A. et al. The effect of fiber morphology on the tensile strength of natural fibers. Journal of Materials Research and Technology, Elsevier, v. 2, n. 2, p. 149-157, 2013.

FREITAG, D. R. Soil randomly reinforced with fibers. Journal of Geotechnical Engineering, American Society of Civil Engineers, v. 112, n. 8, p. 823-826, 1986.

GHAVAMI, K.; TOLÊDO FILHO, R. D.; BARBOSA, N. P. Behaviour of composite soil reinforced with natural fibres. Cement and Concrete Composites, Elsevier, v. 21 , n. 1 , p. 39-48, 1999.

GIRARDELLO, V. Ensaios de placa em areias não saturadas reforçada com fibras. Dissertação (Mestrado) - Universidade Federal do Rio Grande do Sul. Escola de Engenharia. Programa de Pós-Graduação em Engenharia Civil, 2010.

GRAY, D.; AL-REFAI, T. Behaviour of fabric versus fibre-reinforced sand. Journal of Geotechnical Engineering, ASCE, v. 112, n. 8, p. 804-826, 1986.

GRAY, D.; MAHER, M. Admixture stabilization of sand with discrete randomly distributed fibers. In: Proceedings of XII international conference on soil mechanics and foundation engineering, Rio de Janeiro, Brazil. [S.I.: s.n.], 1989. v. 2, p. 1363-1366.

GRAY, D.; OHASHI, H. Mechanics of fiber reinforcement in sand. Journal of Geotechnical Engineering, American Society of Civil Engineers, v. 109, n. 3, p. 335-353, 1983.

HANNANT, L. Polymers and polymers composities. Construction materials: their nature and behavior. 2ed., JM Illston/E \& FN Spon, p. 359-403, 1994.

HEAD, K. Manual of soil laboratory testing: Effective stress tests. [S.I.]: John Wiley \& Sons, USA, 1998. 227 p.

HEINECK, K. et al. Comportamento de solos micro-reforçados a pequeníssimas e grandes deformações cisalhantes. Solos e Rochas. São Paulo-SP, ABMS/ABGE, v. 26, n. 1, p. 3-17, 2003.

HEINECK, K. S. Estudo do comportamento hidráulico e mecânico de materiais geotécnicos para barreiras impermeáveis horizontais. Tese (Doutorado) PPGEC/UFRGS, Porto Alegre, 2002.

HEINECK, K. S.; COOP, M. R.; CONSOLI, N. C. Effect of microreinforcement of soils from very small to large shear strains. Journal of geotechnical and geoenvironmental engineering, American Society of Civil Engineers, v. 131, n. 8, p. 1024-1033, 2005.

HEJAZI, S. et al. A simple review of soil reinforcement by using natural and synthetic fibers. Construction and building materials, Elsevier, v. 30, p. 100-116, 2012. 
HOARE, D. Laboratory study of granular soils reinforced with randomly oriented discrete fibers. In: Proceedings of the International Conference on Soil Reinforcement. [S.I.: s.n.], 1979. v. 1, p. 47-52.

IBRAIM, E. et al. Assessment of laboratory sample preparation for fibre reinforced sands. Geotextiles and Geomembranes, Elsevier, v. 34, p. 69-79, 2012.

IBRAIM, E. et al. Static liquefaction of fibre reinforced sand under monotonic loading. Geotextiles and Geomembranes, Elsevier, v. 28, n. 4, p. 374-385, 2010.

ISAAC, S. R.; NAIR, M. A. Biodegradation of leaf litter in the warm humid tropics of kerala, india. Soil Biology and Biochemistry, Elsevier, v. 37, n. 9, p. 1656-1664, 2005.

JAMEI, M.; VILLARD, P.; GUIRAS, H. Shear failure criterion based on experimental and modeling results for fiber-reinforced clay. International Journal of Geomechanics, ASCE, v. 13, n. 6, p. 882-893, 2013.

JOHN, M. J.; ANANDJIWALA, R. D. Recent developments in chemical modification and characterization of natural fiber-reinforced composites. Polymer composites, Wiley Online Library, v. 29, n. 2, p. 187-207, 2008.

JOHNSTON, C. Advances in Concrete Technology. [S.I.]: Ottawa: National Resources Canada) Fiber-Reinforced Cement and Concrete, 1994.

JOSEPH, K.; MEDEIROS, E. S.; CARVALHO, L. H. Compósitos de matriz poliéster reforçados por fibras curtas de sisal. Polímeros: Ciência e Tecnologia, v. 9, n. 4 , p. 136-141, 1999.

JOY, S. et al. Biodegradation of coir geotextile in tropical climatic conditions. In: Proceedings of the golden jubilee Indian geotechnical conference, Kochi, India. [S.I.: s.n.], 2011. p. 604-606.

KANIRAJ, S. R.; HAVANAGI, V. G. Behavior of cement-stabilized fiber-reinforced fly ash-soil mixtures. Journal of geotechnical and geoenvironmental engineering, American Society of Civil Engineers, v. 127, n. 7, p. 574-584, 2001.

KAUL, R. The influence of roots on certain mechanical properties of an uncompacted soil. Tese (Ph.D. dissertation) - University of North Carolina, North Carolina, 1965.

KUGAN, R.; SARSBY, R. In-soil biodegradation of palm mat geotextiles. Land Degradation \& Development, Wiley Online Library, v. 22, n. 5, p. 463-471, 2011.

LEKHA, B.; GOUTHAM, S.; SHANKAR, A. Evaluation of lateritic soil stabilized with arecanut coir for low volume pavements. Transportation Geotechnics, Elsevier, v. 2, p. 20-29, 2015.

LEOCáDIO, G. Reforço de solo laterítico com fibras de sisal de distribuição aleatória, tratadas superficialmente com EPS reciclado. Dissertação (Mestrado) — Universidade Federal de Ouro Preto. Escola de Minas., 2005. 
LIRER, S.; FLORA, A.; CONSOLI, N. C. Experimental evidences of the effect of fibres in reinforcing a sandy gravel. Geotechnical and Geological Engineering, Springer, v. 30, n. 1, p. 75-83, 2012.

LOUZADA, N. S. Experimental Study of Soils Reinforced with Crushed Polyethylene Terephthalate (PET) Residue. Dissertação (Mestrado) - Pontifícia Universidade Católica do Rio de Janeiro, Rio de Janeiro, 2015.

MAHER, M.; GRAY, D. Static response of sands reinforced with randomly distributed fibers. Journal of Geotechnical Engineering, ASCE, v. 116, n. 11, p. 1661-1677, 1990.

MAHER, M.; HO, Y. Mechanical properties of kaolinite/fiber soil composite. Journal of Geotechnical Engineering, American Society of Civil Engineers, v. 120, n. 8, p. 1381-1393, 1994.

MARTINS, A. Desenvolvimento, caracterização mecânica e durabilidade de compósitos solo-cimento autoadensáveis reforçados com fibras de sisal. Tese (Doutorado) - UFRJ/COPPE. Rio de Janeiro, 2014.

MATTOSO, L.; FERREIRA, F.; CURVELO, A. Sisal fiber: morphology and applications in polymer composites. In: international symposium on. [S.I.: s.n.], 1997.

MCGOWN, A.; ANDRAWES, K.; AL-HASANI, M. Effect of inclusion properties on the behaviour of sand. Geotechnique, Thomas Telford Ltd, v. 28, n. 3, p. 327-346, 1978.

MCGOWN, A. et al. Soil strengthening using randomly distributed mesh elements. In: International Conference on Soil Mechanics and Foundation Engineering. [S.I.: s.n.], 1985. v. 11, p. 1735-1738.

MELO FILHO, J. A. Durabilidade Química e Térmica e Comportamento Mecânico de Compósitos de Alto Desempenho Reforçados com Fibras de Sisal. Tese (Doutorado) - PEC/COPPE/UFRJ, Rio de Janeiro, 2012.

METHACANON, P. et al. Properties and potential application of the selected natural fibers as limited life geotextiles. Carbohydrate Polymers, Elsevier Ltd., v. 82, p. 1090-1096, 2010.

MICHALOWSKI, R. L.; ČERMÁK, J. Triaxial compression of sand reinforced with fibers. Journal of geotechnical and geoenvironmental engineering, American Society of Civil Engineers, v. 129, n. 2, p. 125-136, 2003.

MIRZABABAEI, M. et al. Unconfined compression strength of reinforced clays with carpet waste fibers. Journal of Geotechnical and Geoenvironmental Engineering, v. 139, n. 3, p. 483-493, 2013.

MOHANTY, A. K.; MISRA, M.; DRZAL, L. T. Natural fibers, biopolymers, and biocomposites. [S.I.]: CRC press, 2005.

MONTARDO, J. Comportamento mecânico de compósitos solo-cimento-fibra: estudo do efeito das propriedades dos materiais constituintes. Dissertação (Mestrado) - CPGEC/UFRGS, Porto Alegre, 1999. 
MONTARDO, J. P.; CONSOLI, N. C.; PRIETTO, P. D. M. Comportamento mecânico de compósitos solo-cimento-fibra: Estudo do efeito das propriedades dos materiais constituintes. Revista Solos e Rochas, São Paulo, v. 24, n. 3, p. 191-209, 2002.

MOREIRA, F. d. S. Microbiologia e bioquímica do solo. [S.I.]: Ufla, 2006.

MOREL, J.; GOURC, J. Mechanical behavior of sand reinforced with mesh elements. Geosynthetics International, Thomas Telford Ltd, v. 4, n. 5, p. 481-508, 1997.

NATARAJ, M.; ADDULA, H.; MCMANIS, K. Strength and deformation characteristics of fiber reinforced soils. In: International Symposium on Environmental Geotechnology. [S.I.: s.n.], 1996. v. 3, p. 826-835.

OLIVEIRA, A. F. d. Avaliação de desempenho de fibras lignocelulósicas na sorção de óleos diesel e biodiesel. Tese (Doutorado), 2010.

OTOKO, G.; EPHRIAM, M.; IKEGBOMA, A. Reinforcement of a lateritic soil using oil palm fruit fibre. International Journal Of Engineering and Technology Research, v. 2, n. 6, p. 1-5, 2014.

PALACIOS, M. Comportamento de uma Areia Reforçada com Fibras de Polipropileno Submetida a Ensaios Triaxiais de Extensão. Dissertação (Dissertação de Mestrado) - Pontifícia Universidade Católica do Rio de Janeiro, Rio de Janeiro, 2012.

PALMEIRA, E. Geossintéticos: tipos e evolução nos últimos anos. In: SÃO PAULO: ASSOCIAÇÃO BRASILEIRA DE MECÂNICA DOS SOLOS E ENGENHARIA GEOTÉCNICA. $1^{\circ}$ Simpósio Brasileiro Sobre Geossintéticos - Geossintéticos'92. Brasília, 1992. p. 1-20.

PERISSOTTO, D. Estudo Comparativo das Propriedades Químicas de Polpas Kraft Convencionais e MCC de Eucalipto. Tese (Doutorado) - Universidade Federal do Paraná, Curitiba, 2005.

PESSOA, F. Análises dos solos de Urucu para fins de uso rodoviário. Dissertação (Dissertação de Mestrado em Geotecnia) - Faculdade de Tecnologia Universidade de Brasília, Brasília-DF, 2004.

PICANÇO, M. d. S. Compósitos cimentícios reforçados com fibras de curauá. 2005. Dissertação (Mestrado) - Centro Técnico Científico, Pontifícia Universidade Católica do Rio de Janeiro, Rio de Janeiro, 2005.

PINTO, A. R. A. G. Fibras de curauá e sisal como reforço em matrizes de solo. Dissertação (Mestrado) - Departamento de Engenharia Civil, Pontifícia Universidade Católica do Rio de Janeiro, 2007.

PLÉ, O.; LÊ, H.; GOTTELAND, P. A mechanical approach for fibre-reinforced clay in landfill caps cover application. European Journal of Environmental and Civil Engineering, Taylor \& Francis, v. 13, n. 1, p. 53-69, 2009. 
POPESCU, M.-C. et al. Evaluation of morphological and chemical aspects of different wood species by spectroscopy and thermal methods. Journal of Molecular Structure, Elsevier, v. 988, n. 1-3, p. 65-72, 2011.

PRABAKAR, J.; SRIDHAR, R. Effect of random inclusion of sisal fibre on strength behaviour of soil. Construction and Building Materials, Elsevier, v. 16, n. 2, p. 123-131, 2002.

QU, J.; SUN, Z. Strength behavior of shanghai clayey soil reinforced with wheat straw fibers. Geotechnical and Geological Engineering, Springer, v. 34, n. 2, p. 515-527, 2016.

RAMESH, H.; KRISHNA, K.; MAMATHA, H. Effect of lime-coir fiber on geotechnical properties of black cotton soil. In: Indian Geotechnical Conf.-2010. [S.I.: s.n.], 2010. p. 487-490.

RANJAN, G.; VASAN, R.; CHARAN, H. Probabilistic analysis of randomly distributed fiber-reinforced soil. Journal of Geotechnical Engineering, American Society of Civil Engineers, v. 122, n. 6, p. 419-426, 1996.

SAHA, P. et al. Durability of transesterified jute geotextiles. Geotextiles and Geomembranes, Elsevier, v. 35, p. 69-75, 2012.

SANTIAGO, G. A. Estudo do Comportamento Mecânico de Compósitos Solo-Fibras Vegetais Impermeabilizadas com Solução de Poliestireno Expandido (EPS) e Cimento Asfáltico de Petróleo (CAP). Tese (Doutorado) - Universidade Federal de Ouro Preto. Escola de Minas, 2011.

SANTONI, R. L.; TINGLE, J. S.; WEBSTER, S. L. Engineering properties of sand-fiber mixtures for road construction. Journal of geotechnical and geoenvironmental engineering, American Society of Civil Engineers, v. 127, n. 3, p. 258-268, 2001.

SANTOS, P. A. et al. Efeito da forma de processamento e do tratamento da fibra de curauá nas propriedades de compósitos com poliamida-6. Polímeros: Ciência e tecnologia, Associação Brasileira de Polímeros, v. 19, n. 1, 2009.

SARBAZ, H.; GHIASSIAN, H.; HESHMATI, A. A. Cbr strength of reinforced soil with natural fibres and considering environmental conditions. International Journal of Pavement Engineering, Taylor \& Francis, v. 15, n. 7, p. 577-583, 2014.

SARKANEN, K. V.; LUDWIG, C. H. Liguins. Occurrence, formation, structure, and reactions. [S.I.]: New York.; Wiley-Interscience, 1971.

SARSBY, R. Vegetable fibre geotextiles. In: Presentation to the Ministry of Agriculture, Fisheries and Food. [S.I.: s.n.], 1997.

SARSBY, R. W. Use of 'limited life geotextiles'(Ilgs) for basal reinforcement of embankments built on soft clay. Geotextiles and Geomembranes, Elsevier, v. 25, n. 4-5, p. 302-310, 2007.

SEGAL, L. et al. An empirical method for estimating the degree of crystallinity of native cellulose using the $x$-ray diffractometer. Textile Research Journal, Sage Publications Sage CA: Thousand Oaks, CA, v. 29, n. 10, p. 786-794, 1959. 
SENEZ, P. C. Comportamento de uma Areia Reforçada com Fibras de Polietileno Tereftalato (PET). Dissertação (Mestrado) - PUC-Rio, 2016.

SHEWBRIDGE, S. E.; SITAR, N. Deformation-based model for reinforced sand. Journal of geotechnical engineering, American Society of Civil Engineers, v. 116, n. 7, p. 1153-1170, 1990.

SILVA, F. Durabilidade e Propriedades Mecânicas de Compósitos Cimentícios Reforçados por Fibras de Sisal. Tese (Tese de Doutorado em Engenharia Civil) COPPE - Universidade Federal do Rio de Janeiro, Rio de Janeiro, 2009.

SILVA, F. d. A.; CHAWLA, N.; TOLÊDO FILHO, R. D. Mechanical behavior of natural sisal fibers. Journal of Biobased Materials and Bioenergy, American Scientific Publishers, v. 4, n. 2, p. 106-113, 2010.

SILVA, O. R. R. F. et al. Cultivo do sisal no nordeste brasileiro. Embrapa Algodão. Circular Técnica, Campina Grande: Embrapa Algodão, 2008.

SIVAKUMAR BABU, G.; VASUDEVAN, A. Evaluation of strength and stiffness response of coir-fibre-reinforced soil. Proceedings of the Institution of Civil Engineers-Ground Improvement, Thomas Telford Ltd, v. 11, n. 3, p. 111-116, 2007.

SOTOMAYOR, J. Avaliação do comportamento carga-recalque de uma areia reforçada com fibra de coco submetida a ensaios de placa em verdadeira grandeza. Dissertação (Dissertação de Mestrado em Geotecnia) - Pontifícia Universidade Católica do Rio de Janeiro, Rio de Janeiro, 2014.

SPECHT, L. Comportamento de misturas de solo-cimento-fibra submetidos a carregamentos estáticos visando à pavimentação. Dissertação (Mestrado) Programa de Pós-Graduação em Engenharia Civil da UFRGS, Porto Alegre, 2000.

STAUFFER, S.; HOLTZ, R. Stress-strain and strength behavior of staple fiber and continuous filament-reinforced sand. Transportation research record, n. 1474, 1995.

TANG, C. et al. Strength and mechanical behavior of short polypropylene fiber reinforced and cement stabilized clayey soil. Geotextiles and Geomembranes, Elsevier, v. 25, n. 3, p. 194-202, 2007.

TAYLOR, G. D. Materials in construction. [S.I.]: Longman Scientific \& Technical, 1994.

TEODORO, J.; BUENO, B. Estudo do comportamento dos solos reforçados com fibras plásticas de polipropileno. In: Congresso Brasileiro de Mecânica dos Solos e Engenharia Geotécnica. [S.I.: s.n.], 1998. v. 11, p. 1093-1100.

TEODORO, J. M. Resistência ao cisalhamento de solos reforçados com fibras plásticas. Dissertação (Mestrado) - Escola de São Carlos/ USP, São Paulo, 1999.

THOMAS, S. et al. Natural fibres: structure, properties and applications. In: Cellulose fibers: bio-and nano-polymer composites. [S.I.]: Springer, 2011. p. 3-42. 
TOLÊDO FILHO, R. Materiais compósitos reforçados com fibras naturais: caracterização experimental. Tese (Doutorado) - Departamento de Engenharia Civil. Pontifícia Universidade Católica do Rio de Janeiro, 1997.

TOMCZAK, F. Estudos sobre a estrutura e propriedades de fibras de coco e curauá do Brasil. Tese (Doutorado) — Universidade Federal do Paraná, 2011.

TOMCZAK, F.; SATYANARAYANA, K. G.; SYDENSTRICKER, T. H. D. Studies on lignocellulosic fibers of brazil: Part iii-morphology and properties of brazilian curauá fibers. Composites Part A: Applied Science and Manufacturing, Elsevier, v. 38, n. 10, p. $2227-2236,2007$.

ULBRICH, L. Aspectos do comportamento mecânico de um solo reforçado com fibras. Porto Alegre, 1997. 122p. Tese (Doutorado) - Dissertação (Mestrado em Engenharia)-Programa de Pós-Graduação em Engenharia Civil da UFRGS, 1997.

VAN IMPE, W. Soil improvement techniques and their evolution. [S.I.]: CRC Press, 1989.

VENDRUSCOLO, M. Comportamento de ensaios de placa em camadas de solo melhoradas com cimento e fibras de polipropileno. Tese (Doutorado) - Programa de Pós-Graduação em Engenharia Civil da UFRGS, Porto Alegre, 2003.

VENKATAPPA RAO, G. Coir geotextiles, strategic management initiatives. In: Proc. International. [S.I.: s.n.], 2002.

VIDAL, H. The principle of reinforced earth. Highway Research Record, n. 282, 1969.

YANG, H. et al. Characteristics of hemicellulose, cellulose and lignin pyrolysis.

Fuel, Elsevier, v. 86, n. 12-13, p. 1781-1788, 2007. 